

$$
\text { دولت انتقالي اسلامي }
$$

$$
\begin{aligned}
& \text { ماهنامه } \\
& \text { شماره Y- } 1 \\
& \text { ميزان- عقرب } \\
& \text { ए人 }
\end{aligned}
$$



$$
\text { حقوقي - قضائي }
$$




























قضا و قضاوت درعهل سلطنت اعليحضرت محمد ظاهر شاه




















حقوق سياسي محكوم نشده باشند


استنياف سن سي را تكميل كرده باشند.












هـ با مراض ساري و به امراضيكه مانع اجراي وظيفه قضا تُدد مصاب نباشند .


در دست داشته باشد . مان. در باب سوم قانون صلاحيت و تشكيلات قضائي دولت شاهي افغانستان نافذه


تصريحاتي بعمل آمده است : مادو : ماده ( مY) : قضات براي بار اول بفرمان بادشاهي دركدر قضا تعيين ميشوند .


باشند: اــ اقلا ده سال قبل از تعيين به وظيفه قضا تابعيت افغاني راحاصل كرده باشند. r- بعد از تاريخ و ميزان باسبا هجري شمسي در اثر فيصله قطعي محكمه بحرمان از حقوق سياسي محكوم نشده باشند






مدارس رسمي شرعي دولت را كه يائين تر از سويه بكلوريا نباشد دارا باشند . هـ به امراض ساري و به امراضيكه مانع اجراي وظيفه قضا تزدد مصاب نباشند .


عسكري در دست داشته باشند














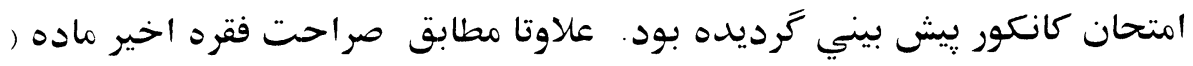

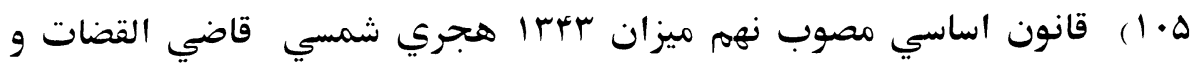

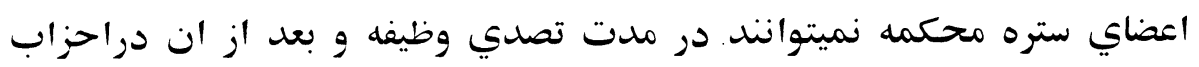
سياسي شموليت ورزند. ناعفته نبايد تذاشت كه مقررات مربوط به امتحان براي استخدام قضات واعضاي

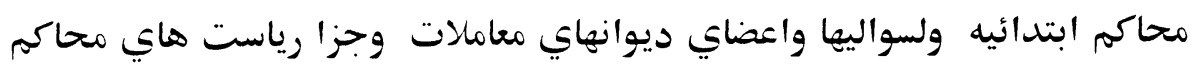

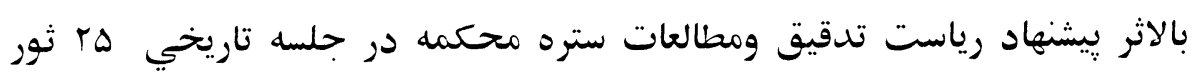

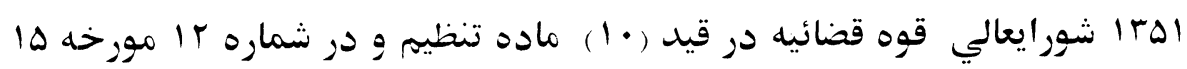

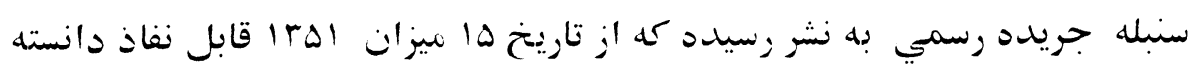
شده

ماده اول مقررات متذكره مشعر است كه بموجب فقرة : جيارم ماده (DV) قانون

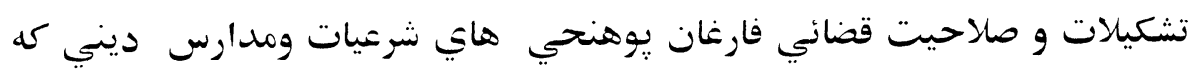



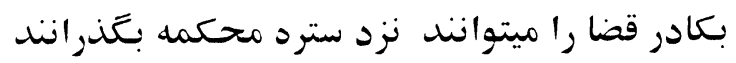

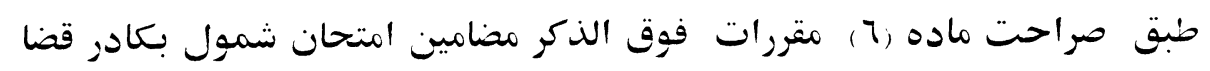




ب : قوانين مدونه ( قانون اساسي ، قانون تشكيلات وصاحيت قضائي . قانون






واحصائيه اراضي و ساير قوانين كه امتحان آن از طرف آمريت عمومي إني اداري




ج: لوايح و مقررات مربوط به قضا ' دارئ



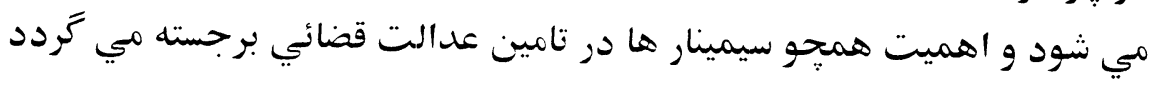
د : سيمينار هاي ستره محكمه

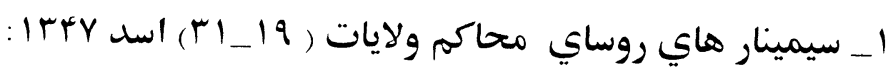

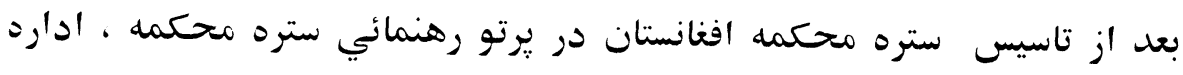

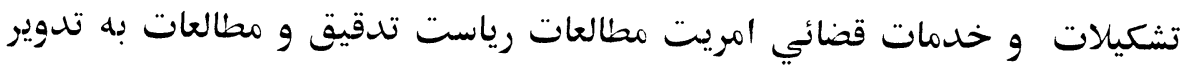

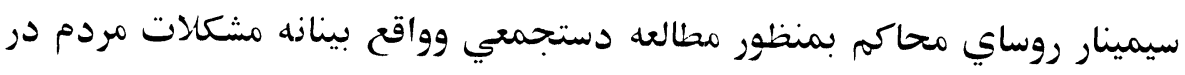

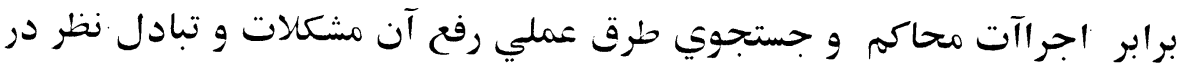

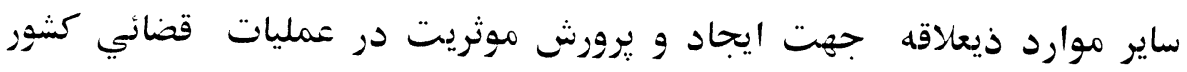
موظف ترديد

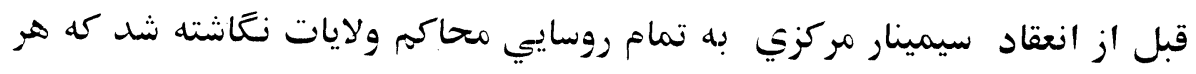

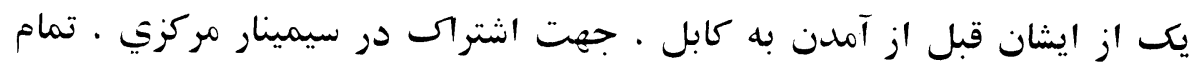

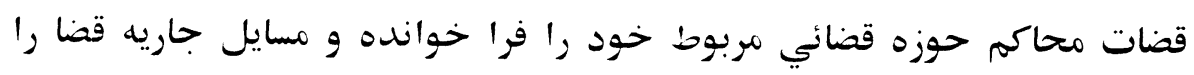

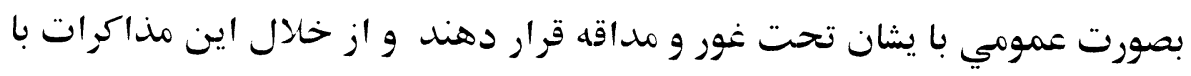

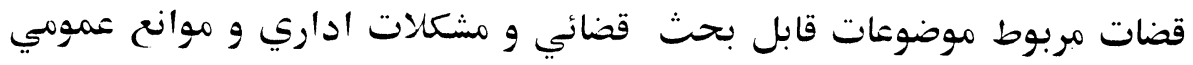

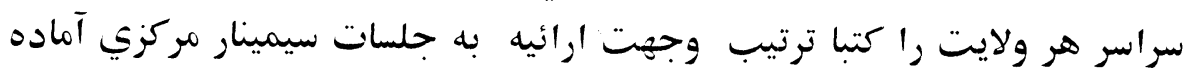
نمايند همجنين به رياست هائ محاكم ولايات الطلاع داده شد كه در سيمينار مركزي

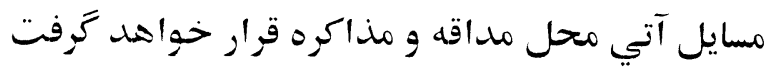

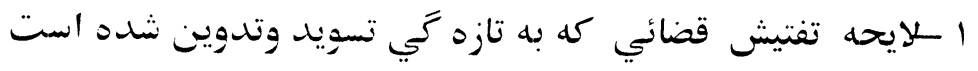

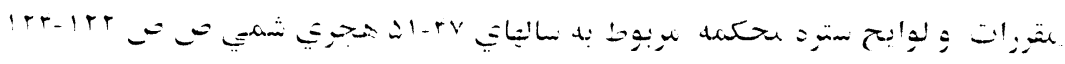




r اموضوع توحيد و تثبيت شكل و محتويات فيضله هاي ديوانهاي حقوق عامه، جزائي مامورين محاكم ولايات و ديوانهاي مربوط محكمه عالي استيناف مركزي

r مستوضيح مجدد متحدالمال هائيكه از شواريعالي به محاكم صادر شده است

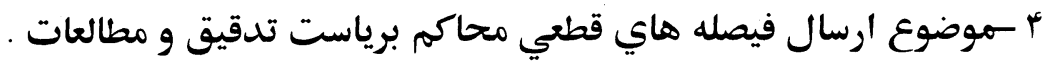

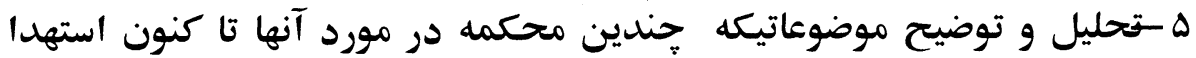

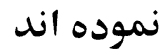

7 - 1 بحث در باره ساير مسايل و مشكلات محسوس محاكم ولايات كه از طرف

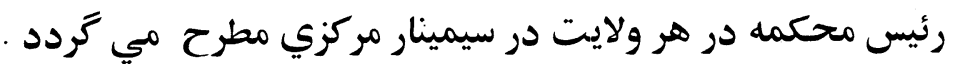

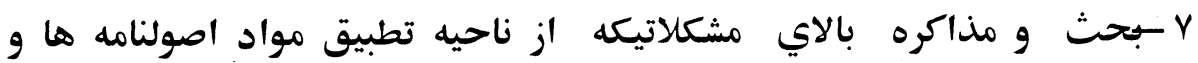

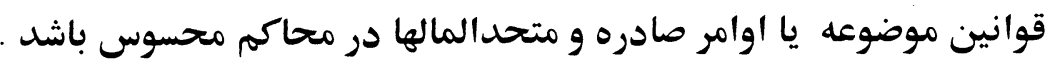

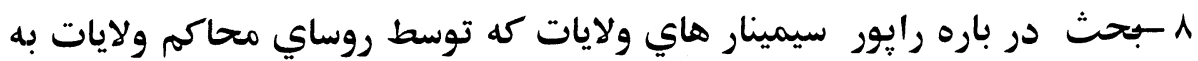
سيمينار مركزي ارائيه ميتردد.

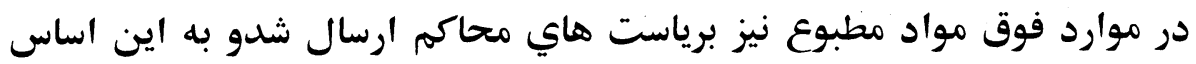

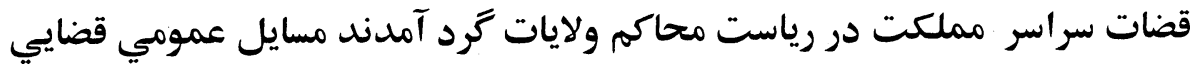

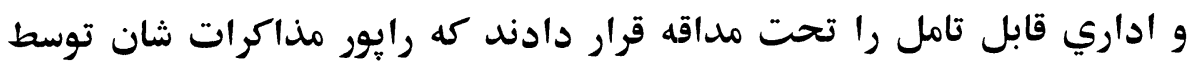

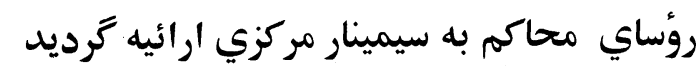

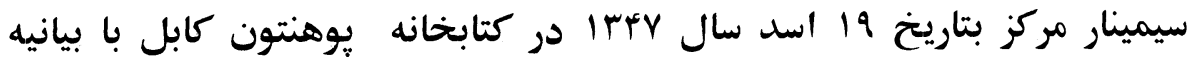

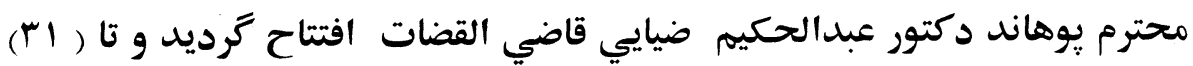
اسد دوام يافت

محترم ضيايي در اخير بيانيه افتتاحيه خويش اظهار داشت كه : ( بمنظور اينكه

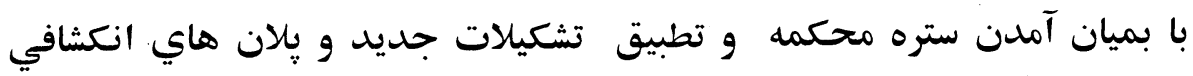






روساي محاكم ولايات كثور دعوت بعمل آمد تا در اولين سمينار روساي

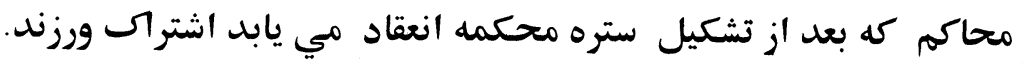

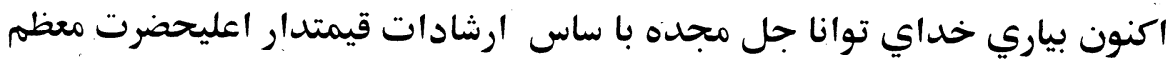

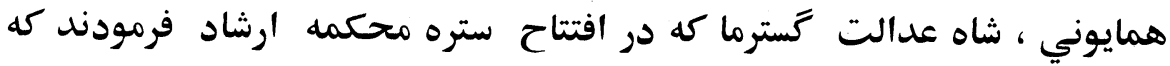

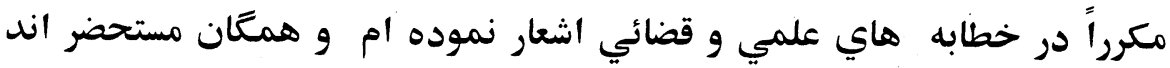

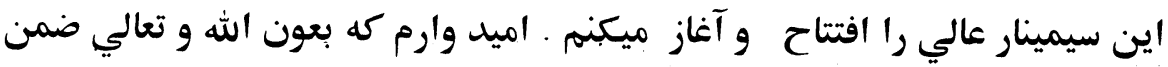

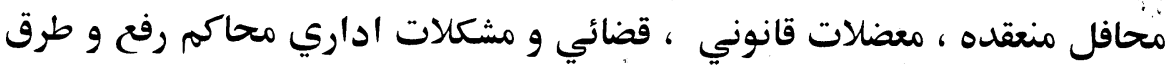

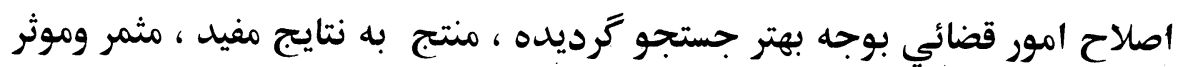

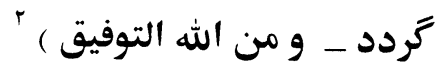

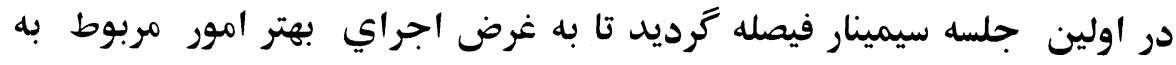

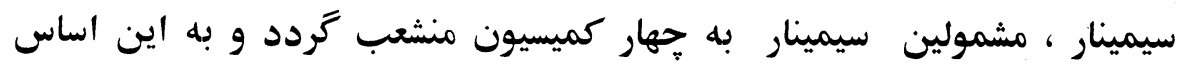

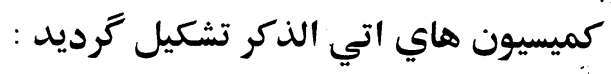

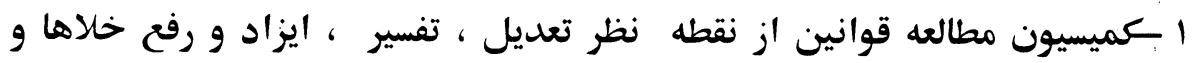
مشكلات تطبيقي قوانين

r r rميسيون مطالعه طرح لايحه تفتيش قضائي ومسايل مربوط به محصولات

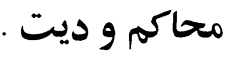
r r كمميسيون سوم در مورد توحيد و تثبيت شعل و محتويات فيصله ديوان هاي

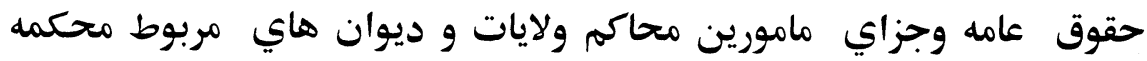

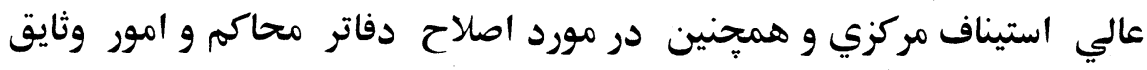
و اتخاذ تدابير موثر و جدي براي سرعت عمل قضائي و فراهم ساختن تسهيلات

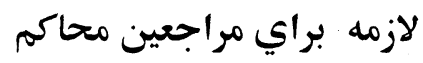

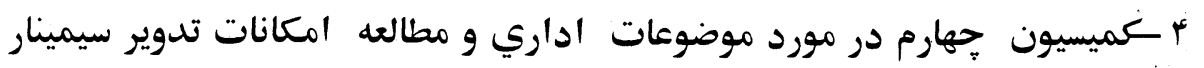
هاي آينده

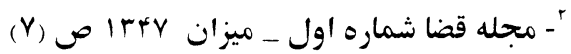

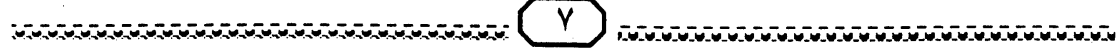


در سيمينار مطرح بحث بتعداد ( 119 ) مسايل و مشكنلات مورد غور و مداقه قرار

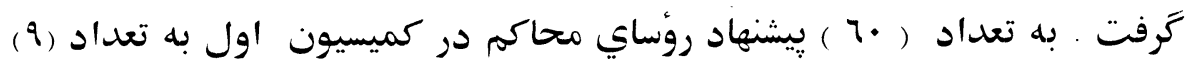

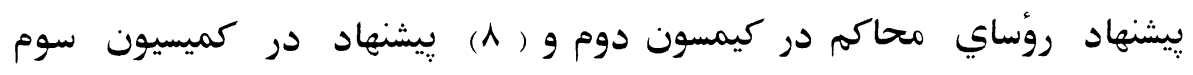

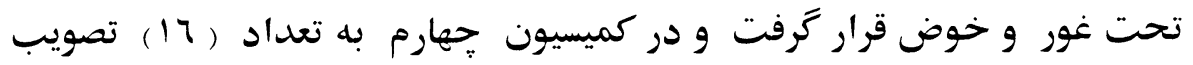

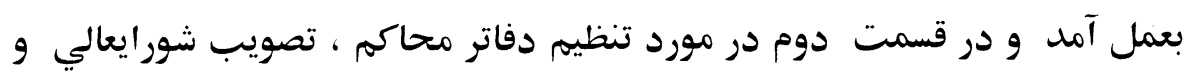

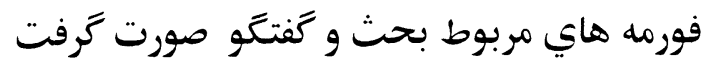

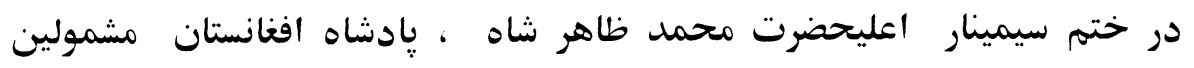

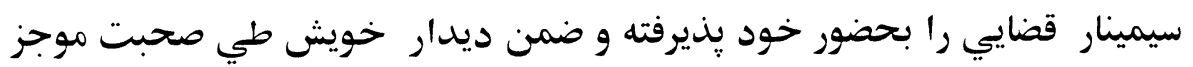

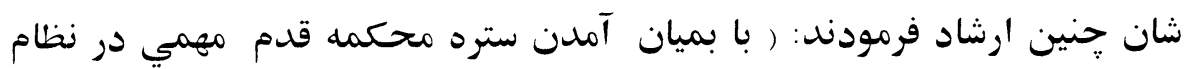

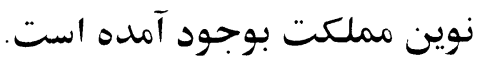

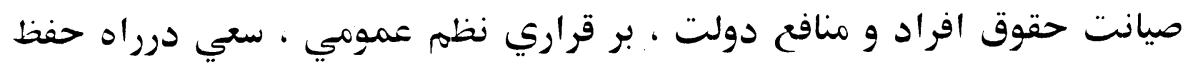

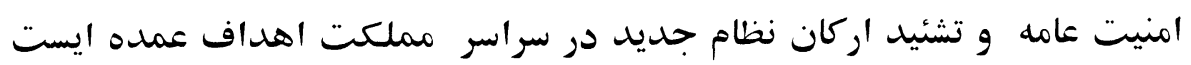

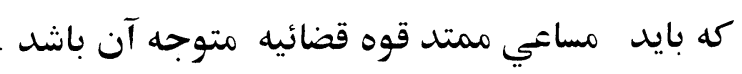

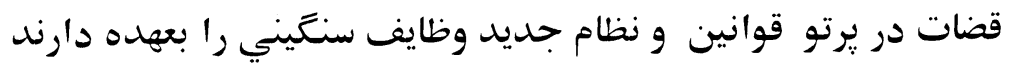

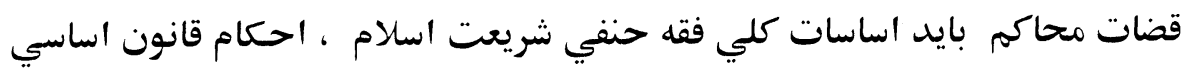

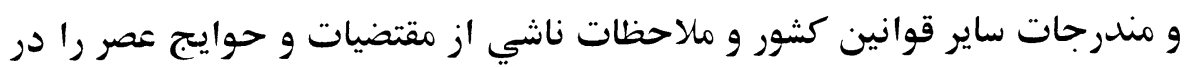

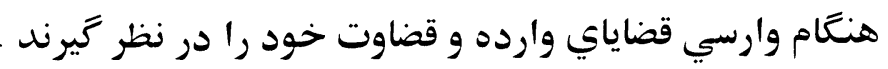

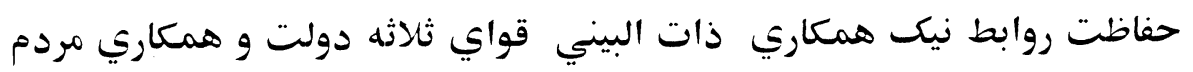

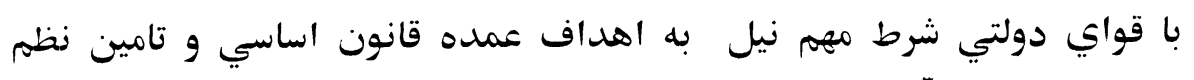

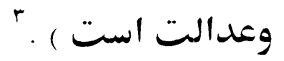

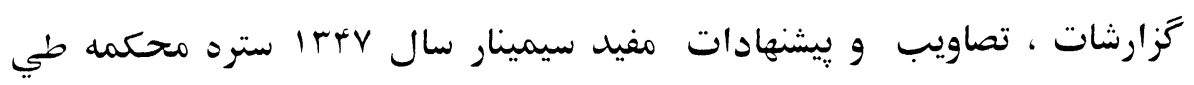

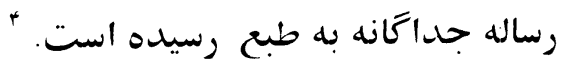

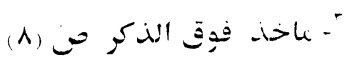

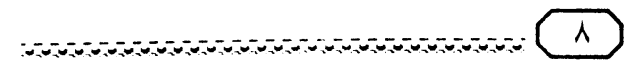


- سيمينار روساء و قضات محاكم تجارتي

( )

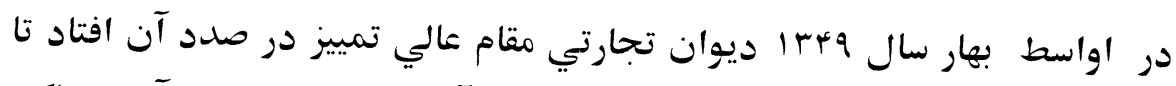

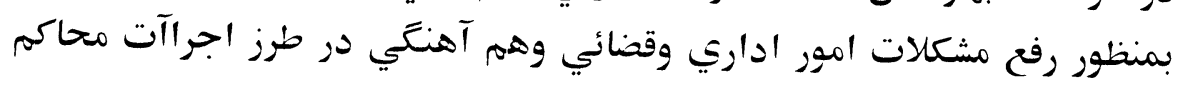

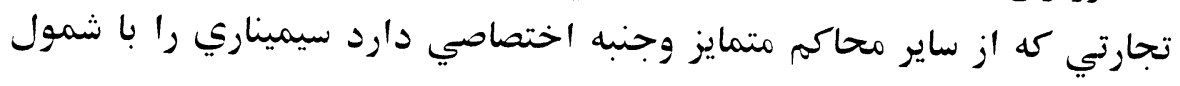

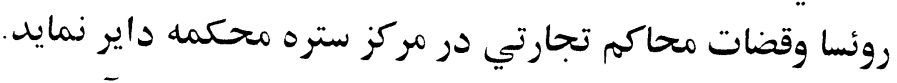

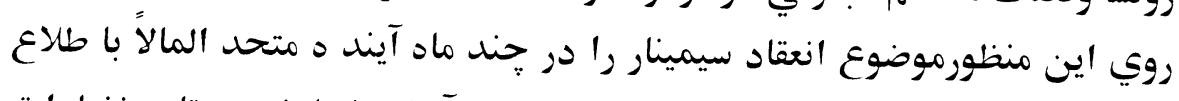

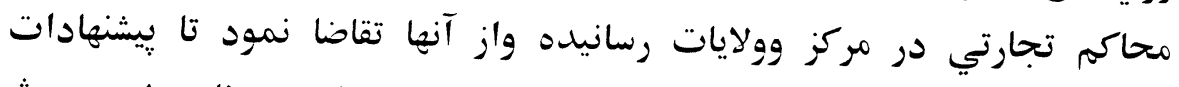

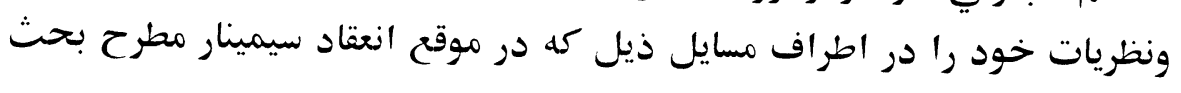

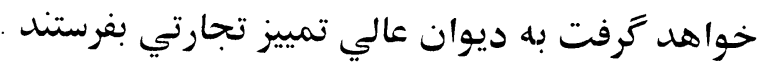

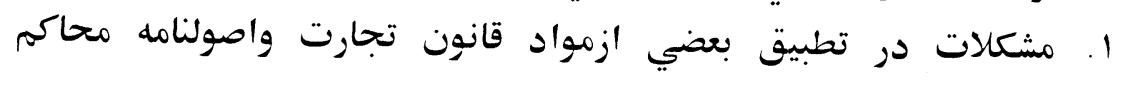

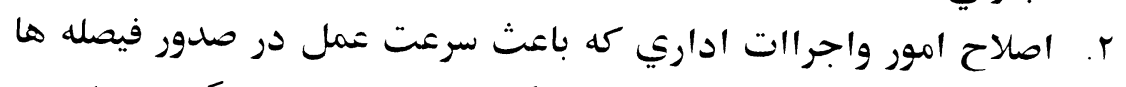

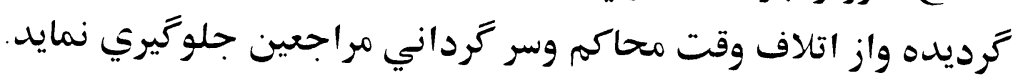

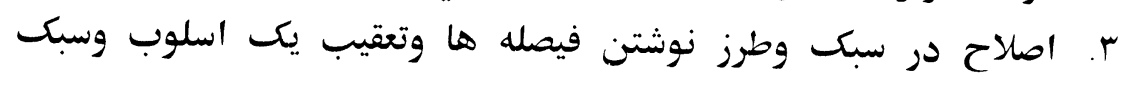

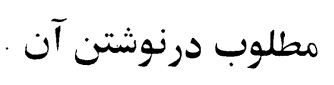

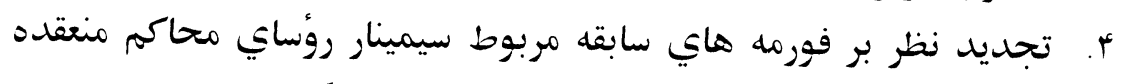

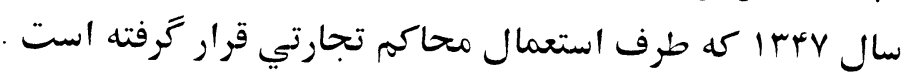

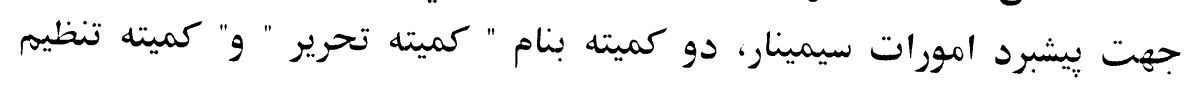

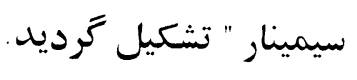

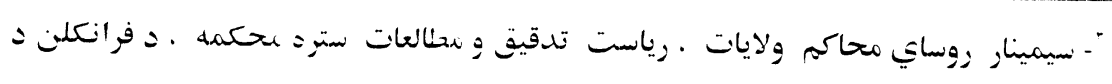

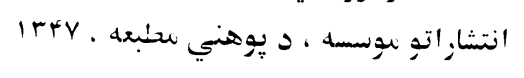

(9) 
كميته اولي كه عبارت از كميته تحرير باشد موظف ترديدتا مشكلات ونظر يات

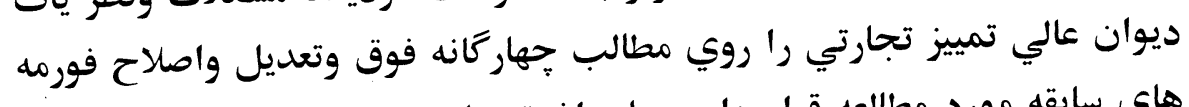

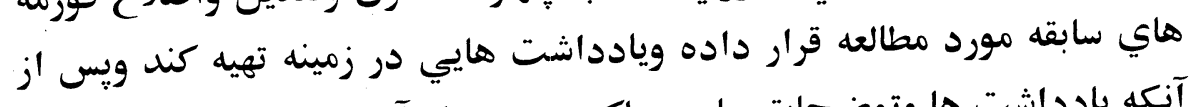



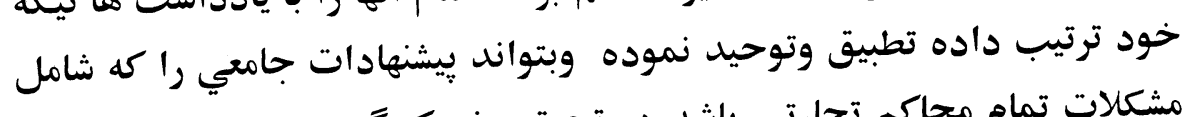

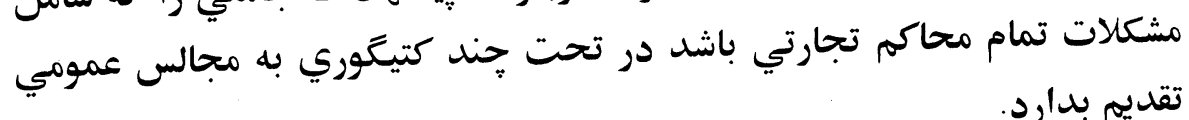
تقديم بدارد.

كميته دومي نيز موظف ترديدتا در تهيه محل مناسب براي سيمينار وتدارك تورى

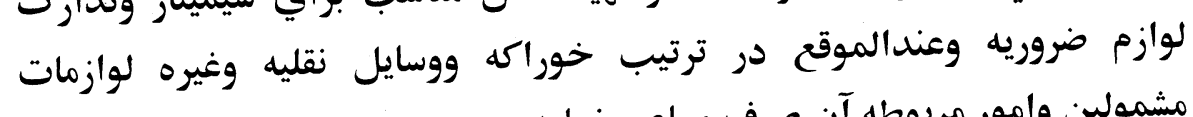

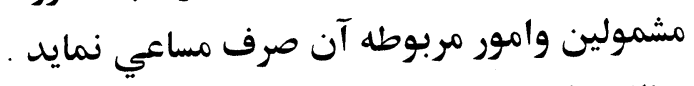

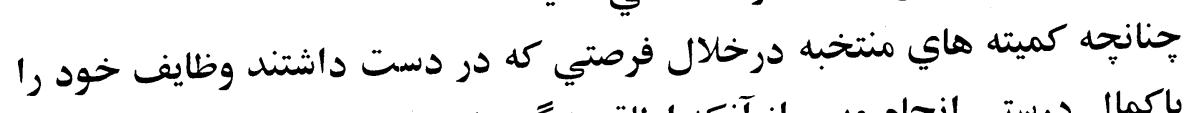

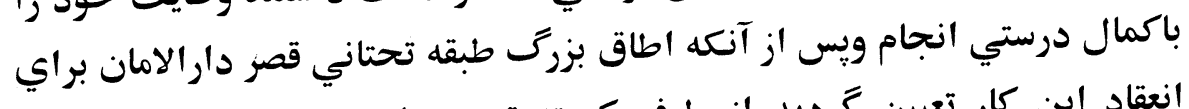

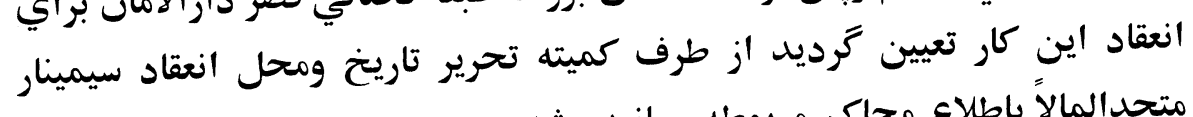

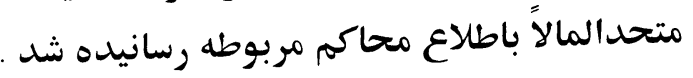

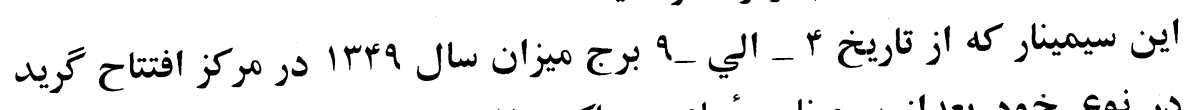

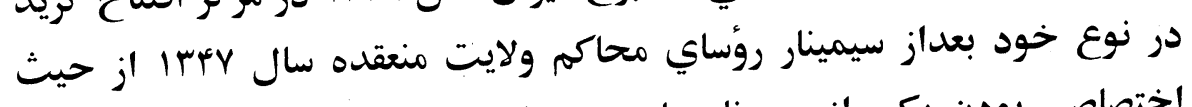

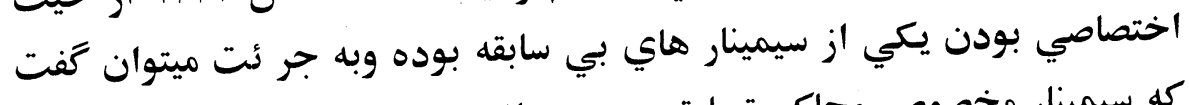

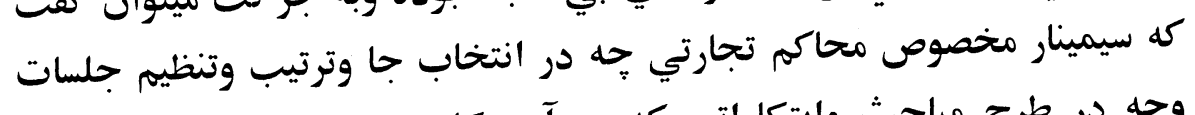

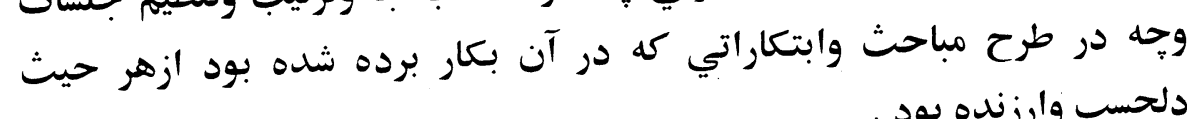

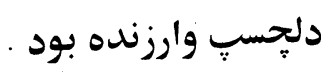
در موقع انعقاد سيمينار قضات محاكم تجارتي ، جناب يوهاند دوكتور عبدالحكيم

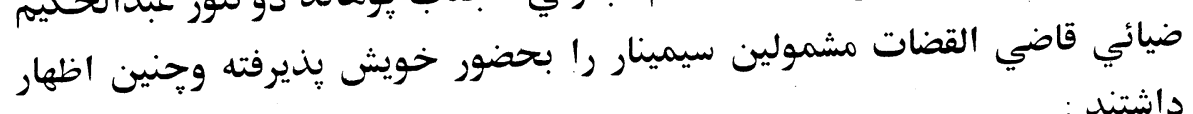
داشتند : 


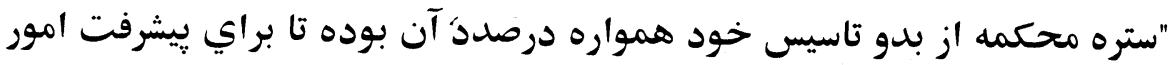

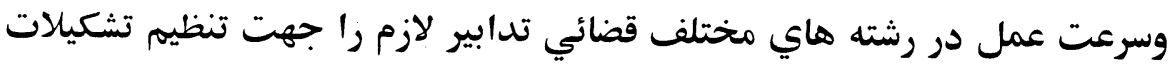

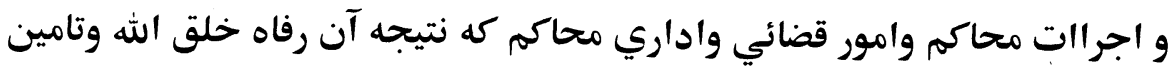

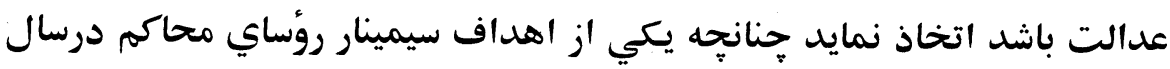

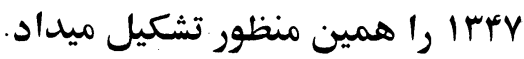

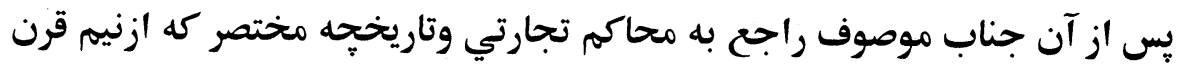

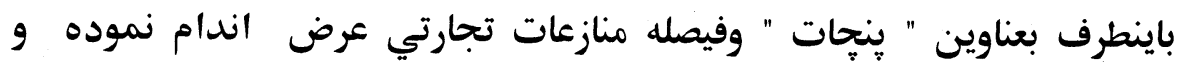

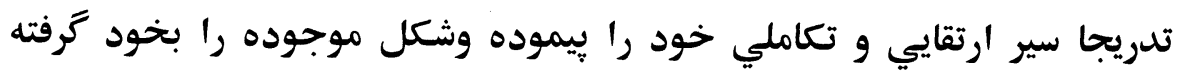

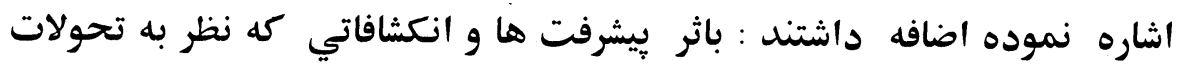

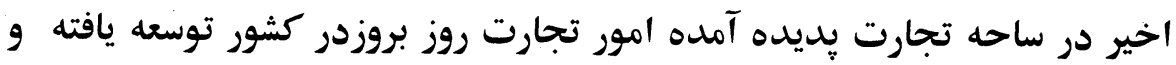

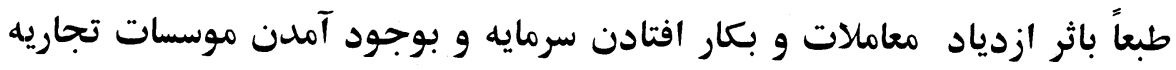

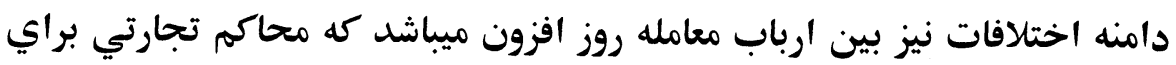

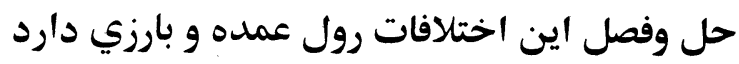

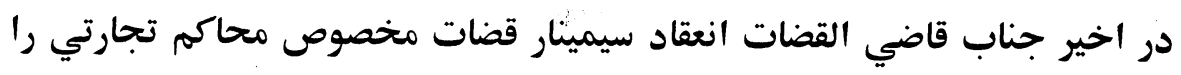

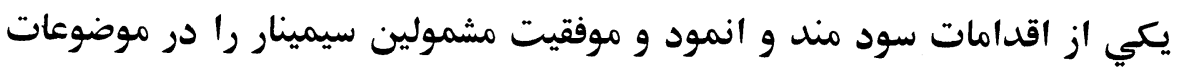

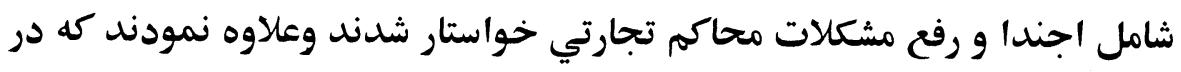

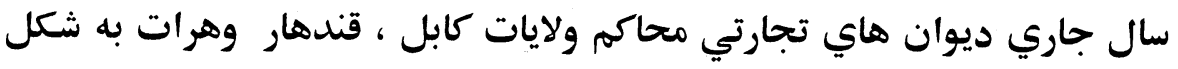

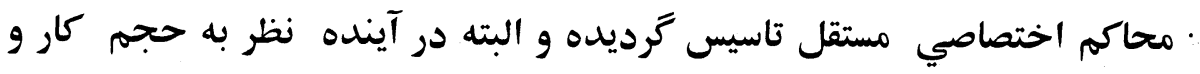

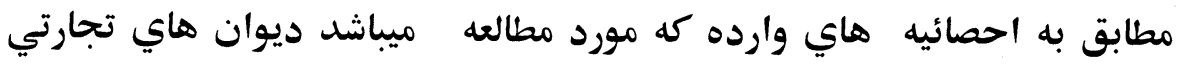

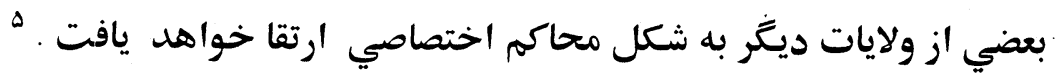

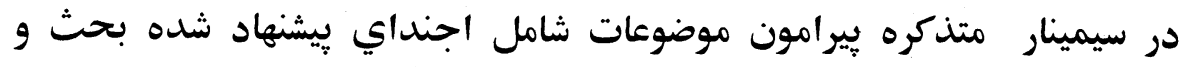

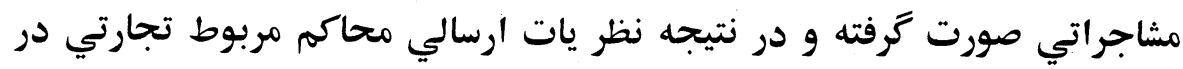

هـ سيمينار روسا و قضات محاكم تجارتي ، از نشرات ستره محكمه د فرانكلين د انتشاراتو موسسه

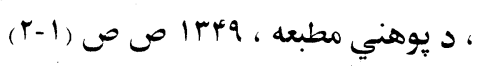

(11) 
مورد سيمينار تحت غور و مداقه قرار ترفت و به نظريات جواب طلب ياسخ

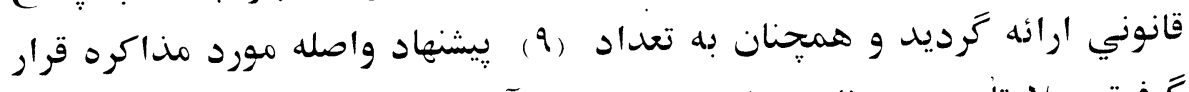

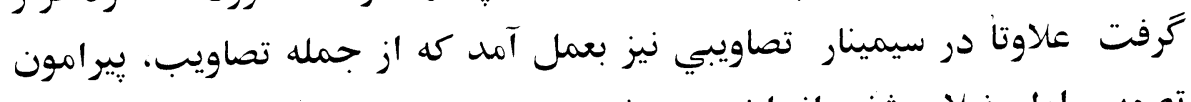

$$
\text { 1 تصويب اول ذيلا روشني انداخته مي شود : }
$$

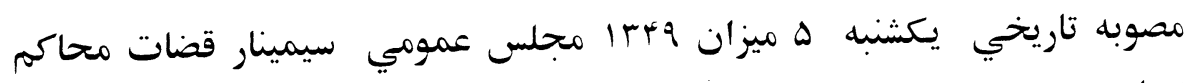

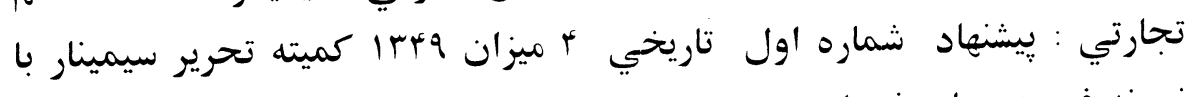

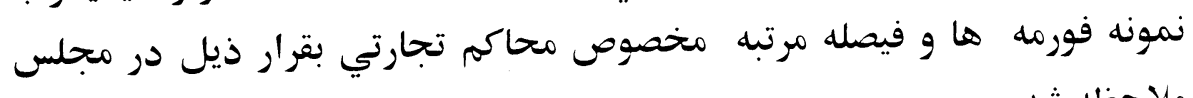
ملاحظه شد

$$
\begin{aligned}
& \text { اول } \\
& \text { دوم } \\
& \text { سوم } \\
& \text { r ب مورومه دفتر اجنداي جلسات } \\
& \text { جهارم } \\
& \text { ينجم } \\
& \text { ششم } \\
& \text { هفتم } \\
& \text { ا سفورومه اقامه دتوي در محكممه ابتدائيه } \\
& \text { هشتم } \\
& \text { نهم } \\
& \text { دهم } \\
& \text { r بوفتر اندراج }
\end{aligned}
$$

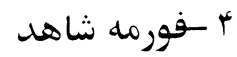

$$
\begin{aligned}
& \text { ه - افورمه فيصله جات محاكم ناهد }
\end{aligned}
$$

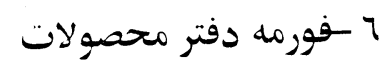

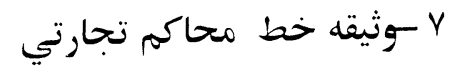

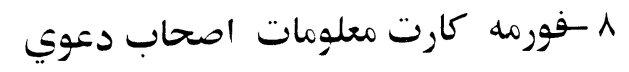

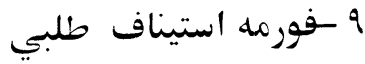

$$
\begin{aligned}
& \text { •ا اسفورمه تمييز طلبي }
\end{aligned}
$$


قرار شرح فوق در اطراف نمونه هاي فورمه ها از طرف مجلس عموني سيمينار

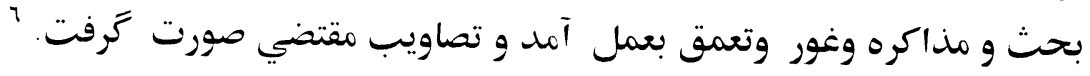

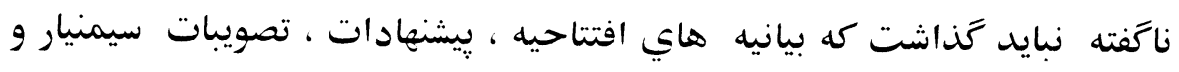

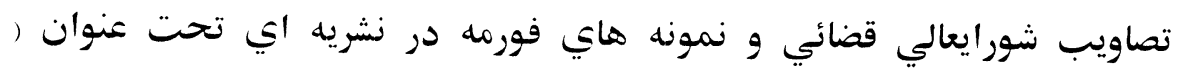

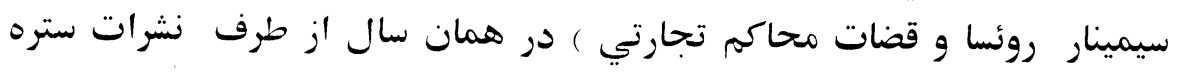

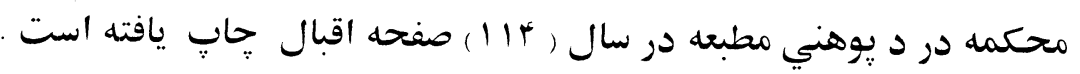

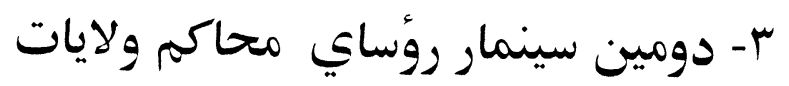

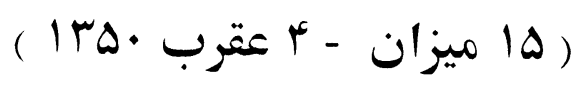

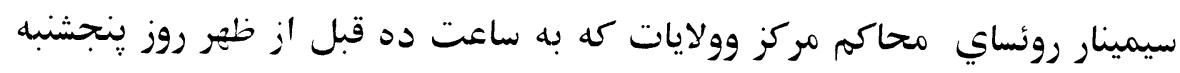

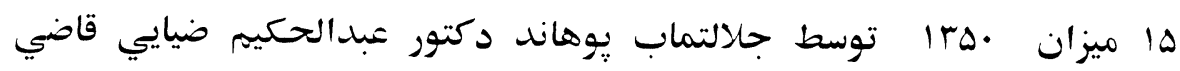

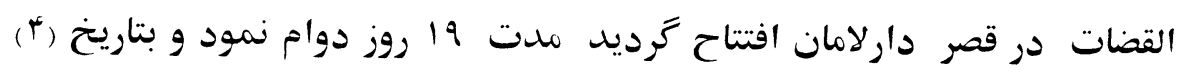

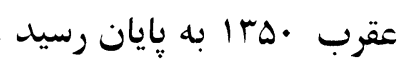

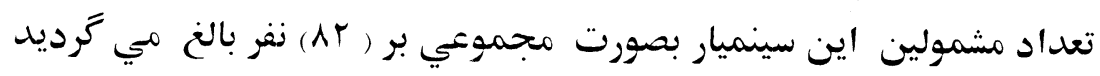

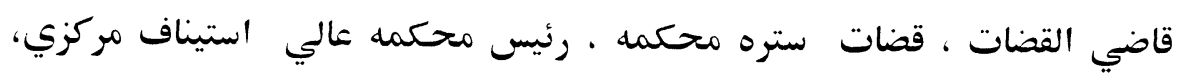

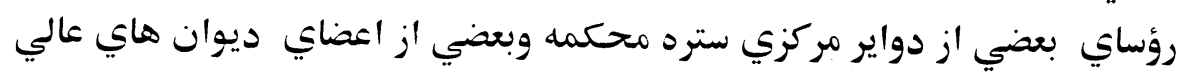

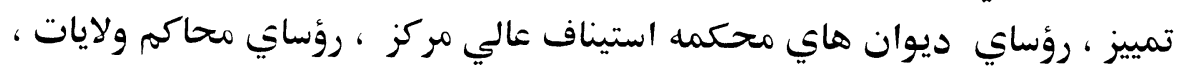



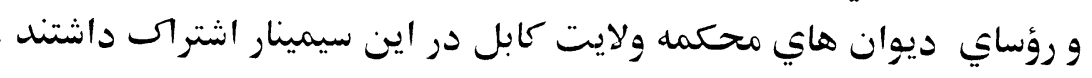

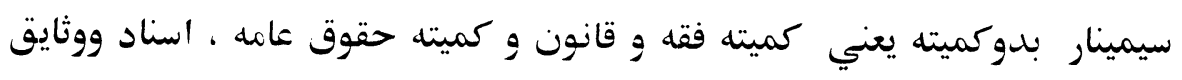

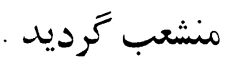
در كميته اول به تعداد ( ماح) فقره و و دركميته دوم ( وها فقره مطرح غور و مباحثه قراركرفت

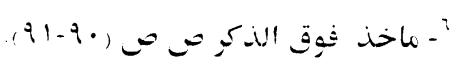


يوهاند دكتور عبدالحكيم ضيايى قاضى القضـات در بيانيسه اش بمناسـبت افتـاح

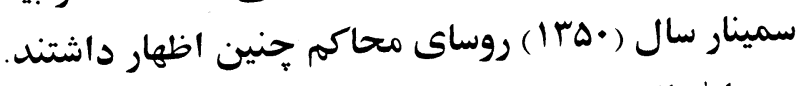

$$
\begin{aligned}
& \text { بسم اله الرحمن رحيم طالمان } \\
& \text { حضار محترم : حال الرحن }
\end{aligned}
$$

جاى مسرت است كه يكبار ديكر موقع مسـاعدت كـرد كسه تمـام روسـاى محساكم

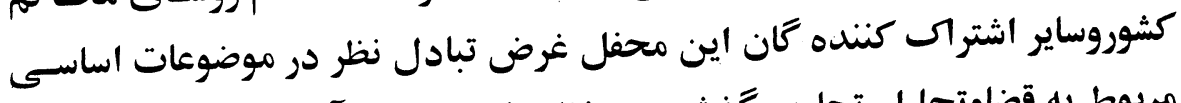

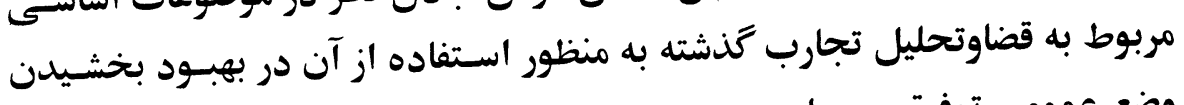

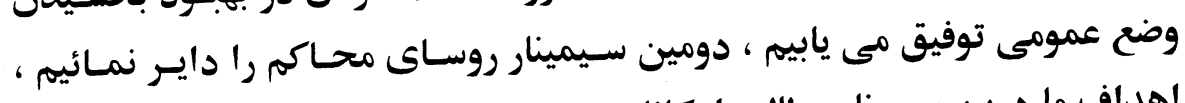

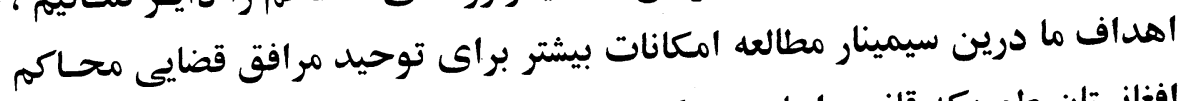

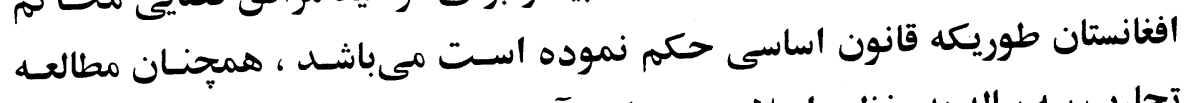

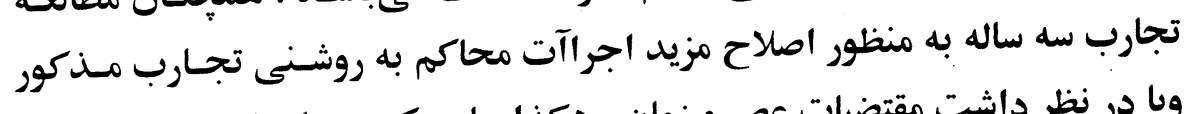

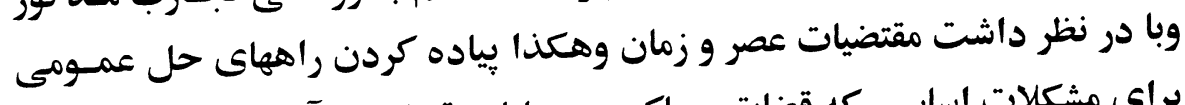

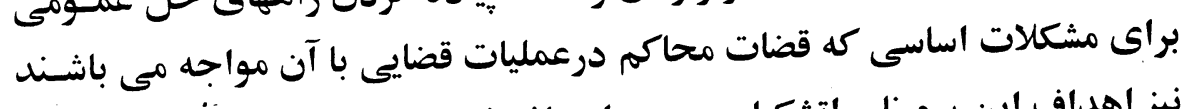

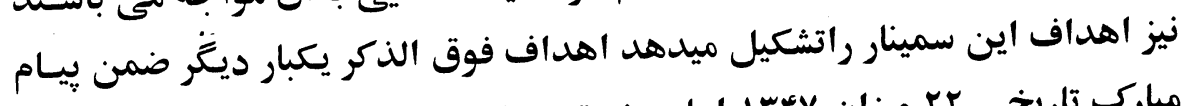

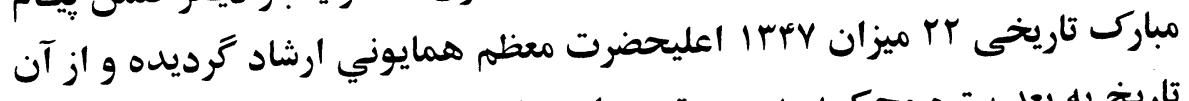

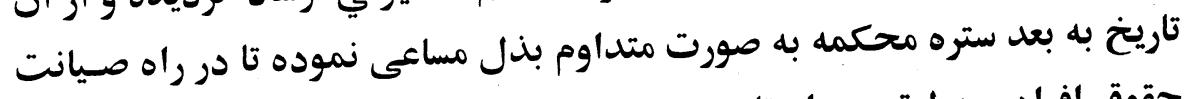

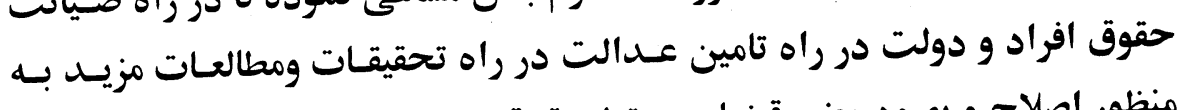

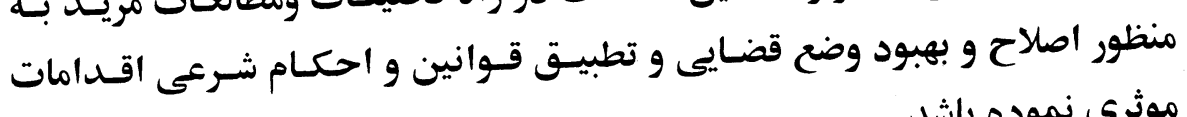
موثرى نموده باشد.

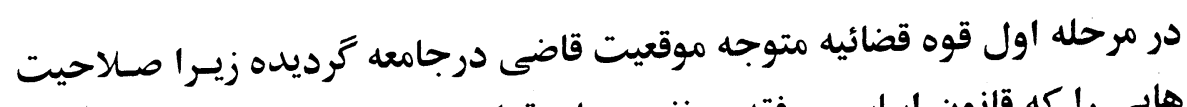

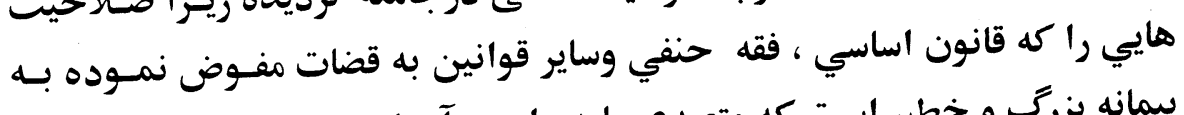

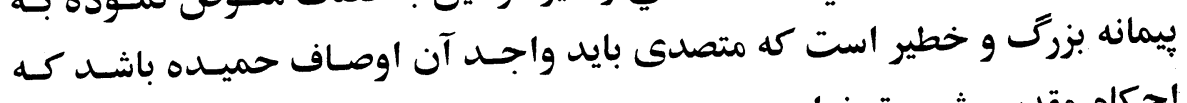

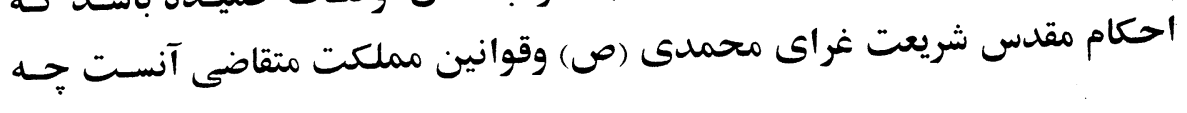


قاضى در حقيقت مسند نشين سيد نا محمد مصطفى (ص) و نايب سلطان در امـور

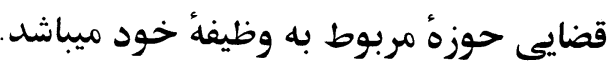
براى اينكه قضات وظيفه مقـدس و خطـير قضـايـى راطوريكـهـ شايسـته ايسن مقـام

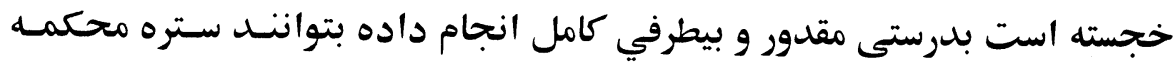

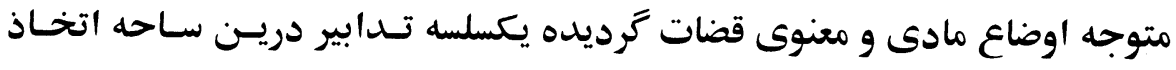

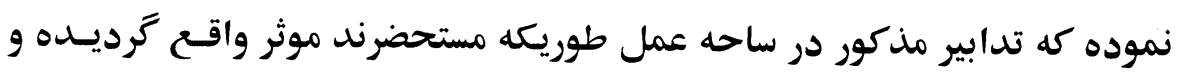
تطبيق تدابير مذكور ادامه خواهد يافت . نمون

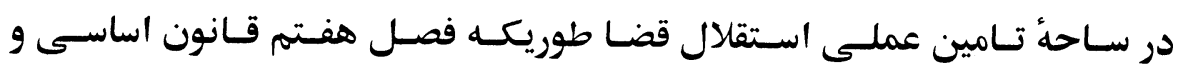

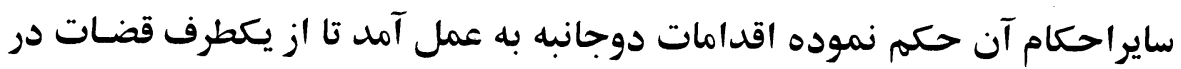

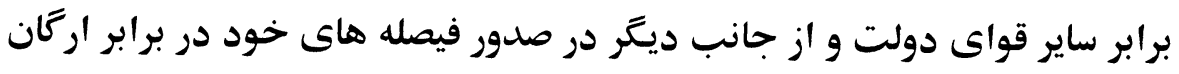

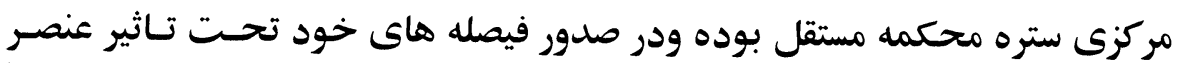
ديَرى به جزاز احكام شرعى و قوانين نيايند .

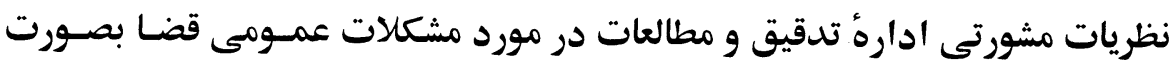

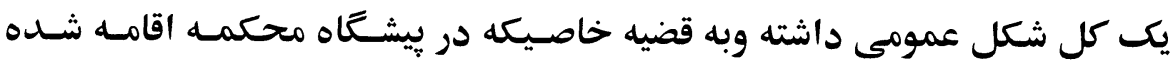

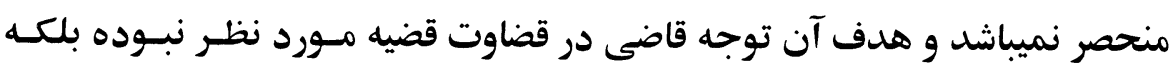

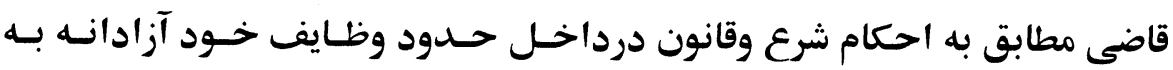
صدور حكم مى يردازند. همجنين احكاميكه توسط عرايض ارجاع ميى تردد صرف توجه قاضى را به تطبيق

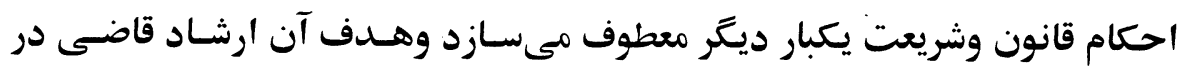

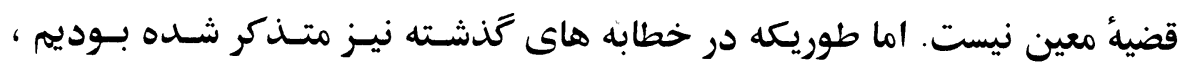

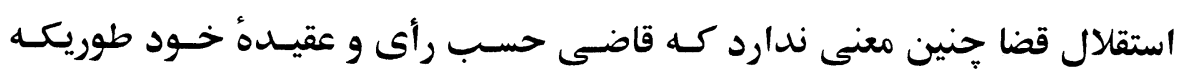

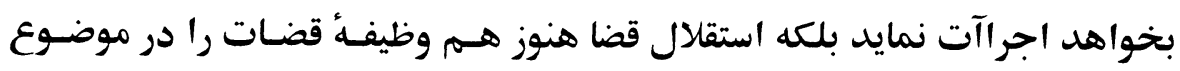

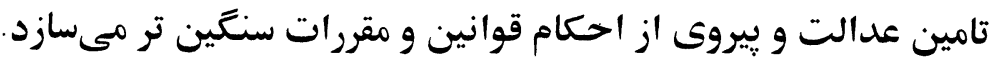


از آنجاست كه مجهز شدن قضات بـه مسـايل علمسى و عملهى قضـايع بـه اسـاس

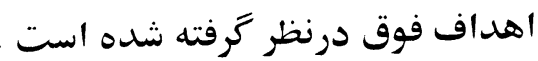

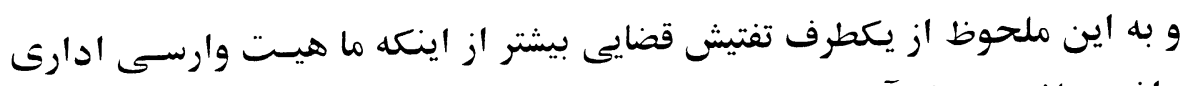

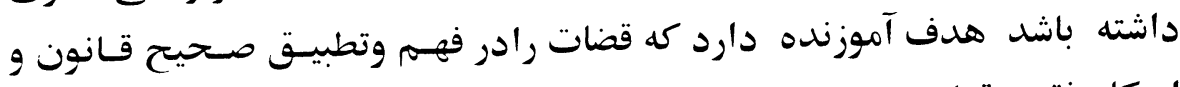

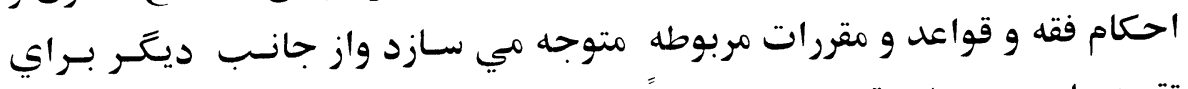

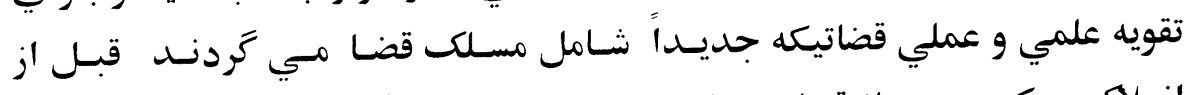
انسلك ، كورس ستاز قضايي براي مدت يكسال داير گرديد كه نتسايج آن روي همرفته مطلوب بنظر ميرسد همجنين در ساحه تنظيم مجدد وظايف تاسيس ديوان هاي رياست هاي محاكم

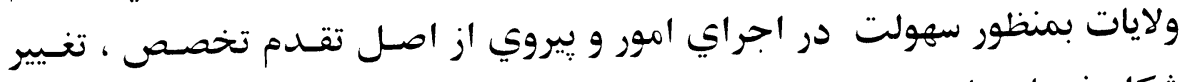

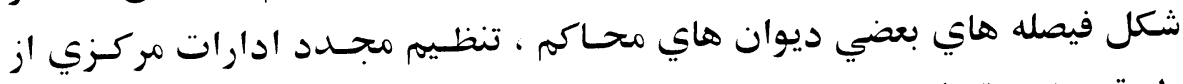

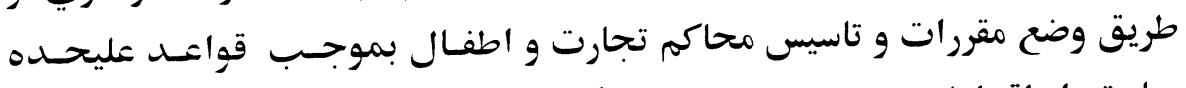

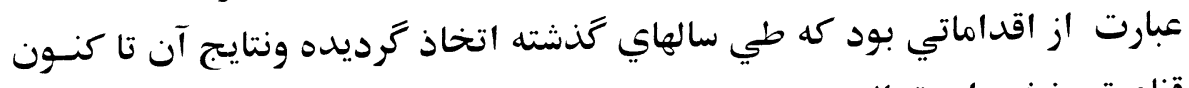

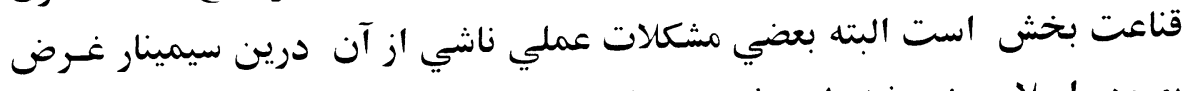
بهبود واصلاح مزيد نيز طرح شده ميتواند

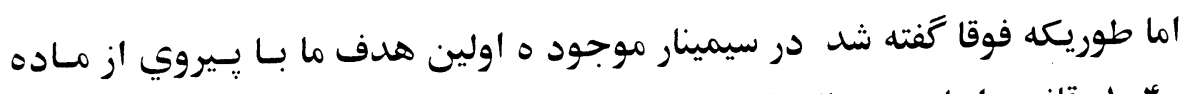

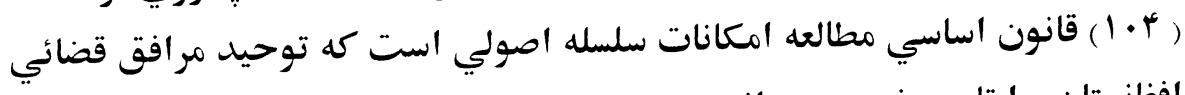

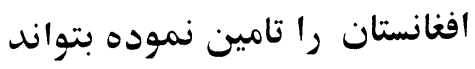
در حال حاضر با اصلاحاتي كه به عمل آمده و يا توحيد فهم در تعبير قـانون كسه

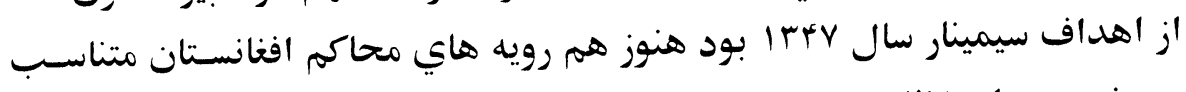

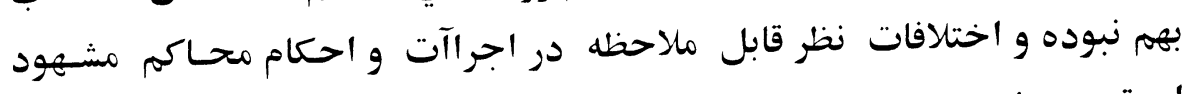

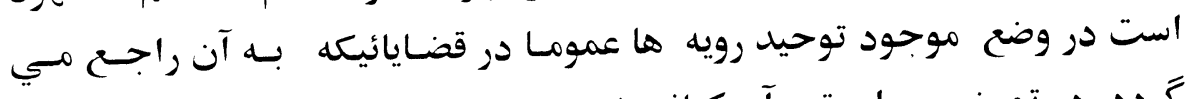

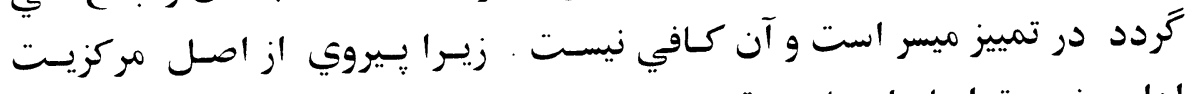

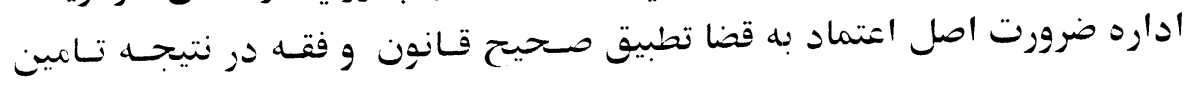


تدالت بوجه احسن مستلزم آنست كه احرآت و فيصله هاي محساكم افنانستان در احو'ل و قضاياي مشابه ماهيت شبيه هم باشد براي نيل به اين منظور ستره محكمه درك نموده كه لزوم وحدت ماحذ ماحذ متتبر ومكمل فقهي وقواعد كلي فقه حنفي به زبان هاي رسمي و استفاده مردم و

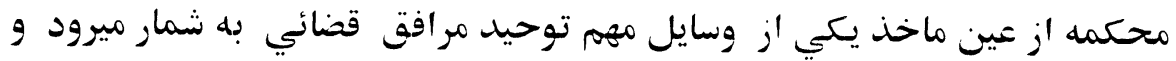

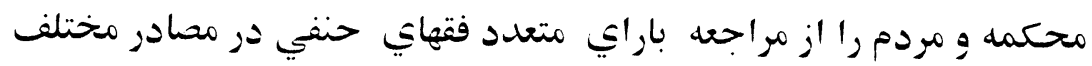

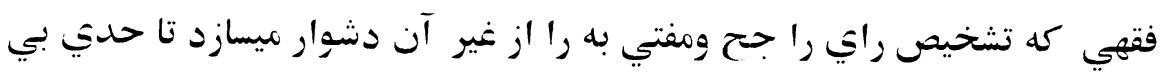

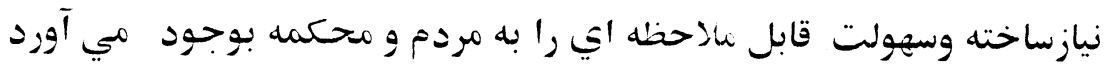

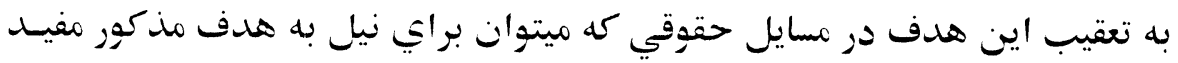

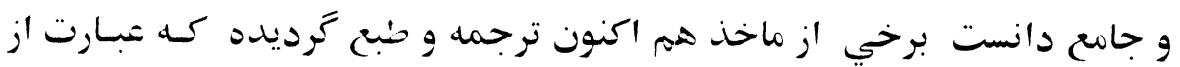

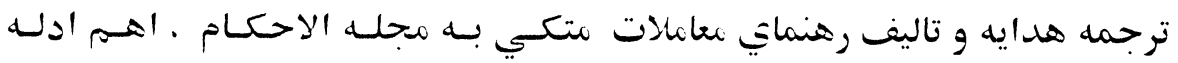

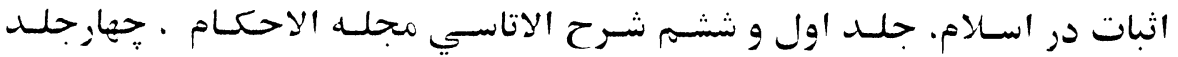

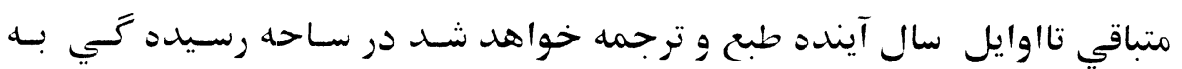

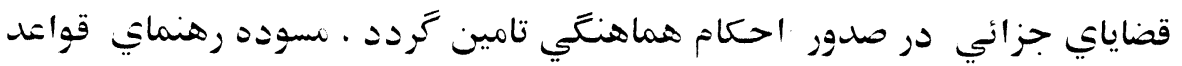

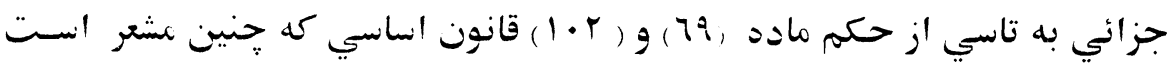

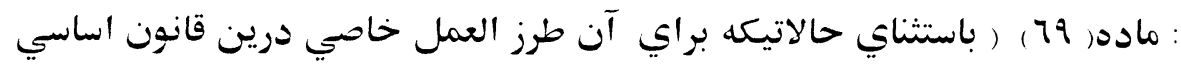
تصريح ترديده قانون عبارت است از احكام فقه حنفي شريعت اسلام )

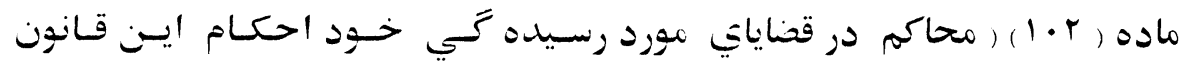

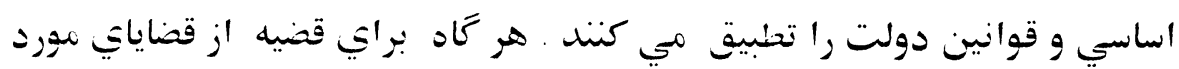

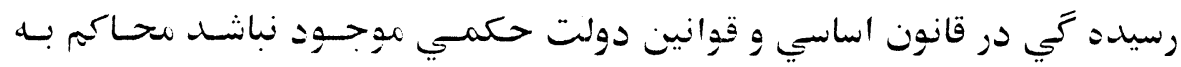
زيروي از اساسات كلي فقه حنفي شريعت اسلام دز داخلى حدوديكه اين قـانون

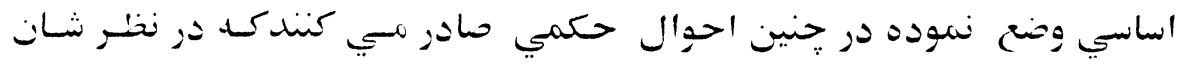

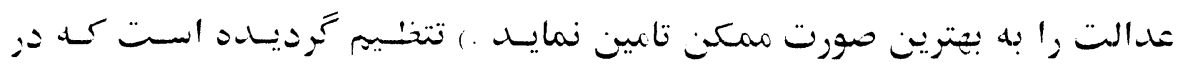

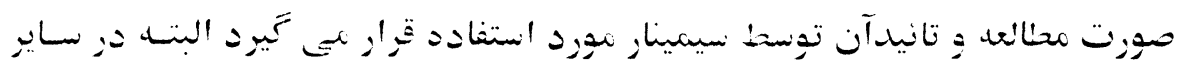




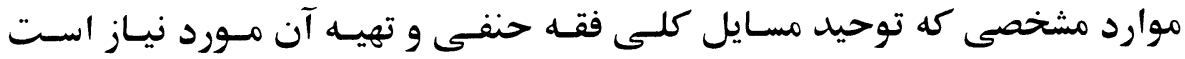

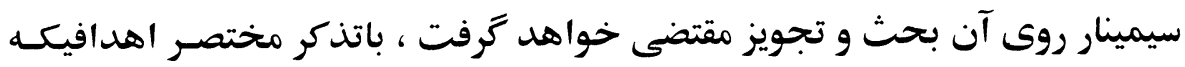

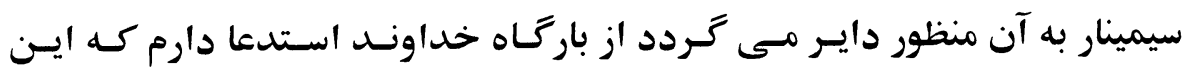

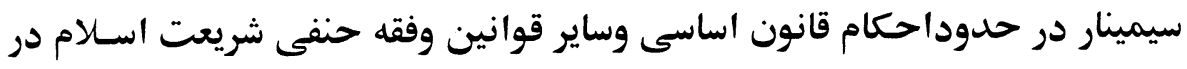

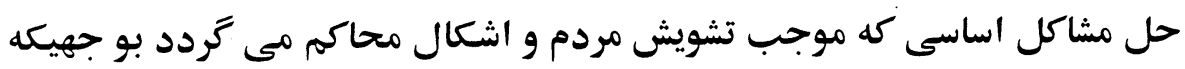

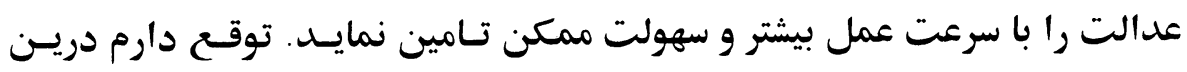

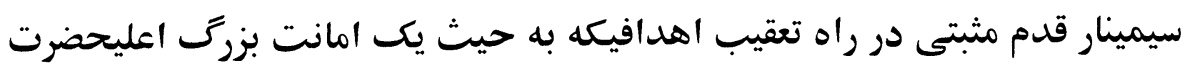

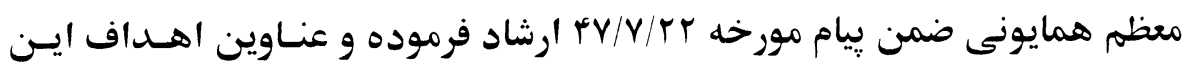

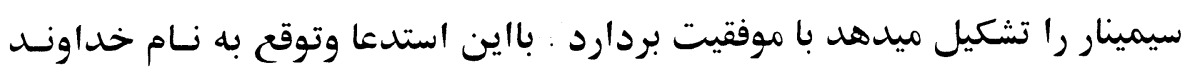

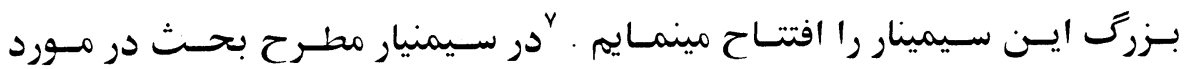

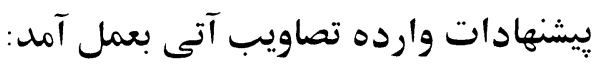

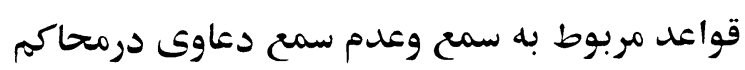

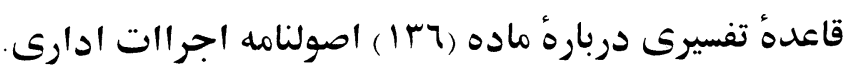

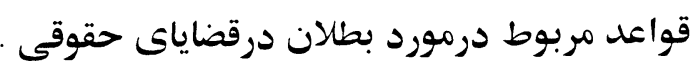

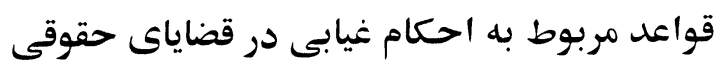

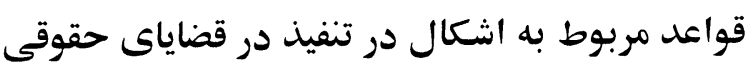

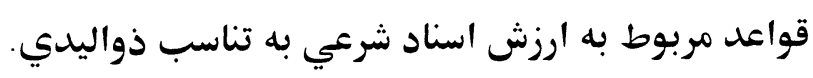

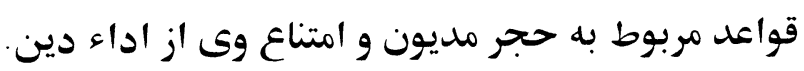

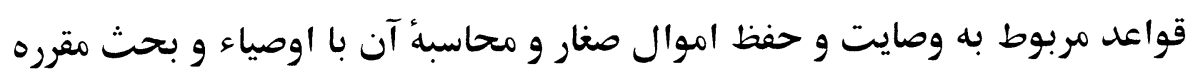
متمم تعليمات نامه وصايت . توايت

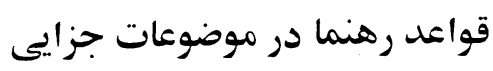
موانع مسوليت جزايى رونما دوضوعات

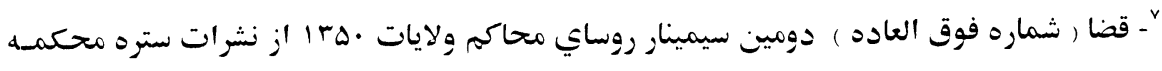

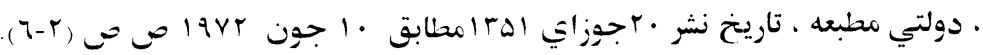




$$
\text { قواعد مربوط به جرم افتراء. }
$$

مقررات مربوط به محصولات در محاكم.

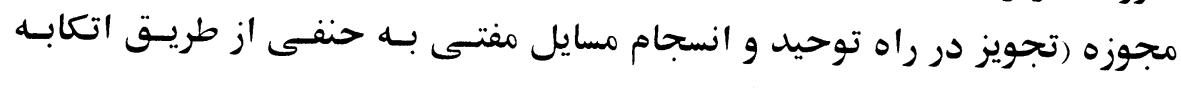

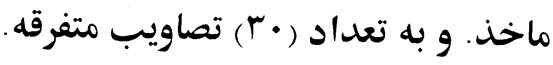

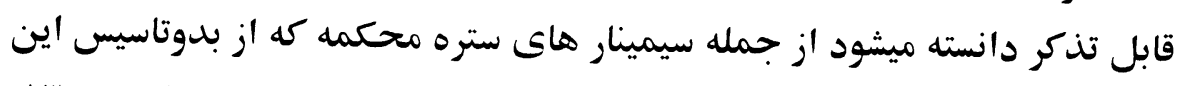

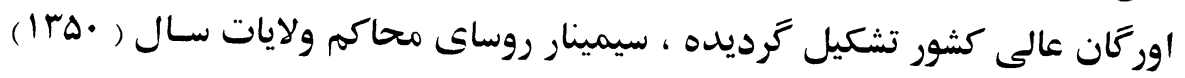

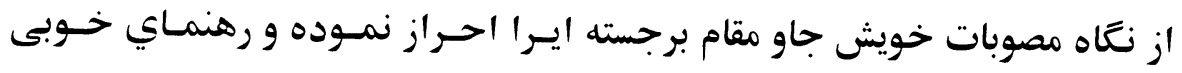

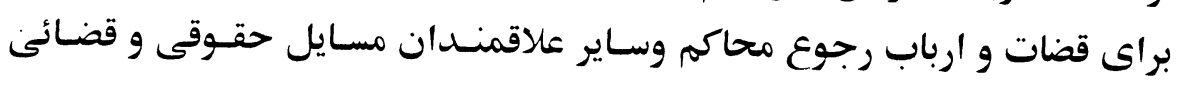

ميباشد .

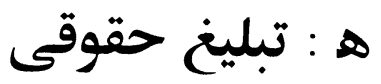

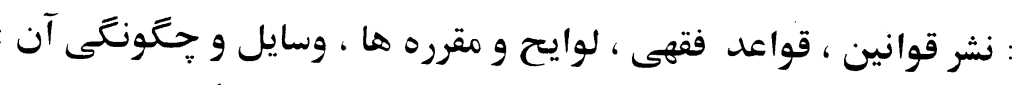

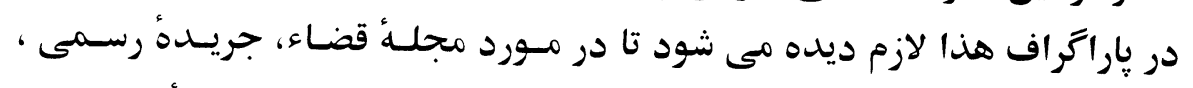

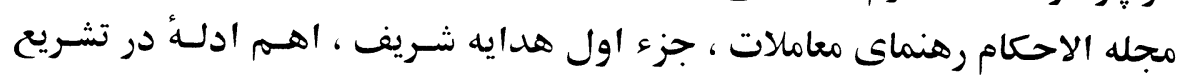

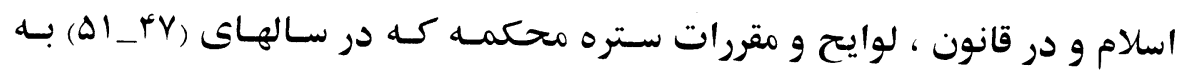

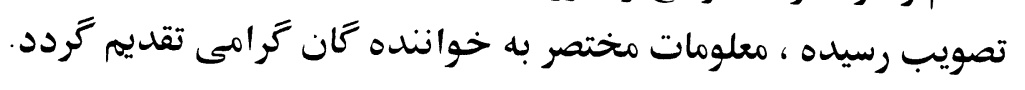
1 _ مجلة قضا:

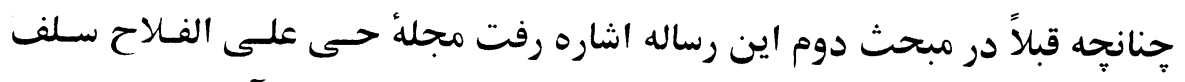

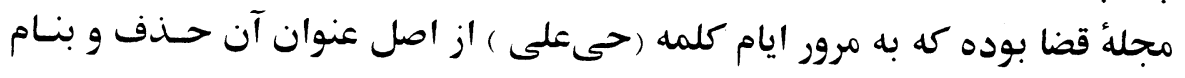

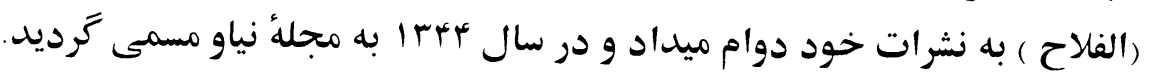

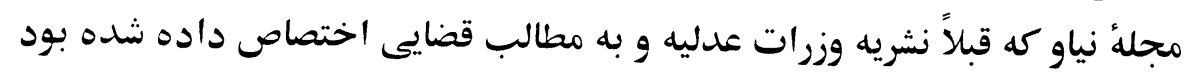

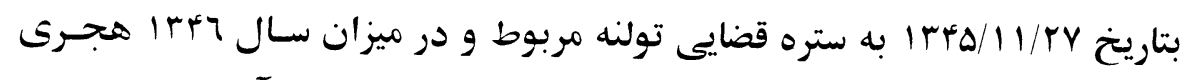

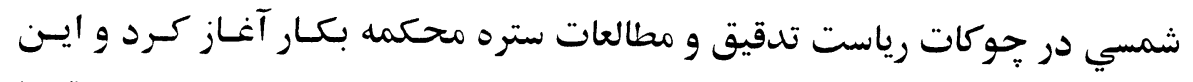

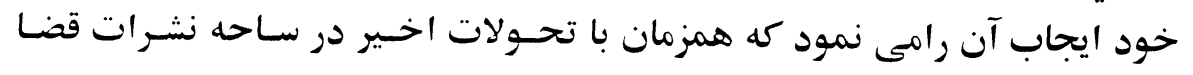

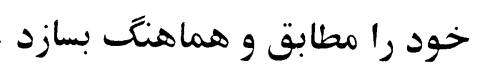


روى همين منظور فوق بود كه در حشوه يككى از ريشـنهاد هـاى مـديريت مجلسه.

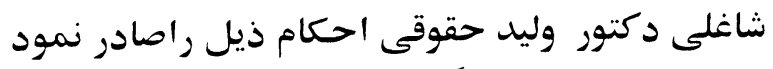

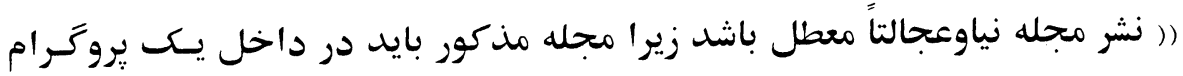

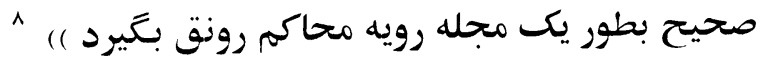

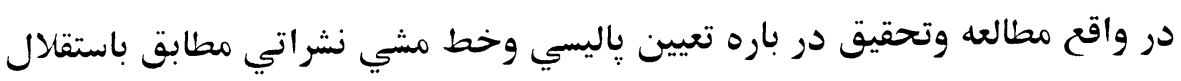

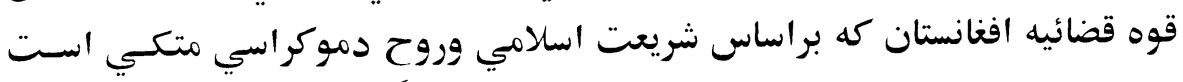

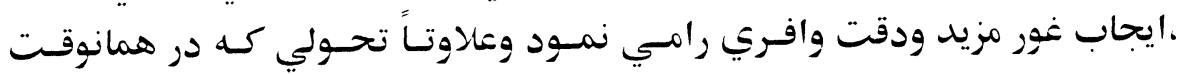

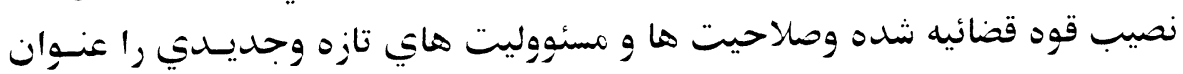

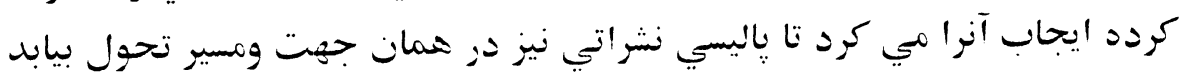
• روتي اين طرز تلقي وبراساس هميـ واقع بيني دقيق بود كسه يسك هيسات بـراي

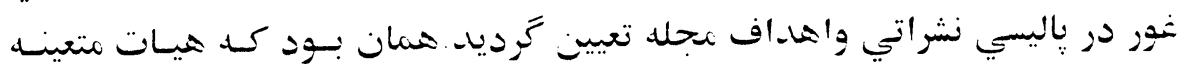

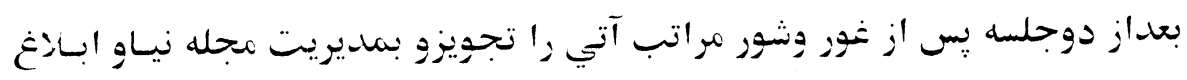
نمودند نام : قضأ:

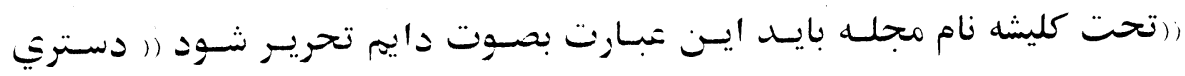

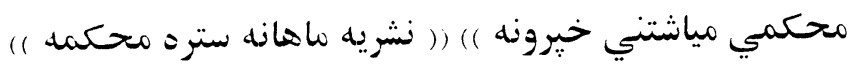

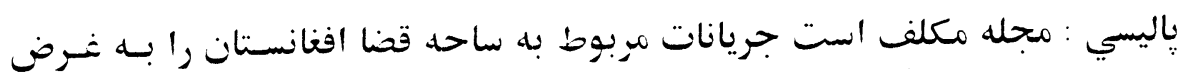

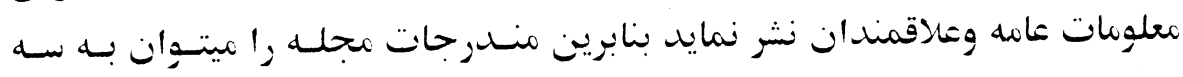
كتيتغوري ذيل تقسيم كرد الف : خبرهاي ستره محكمله : اين قسمت بايد محتوثي باشهد

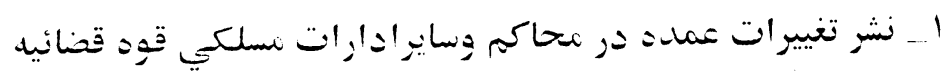

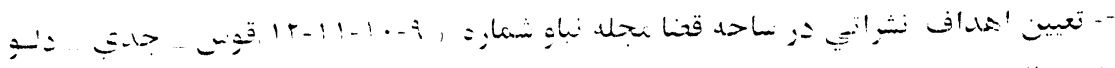

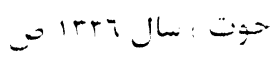
(5) 
r._. معرفي اشخاصيكه جديداً به ساحه قضا واردميشوند

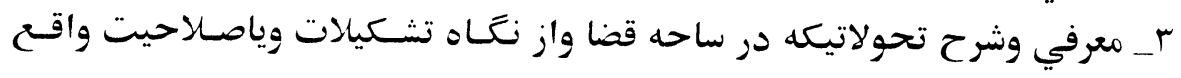
ميكردد

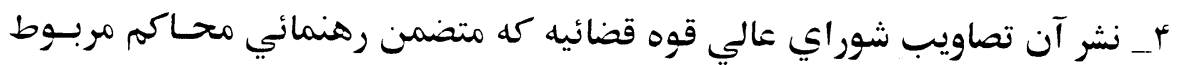

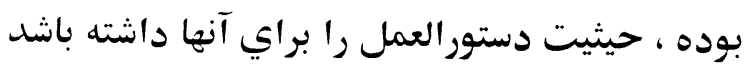

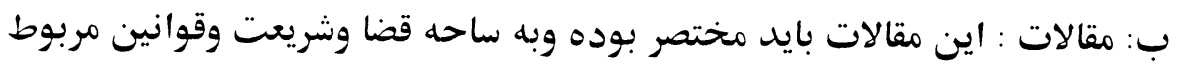

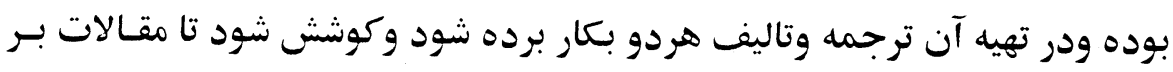

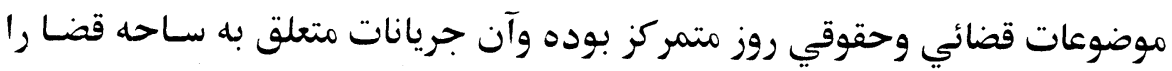

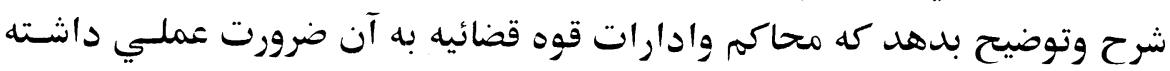

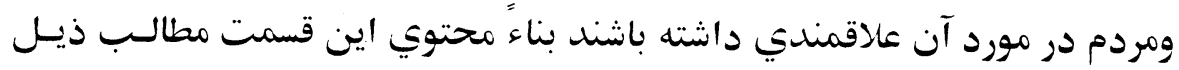
را تشكيل ميدهد

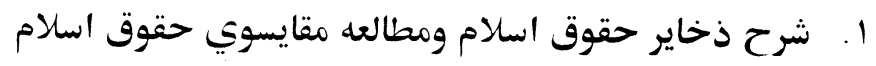

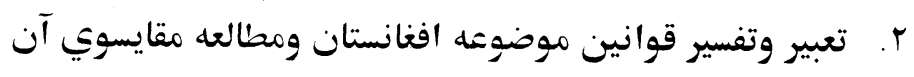

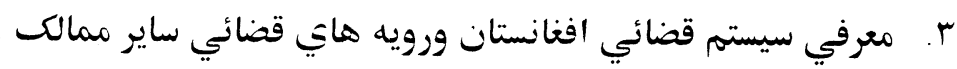

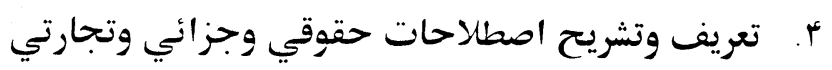

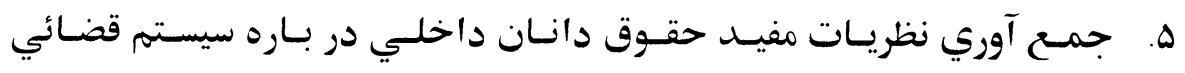
افغانستان

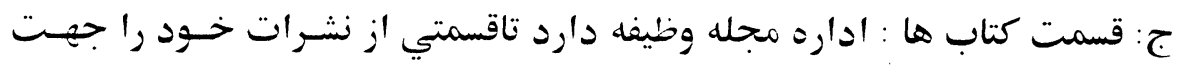

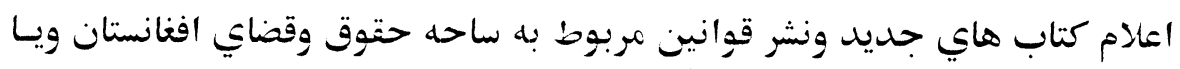

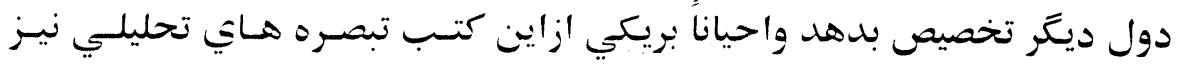
بنويسد.

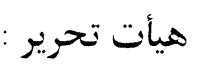

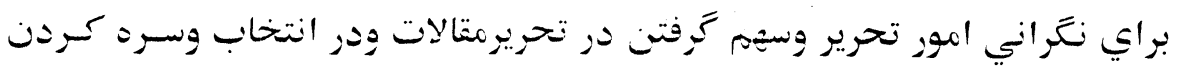

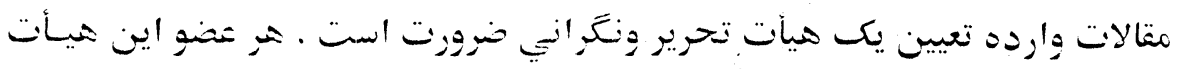

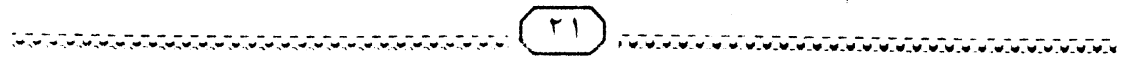


موظف است هر دو ماه يكمقاله براي مجله بنويسد ومقاله وارده راتدقيق نمايسـ

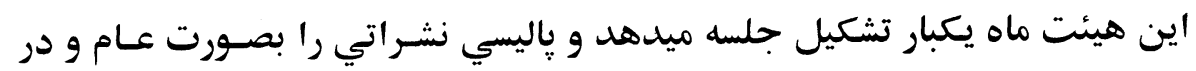

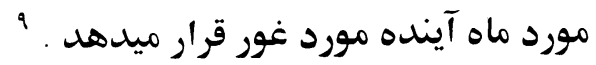

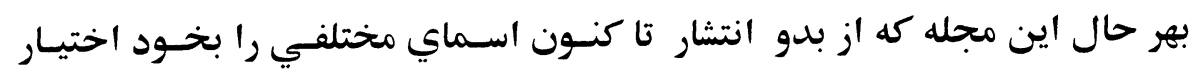

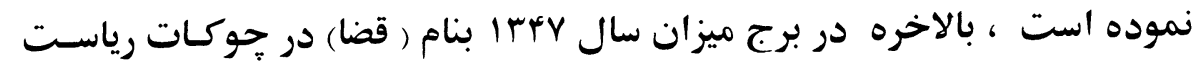

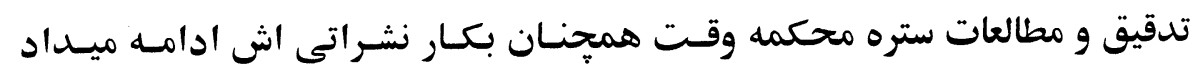

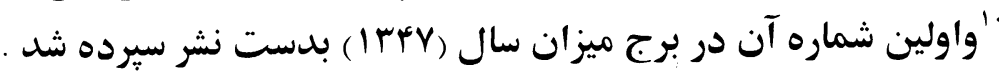

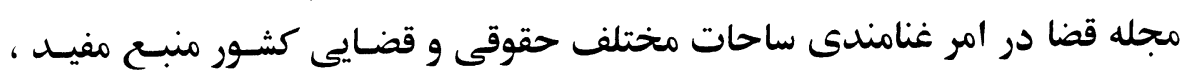

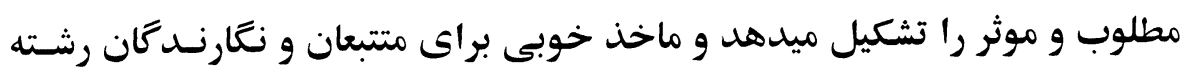

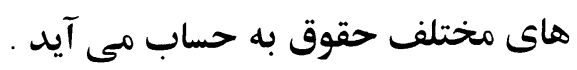

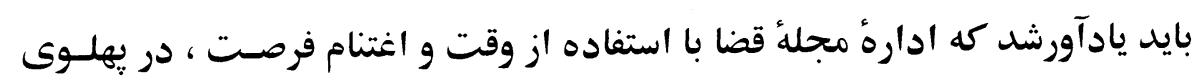

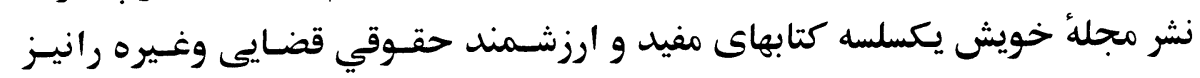

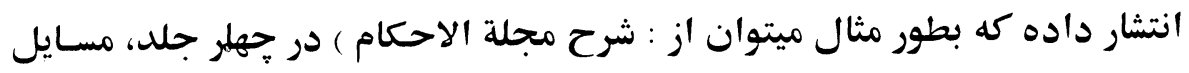

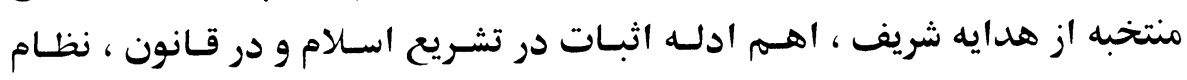

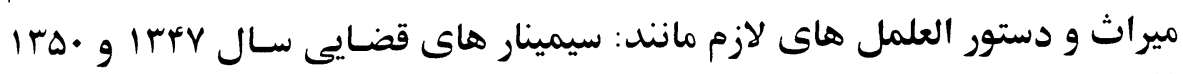

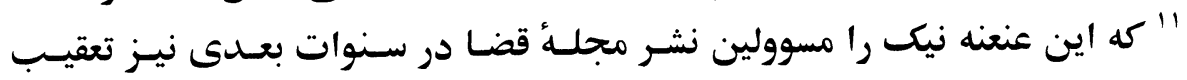

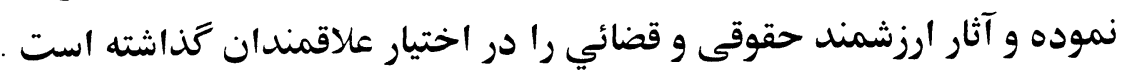

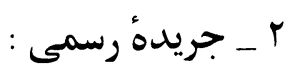
نشر اسناد تقنينى درحيات سياسى ، اجتماعى ، إسى ، اقتصادى ، فرهنتى و سـاير سـتون

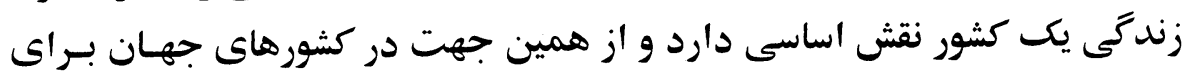

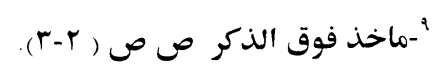

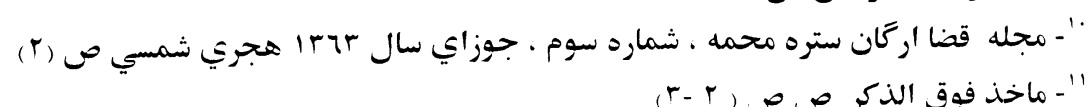

(T) 
نشر قوانين وساير اسناد تقنينى واسناد با ارزش جريده يـا روزنامـهُ رسـمى وجــود دارد در كشور عزيز ما افغانستان ايجاد جريده رسمى در سال ب ب آ بوجود آمد وقانون

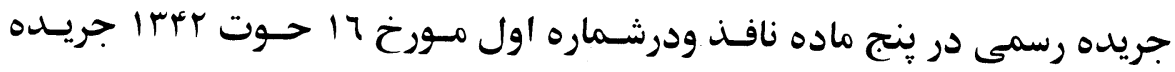

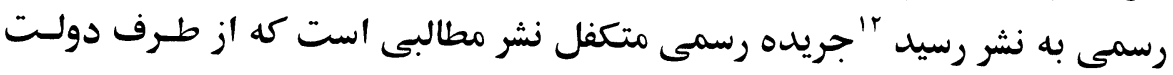

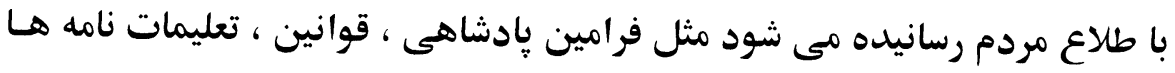

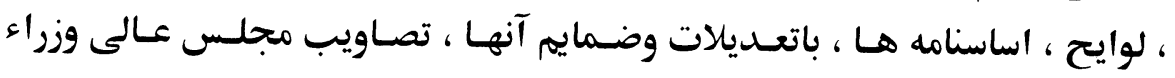

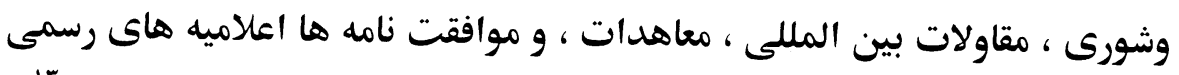

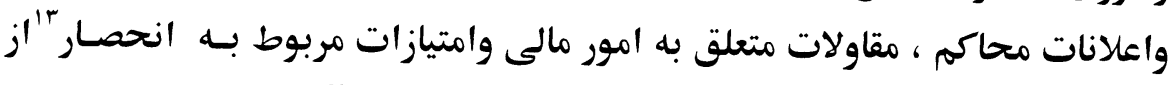

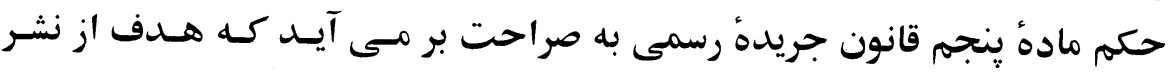
قوانين و اسناد تقنينى و موضوعات قابل نشر در جريده رسمى رئ آتاه ساختن مـردم از متون آنست

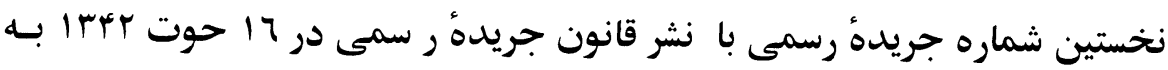

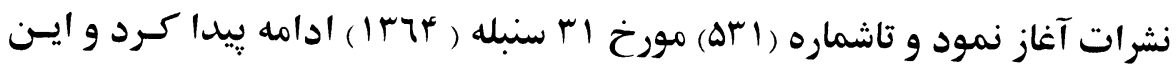

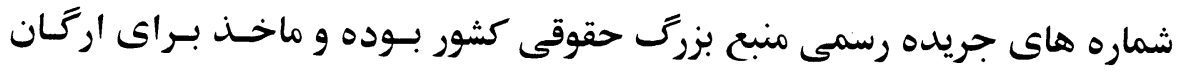
هاى دولت به خصوص ارگًان هاى حفظ و حراست حقوق وقـانون وسـاير اتبـاع كشور به حساب مى آيد . با نشر قانون جديد جريده رسمى در شماره

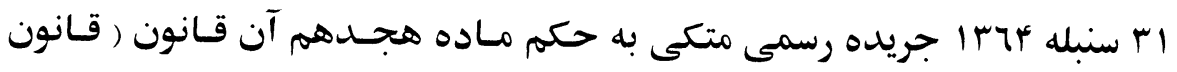

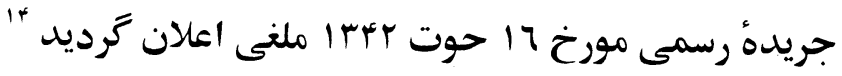

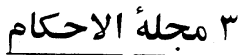

"' هدف از نشر جريده رسمي دولت جيست ؟ مجله حقوق و زنده تي ، شـماره سـوم ، قـوس

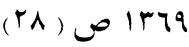

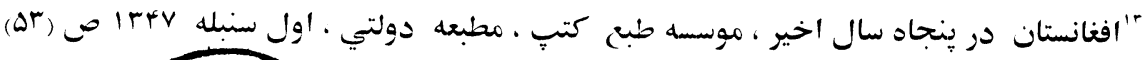

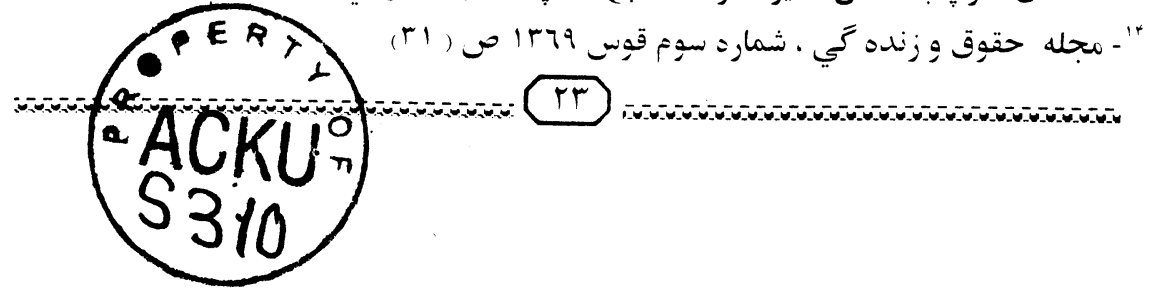


قبل از آنكه در مورد ترجمه و نشر مجلة الاحكام از طرف ستره محكمه افغانسـتان

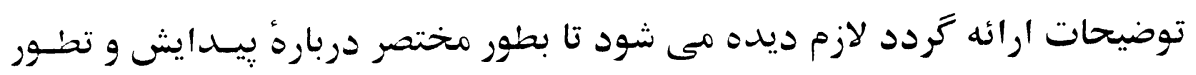

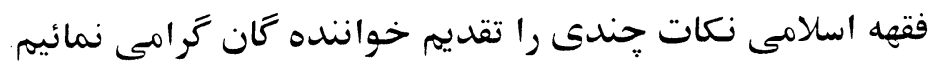

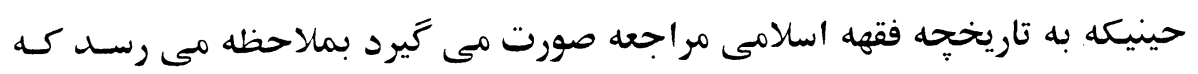

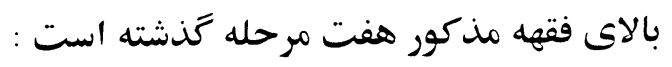
ا مرحلة اول : مرحلة حيات رسول الهه صلى الشه عليه وسلم

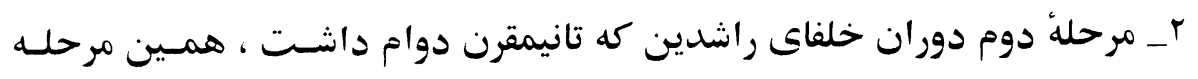

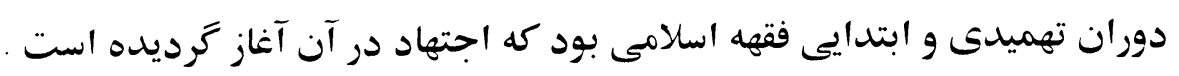

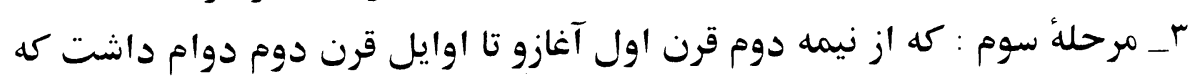

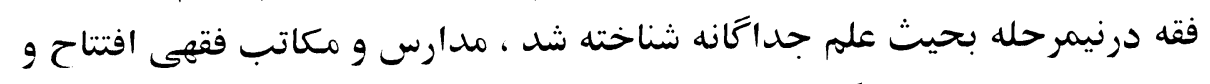

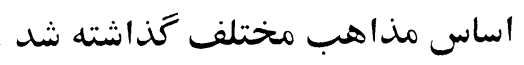

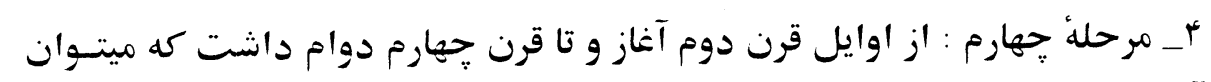

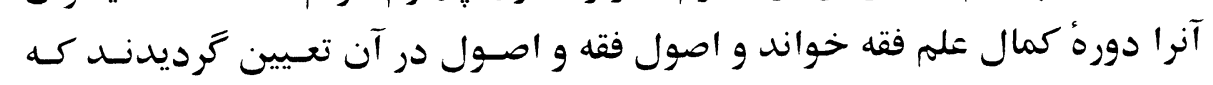

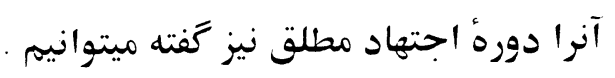

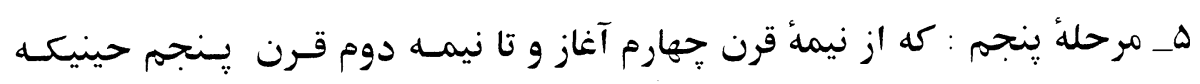

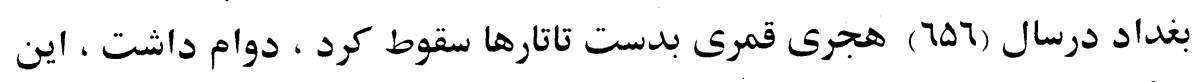

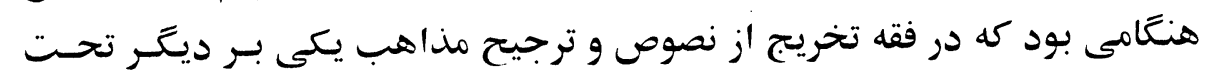
بحث و مداقه قرار ترفت

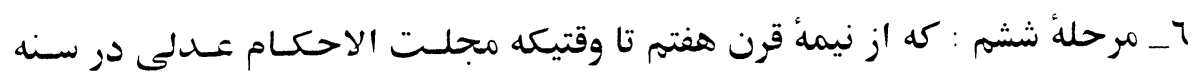

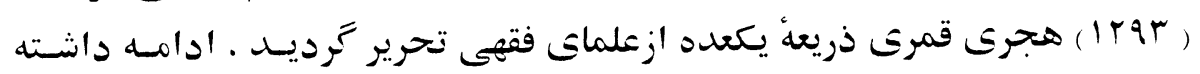

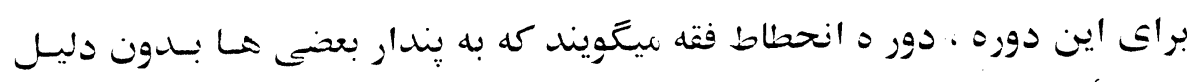

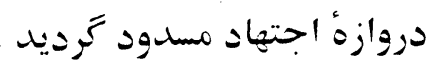

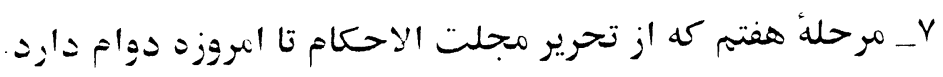


در اواخر قرن سيزدهم هجرى قمرى دولت شثمانى ملتفت ترديد كمه براى تقنين

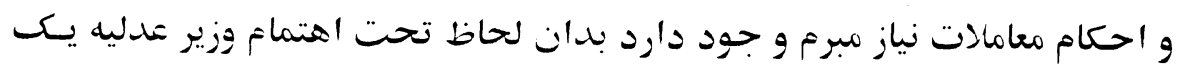

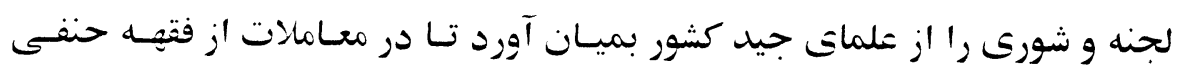

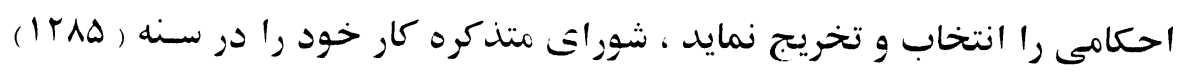

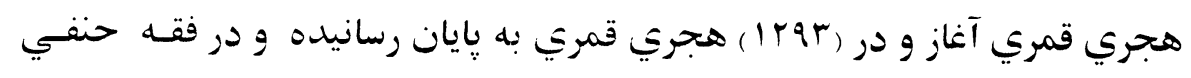

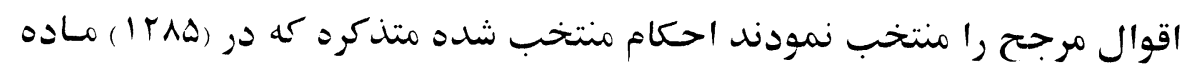

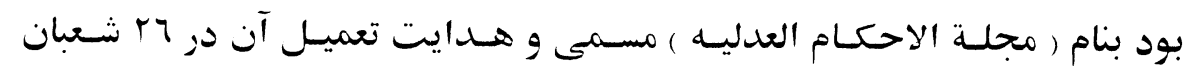

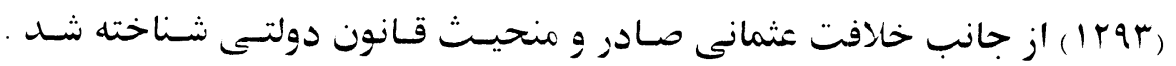

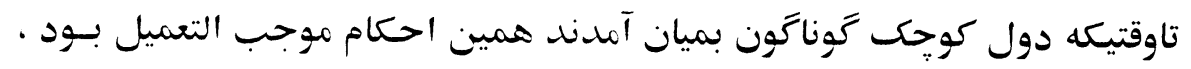

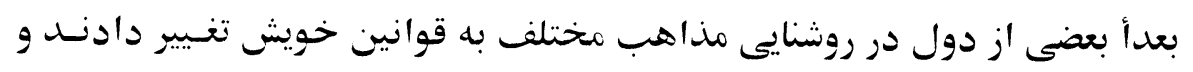

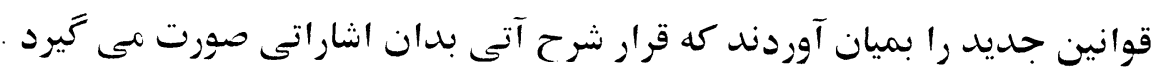

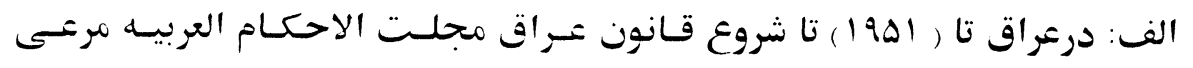

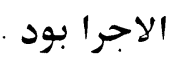

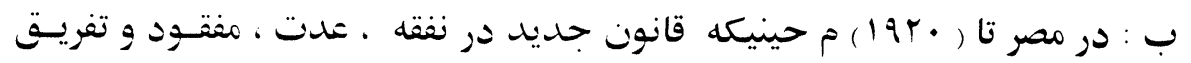

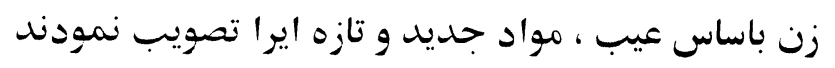

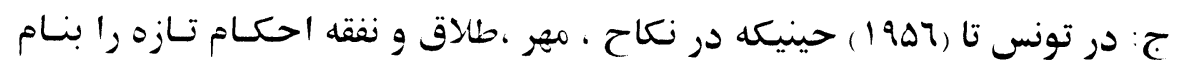

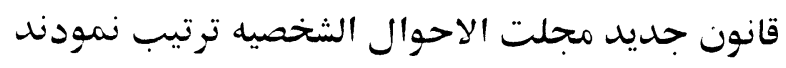

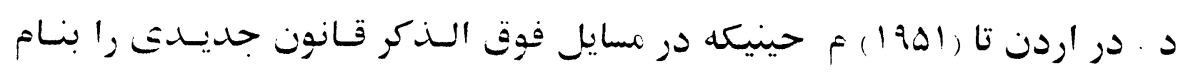
حقوق العايله تصريب نمودند الردون

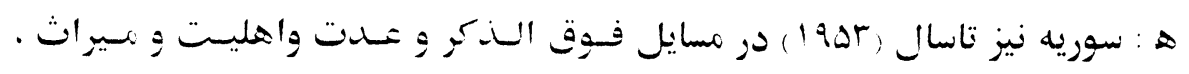

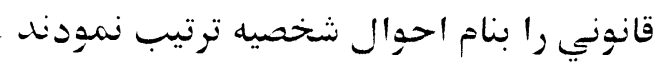

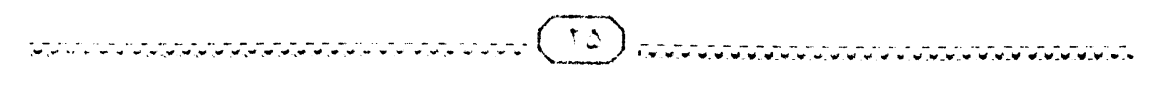


ناتَفته نبايد تذاشت كه هملُ قوانين جديد ، مذهب خاصى را در نظر نتَرفته بود

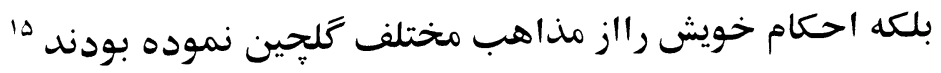

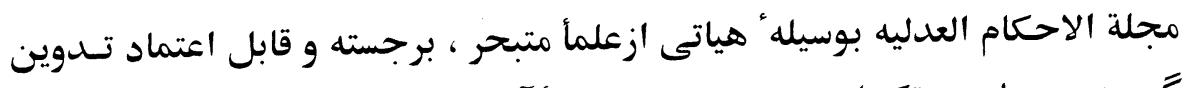

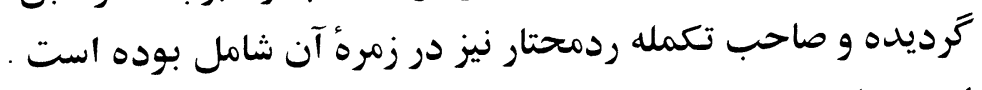

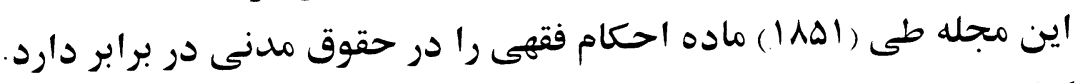

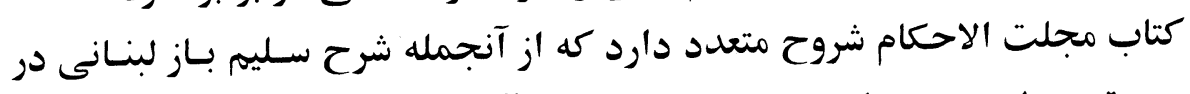

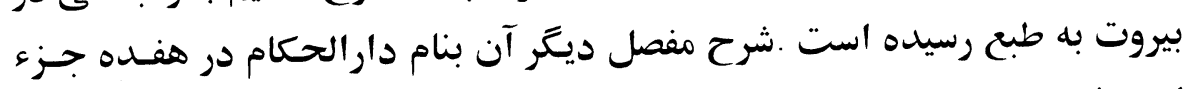

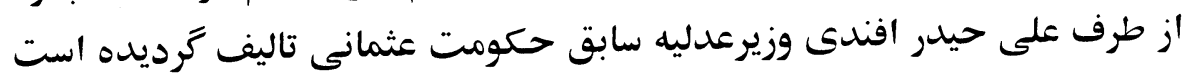

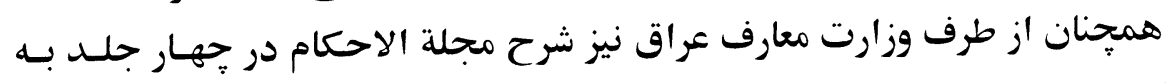

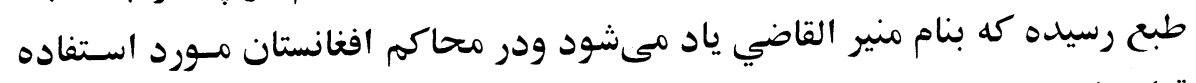

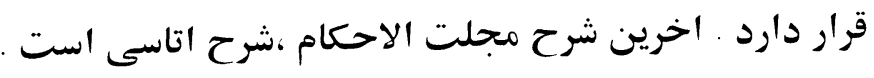

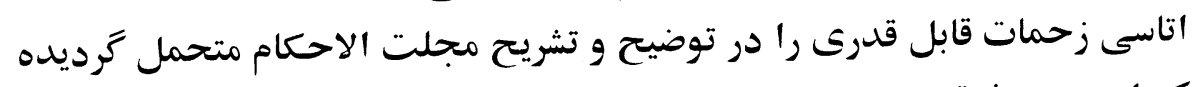
كه از هر حيث قابل تمجيد ودر خورستايث ميباشد .

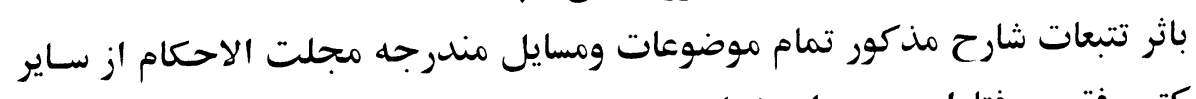

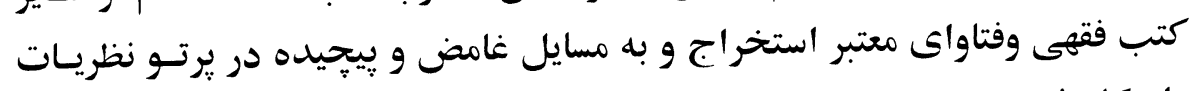

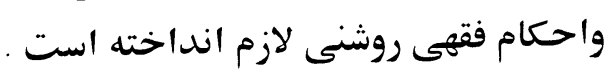

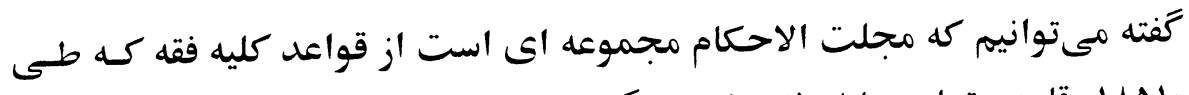

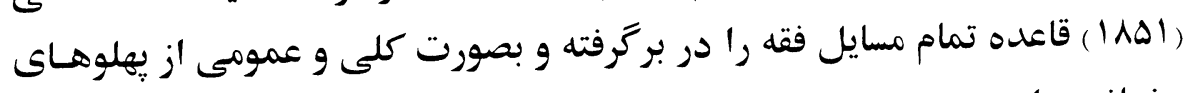
مختلف برامور تعبى و معاملات روشنى انداخته است

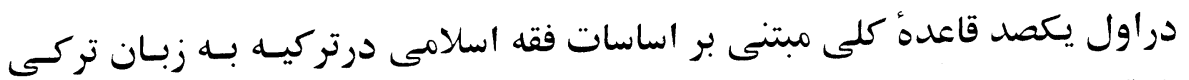

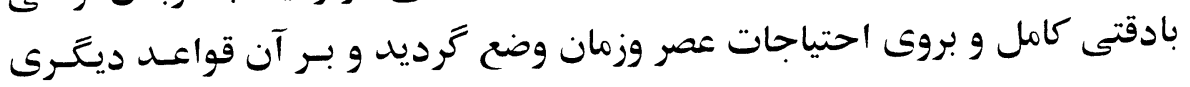

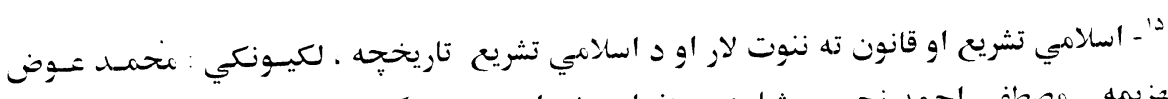

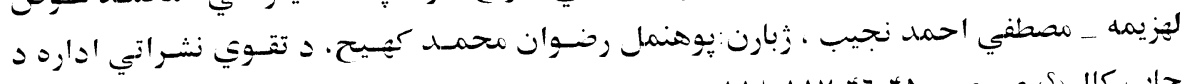

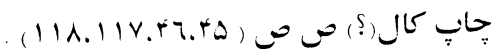


تزئيد شد وجون اين قواعد كـاملاً براساسـات فقـه و بـر تخـريج و اسـتنباط امـام

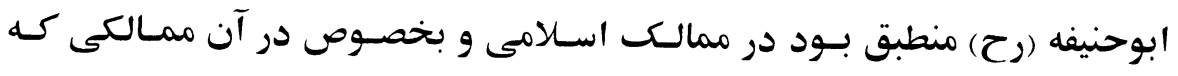

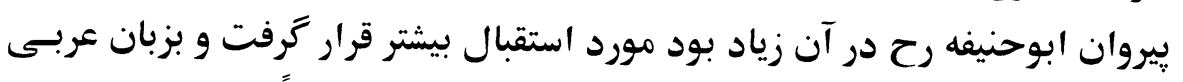

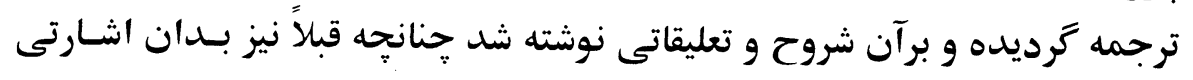

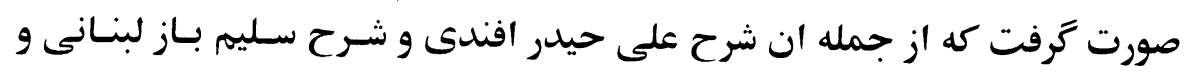

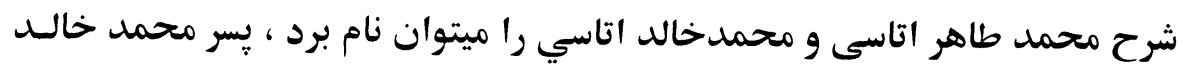

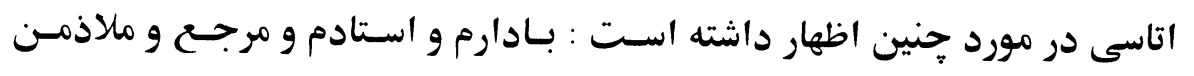

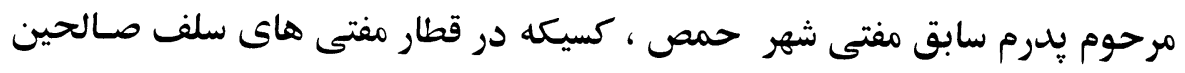

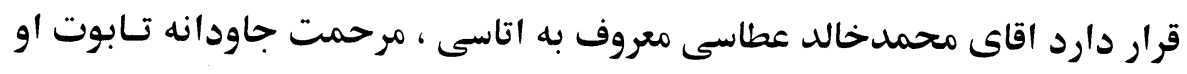

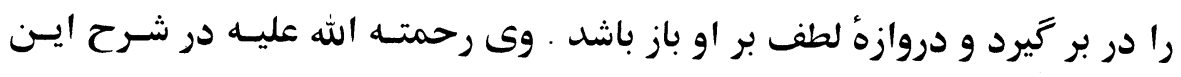

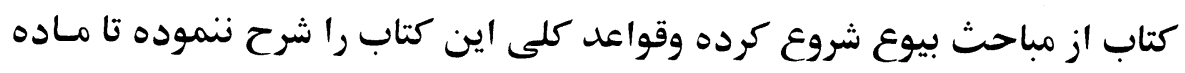

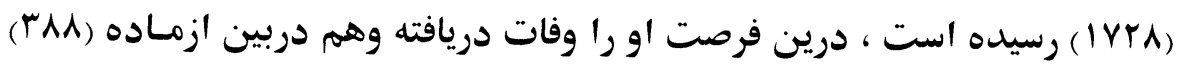

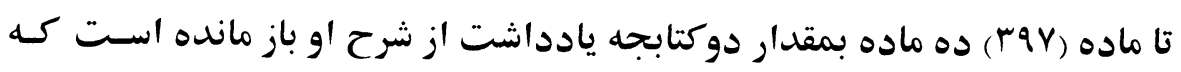

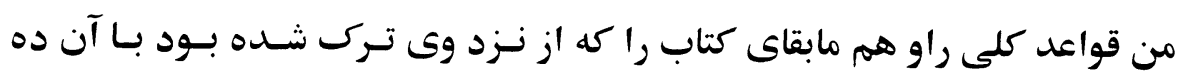

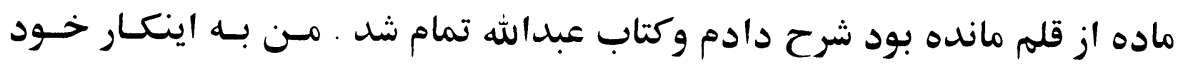

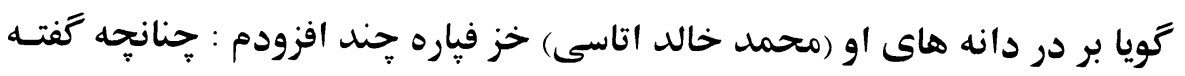

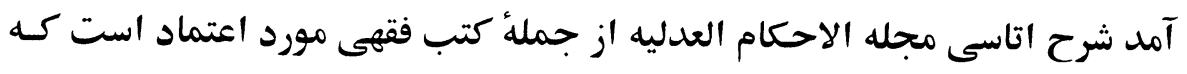

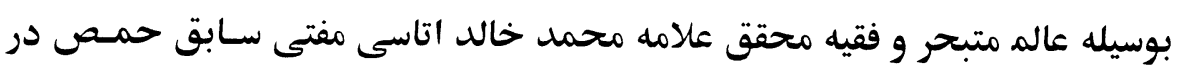

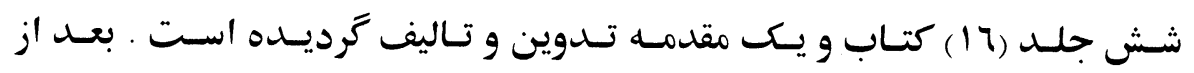

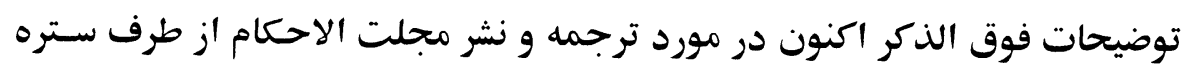

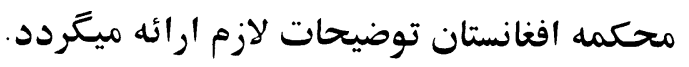

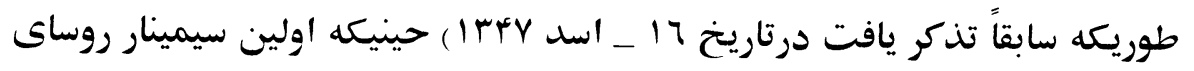

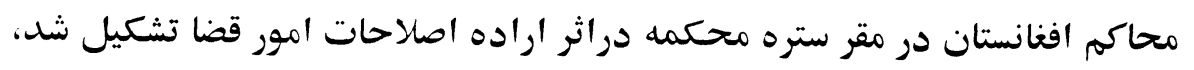

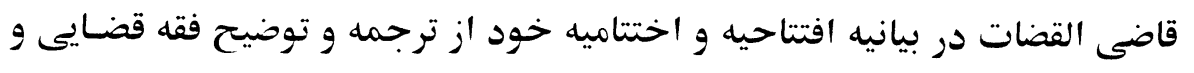


وسعت آن بزبان هاى درى و يشتو كه همه طبقات مردم و منسوبين قضا اسستفاده

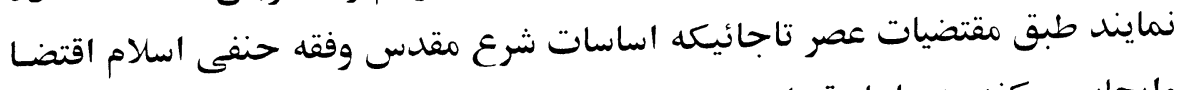

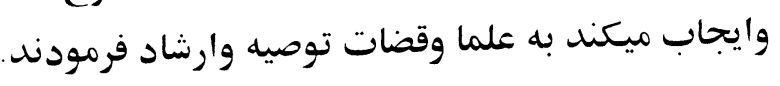

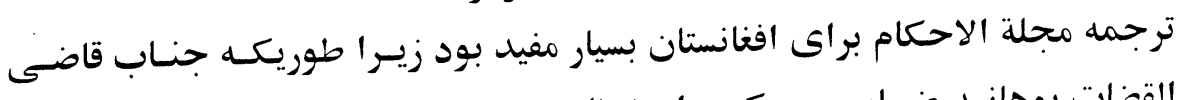

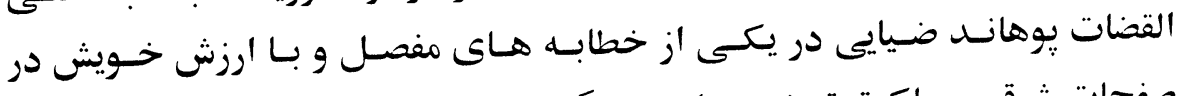

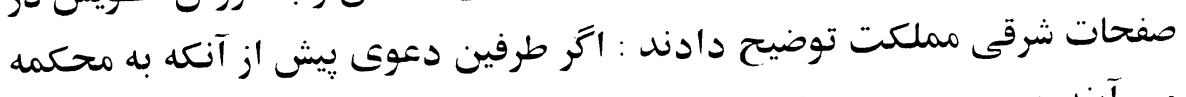

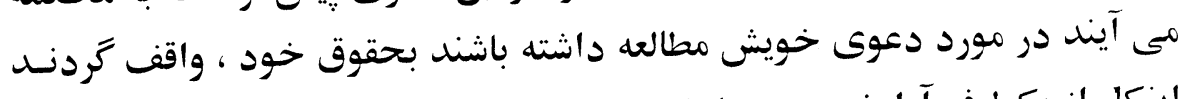

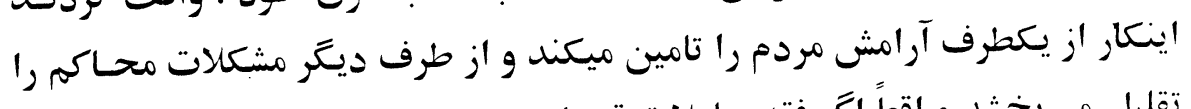

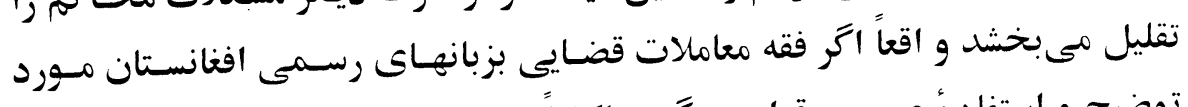

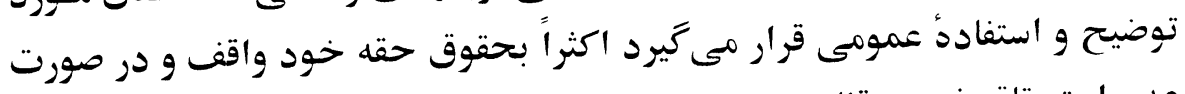

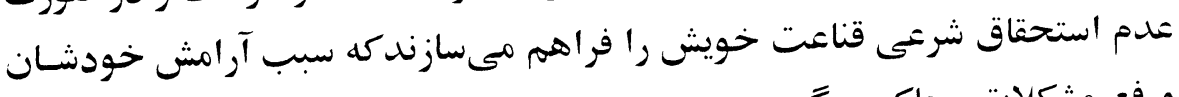
ورفع مشكلات محاكم ميكردد. از همين جابود كه ستره محكمه تجويز كردتا كتاب شرح اتاسى مجلست الاحكــام

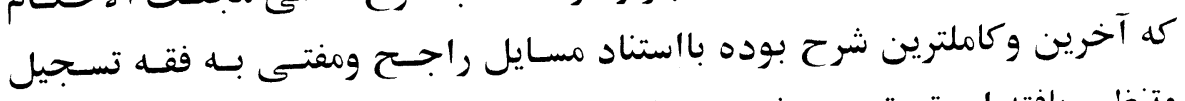

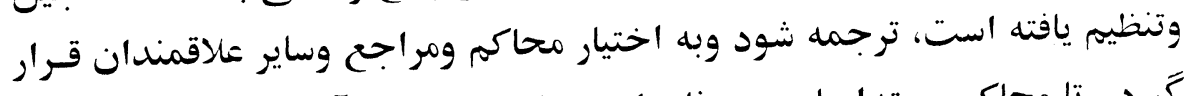

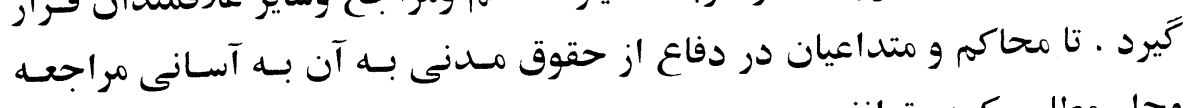
وحل مطلب كرده توانند. ذينا بطور اختصار در مورد قسمت هـاي ترجمسه شـده مجلــة الاحكسام اشـاراتي

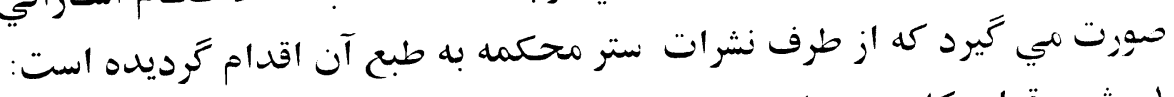
ا ــ شرح قواعدكليه و ضوابط عموميه مجلة الاحكام العدليه.

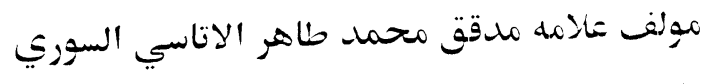

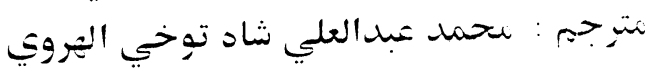

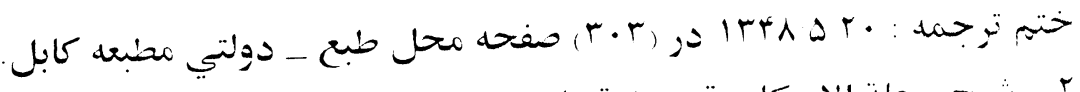

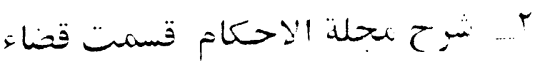


مولف محمد طاهر اتاسي

مترجم : محمدصديق راشد سلجوقي

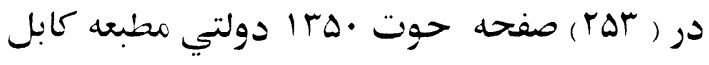

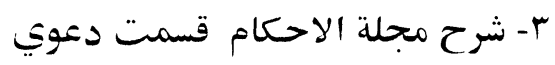
مولف محمد خالد اتاسي مترجم : محمد صديق راشد سلجوقي مبري

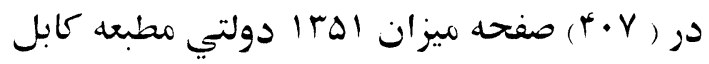

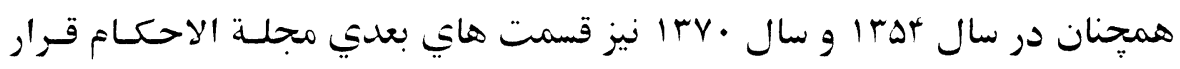

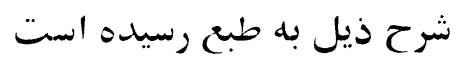

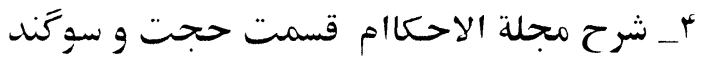
مولف : محمد خالد اتاسي مترجم : محمد صديق راشد سلحوقي : متحمب

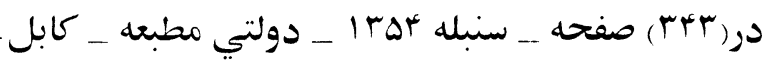
شرح مجلة الاحكام قمست اول شر كتها مولف محمد خالد اتاسي

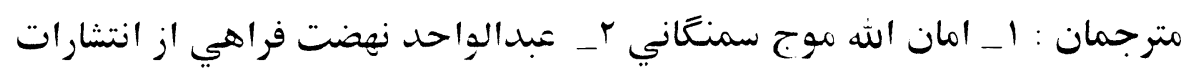

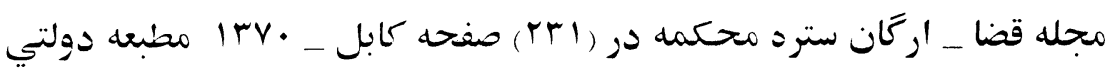

$$
\text { شرح مجلة الاحكام دوم : شركت هات }
$$

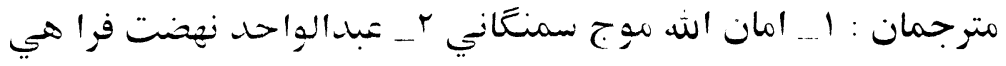

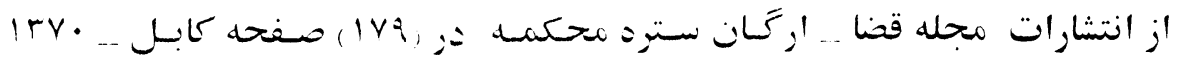
مطنبعه دولتي أسلي 


$$
\text { شرح مجلة الاحكام }
$$

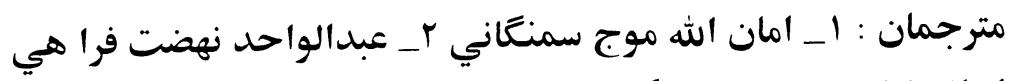

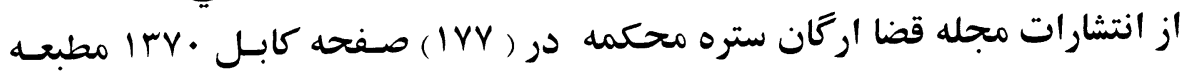
دولتي همحنان ترجمه قسمت حهارم شرح متذكره به همين ترتيب در همان سال طبع و انتشار يافته است ادامه دارد 
مترجم : الحاج محمد عمر فاروق ترجمه ازكتاب سراجي با استفاده از شريفيه بيوست به تخدته

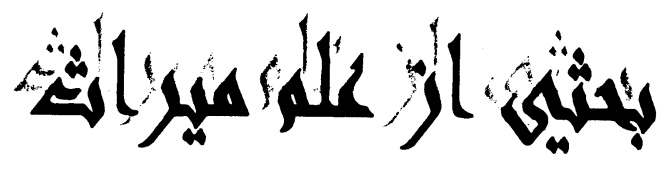

\section{فصل صنف دوم}

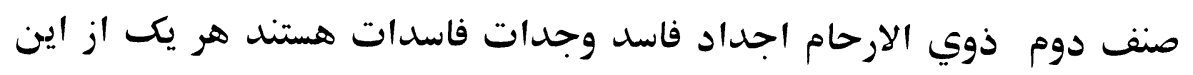

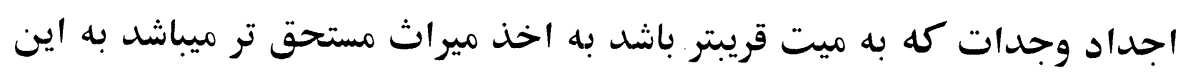

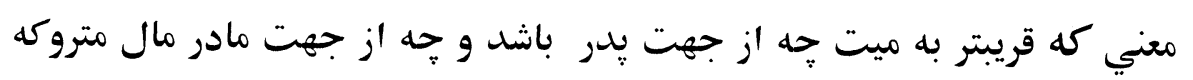

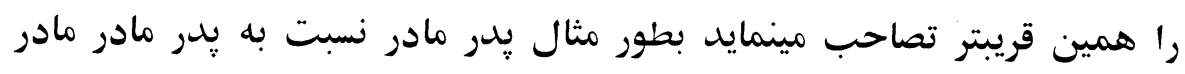

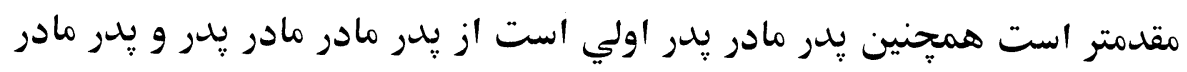

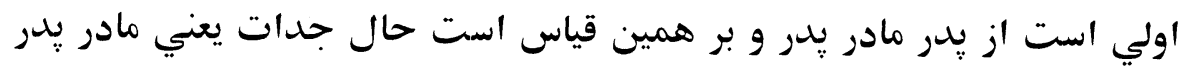

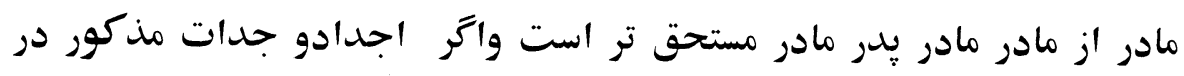

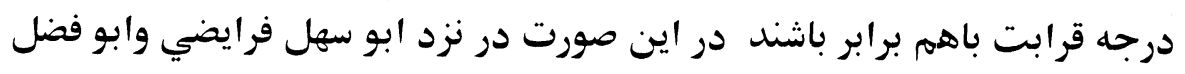

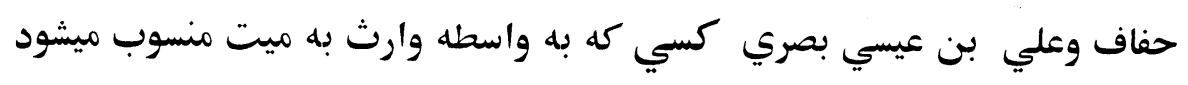

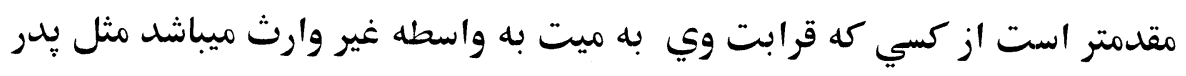

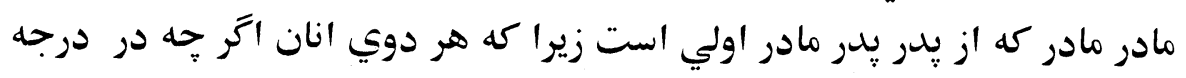

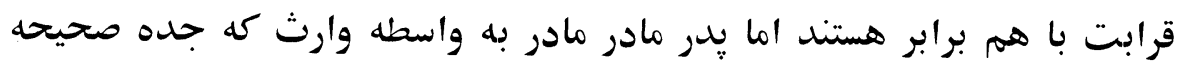

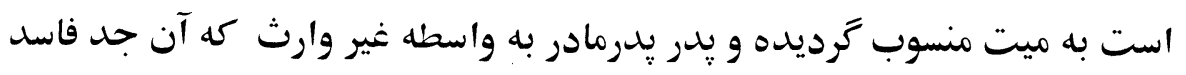

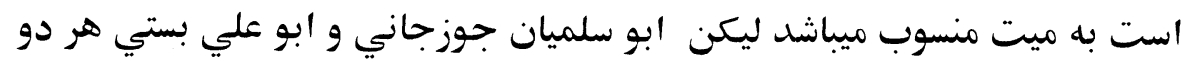

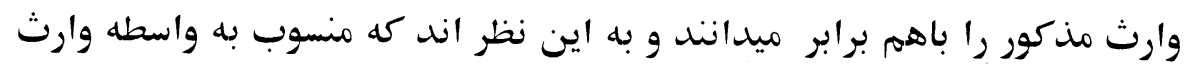

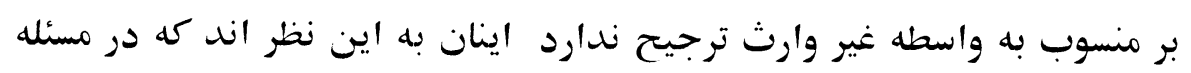

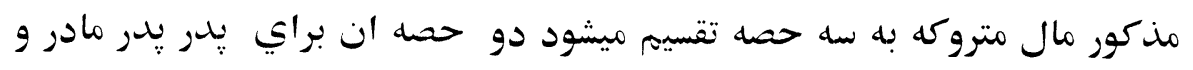




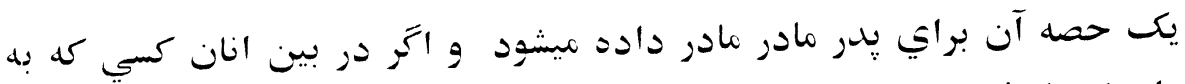

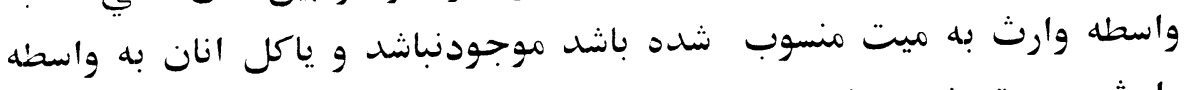

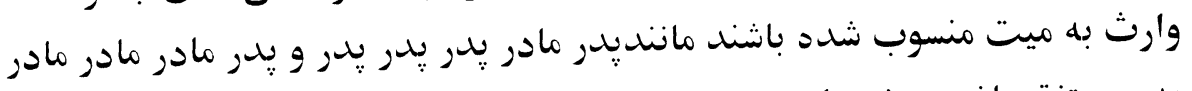

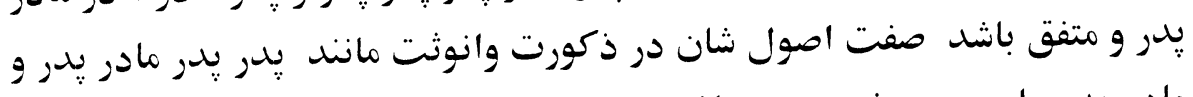

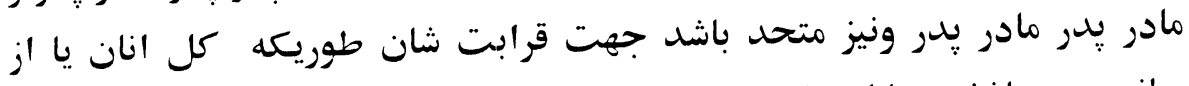

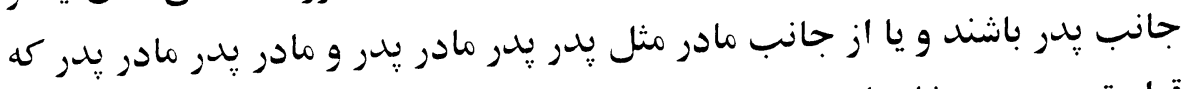

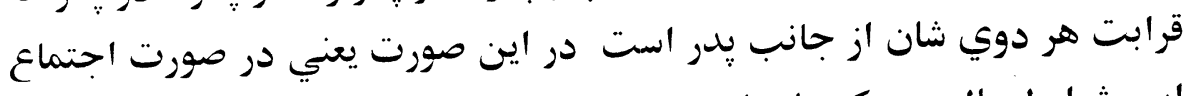

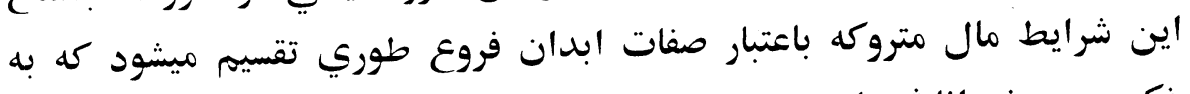

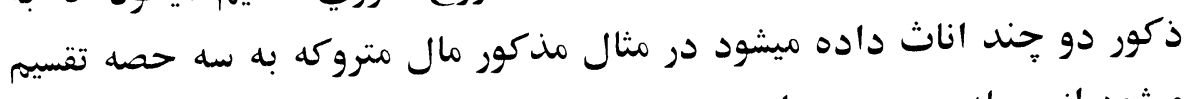

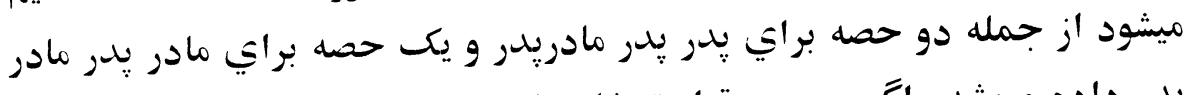

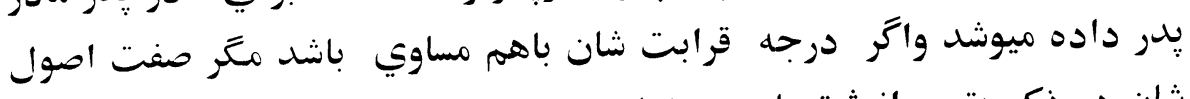

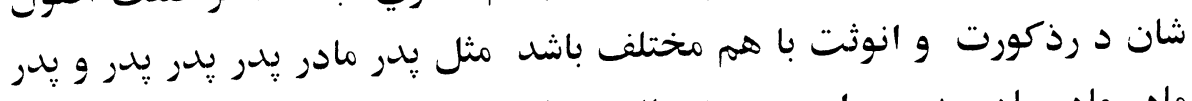

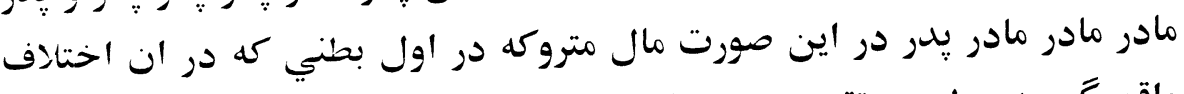

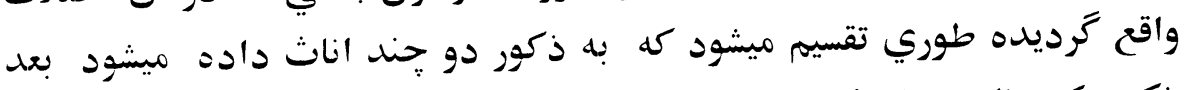

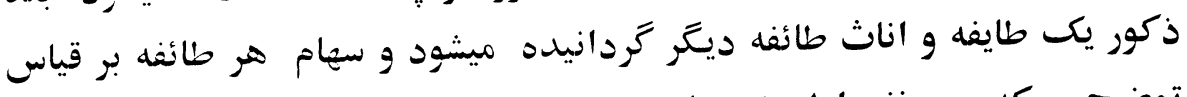

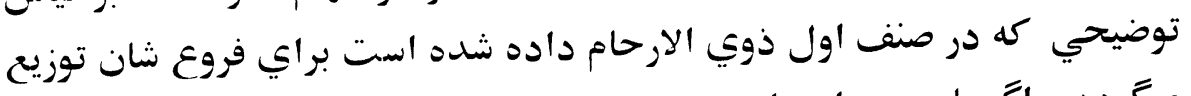

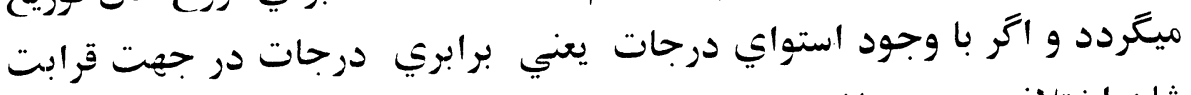

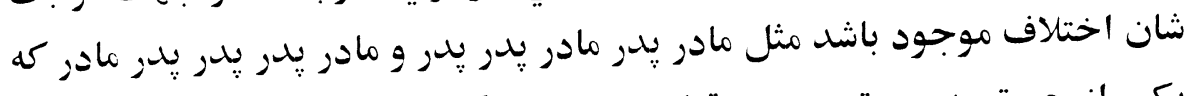

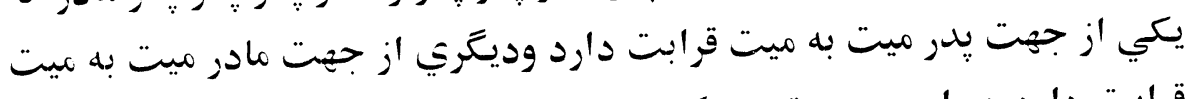

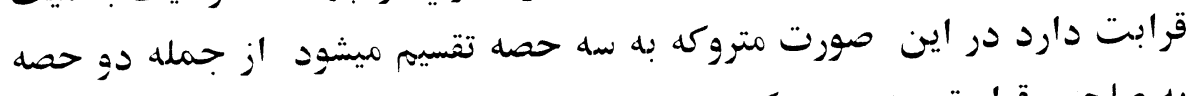

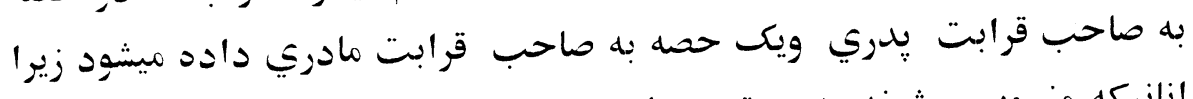

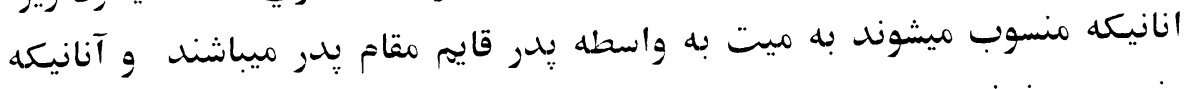

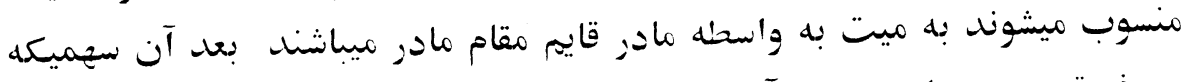

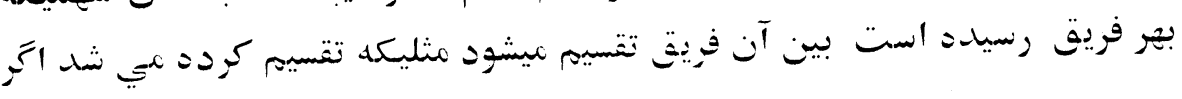


متحد مي بود جهات قرابت انان جنانكه ميت دو جد فاسد يكي از طرف يدر يدرش

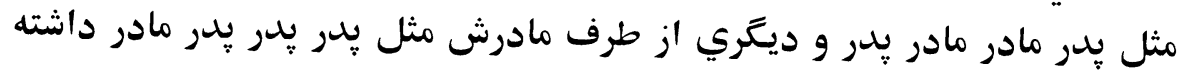

باشد

\section{فصل_ صنف سوم}

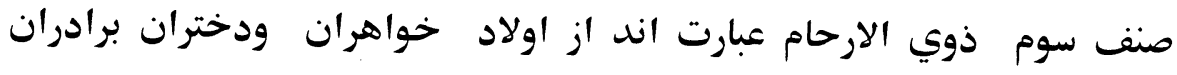

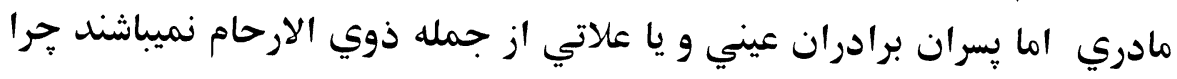
كه انان عصبه اند

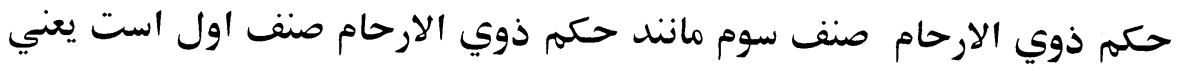

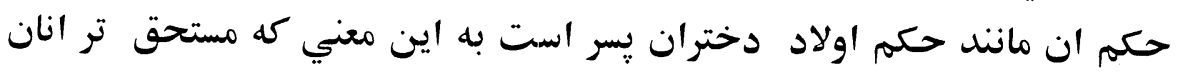

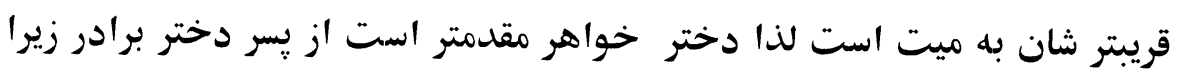
كه دختر خواهر به ميت قريبتر ميباشد

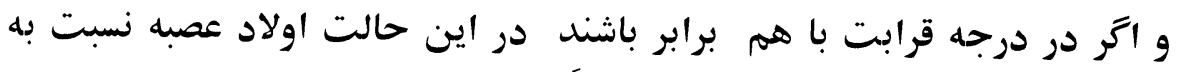

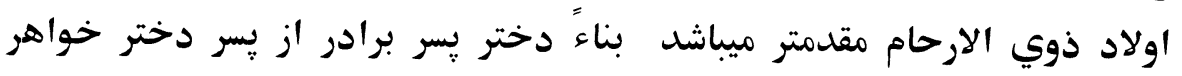

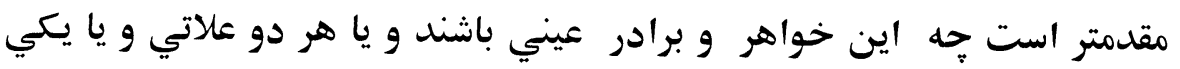

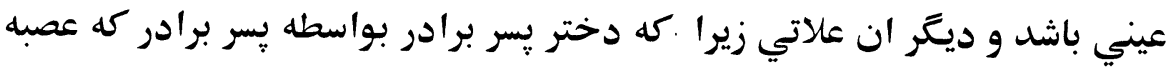

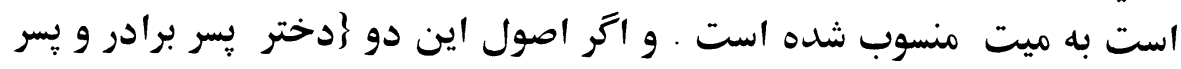

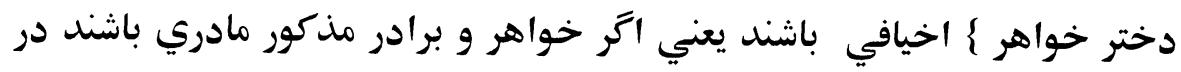

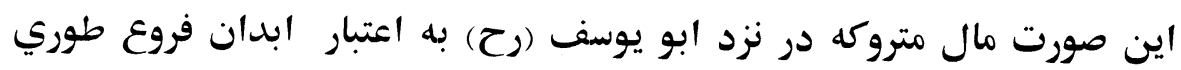

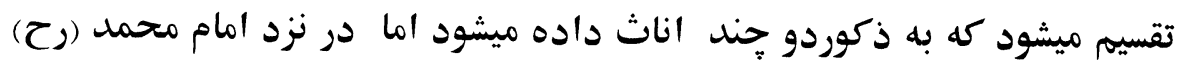

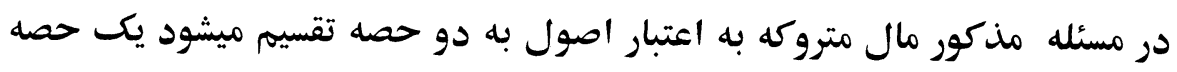

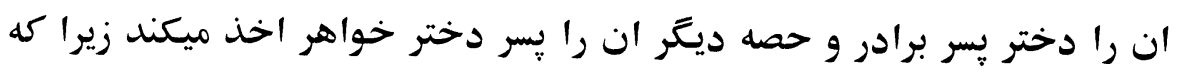

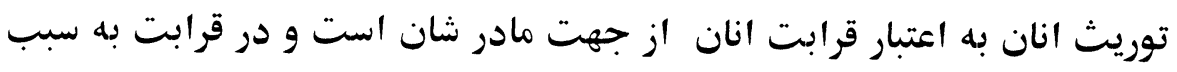

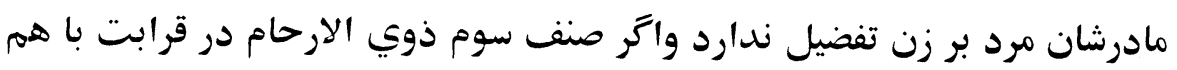

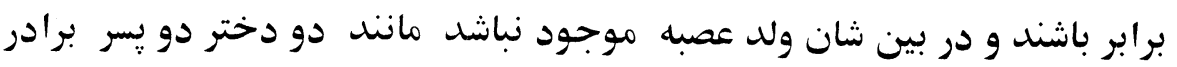




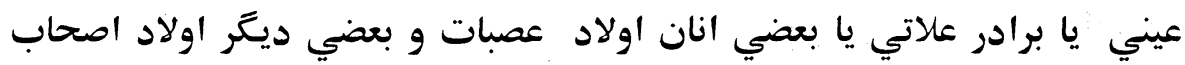

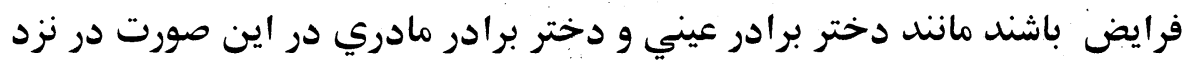

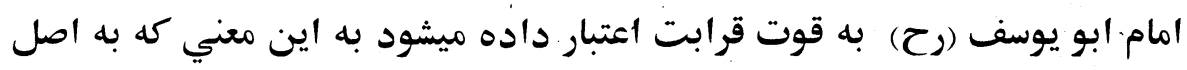

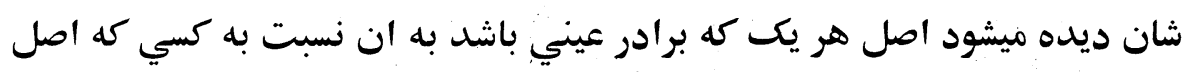

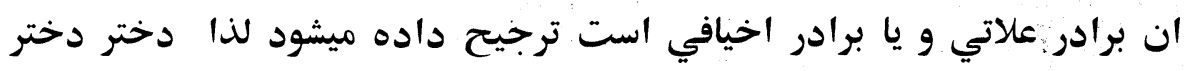

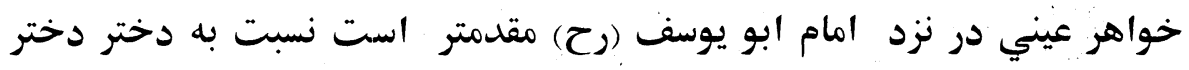

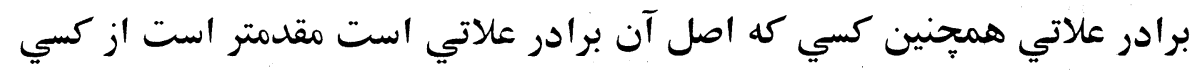

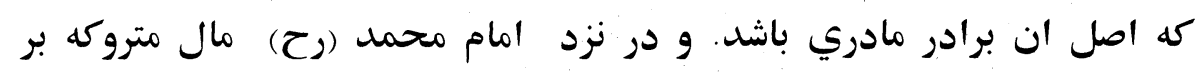

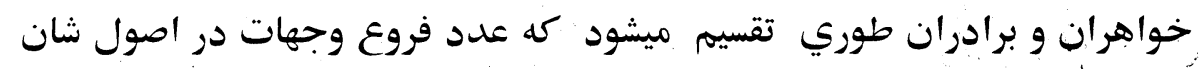

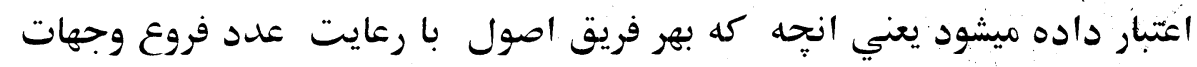

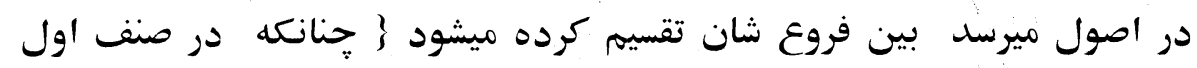

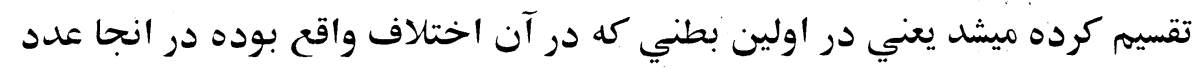

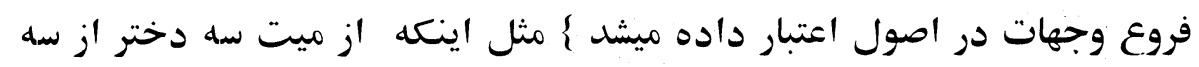

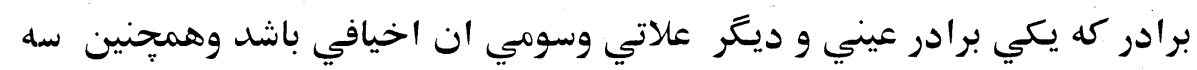

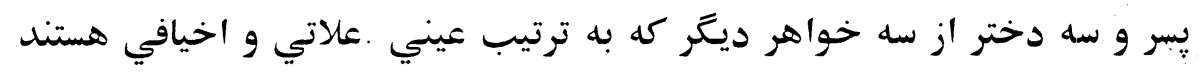

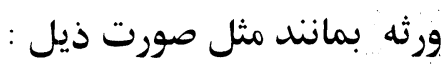
اصل r r = تصحيح

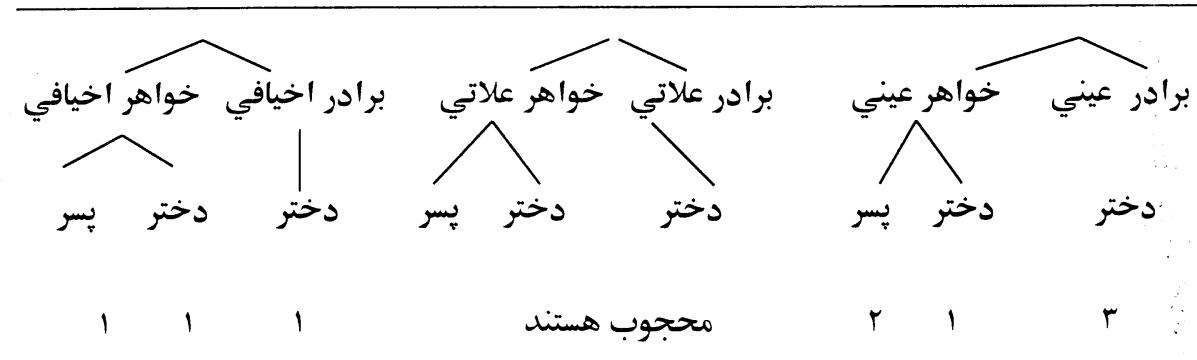


در نزد امام ابو يوسف (رح) تما م مال متروكه در صورت فوق اول بين فروع

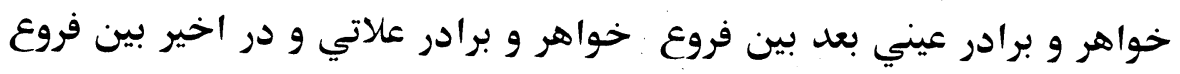

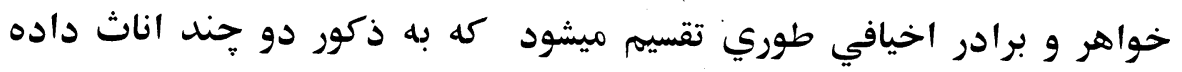

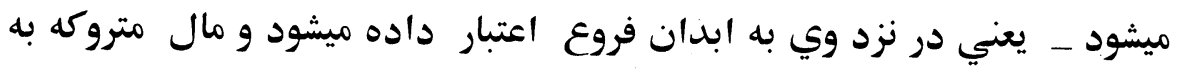

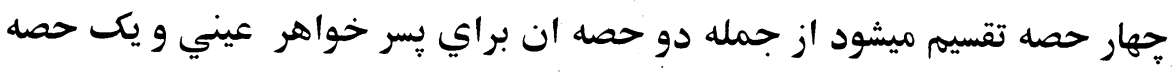

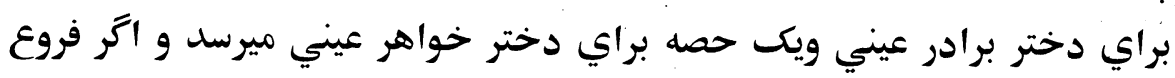

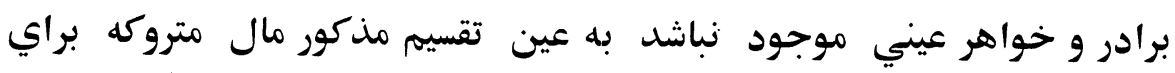

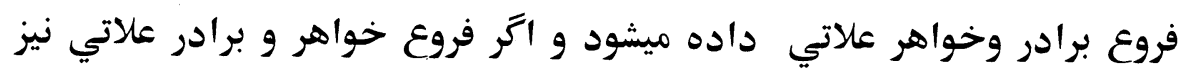

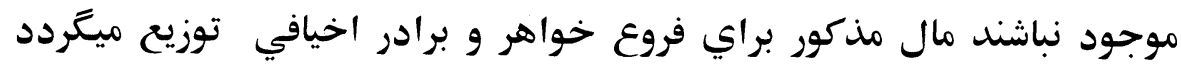

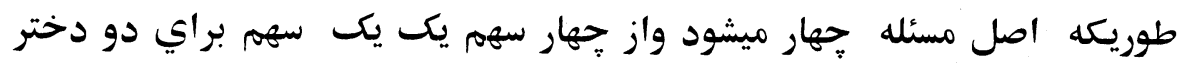

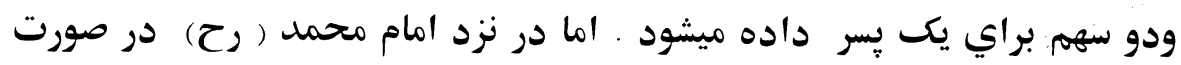

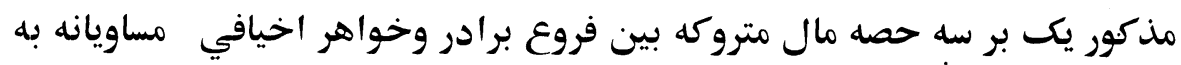

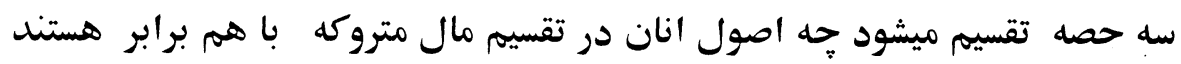

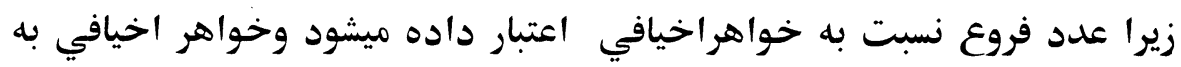

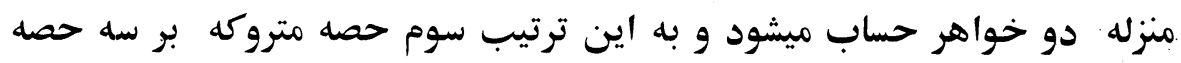

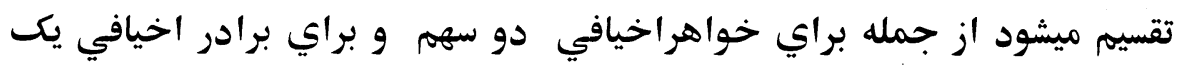

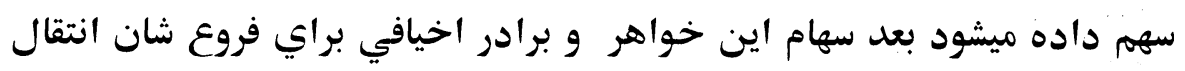

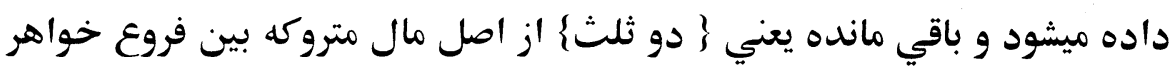

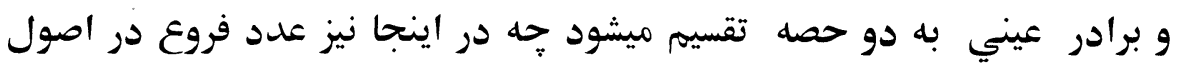

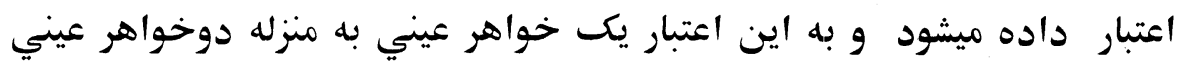

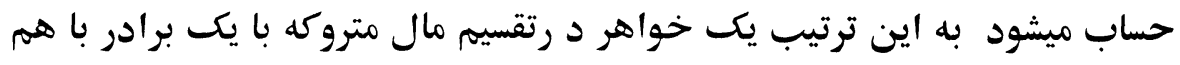

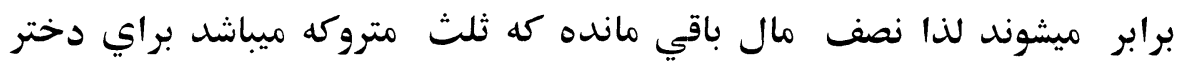

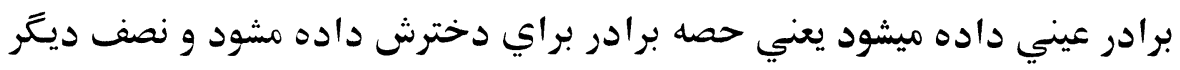

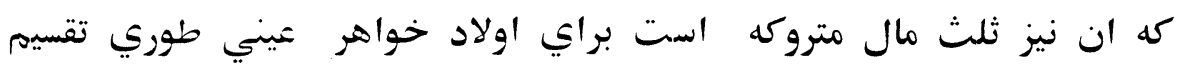


ميترددكه براي ذكور دو جند اناث داده ميشود جه در اصل شان اختلاف

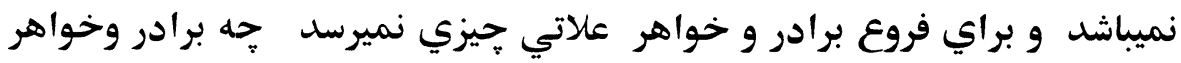

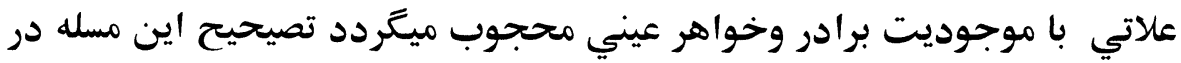

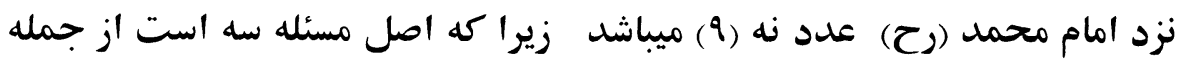

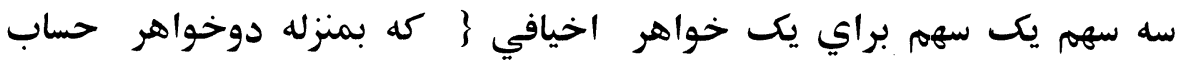

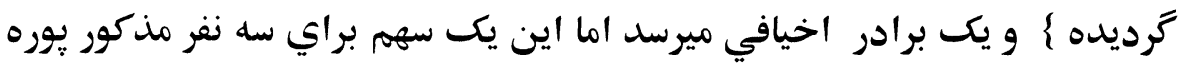

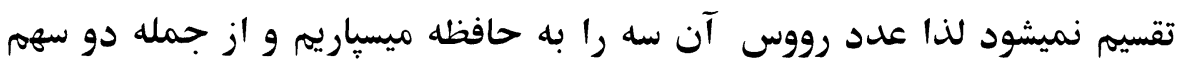

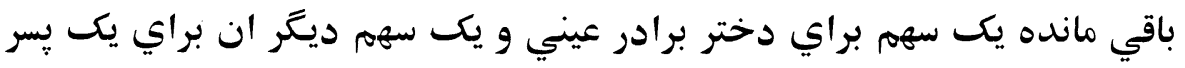

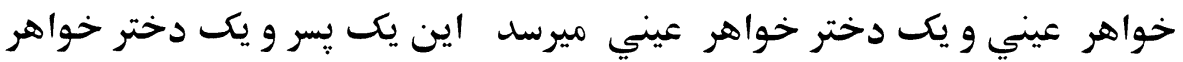

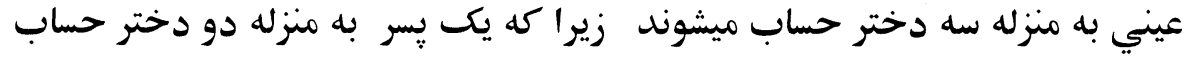

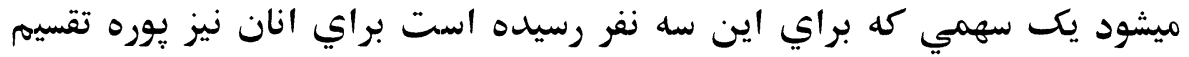

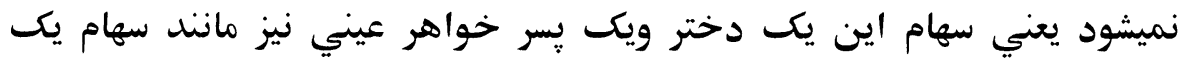

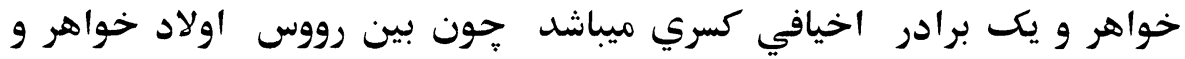

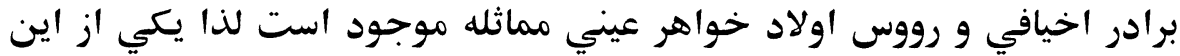

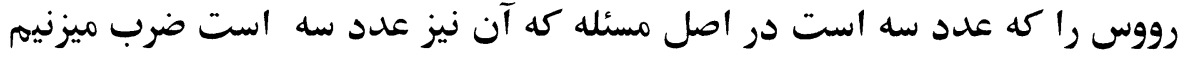
حاصل آن كه نه(9) ميشود تصحيح مسئله كه ان نيز عدد سه است ضرد اله إب ميزنيم

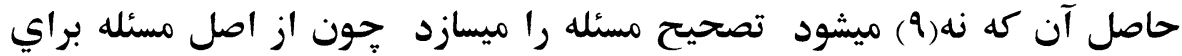

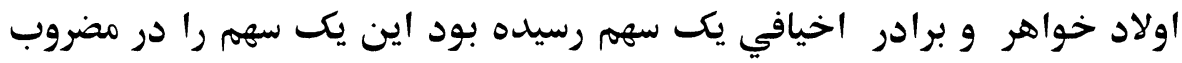

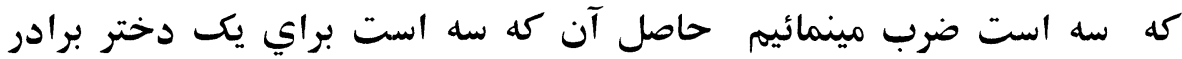

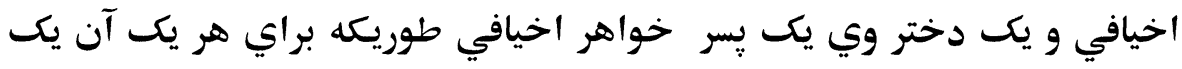

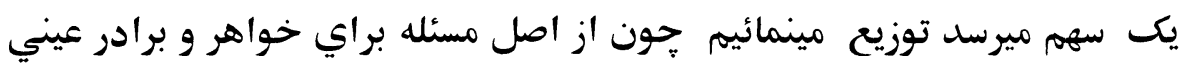

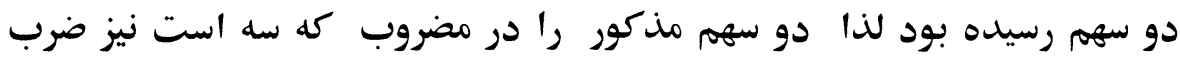
مينمائيم حاصل ان كه شش سهم ميشود از ان سه سهم را براي دختر برادر عيني 
و دو سهم آن را براي يسر خواهر عيني و يك سهم را براي دختر خواهر عيني توزيع ميكنيم

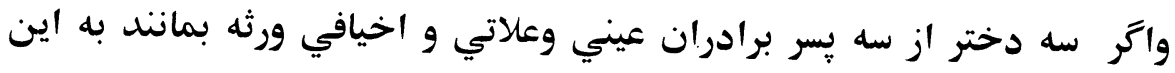

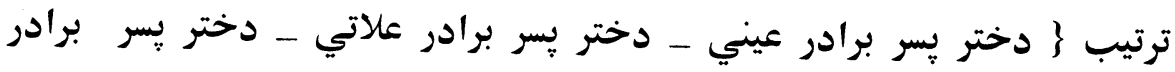

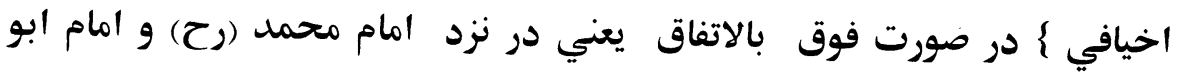

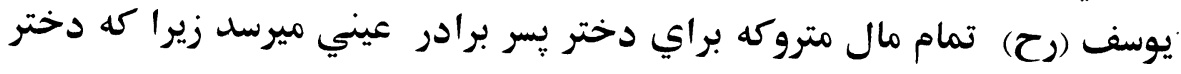

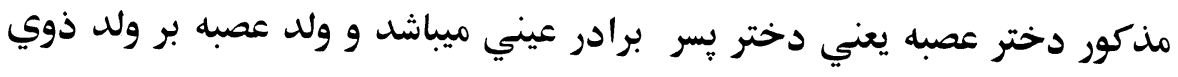

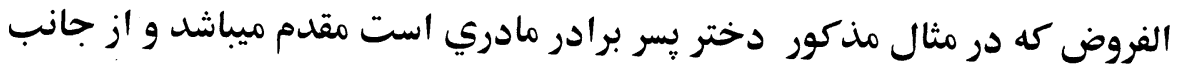

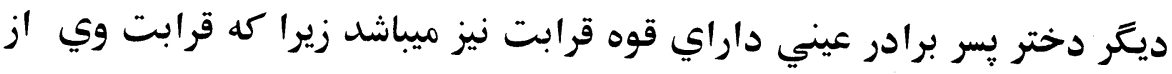

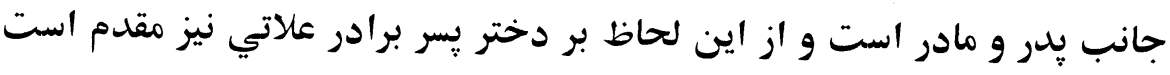

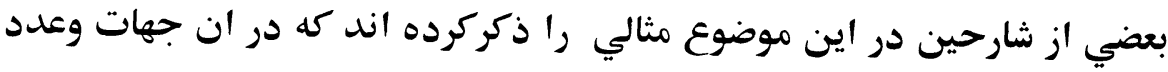

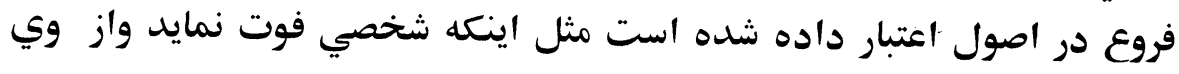

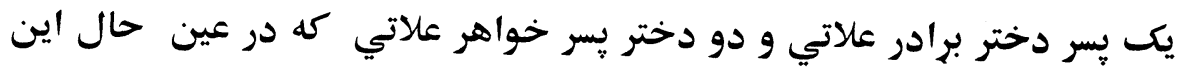

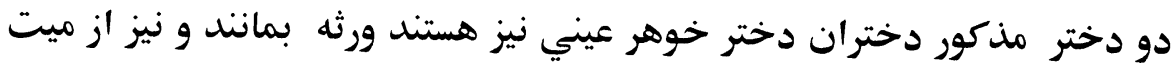

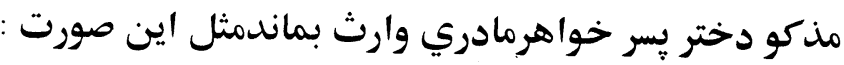

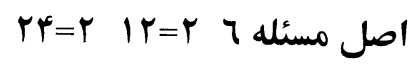

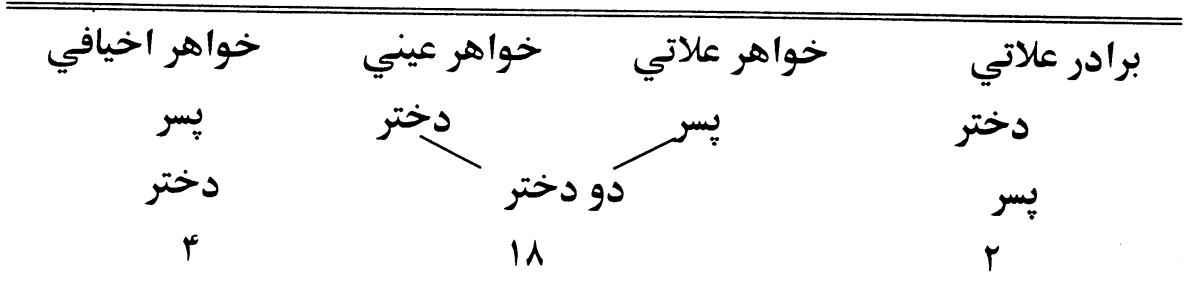

در نزد ابو يوسف (رح) تمام مال متروكه براي دو دختر دختر خواهر عيني

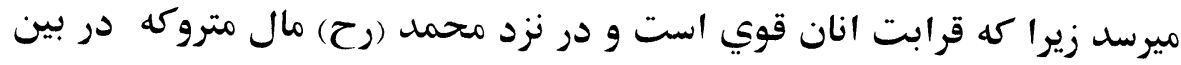


خواهران و برادران در اصول تقسيم ميشود ودر تقسيم مال بين اصول به جهات

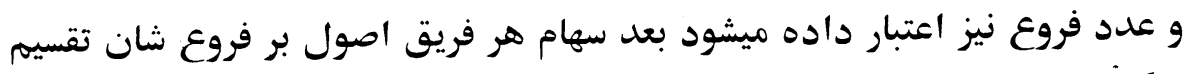

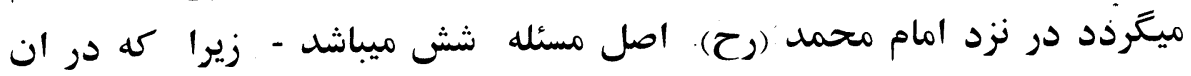

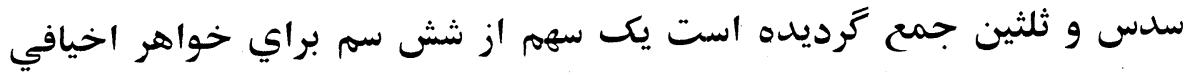

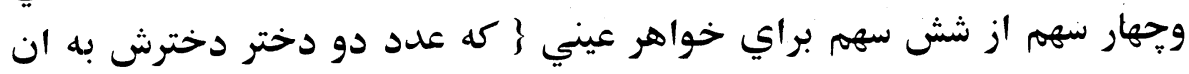

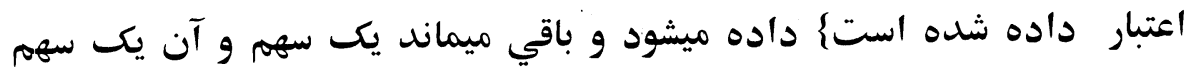

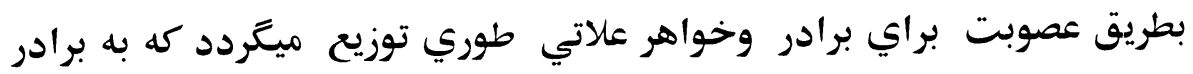

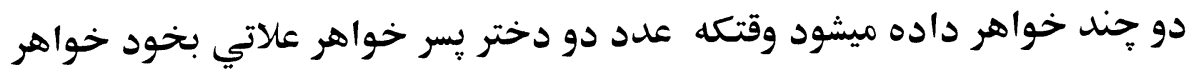

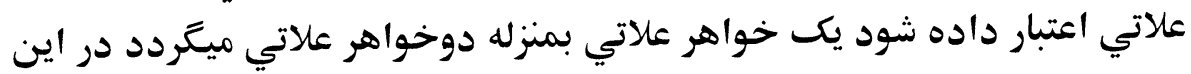

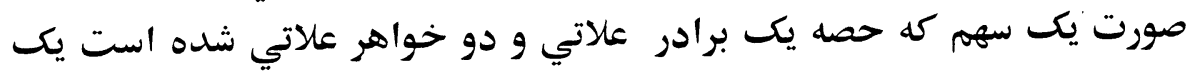

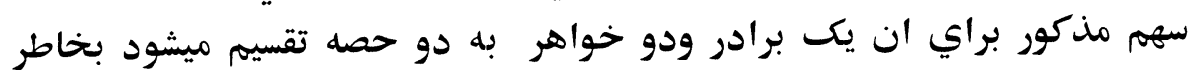

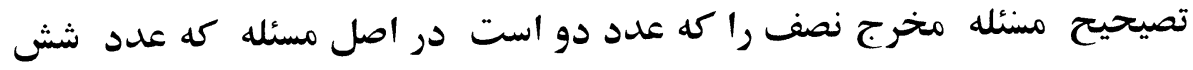

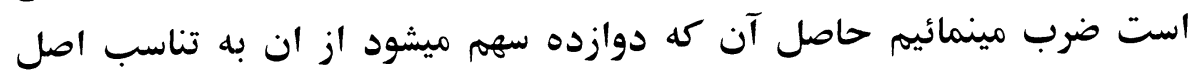

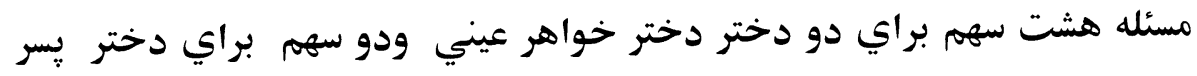

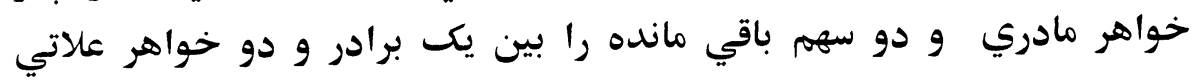

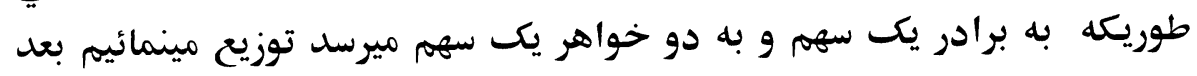

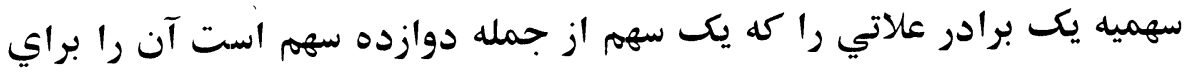

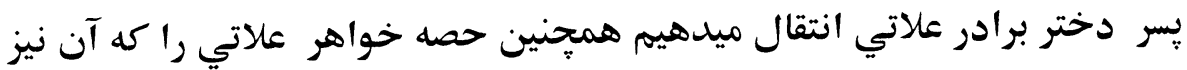

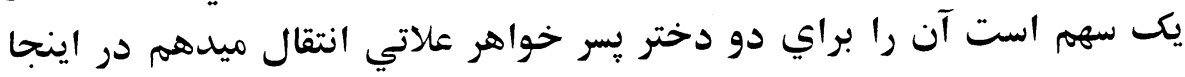

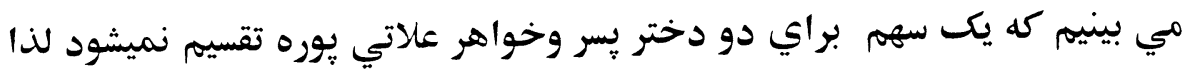

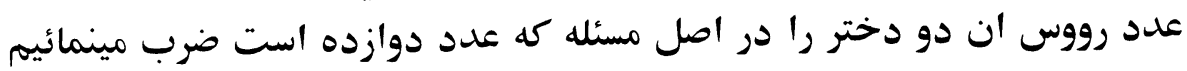

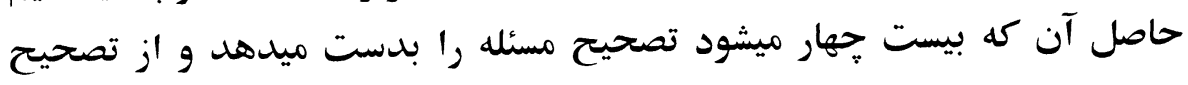

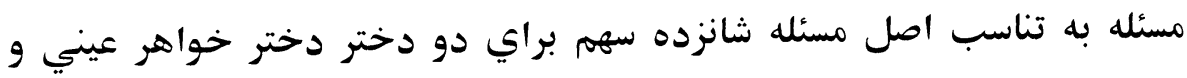

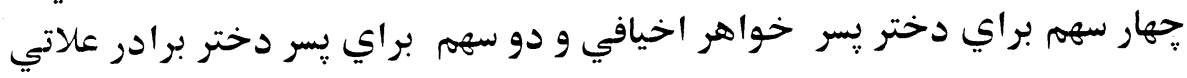




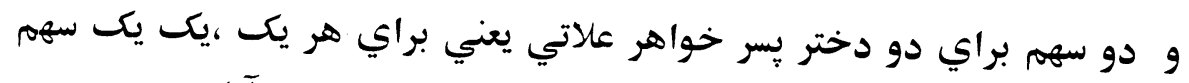

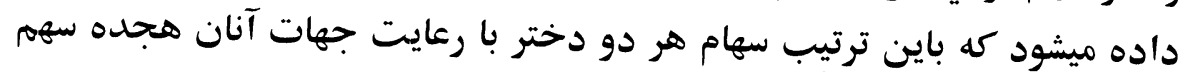

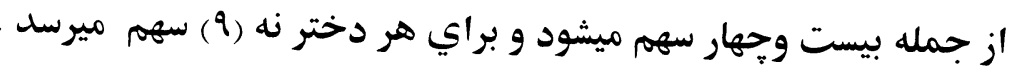

\section{فصل صنف :حهارم}

صنف جهارم عبارت از آن ذوي الارحام است كه منسوب ميباشد به پيدر يدر و

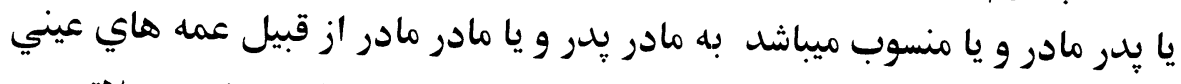
، علاتي و اخيافي وكاكاهاي مادري و ماما هاو خاله هاي عيني ، علاتي و و

حكم اين صنف اين است كه اتر يكت نفر از اين صنف طور منفرد وارث باشد

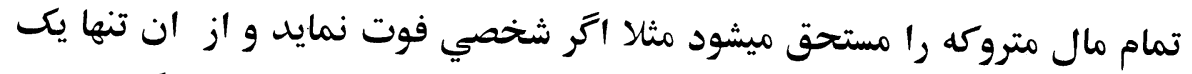

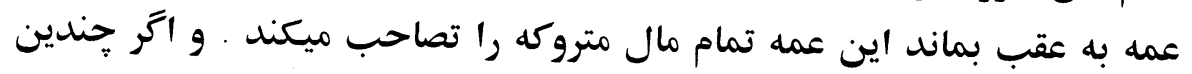
نفر از صنف مذكور از وي به عقب بماند در اين صورت ديده ميشود اترحيز

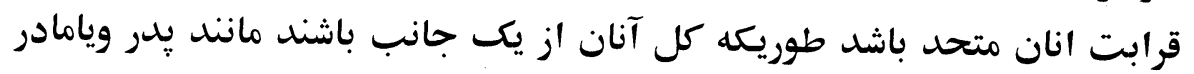

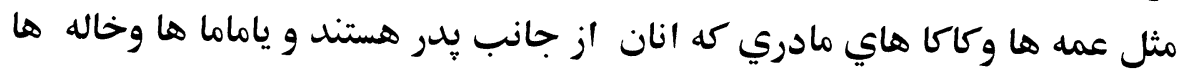
كه آنان از جانب مادر هستند يعني حيز هان مان متحد است در در اين صورت بالاجماع به قوت قرابت ترجيح داده ميشود به اين معني كه كسي كهي كه از اينان

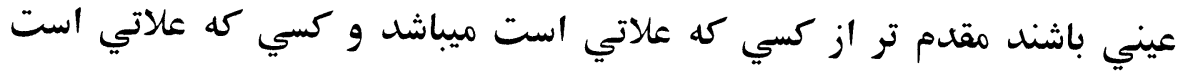
مقدم تر از كسي ميباشد كه اخيافي است زيرا كه قرابت از دو جانب قويتر است. و همحنين قرابت از جانب يدر قويتر است از قرابت جانت جانب مادر

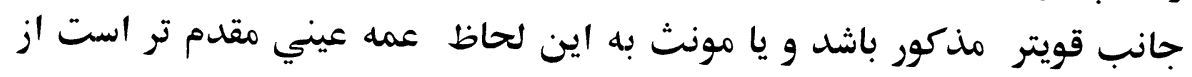

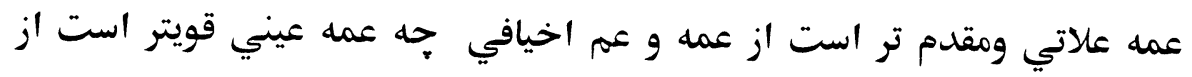
جهت قرابت و لذا تمام مال متروكة را عمه عيني تصاحب مينمايد وهمحنين

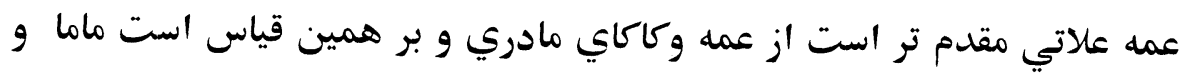

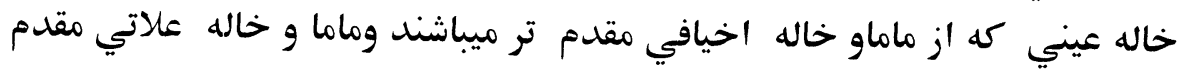




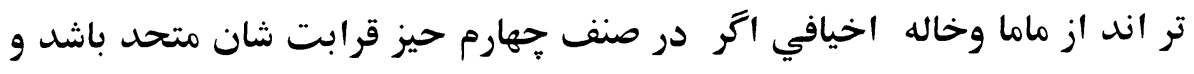

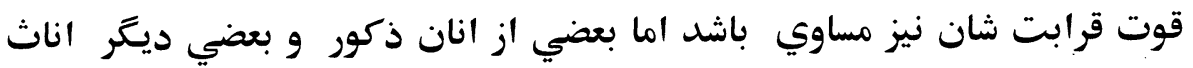

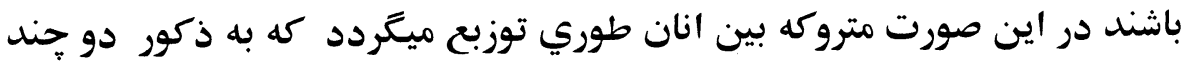

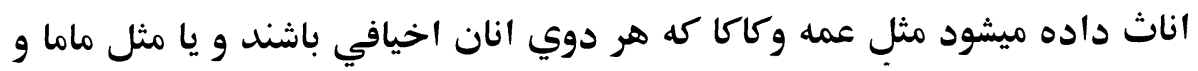

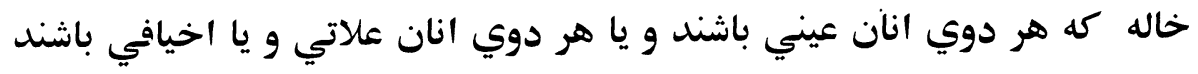

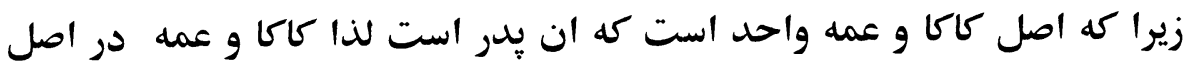

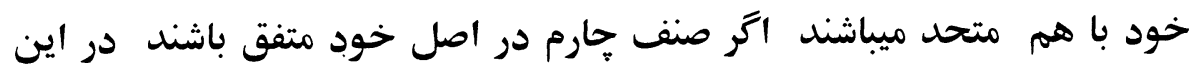

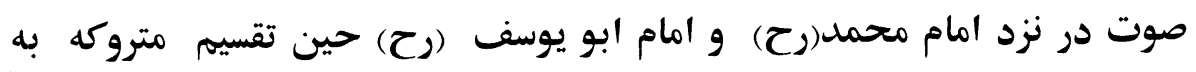

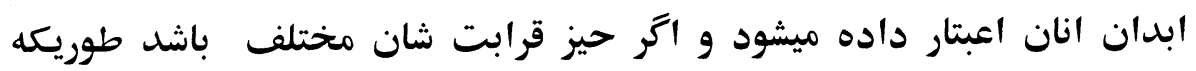

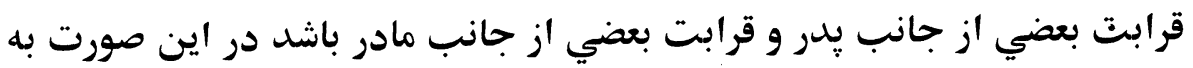

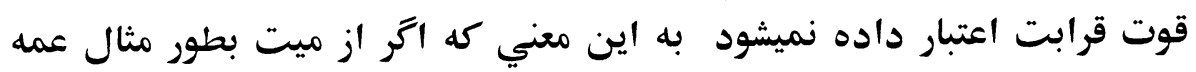

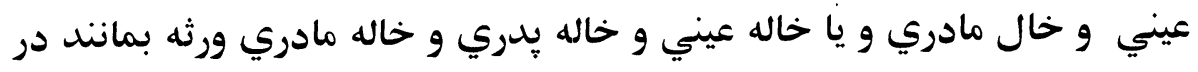

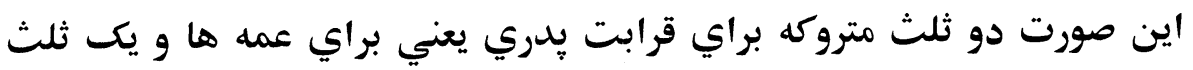

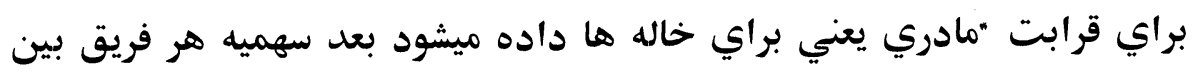

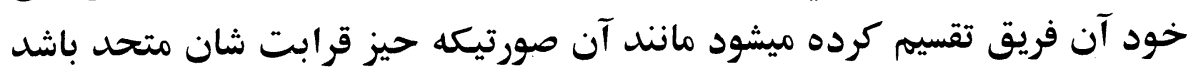

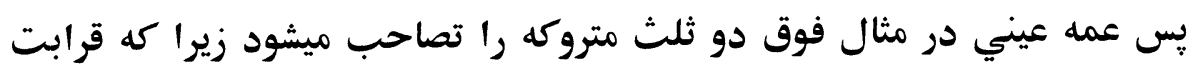

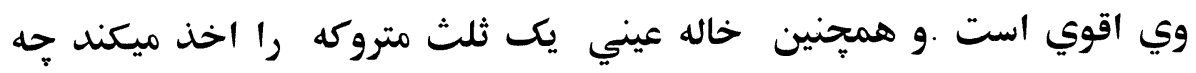

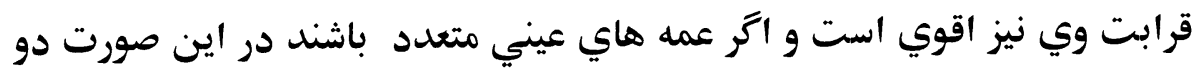

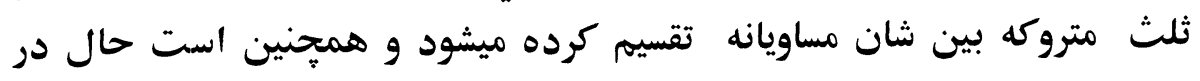

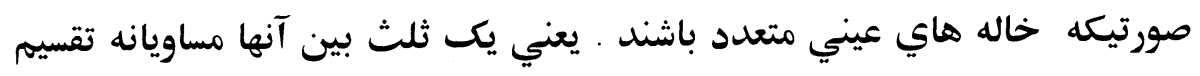
كرده ميشود.

\section{فصل اولاد صنف حهارم}

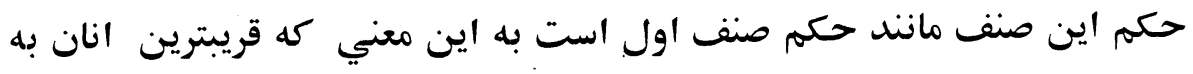

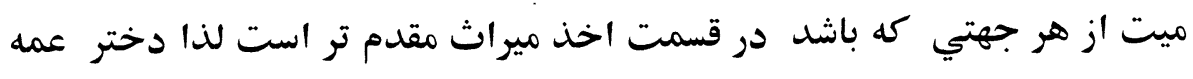


يا گِر عمه مقدم تر است از دختر دختر عمه و از يسر دختر عمله و از دختر پسر

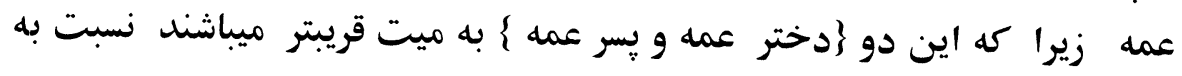
آنان، و دختر خاله و بسر خاله نسبت به دختر دختر خاله و ويسر دختر خاله مقدم

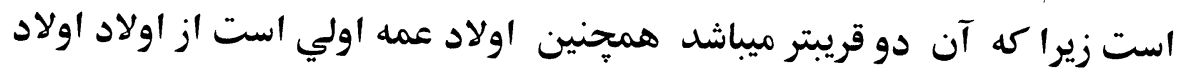

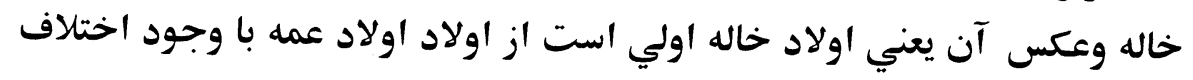

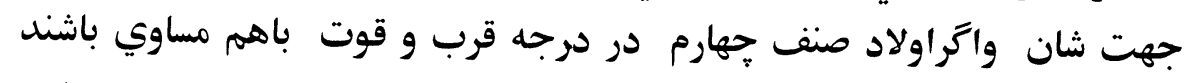

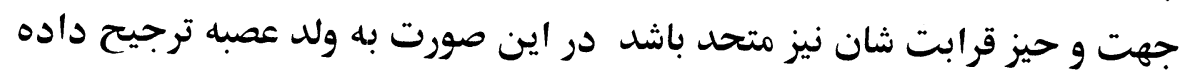

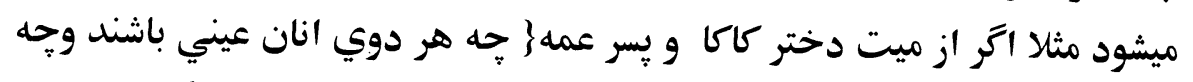

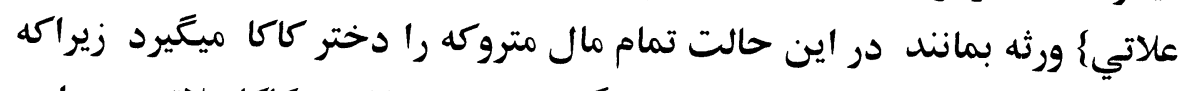

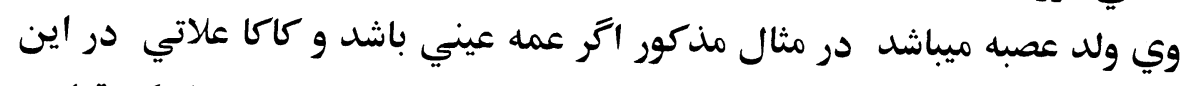

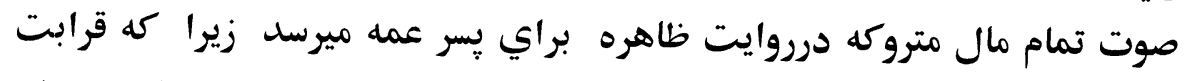

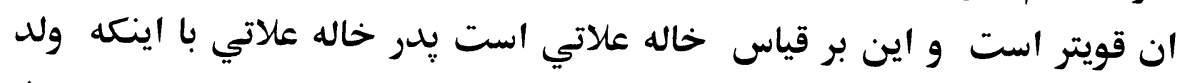

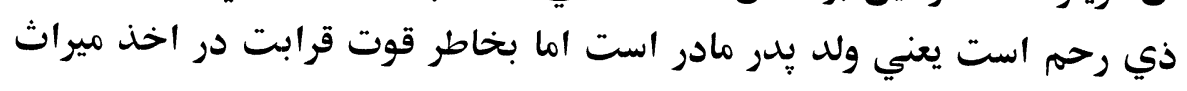
مقدم تر است از خاله اخيافي با اينكه خاله اخيافي ولد وارث ميباشد يعني ولد

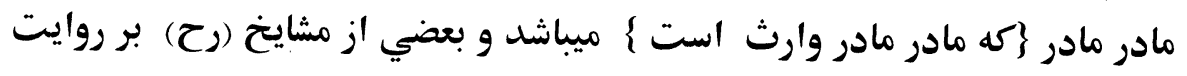

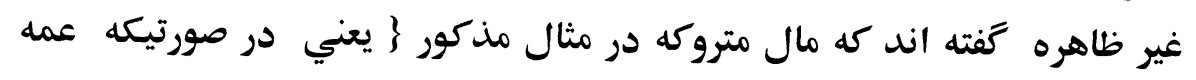

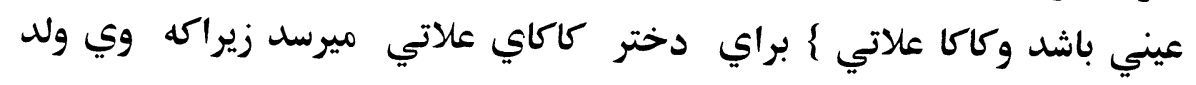

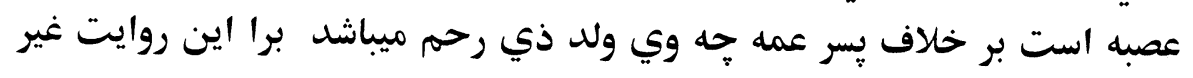

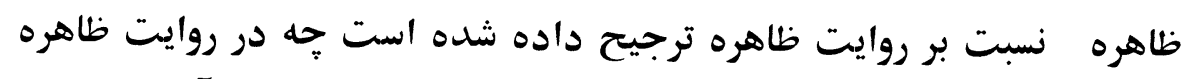

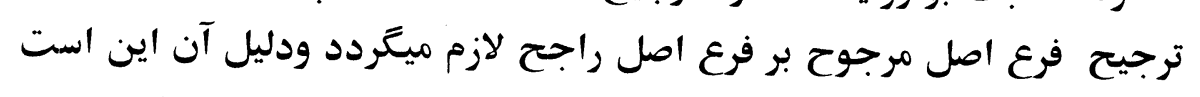

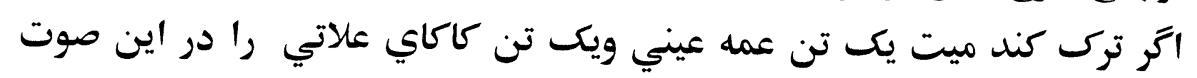

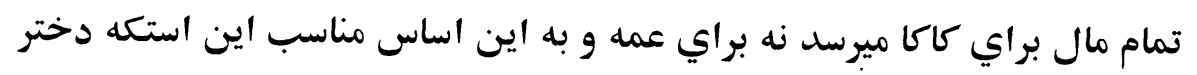

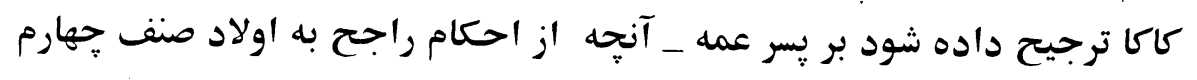

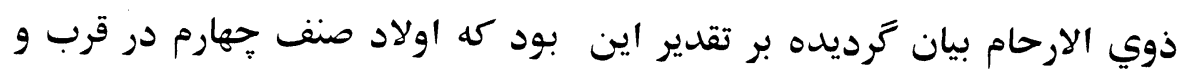

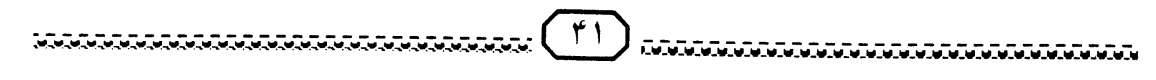


اتحاد حيز قرابت با هم برابرباشند و اكر در درجه قرابت باهم برابر باشند اما

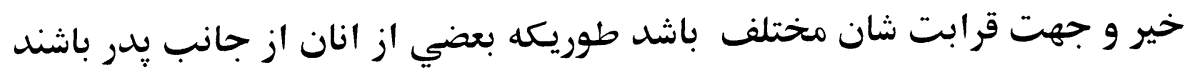

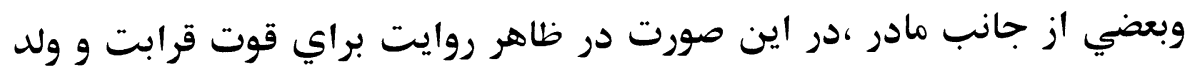

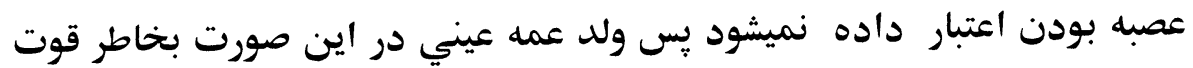

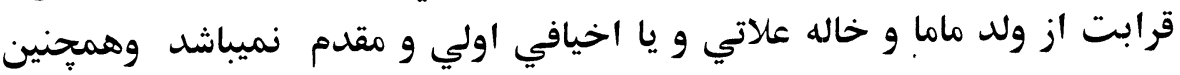

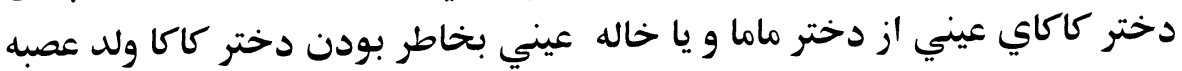

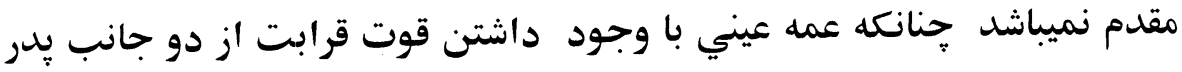

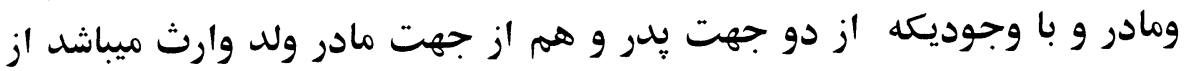

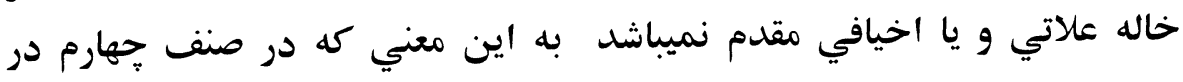

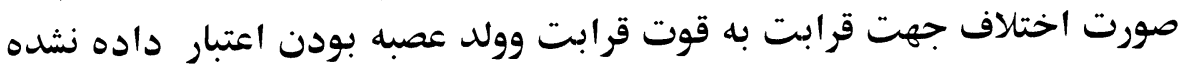

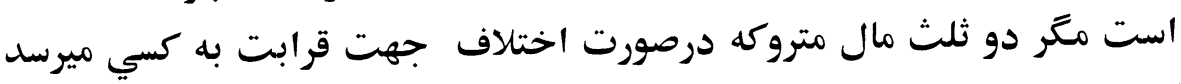
كه قرابت وي به ميت از جانب يدر ميت باشد به اين معني كه وي قائم مقام يدر

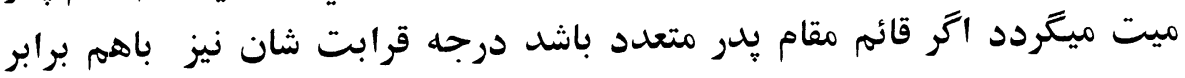

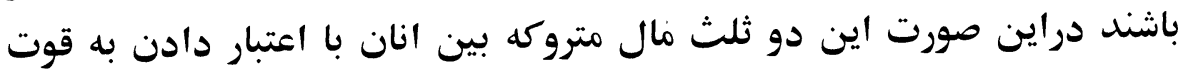

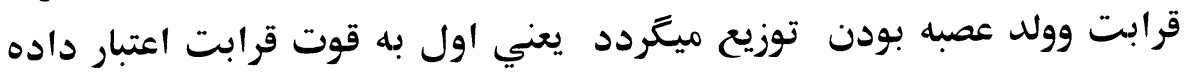

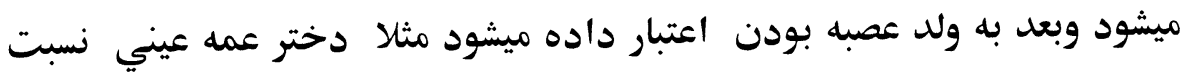
به دختر عمه علاتي و يا اخيافي ترجيح داده ميشود و همجنين دختر كاكاي

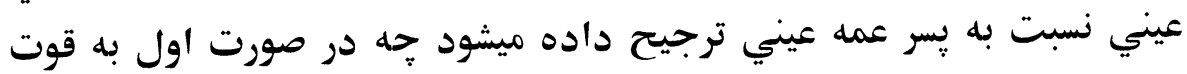

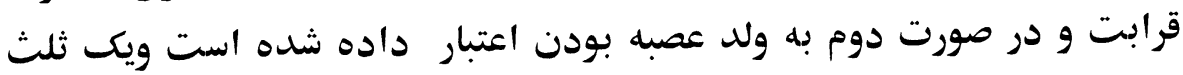

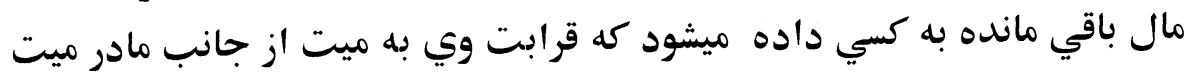
ميباشد يعني وي قائم مقام مادر ميت ميشود . در اقرباي جانب مادي مادر ميت ماديت مانند

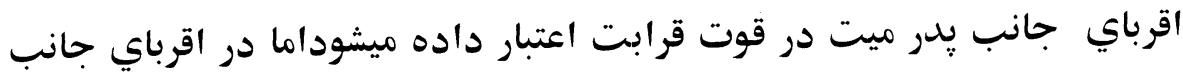

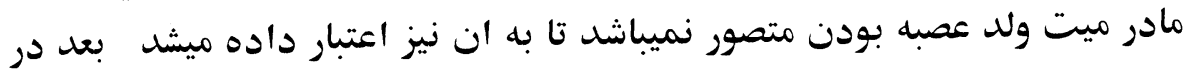

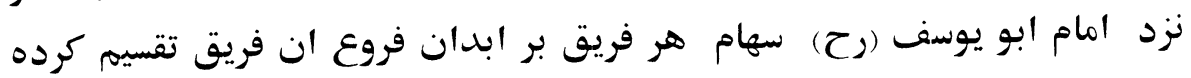


ميشودو در اين تقسيم به عدد جهات در فروع نيز اعتبار داده ميشود و در نزد اما

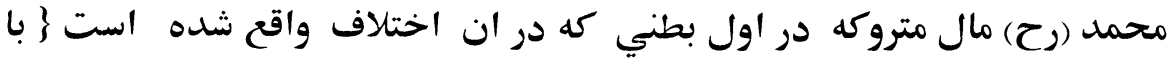

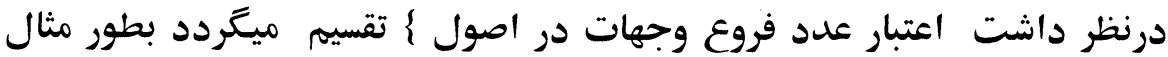
اتر فرض كنيم كه شخصي فوت كرد و از وي دو يسر دختر عمه علاتي و دو دختر يسر عمه علاتي كه در عين حال دو دختر دختر كاكاي علاتي نيز ميباشد يا دو دختر دختر خاله علاتي و دو يسر يسر خاله علاتي كه درعين حال دو يسر دختر ماماي علاتي نيز ميباشد ورثه مانده اند مثل اين صورت :

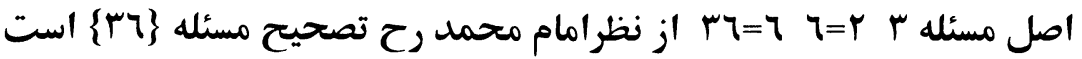

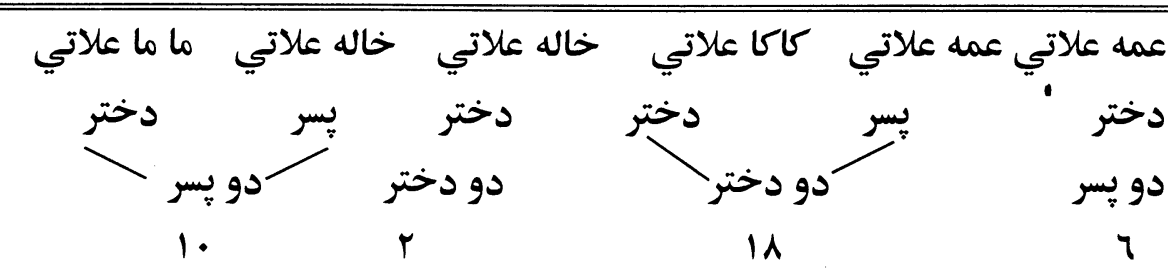
اصل مسئله در صورت متذكره فوق سه ميباشد دو حصه آن به قرابت پبري و يكس حصه آن به قرابت مادري ميرسد ليكن در نزد امام ابو يوسف (رح)

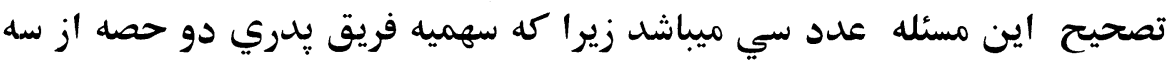
حصه است اما اعداد فريق يدري وقتيكه اعتبار كرده شود عدد جهات در فروع

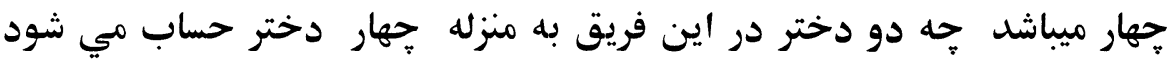
يعني دو دختر از جهت يسر عمه علاتي ودو دختر از جهت دختر كاكاي علاتي

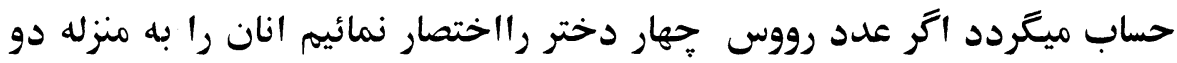
״سر حساب ميكنيم به اين ترتيب در اين فريق جهار يسر ميباشد براي اين جهار

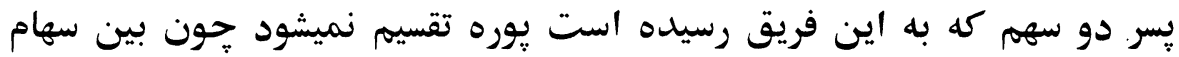

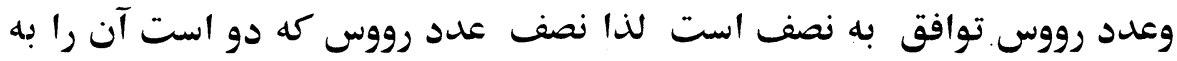
حافظه نتاه ميكنيم و براي فريق مادري يك سهم از سه سهم رسيده بود اعدا دفريق مادري با اعتبار دادن عدد جهات در فروع ينج است زيراكه دو يسر در 
اين فريق به منزله جهار يسر حساب ميشود يعني دو يسراز جانب بِ

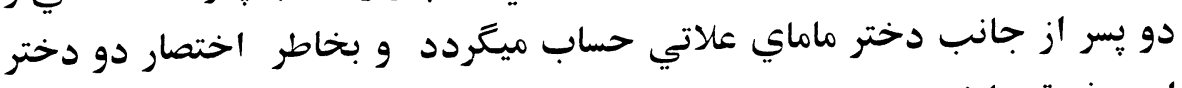

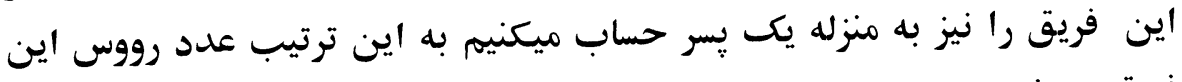

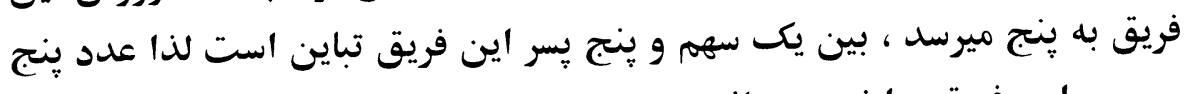

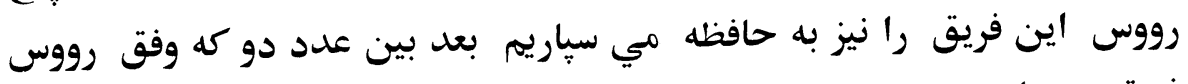

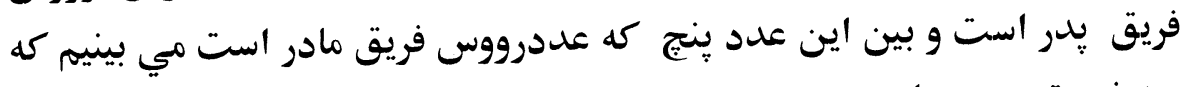

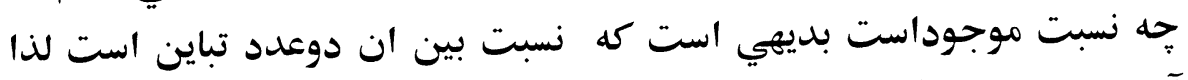

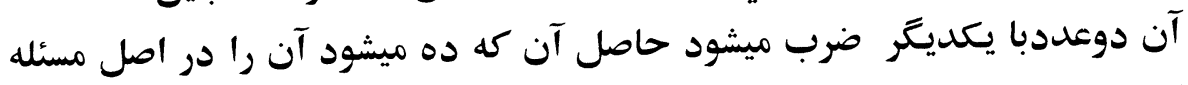
كه عدد سه است ضرب مينمائيم حاصل آن كه سي ميشود تصحيح مسئله رأدرد

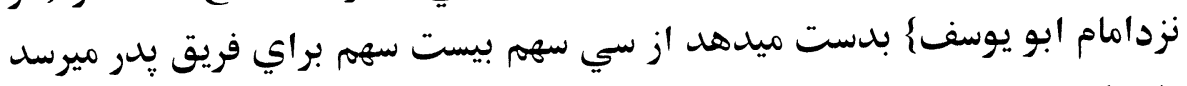

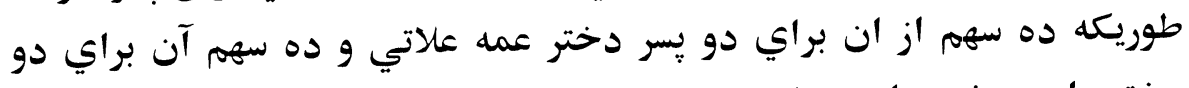

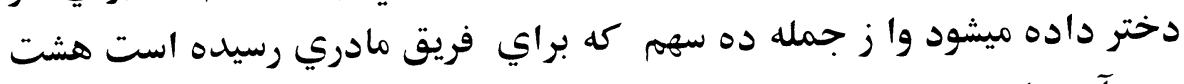

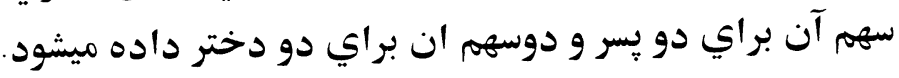

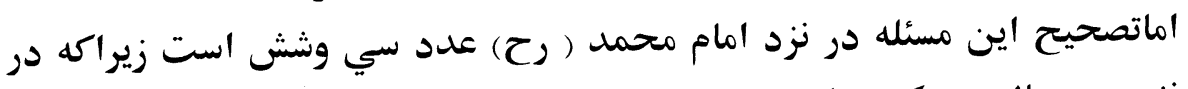

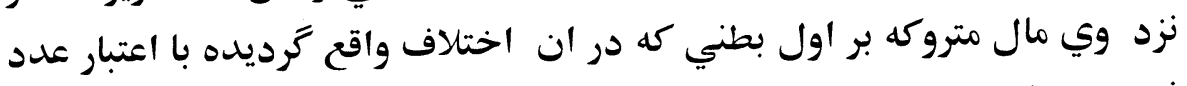

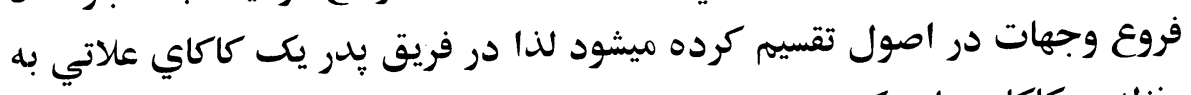

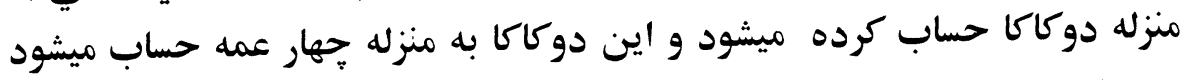
وهر يك از عمله هاي علاتي به منزله دو عمه حساب ميشودكه به اين ترتيب

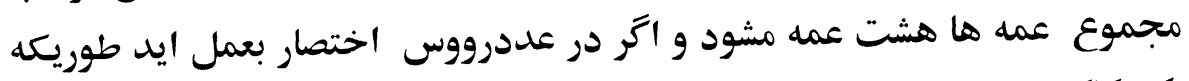

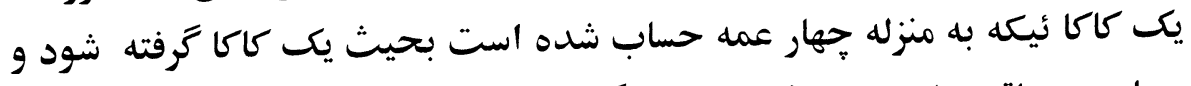

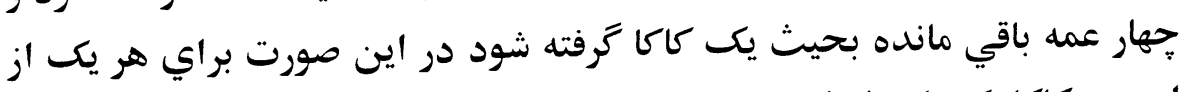

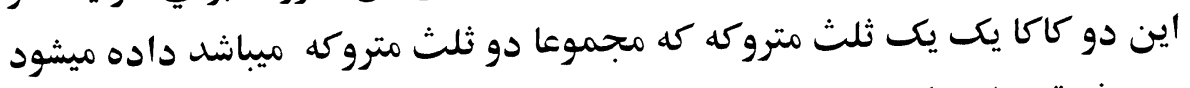
و در فريق مادر يكس ماماي علاتي به منزله دو ماما حساب ميشود و اين دو ماما بـ به ماله

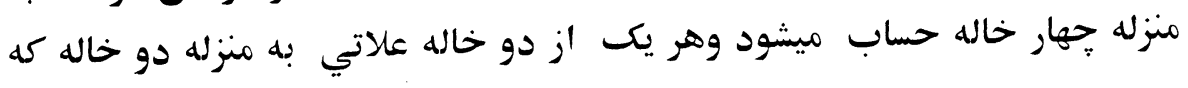


مجموعا جهار خ خاله شود حساب ميكردد بنا بر اعتبار عددفروع وجهات در اصول

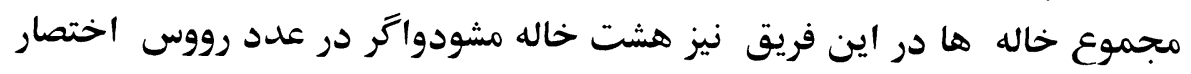

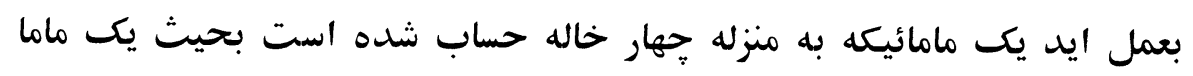

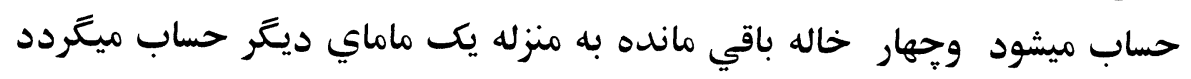

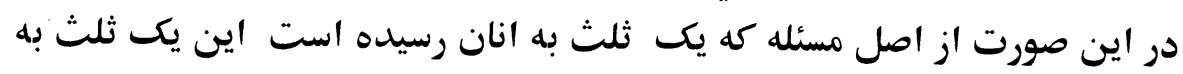

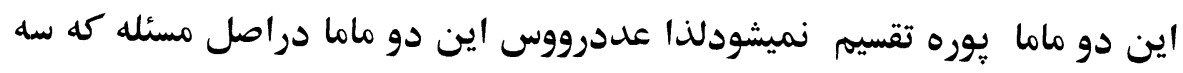

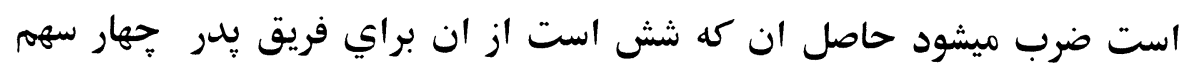

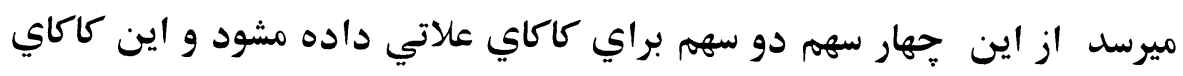

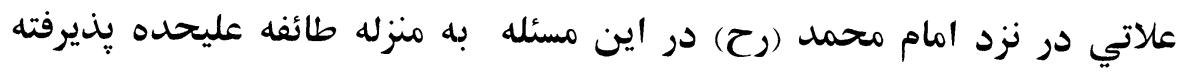

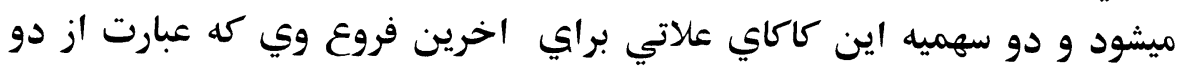

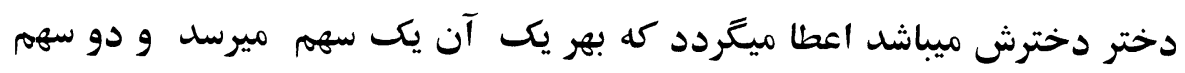

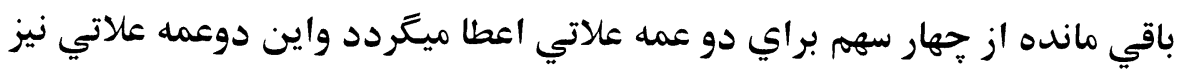

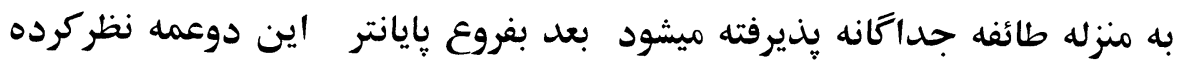

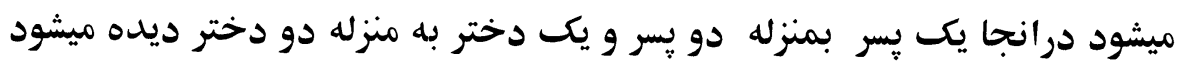

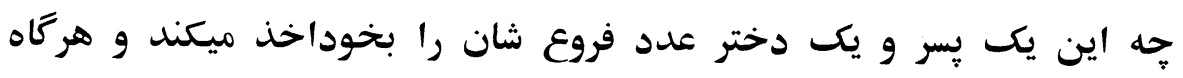

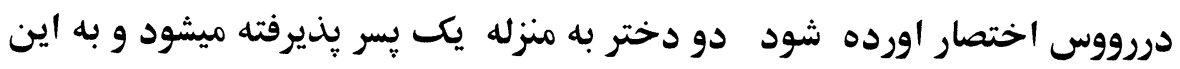

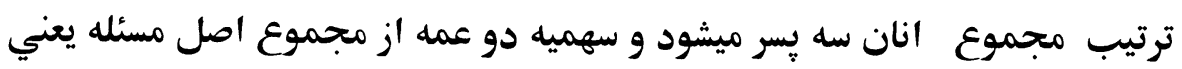

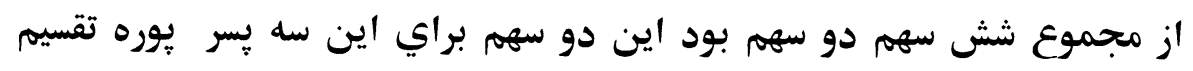

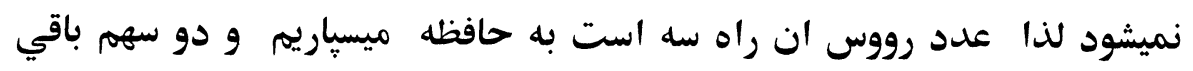

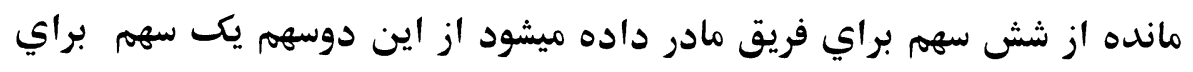

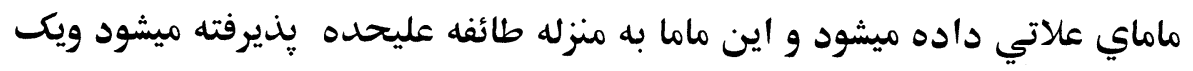

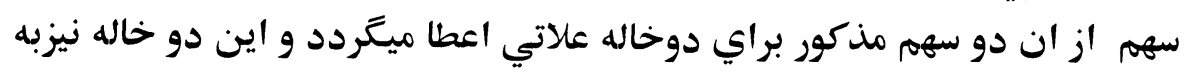

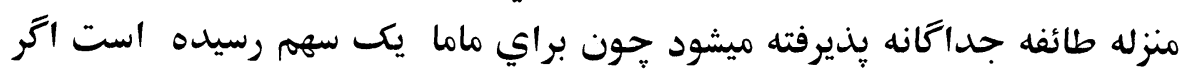

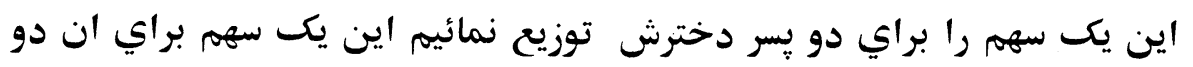




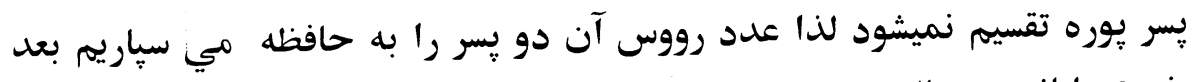

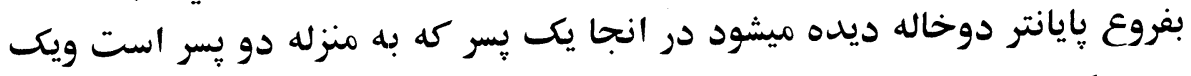

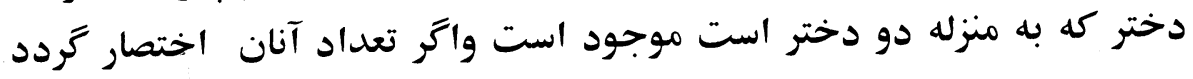

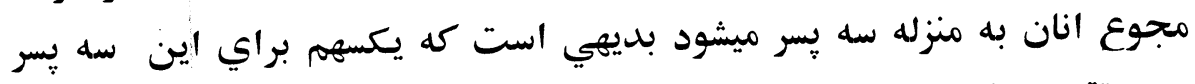

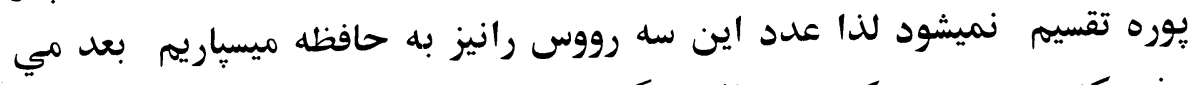

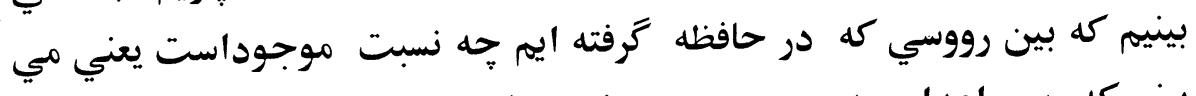

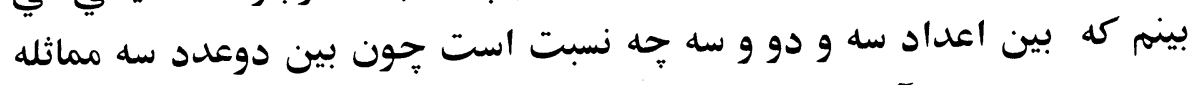

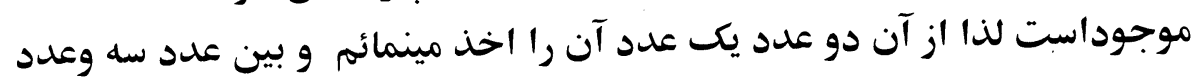

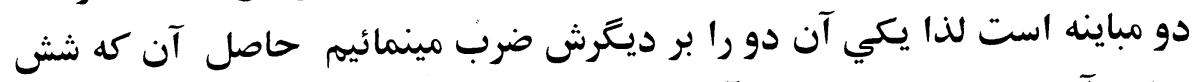

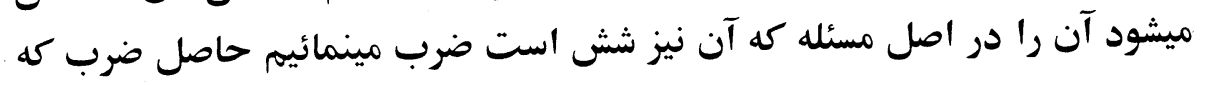

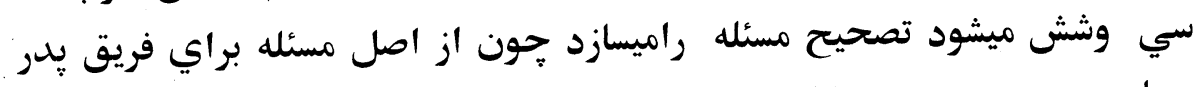

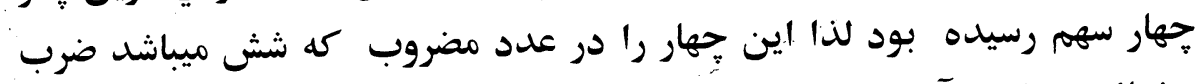

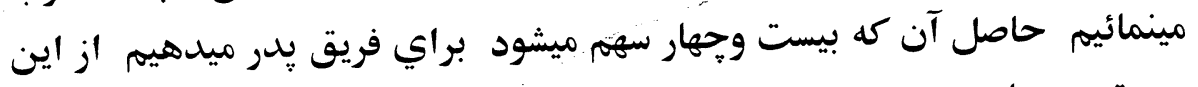

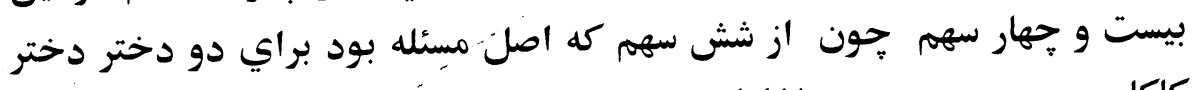

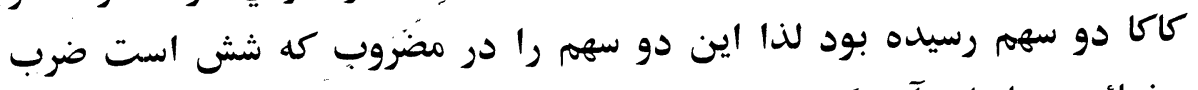

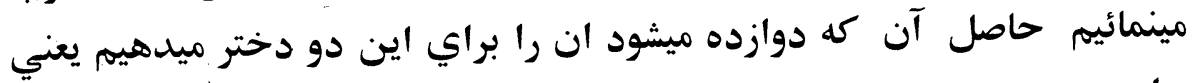

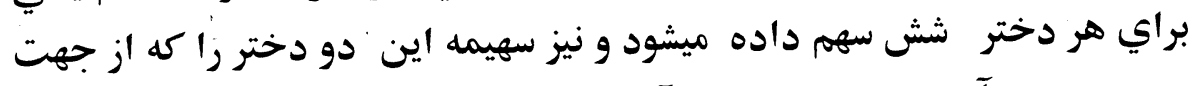

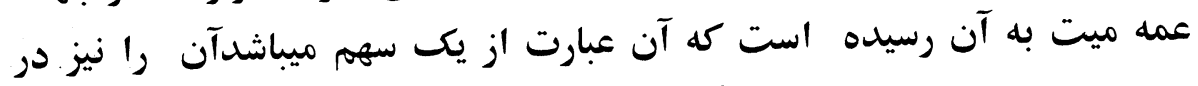

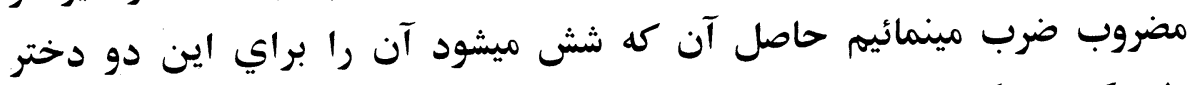

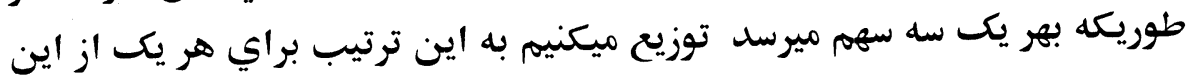

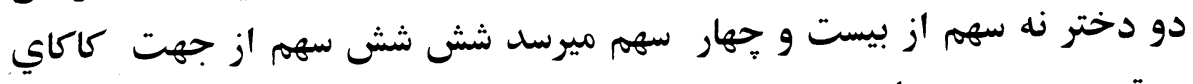

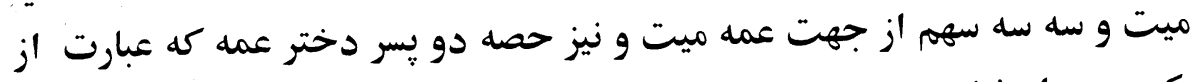

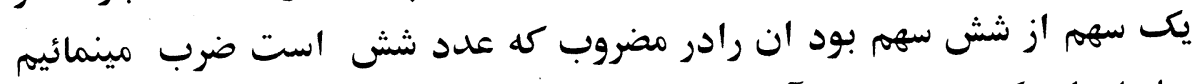

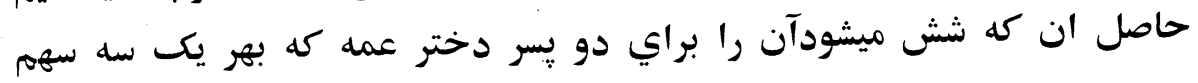




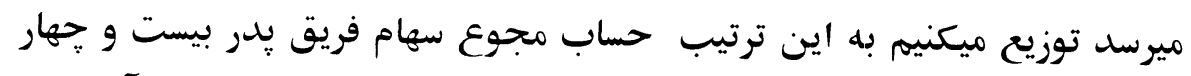

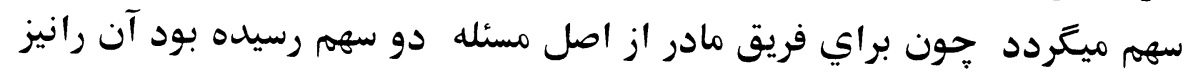

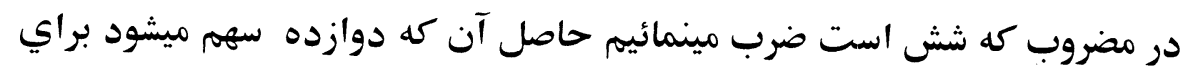

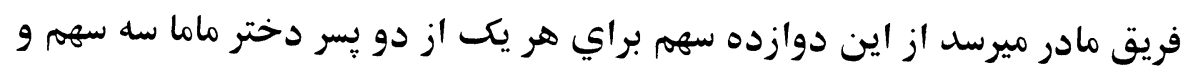

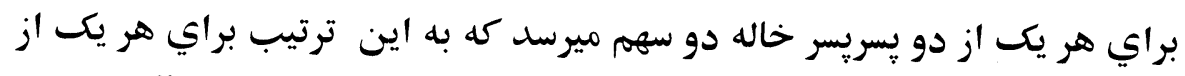

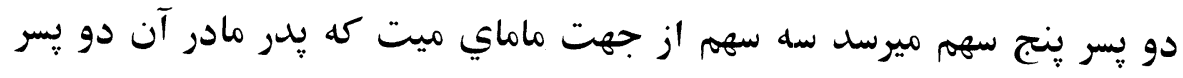

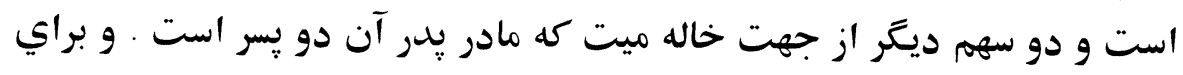

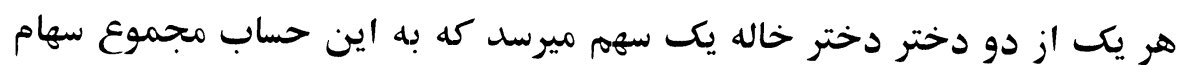

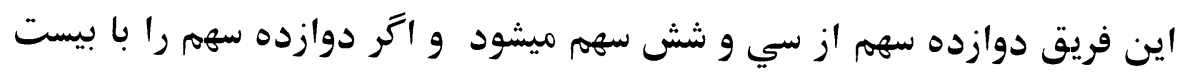

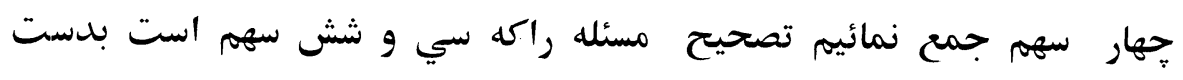
ميدهد.

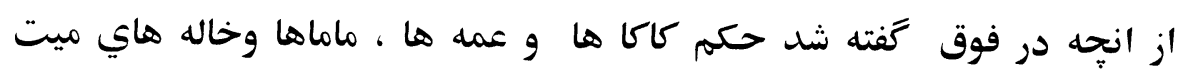

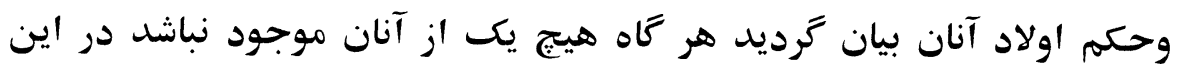

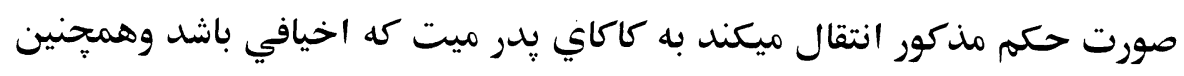

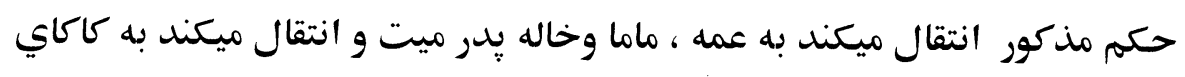

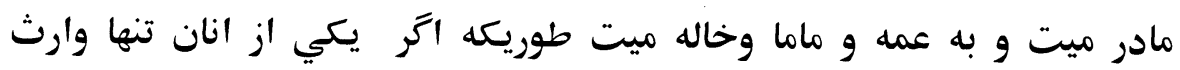

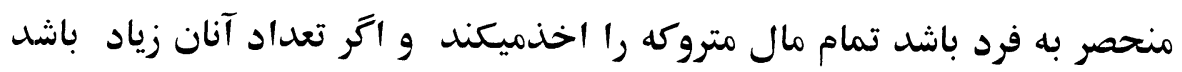

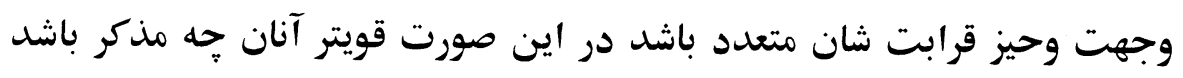

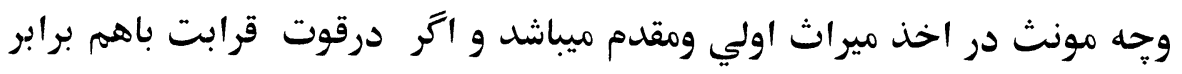

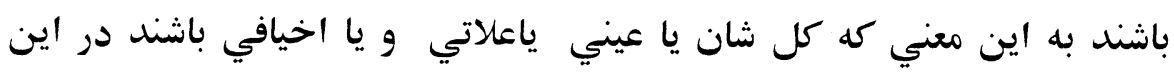

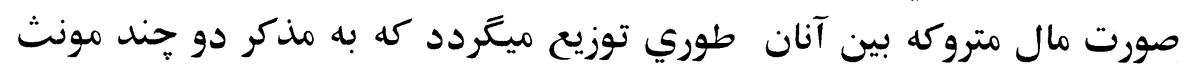

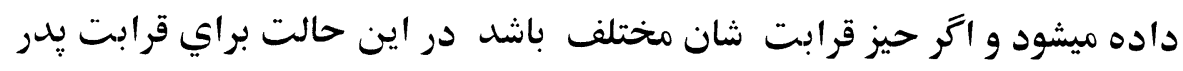

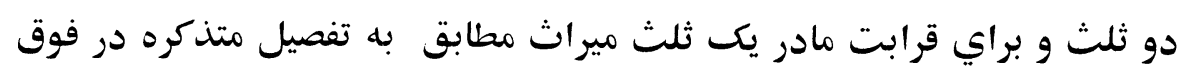

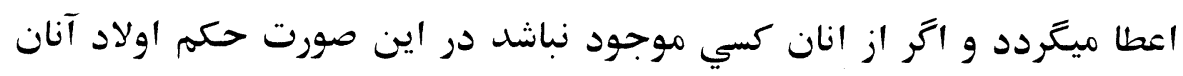


مثل حكم اولاد صنف جهارم است وا گر اولاد شان نيز موجود نباشد در اين

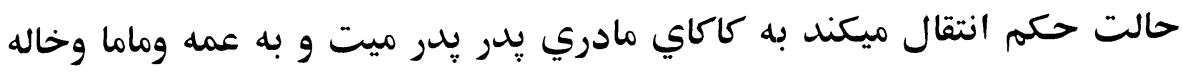

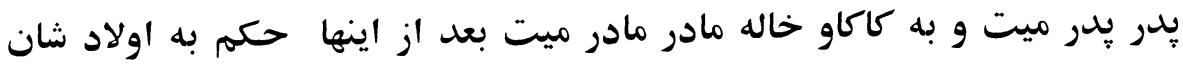

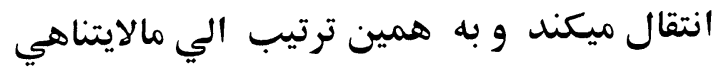


استاد عبداباري غيرت

\section{دقضاء يه ورجاندي \\ دافغان مهاجر ينو ستو نزي}

دوه يمه برخه

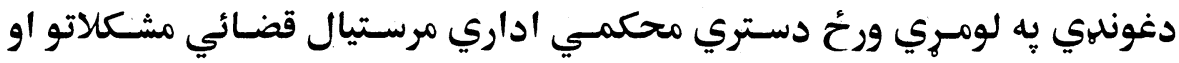

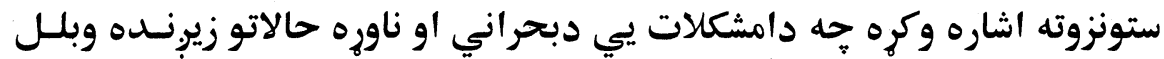

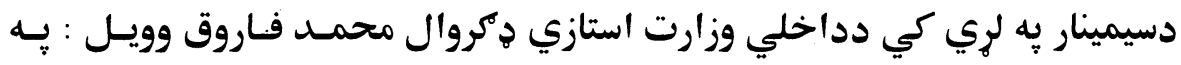

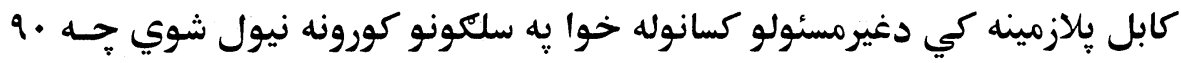

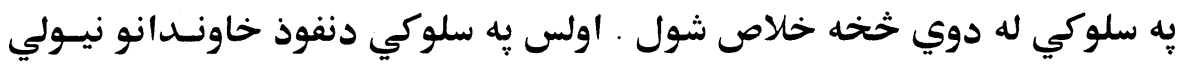

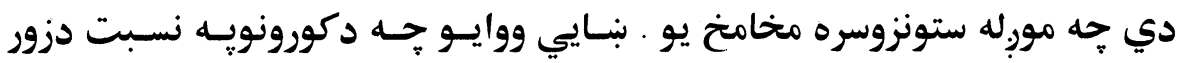

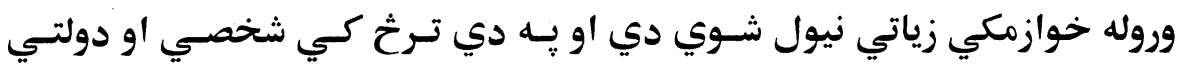

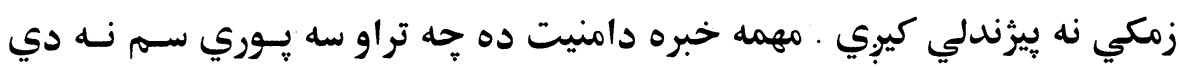

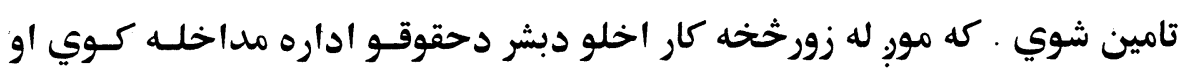

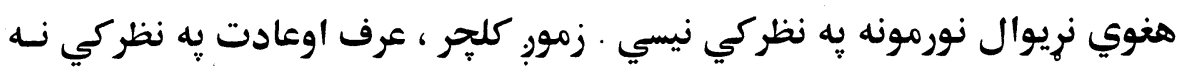

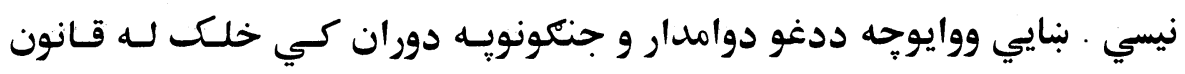

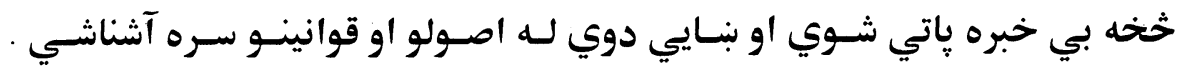

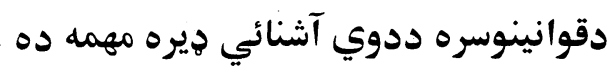

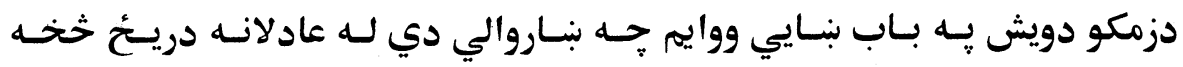

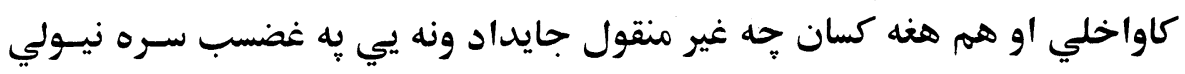

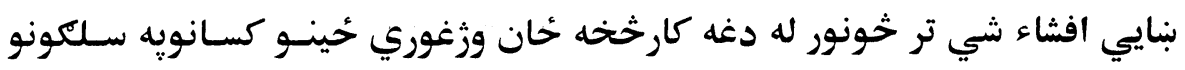

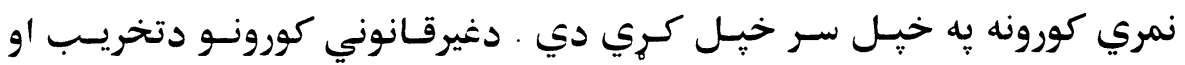




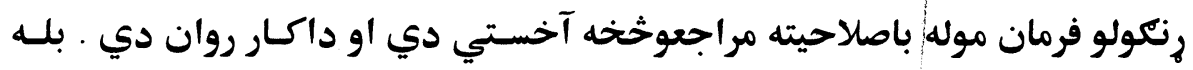

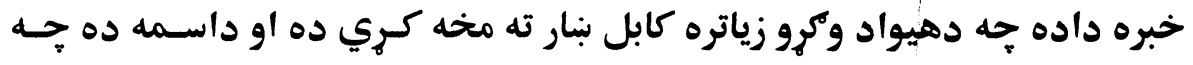

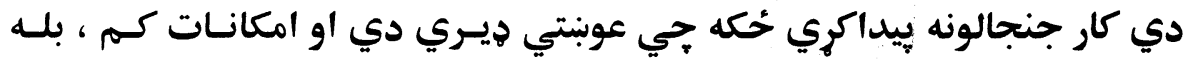

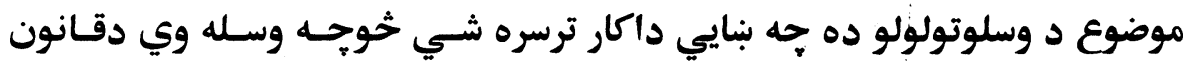

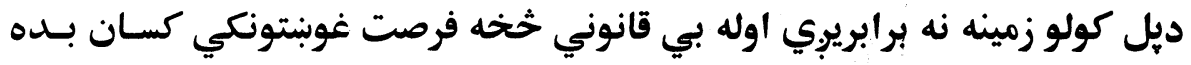

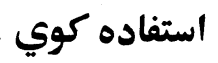

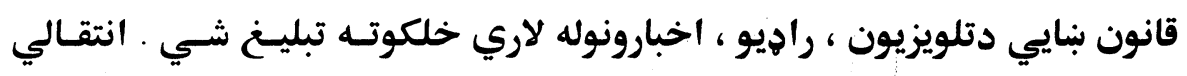

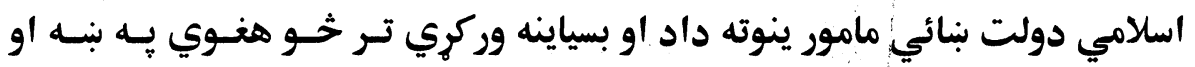

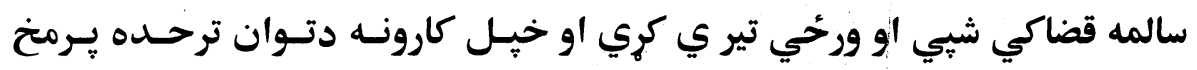

بوزي

له ده وروسته دمهاجرينود وزارت معين خيله بيانه واورولـه جـهـ عمــده تكسي ئسي دادي : ليكر

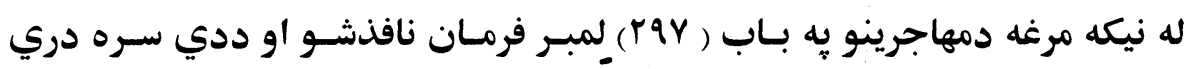
مليونو مهاجرو هيواد ته درانك بلنه ومنله .

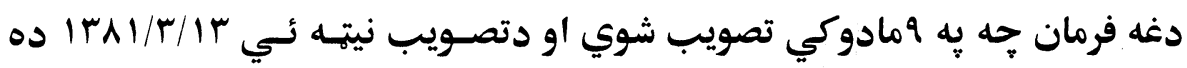

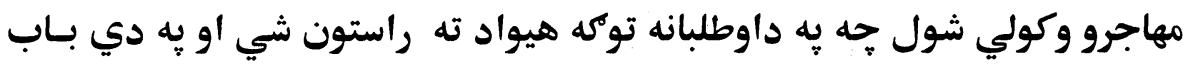

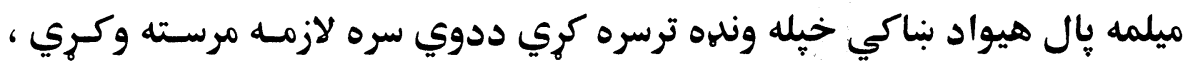

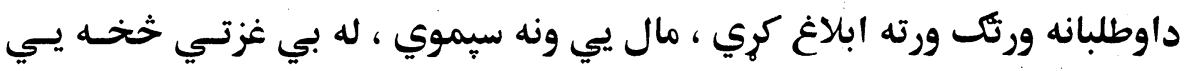

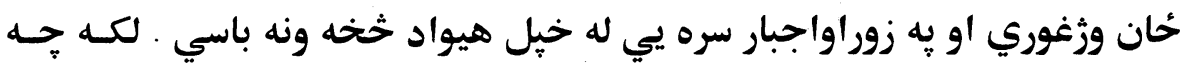

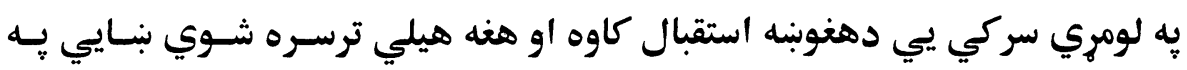

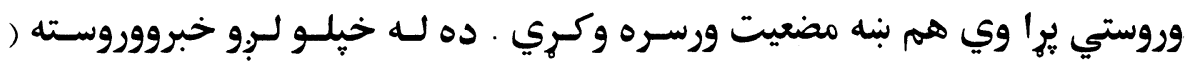

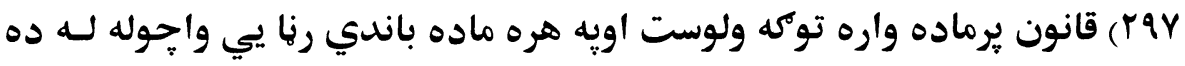

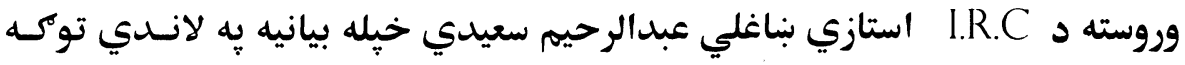

$\Delta \cdot 0$ 
واوروله : دمهاجرينو سر هرارخيزه همكاري بنـايي وشسي . ددوي دلاسه وتلونـه .

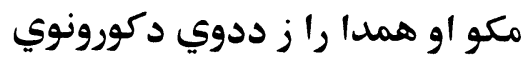

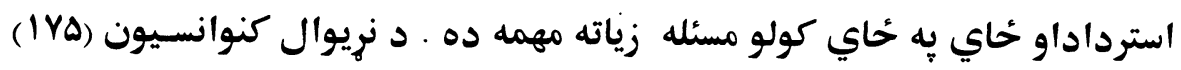

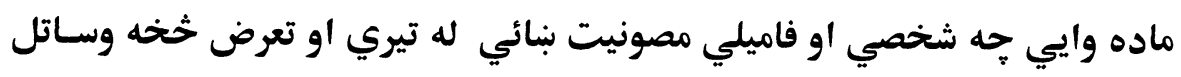

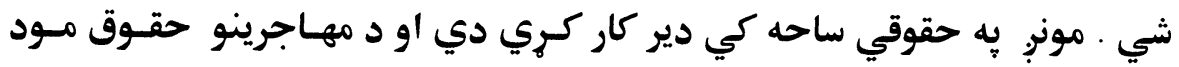

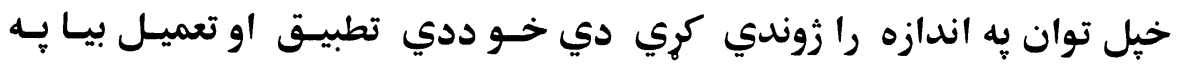

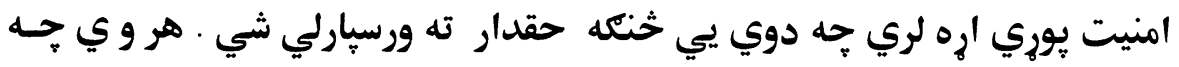

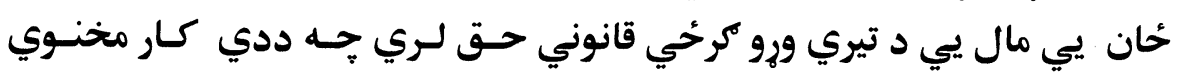

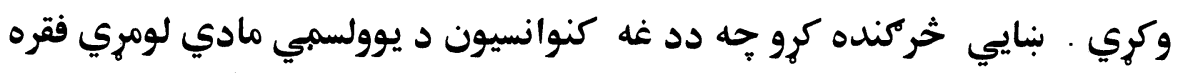

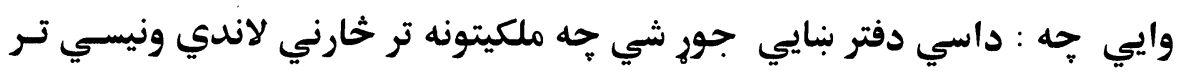

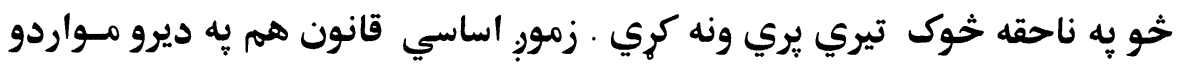

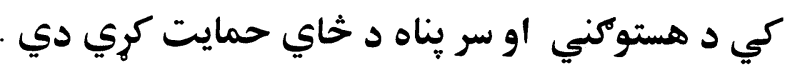

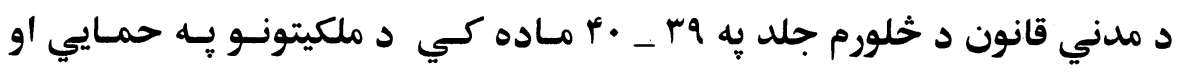

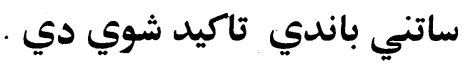

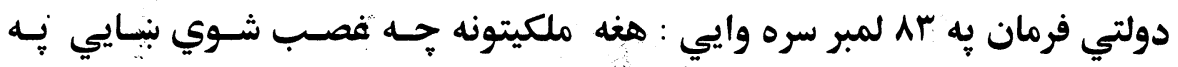

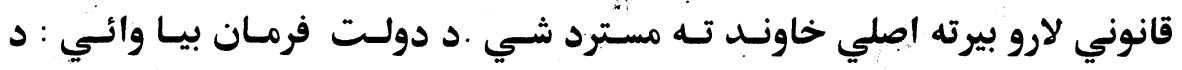

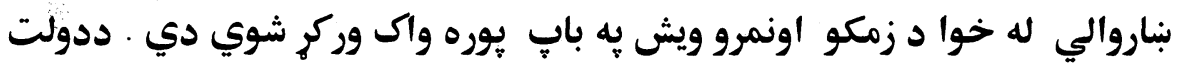

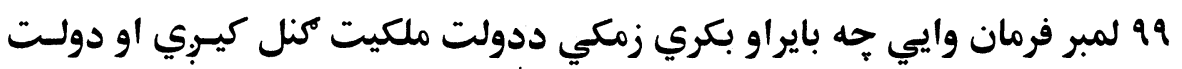

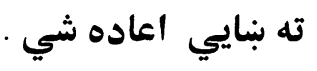

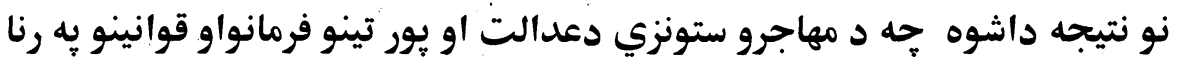

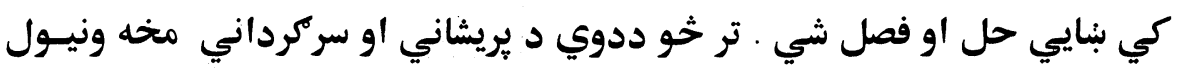

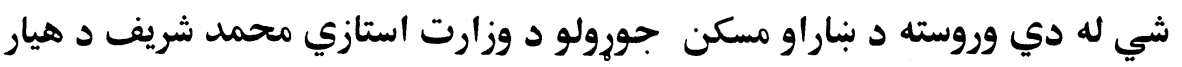

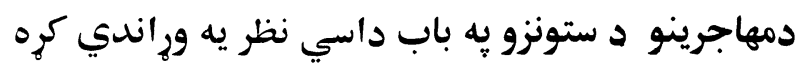




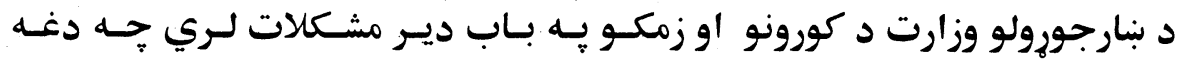

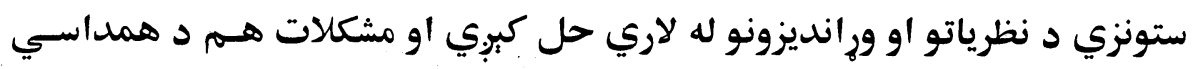

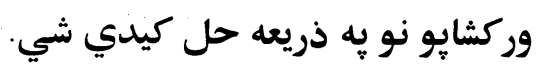

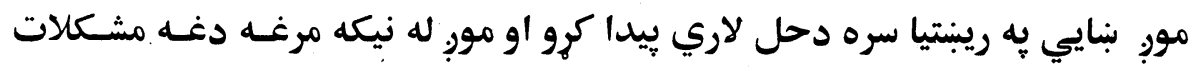

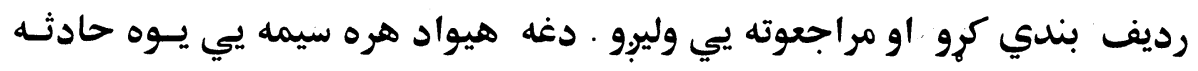

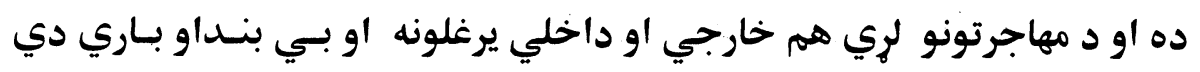

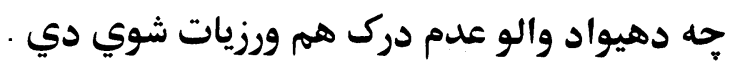

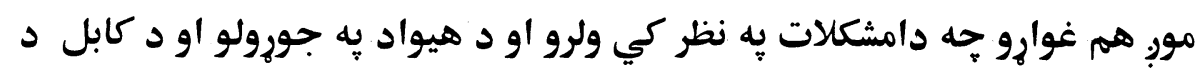

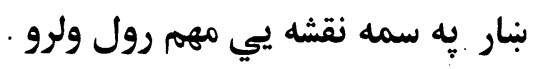

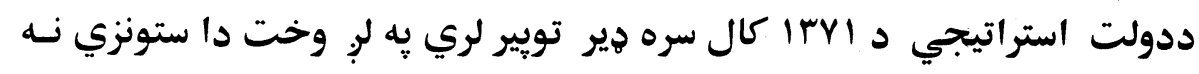

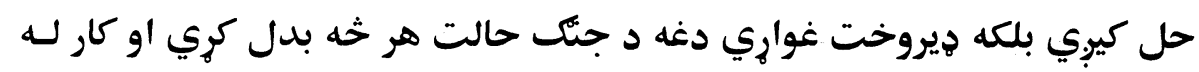

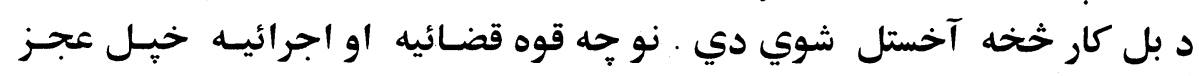

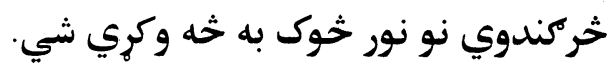

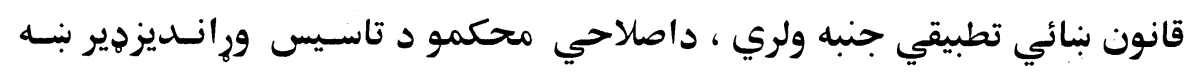

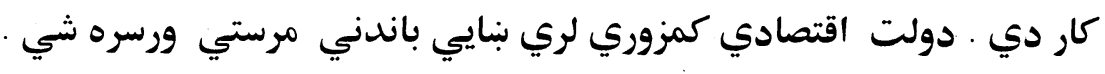

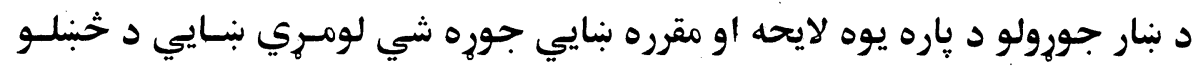

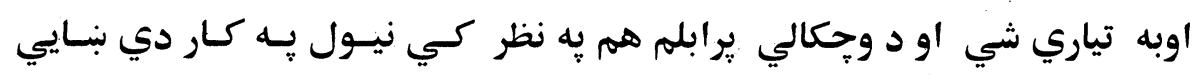

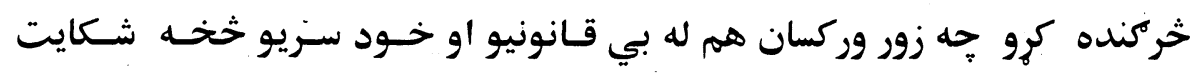

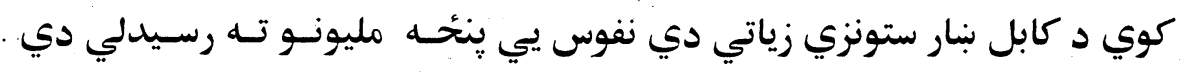

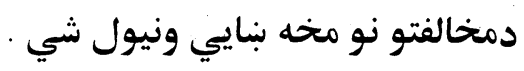

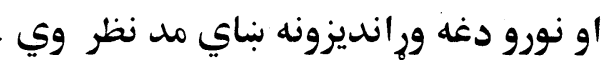

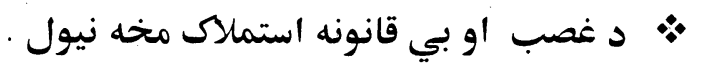

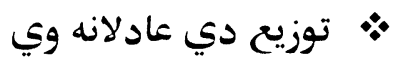
• اداري دي منظمي كار وكري 
عصري وسائل دي يِ كار شي

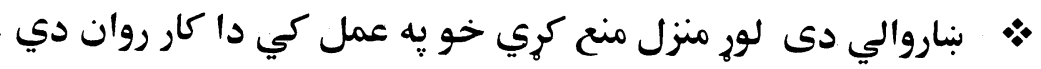

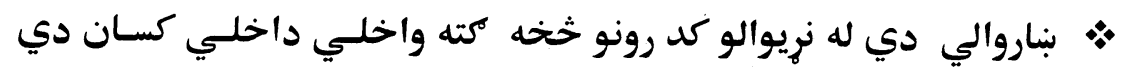

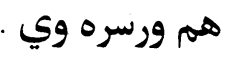

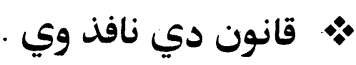
•يو مهاجرو له يوي كورني سره تللي خو له ينحُو كورنيو سره راغلي دي .

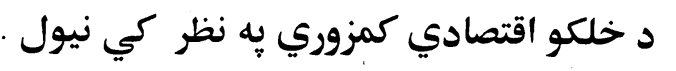

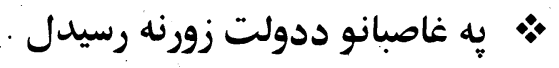

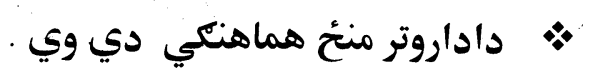

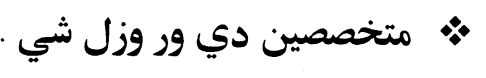

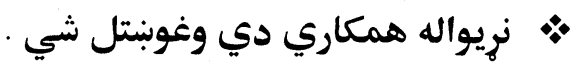

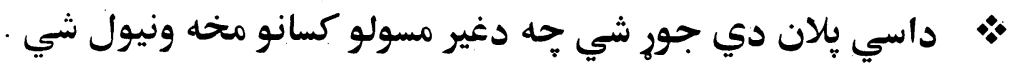
د قوانينو مراقبت دي وشي دوني له ده وروسته بيا د بناروالي ( استازي علي حسن دوني داسي دوي وويل:

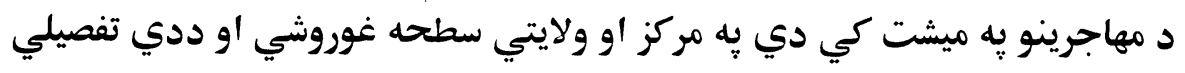

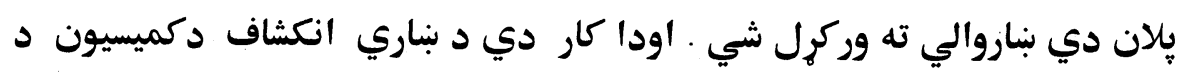

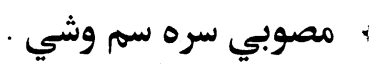

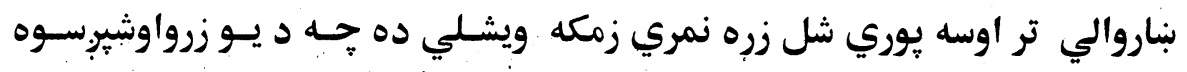

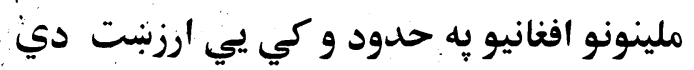

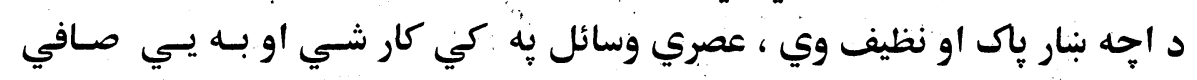

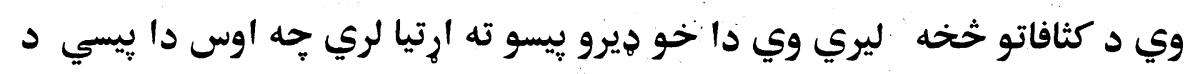

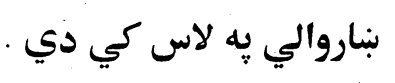

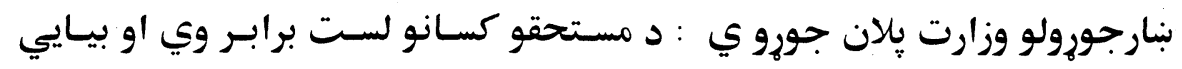

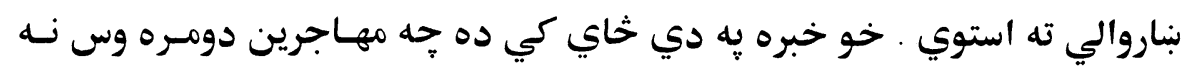

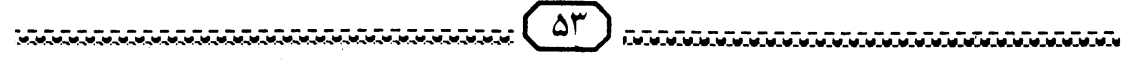


لري جه زمكه واخلي او بيايي جوره كري هغوي يه دير ناوره حالت كي راغلهي

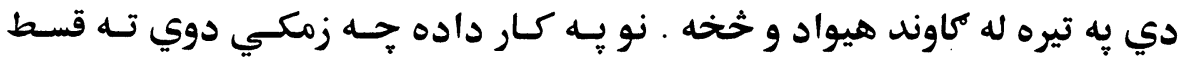

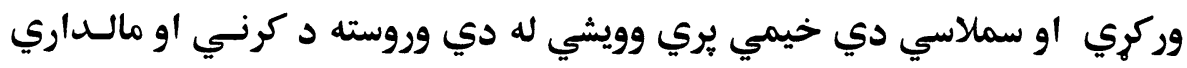

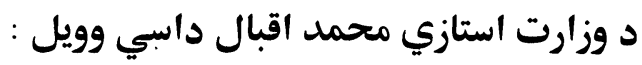

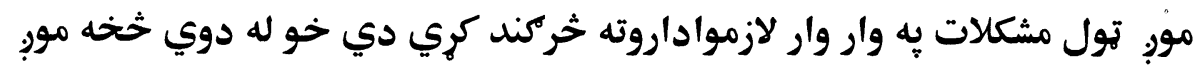

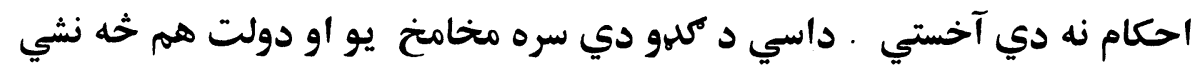

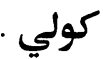

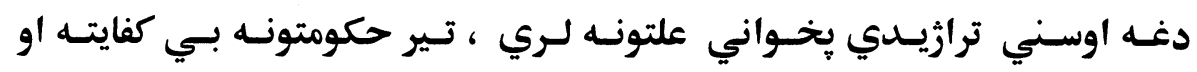

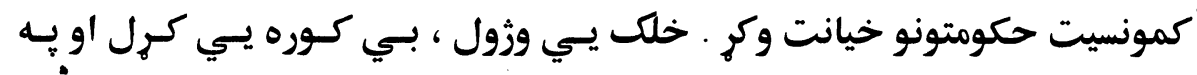

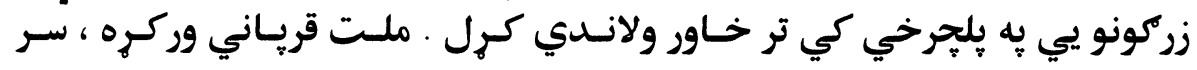

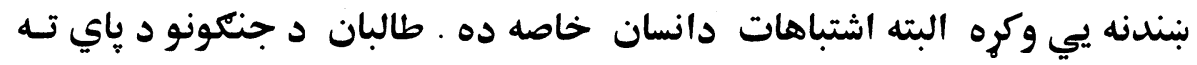

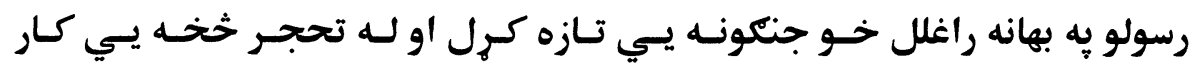

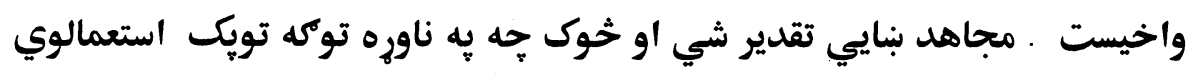

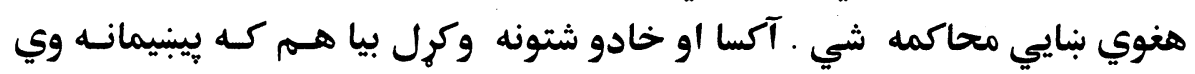

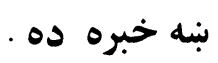

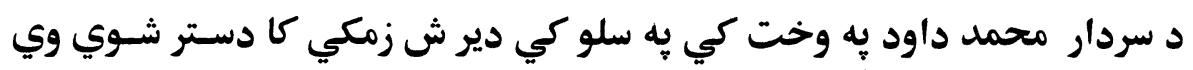

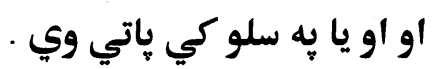

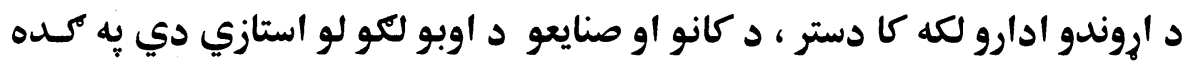

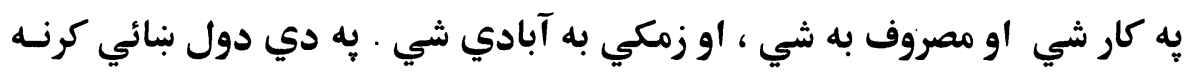

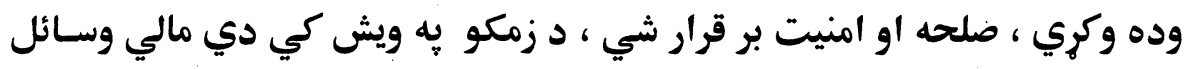

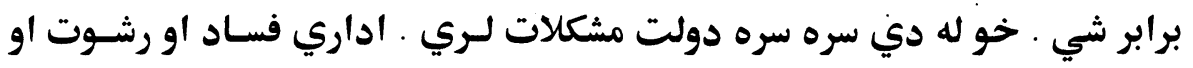

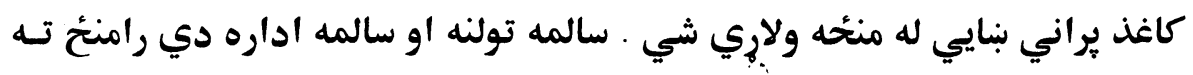
شي . وروسته دمها جرينو دوزارت د بيا ميشتولو رئيس رسولي داسي وويل : 


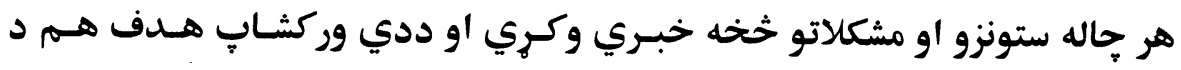

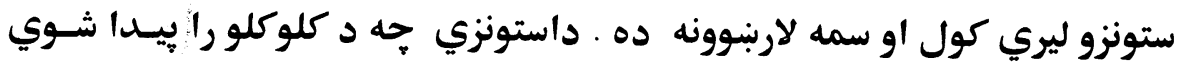

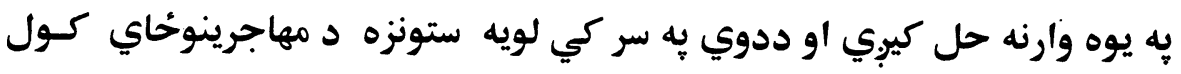

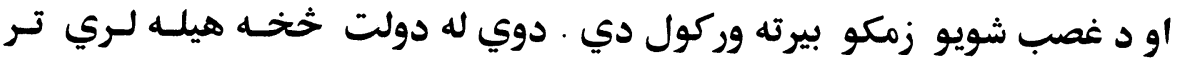

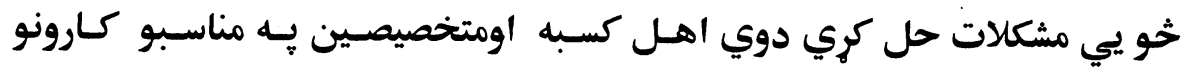

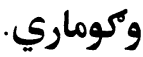

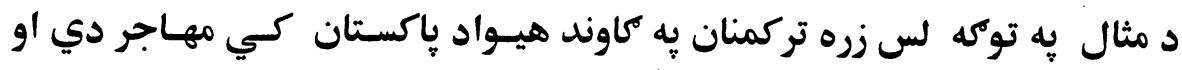

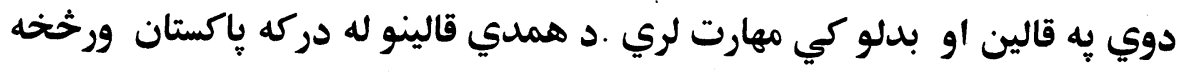

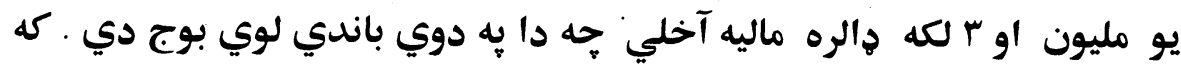

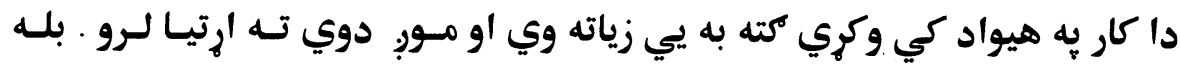

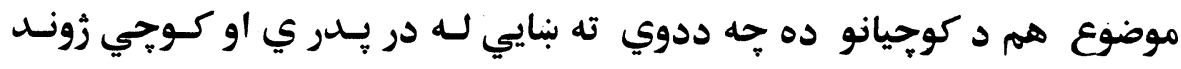

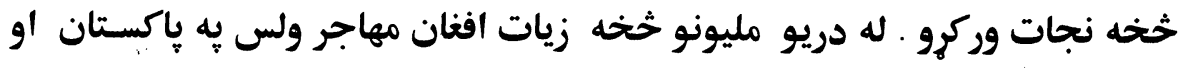

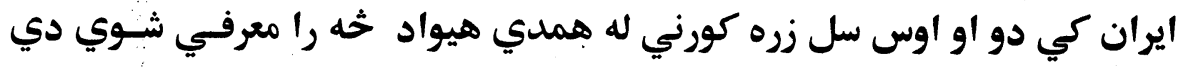

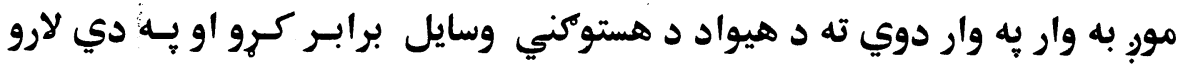

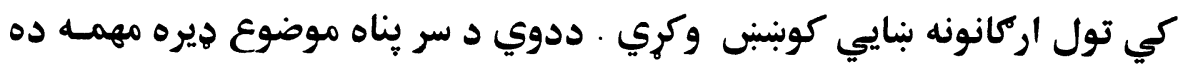

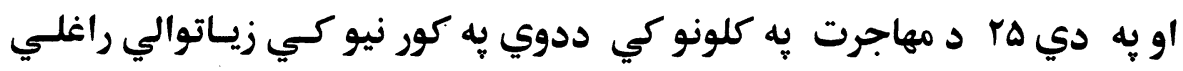
دي

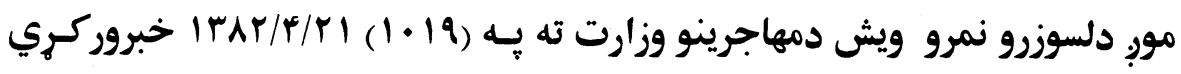

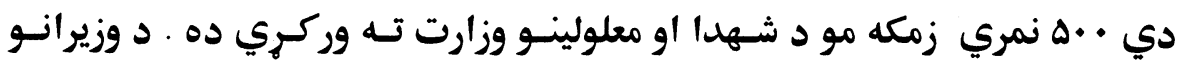

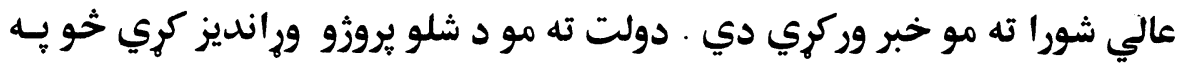

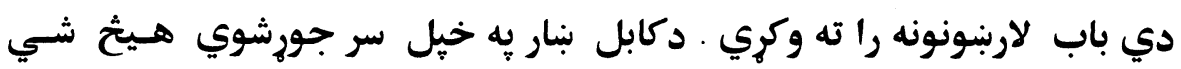

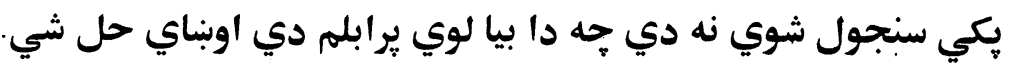

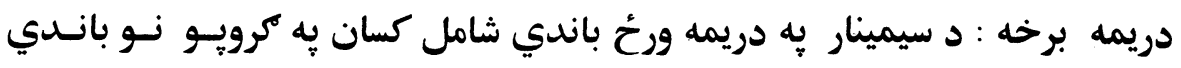

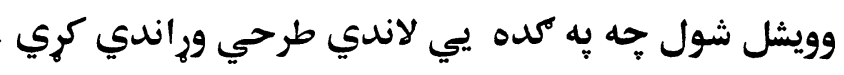




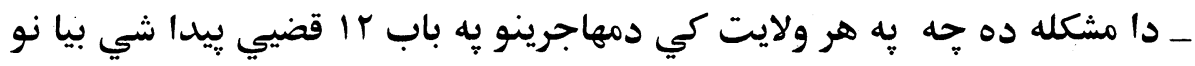

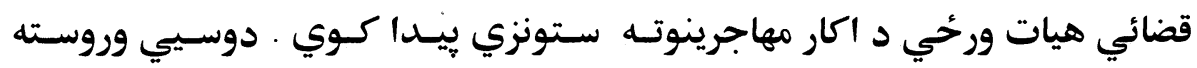
لويري

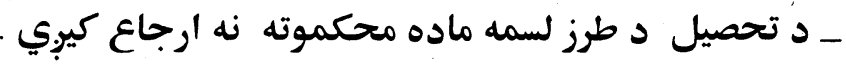

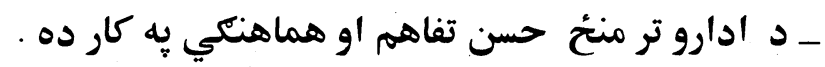
_ ـ ب بانفوذه خلكو خخه شكوه

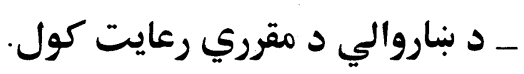

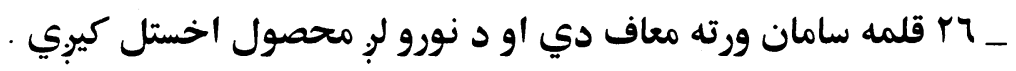

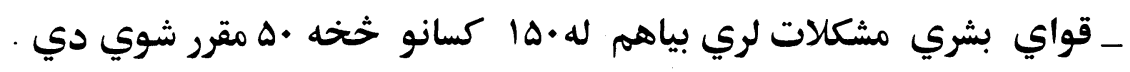

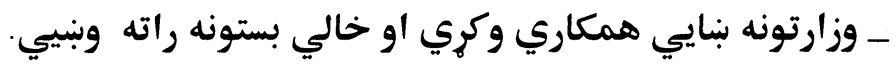

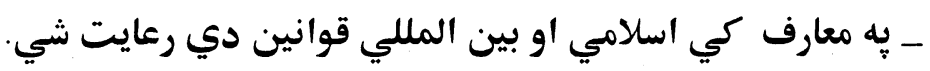

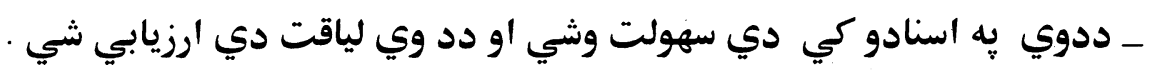

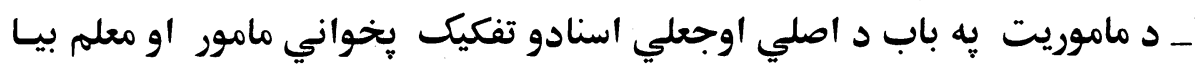
دا ستونزه نه لري .

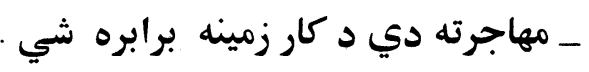

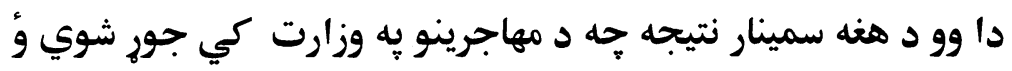
پاي 


\section{تعليماتنامه تحرير وثايق

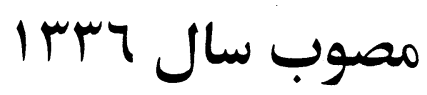

در مورد تنظيم امور وثايق اسناد تقنينسي زيادي وجود داردكه در امور روز موه

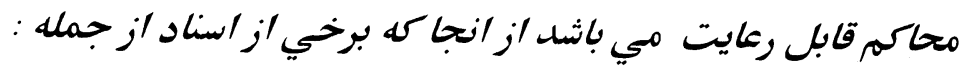

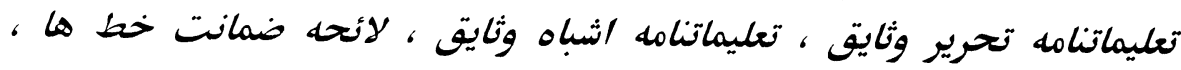

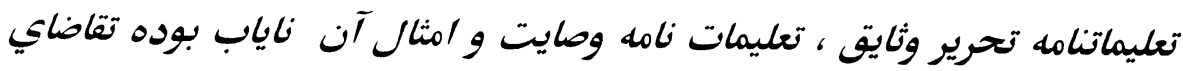
محاكم و مراجع موبوطه از يكسو و تقاضاي رياست تلدقيق و مطالعات ستره

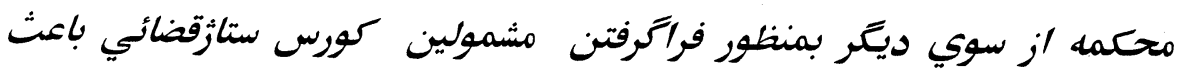

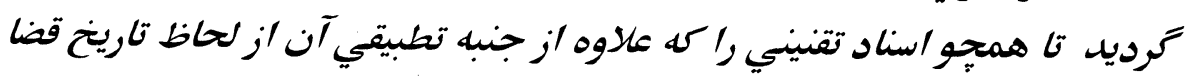

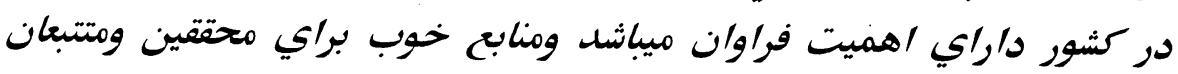

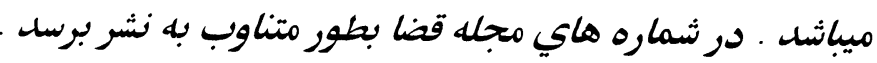

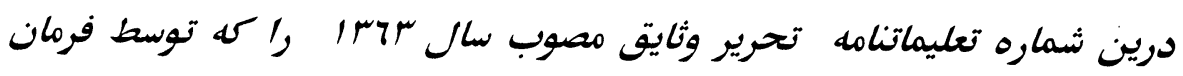

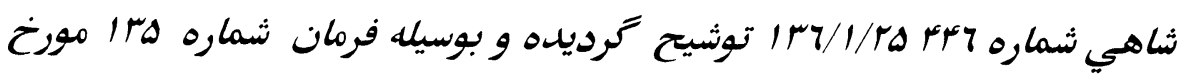

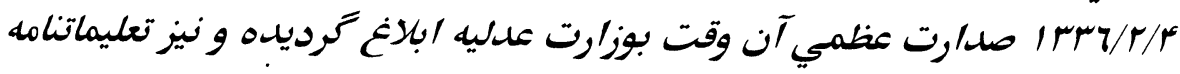

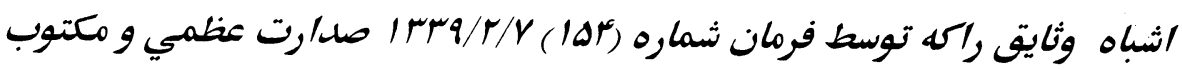

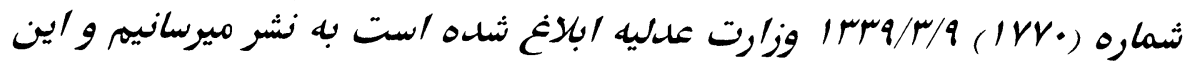

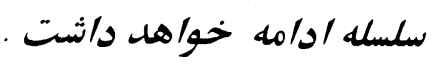
ماده اول : ماده هر كس ميتواند ازادانه به محكمه مربوط مراجعه و بعد از احضار تكت وثيقه اقرار خود را ذريعه محكمه داخل وثيقه نمائيد

ماده دوم : n 
كسانيكه بحضور محكمه اقرار مينمايند وثيقه مرتبه را بعد از طي مراتب إنب اصولي

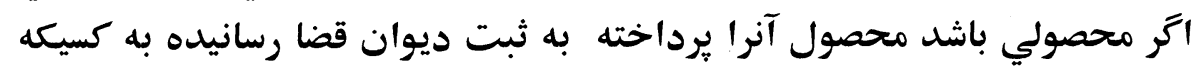

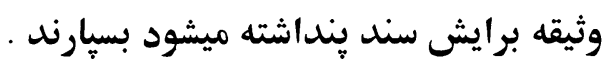

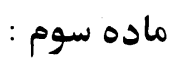

1. مصارف محكمه از قبيل قيمت ومحصول صدانه بر ذمه كسي خواهد

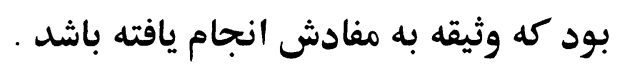

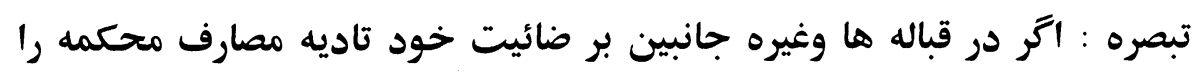

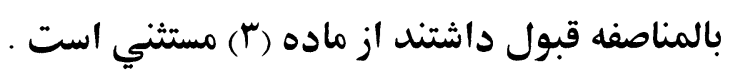

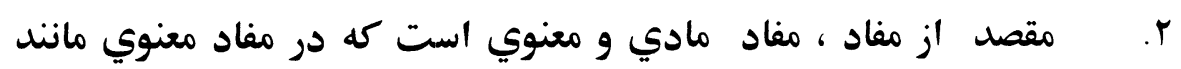

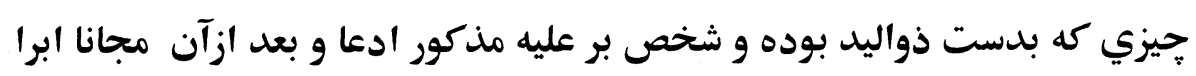

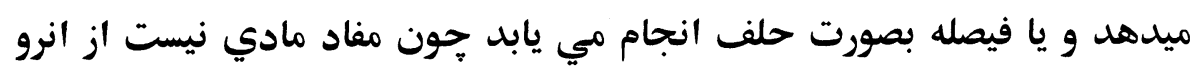

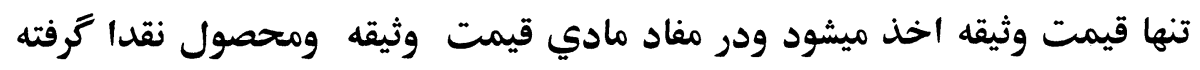

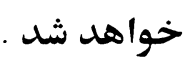
r. اضر در دعاوي وارده ادعاي ناحق و باطل شخص ادعا كنتد بحضور

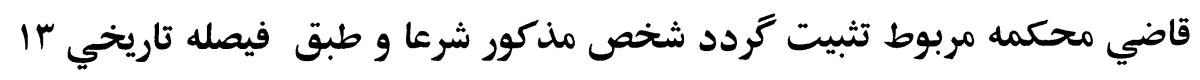

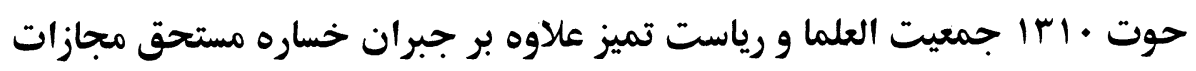

$$
\begin{aligned}
& \text { تعزيري است . } \\
& \text { ماده جهارم : تعزي }
\end{aligned}
$$

اكر جانب مقابل هم سواد نقل وثيقه را خواهش مينمود تنها قيمت وثيقه راتاديه

$$
\text { ماده نينجم : مايد وبس : }
$$

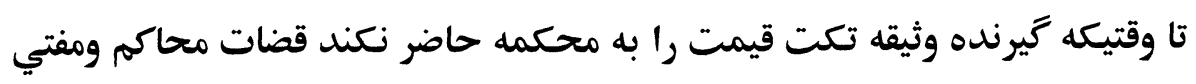

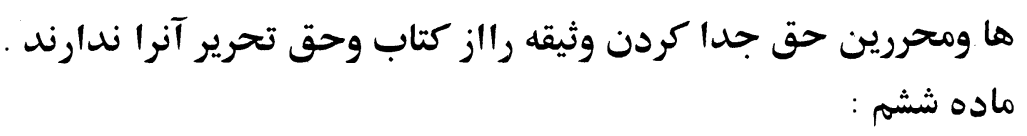


تكت محصول صدانه وثايق بعد از طي مراتب اصولي در وقت اقرار مقر و ثبت

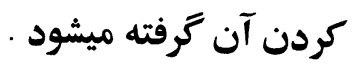
ماده هفتم :

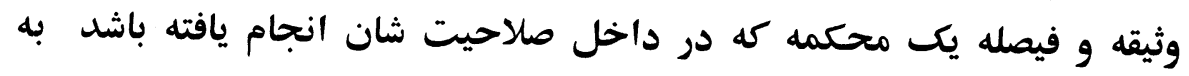

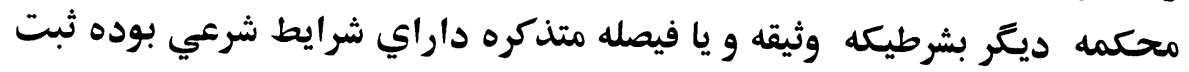

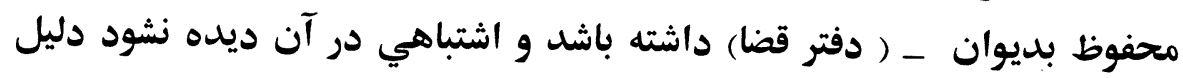
حكم و اعتماد شده ميتواند . مدان. ماده هشتم :

وثيقه و فيصله كه داراي ثبت محفوظ قضا باشد وخالي از تحريف وعاري از

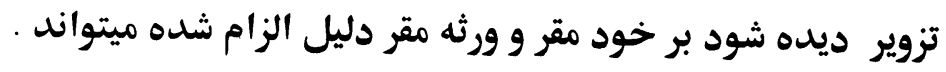

ماده نهم : تروير

تطبيق وثيقه يا فيصله با مندرجات آن و اينكه ثبت محفوظ دارد يا ندارد و مدار

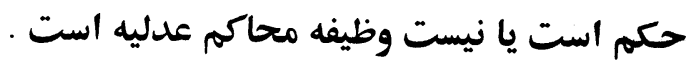
ماده دهم :

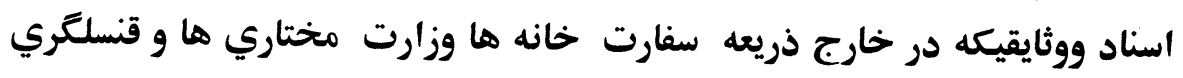

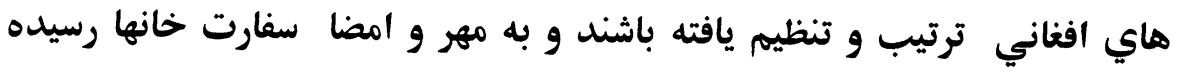

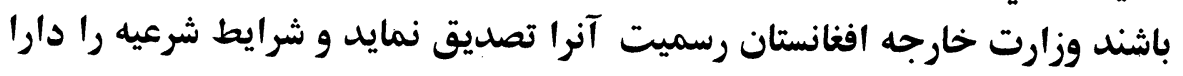

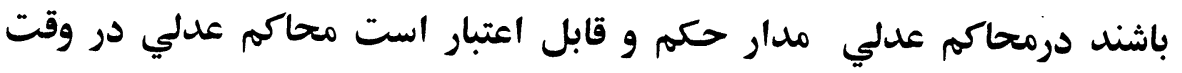

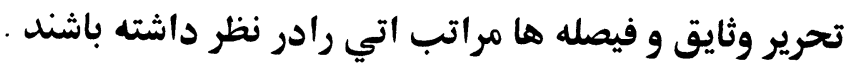
ماده يازدهم :

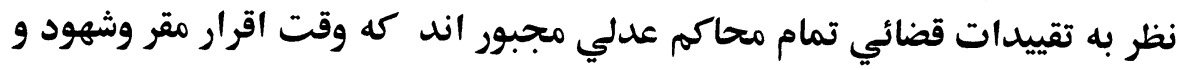

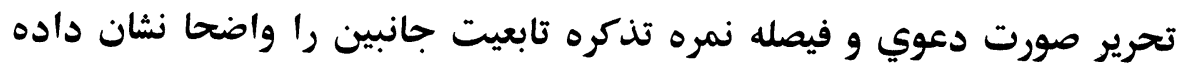

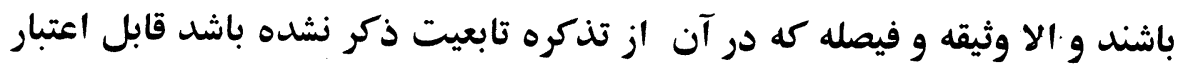


ماده دوازدهم : در منطقه ايكه عكس مقر و مقر لله مدعي و مدعي عليه و شهود بدست آمده

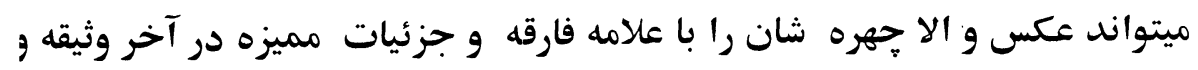
فيصله تحرير نمايد.

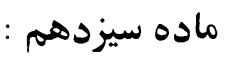
قضات و مفتي هاو محررين محاكم عدلي مكلف هستند كه در تصحيح املا و رسه الخط دقت نمايند ماده حهاردهم : نظر باينكه تغير حروف وكلمات موجب تغيير معاني است محكممه بالاتر ميتواند

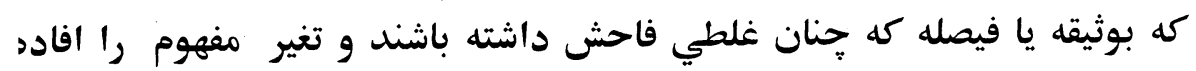

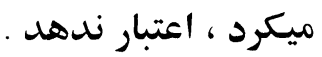

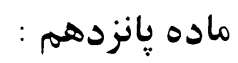

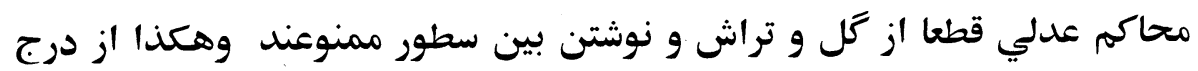

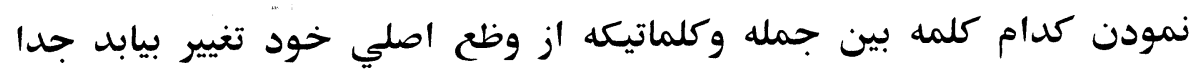
احتراز نمايند ماده شانزدهم :

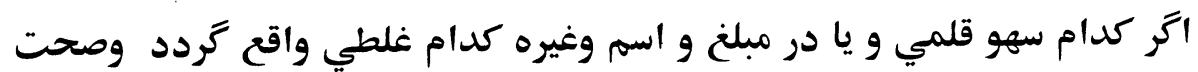
آنرا ضرورت شرعي ديده باشد بعد از اتمام هر نوع و ثيقه يا فيصله در اخره اخران

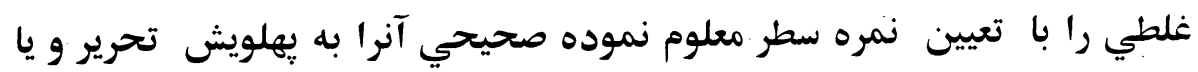

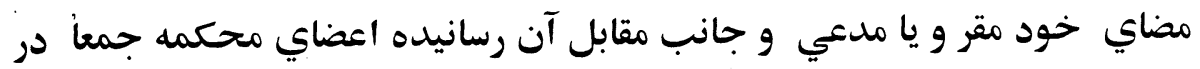
اصل و نقل آن امضا نمايند. تبصره : اتر جانبين امضا نداشتند بِّسِانيدن شصت شان اكتفا و دو نفر مصدق نيز امضا مينمايند . 
ماده هفدهم :

اتر وثيقه در موقع حدود وغيره كمبودي نمود بايد در ظهر وثيقه تحرير شود

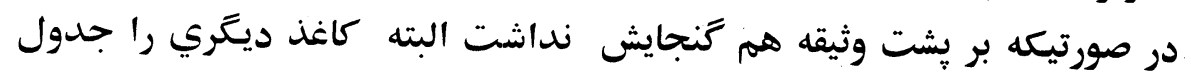

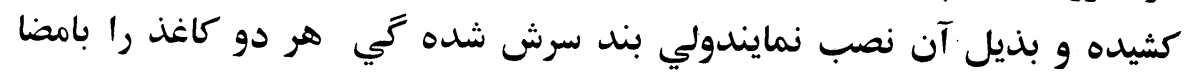
ومهر اعضاي محكمه برسانتد . ماده هزدهم: وثايقيكه بغرض ملاحظه بعضي دواير رسمي و يا ومهيل هاي تخذر و غيره معطلي

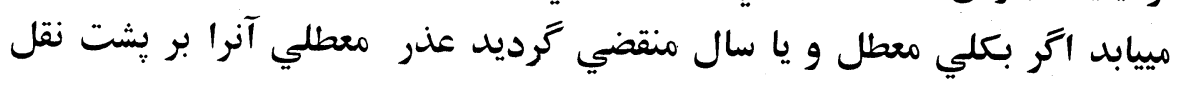

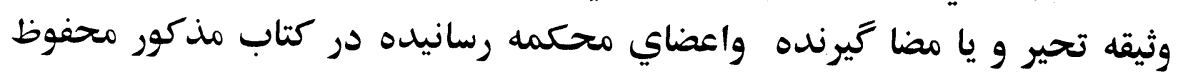

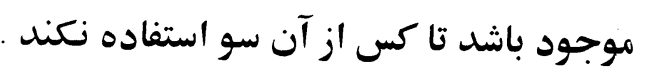
ماده نزدهم : موحد باتش

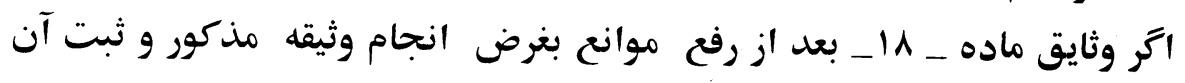

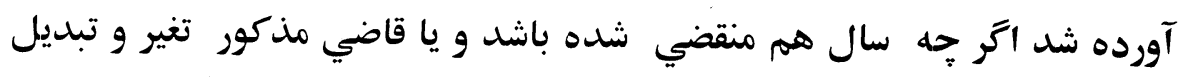

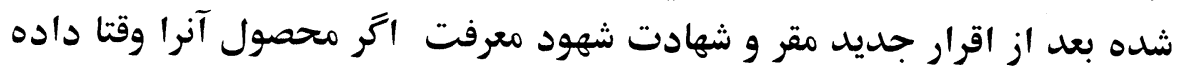

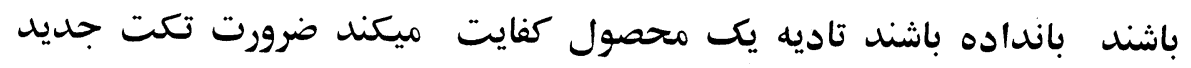

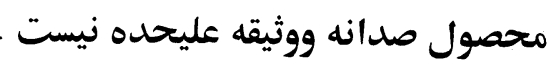
ماده بيستم : ماحصو

اتر شهود مثبته بعد از دعوي مدعي و جواب مدعي عليه در ضورت دعوي موجود بود و شهادت شان تحرير شده باشد در صورتكيه در اثنا قاضي از وظيفه

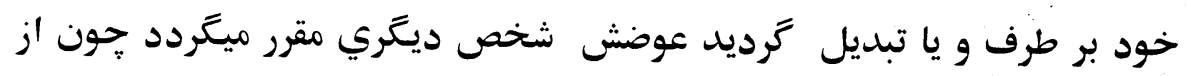

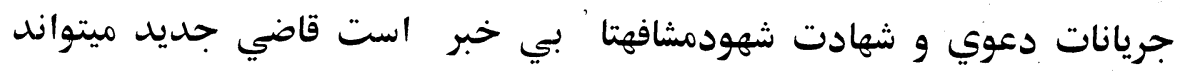

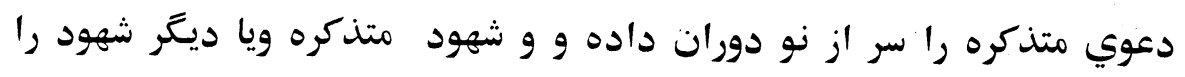
مطالبه واستماع نمايد و به دعوي وجواب دعوي و شهادت شهود مندر دورجه صورت دورت

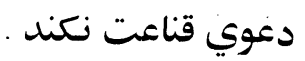




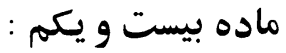

محاكم عدليه مجبور اند در هر دعوي عقود وغيره اتر بصورت فيصله صادر ميشود و يا طور اقرار مقر انجام مييابد همان شرايط شرعي كه در درع عقد وغيره ويا

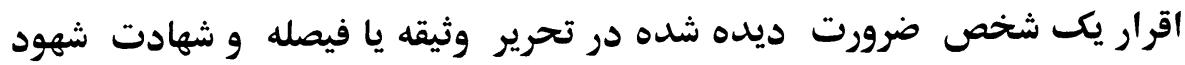

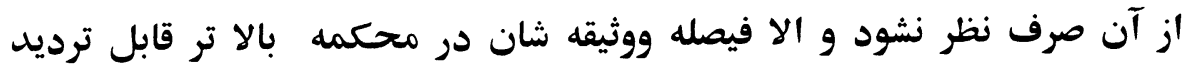

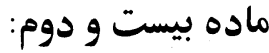

محاكم عدليه مجبور اند دلائل مدعي ومدعي عليه يا شهادت شهود را آر آر ترديد مينمايد هر كدام آنرا جدا جدا با دلايل ترديد نمايند. ماده بيست و سوم : ماديب محاكم عدليه مجبور اند كه در تحرير وثايق و فيصله ها در موضوع دعوي مدعي و جواب مدعي عليه و شهادت شهود وحكم مرتبه قضا الفاظ مجمل و بي

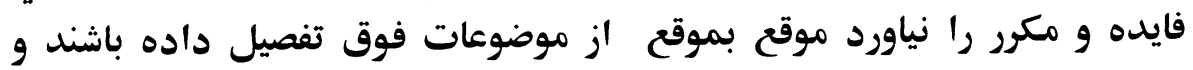
دولايل جانبين و شهادت شهود را بي كم وكاست واضحاً تحرير نمايند. ماده بيست و :جهارم : محاكم عدليه مجبور اند حكم راكه صادر ميكنند علل و اسباب حكم را با جزئيه

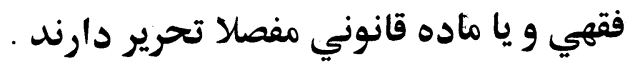

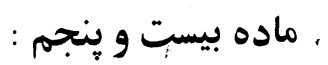

محاكم عدليه نظر به تقييدات قضائي مجبور اند كه در فيصله خود ذكر نمايند : بعد از فتواي مفتي حكم نمودم از انرو وثيقه يا فيصله را اولتر بايد مفتي مهر نموده و سيس آنرا قاضي مهر نمايد .

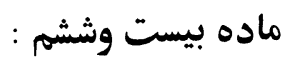
قاضي ها نميتوانند در وقت حضور مفتي هاوثيقه يا فيصله را تنها به مهر خود از محكمه صادر نمايند در صورتيكه مفتي حضور نداشت عذر معقول بآنرا. اصولا به ميه 
يُشناني وثيقه تحرير خواهند نمود والا وثيقه يا فيصله متذكره بحضور محاكم بالاتر قابل ترديد است. ماده بيست وهفتم :

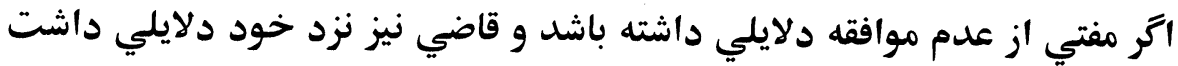

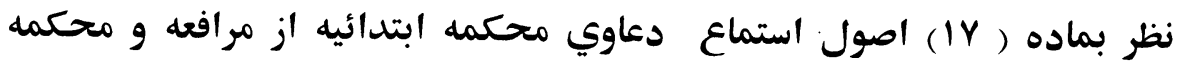
مرافعه از تميز استهدا خواهند نمود.

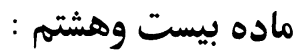

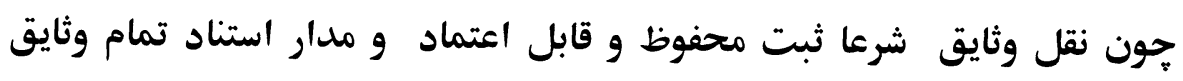

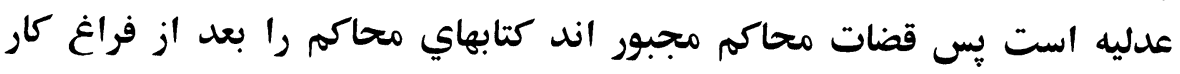

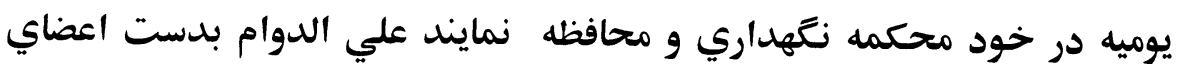

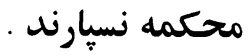

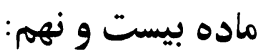

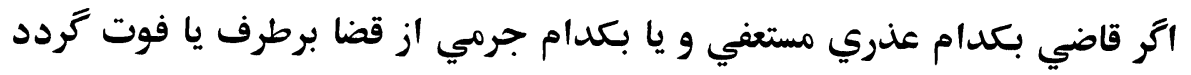

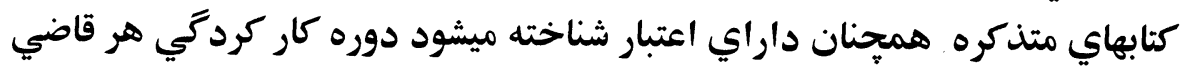
از ختم ماموريت او ذريعه يك هيئت دركتاب قيد و نشاني ميشود. ماده سي ام : أنماموريت

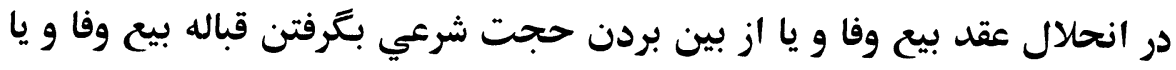

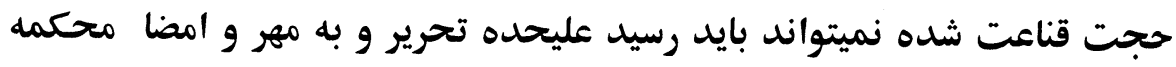

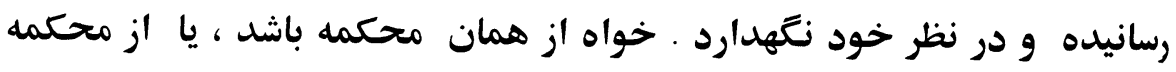
ريتر . رنانيل

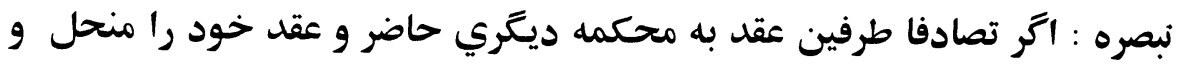

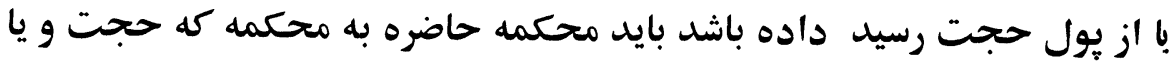
فباله بيع وفا را نوشته است خبر بدهد . ماده سي و يكم : 


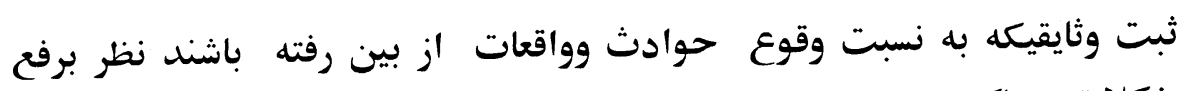

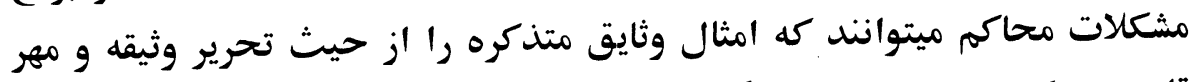

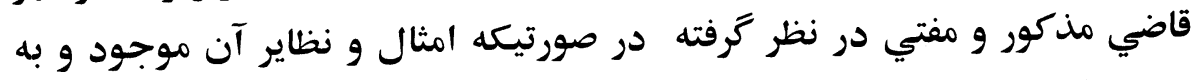

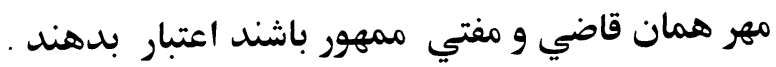

$$
\text { ماده سي دوم : مان مان }
$$

محاكم عدليه نميتوانند به كس وثيقه سفيد را داده و او به محكمه ديگري برده

$$
\text { و تحرير نمايد . }
$$

تجاويز شرعي بيع و شرا اموال و املكى كه از جانب صنار و و يا براي صغار

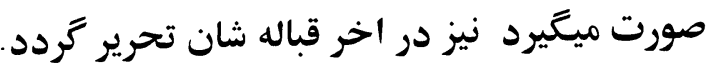

$$
\begin{aligned}
& \text { ماده سي و حهارم: }
\end{aligned}
$$

در وصايت و نفقه صغار اموال منقوله حصه صغار جز وار تحت تحرير آورده شود و در آخر آن امضاي وصي و اعضاي محاكم نسبت به تسليمي آن ضروريست

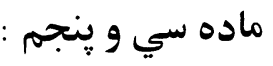
ابراي يك دعوي در حاليكه در كدام محكمه داخل صورت حال شده شده باشد به محكمه ديَّر صورت ترفته نميتواند.

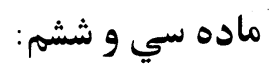

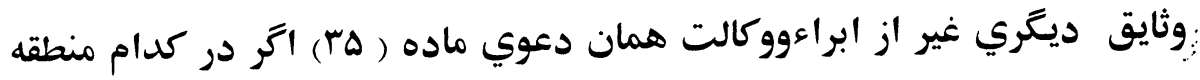

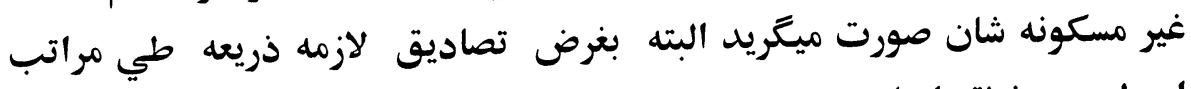
اصولي به منطقه اصلي و مسكونه شان فرستاده ميشود .

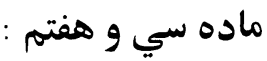

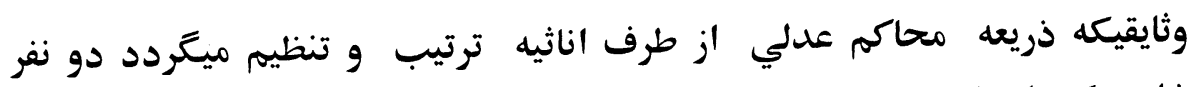
شاهديكه او را شخصا بشناسند يا يكنفر مصدق حتميست

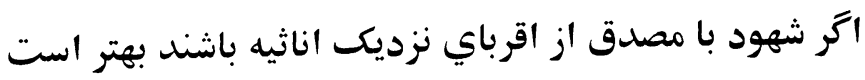




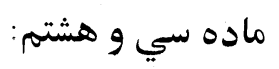

وثايق صلح و ابراء اكر مشبوه واقع شده و يكي از جانبين بران اعتراض داشت داشته

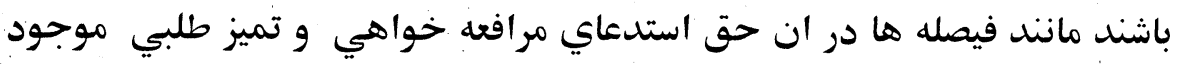

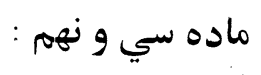

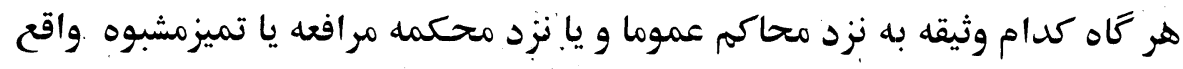

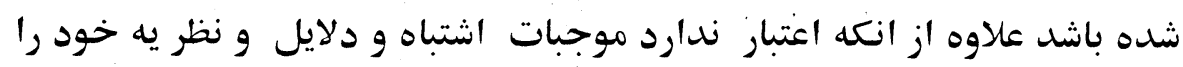

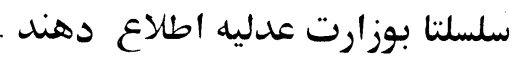

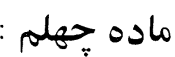
بجز مامورين ربمي محكمه اشخاص ديكري حق تحرير وثايق و فيصله هارا در محاكم ندارند. ماده جهل ويكم:

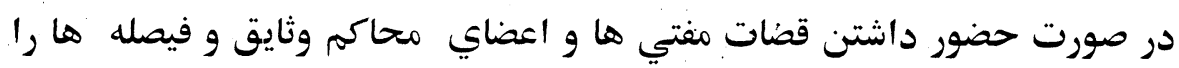

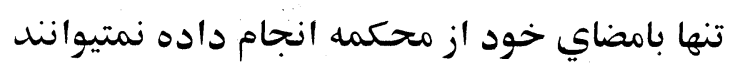
ماده جهل و دوم: ديون مثبته كه مستغرق متروكه متوفي باشد نظر باينكه تاديه دين نسبت بارث

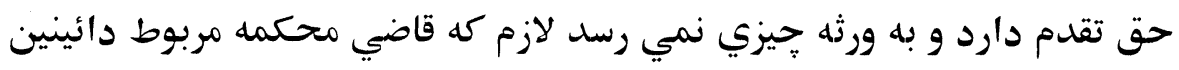

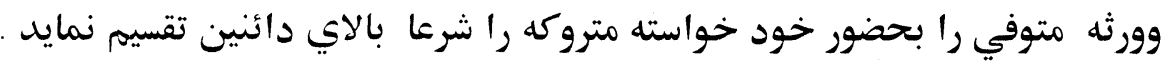

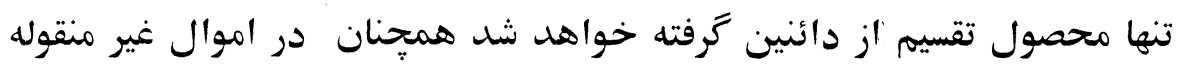

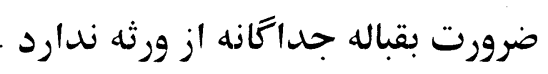




\section{تعليماتنامه اشباه وثايق \\ مصوب سال وبr 1 أش}

وثايق و فيصله هاي محاكم عدلي ذيلا مشبوه و مورد اعتراض معترض واقع شده ميتواند 1.ثبت محفوظ بديوان قضا نداشته باشد . در حاليكه كتاب ثبت همان تاريخ وجود داشته باشد r. در مندرج آن بين اصل و ثبت تفاوتي موجودباشد داسل r.در اصل و ثبت حنان سطوري نوشته باشد كه مطابق تعليماتنامه تحرير وثايق در ان اجرآتي نشده باشد بشرطيكه وثيقه بعد از وصول تعليماتنامه ترتيب شده باشد. זا.عكس و يا جهره مقرو يا شهود وملعي عليه واضحا تغيير شكل داشته باشد

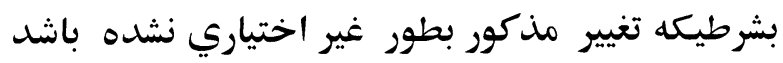

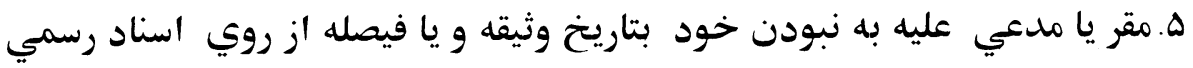

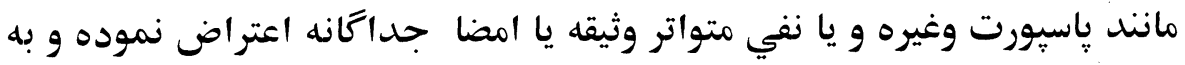
اثبات فوق رسانيده بتواند

7.قاضي و مفتي كه مهر و امضا آن در وثيقه يا فيصله باشد در تاريخ مذكور از روي دفاتر وزارت عدليه درمحاكم متذكره قاضي و يا مفتي نباشد V. بصورتيكه قاضي و يا مفتي همان منطقه تفته شود ولي قبل از از اشغال وظيفه

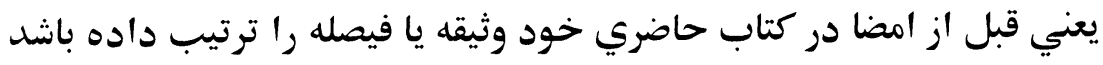
1. تفاوت فاحش سن بين تذكره و جهره در مشبوهيت تذكره و وثيقه مدار اعتبار است

9. وثيقه با فيصله و يا ثبت آن كه به خط و كتابت خود مقر لله انجام يافته باشد. 
• ا.وثيقه يا فيصله كه از استقرار و ابرا يك شخص ترتيب شده ولي ظاهر الحال

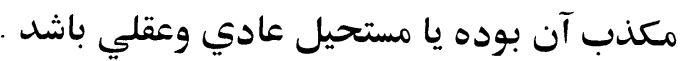

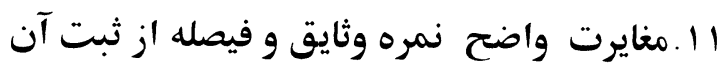

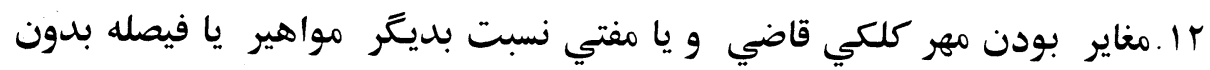

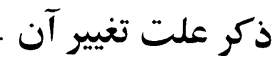

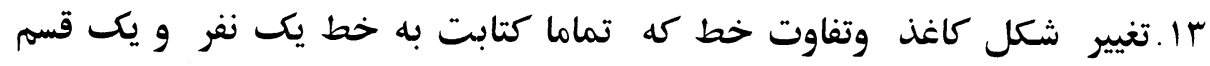

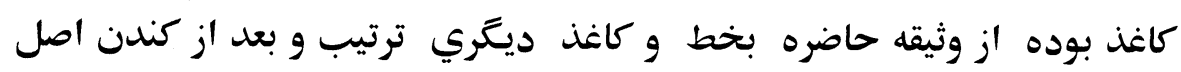

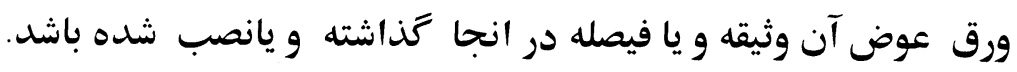

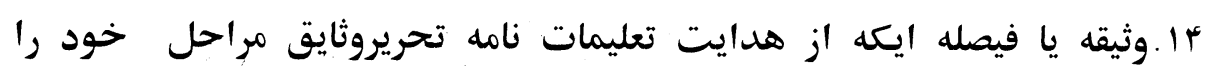

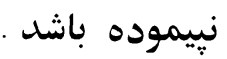
ها وثيقه يا فيصل اي كه مبني بر وصايت يا وكالت بوده ولي وكيل يا وصي خارج

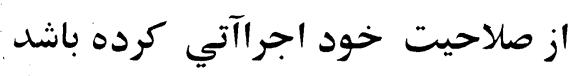

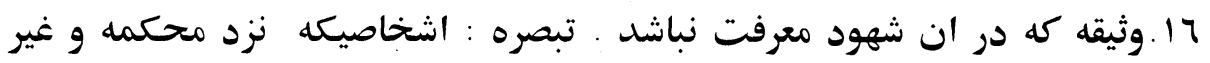

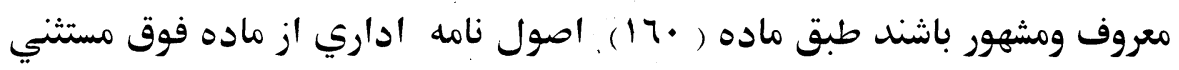
است است Y ا. وثيقه يا فيصله اي كه از اقرار اناثيه بوده و در ان حتي الامكان شهود معرفت

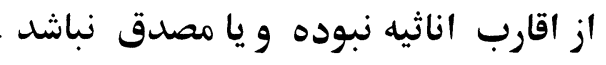

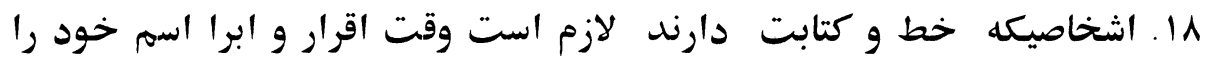

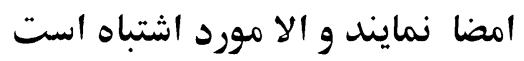

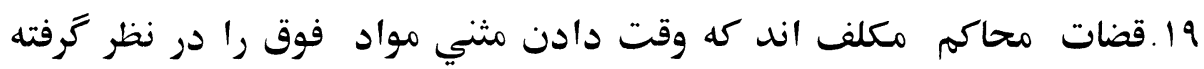

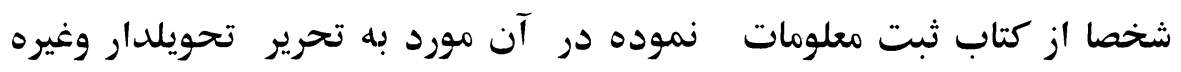

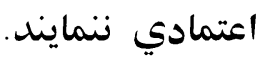

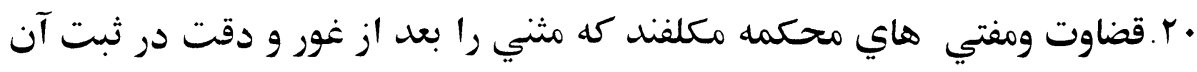

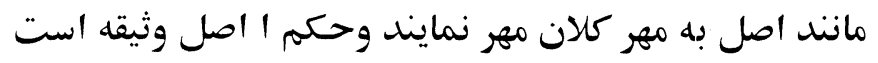


اr. مثني بايد به كسي داده شود كد اصل سند بمفاد إو انجام يافته باشد . r.r. اتر جانب مقابل ثبت كتاب را سند خود وانمود و انرا در خواست كند قاضي

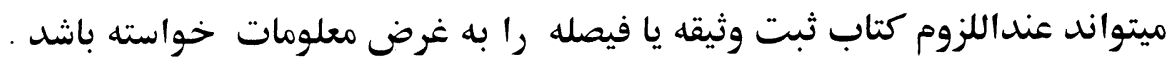

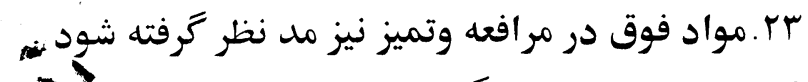

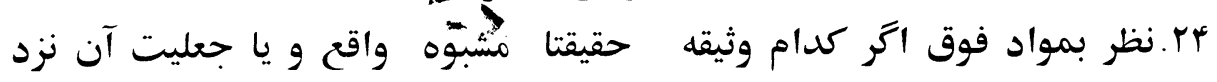

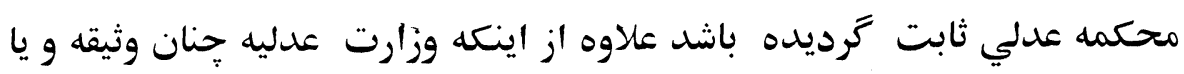

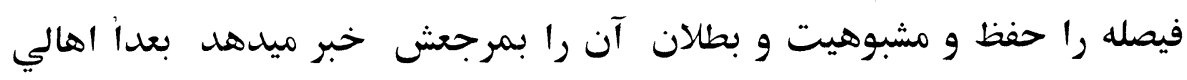

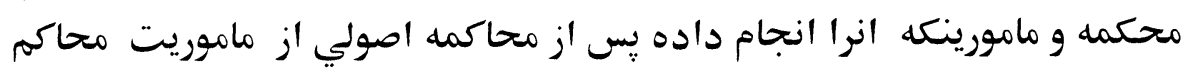

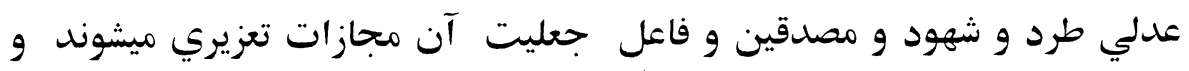
تصديق مصدقين ، اينده از اعتبار ساقط است و به اجرآت تعليت تعليماتنامه مامورين وزارت عدليه مكلف اند . 


\section{تعليماتنامه تزكيه شهود}

\section{مصوب 19 سنبله هسبا ش}

ا - اقسام تزكيه شهود :

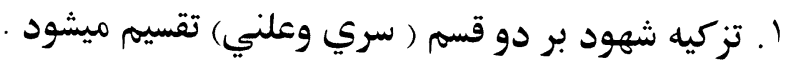

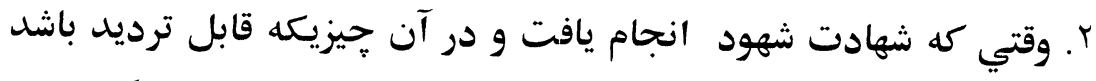
در شهادت شان ديده نشد لازم كه قاضي از مشهود عليه بيرسد كه تو در

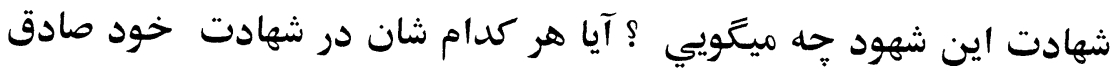

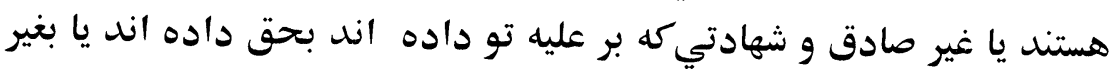

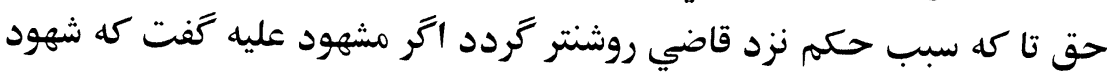
متذكره در شهادت خود صادق هستند سبب حكم قاضي اقرار است نه نه شهود

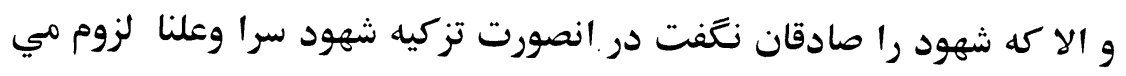
يابد .

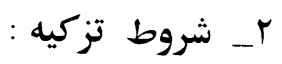

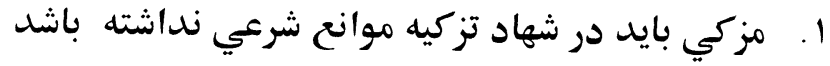

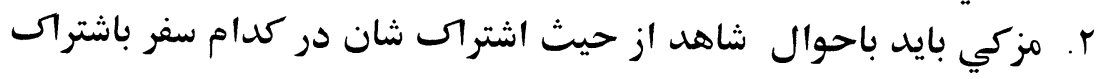

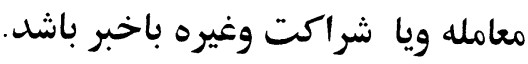

r. اتر شاهد مسلمان باشد بايد مزكي ادا نمودن فرايض الشه راند در نظر ترفته باشد

ז. لازم كه شاهد بخوبي معامله در خريد وفروش شهرتي داشته باشد .

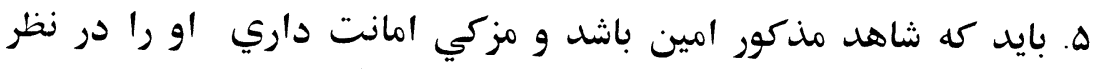
خيرد. 7 . بايد مزكي راست تفتاري شاهد را در نظر داشته باشد .

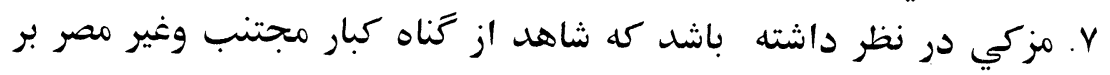
صغاير باشد. 
ه. مزكي بايد شخصي را كه در مدت كمي در موضع بود و باش مزكي

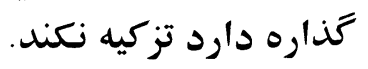
9. لازم است مزكي بله تمام افعال و واعمال و كردار و و رفتار شخصي كه تزكيه ميشود واقف باشد. • 1.

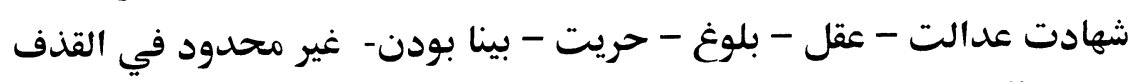

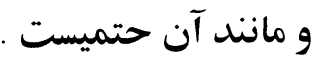
11. در تزكيه سري اكر حانده تزكيه يكنفر كفايت بتواند اما دو نفر احتياطا

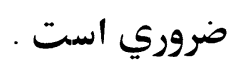

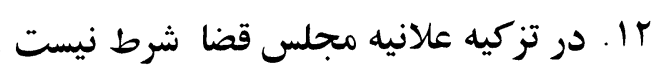

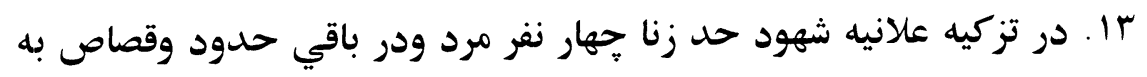

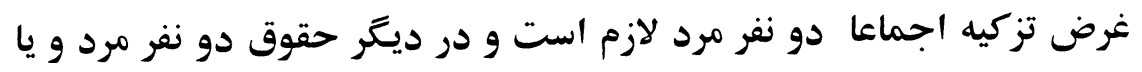

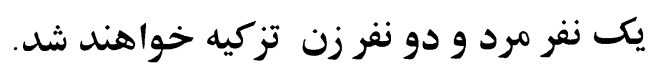

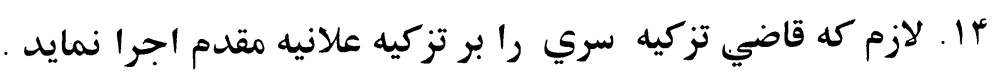

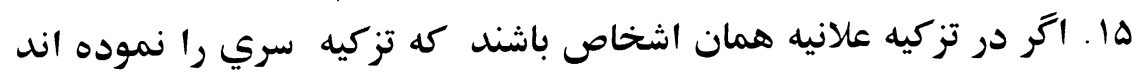

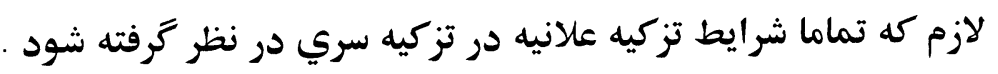

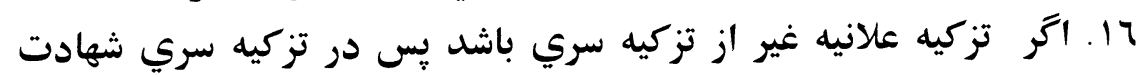

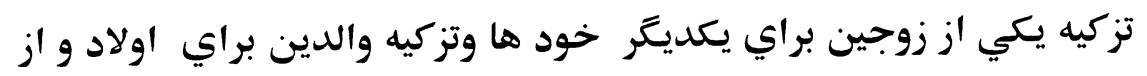

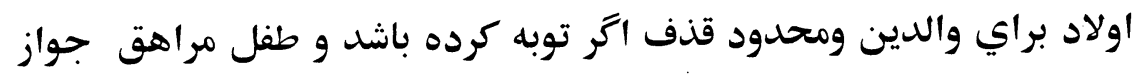
دارد. Y Vا. تزكيه سري از كساني شده ميتواند كه شاهد بانها ارتباط داشته باشد

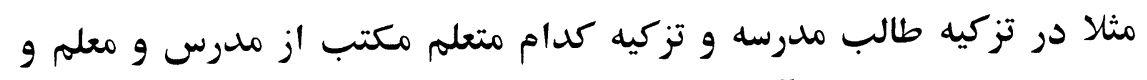

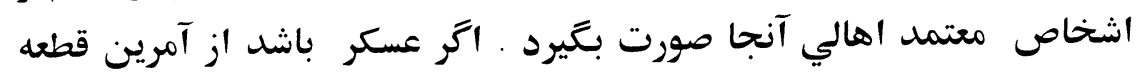

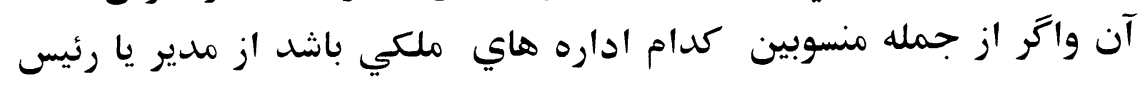
r. 


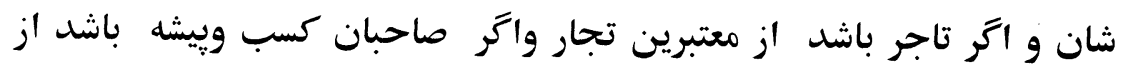

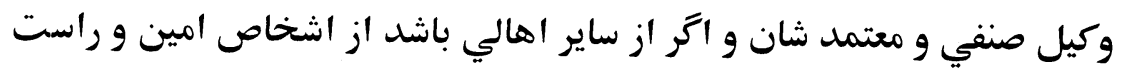

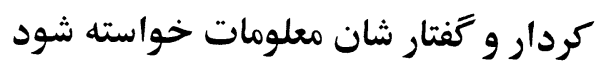

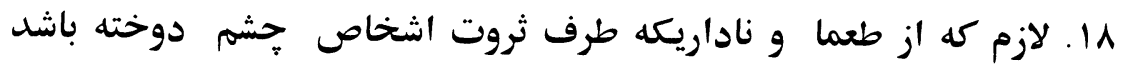
تزكيه شاهد خواسته نشود.

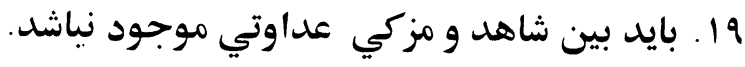

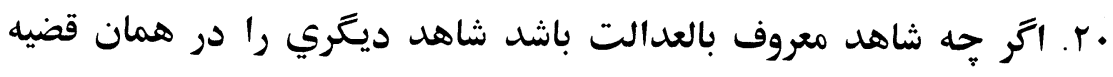

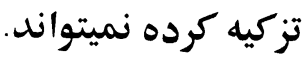

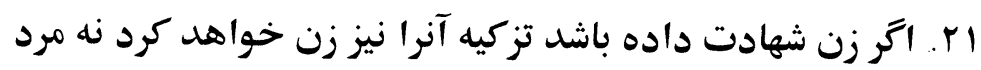

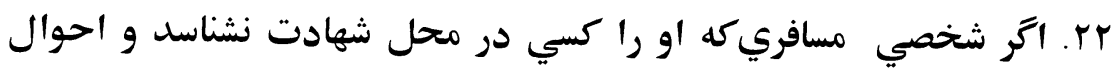

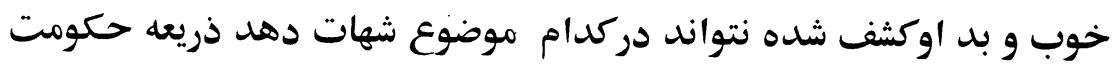
از قاضي محل مسكونه اش تزكيه خواهد شد .

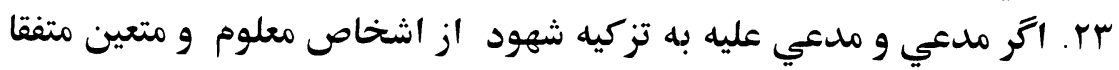

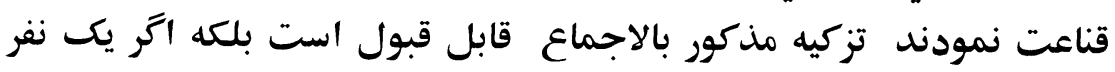
قناعت داشتند قبول شده ميتواند.

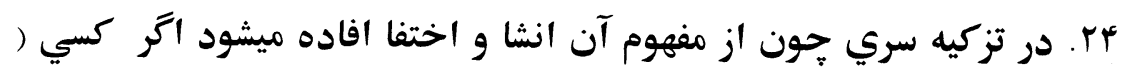

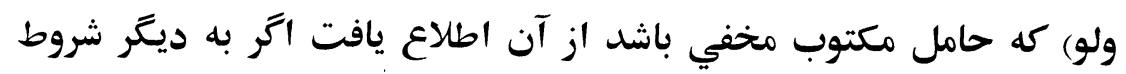

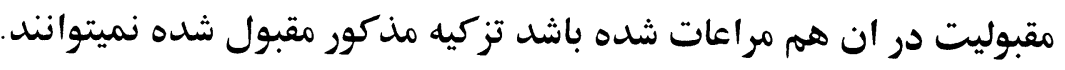

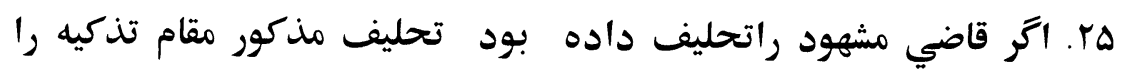

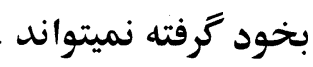
جr. قضاياي كه بدون تزكيه سري وعلني باشد نزد محاكم فوقاني قابل

$$
\text { نقـ صورت است ـ براي تزكيه : }
$$


1- در تزكيه سري وعلني لازم كه قاضي محكمه به شخص وحضور خود

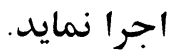

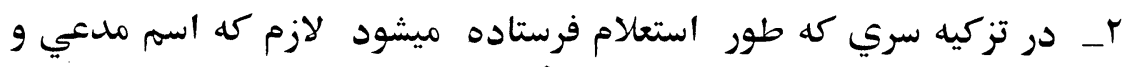

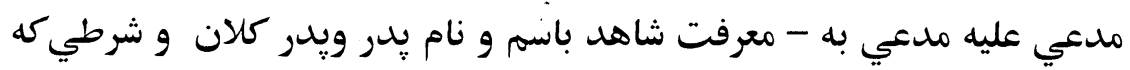

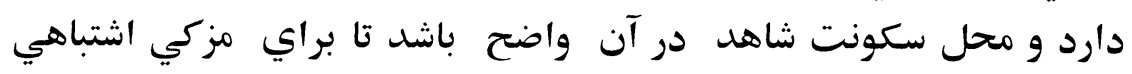

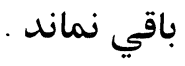

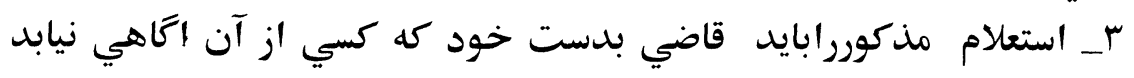

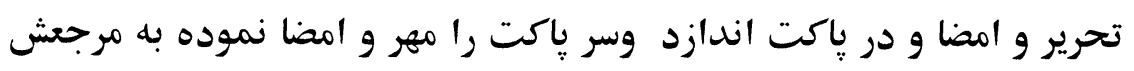

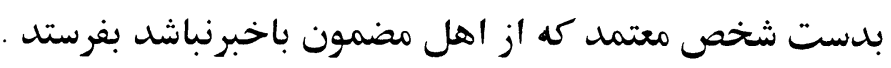

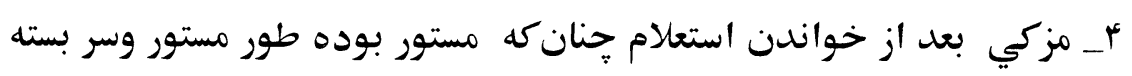

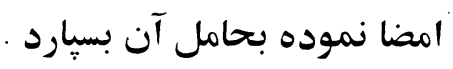

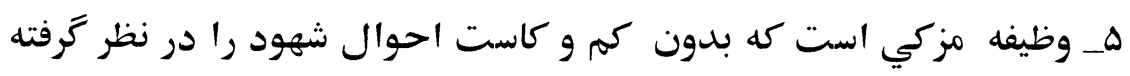
خوب و بدي شهود را واضح سازد

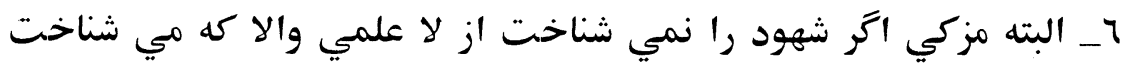

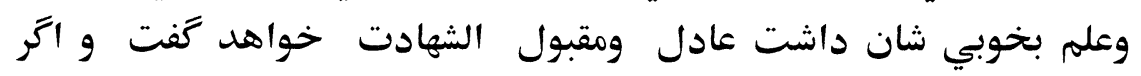

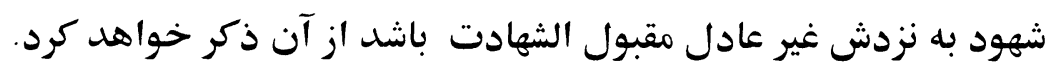

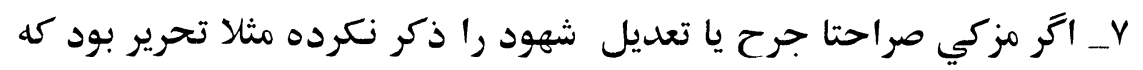

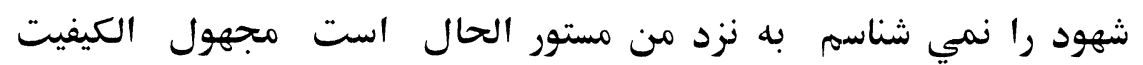

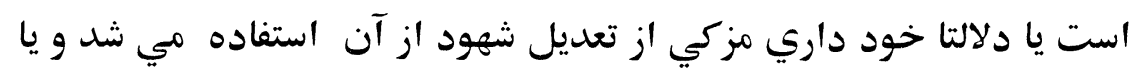

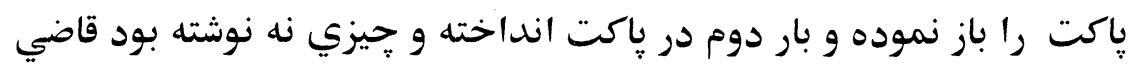

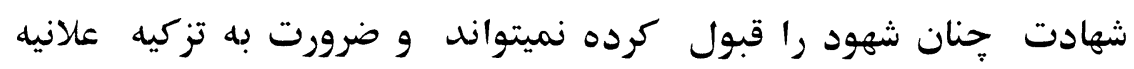

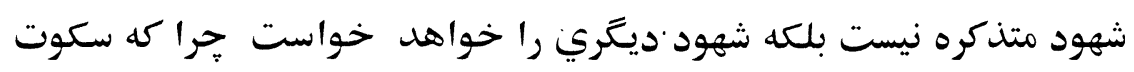

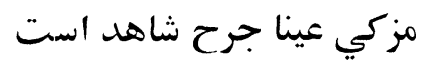


^_ اتر دو نفر تعديل و يكسنفر جرح نمودتعديل مقدم و .الا كه يكسنفر

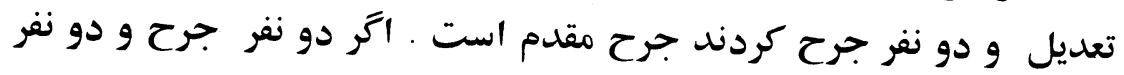

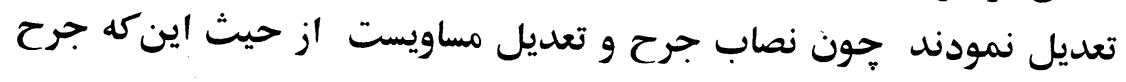

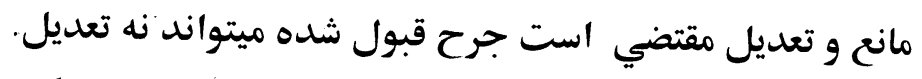

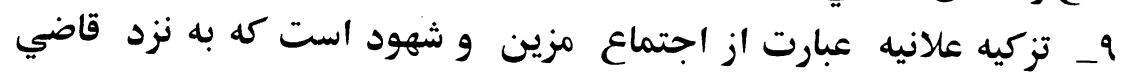
بحضور شهود اصل و مزين علنا تزكيه ميشود .

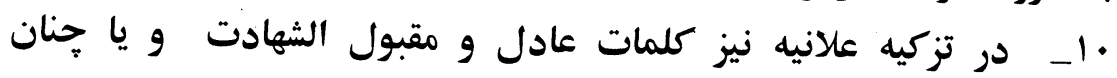

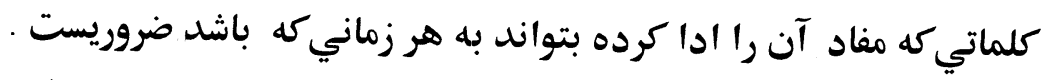

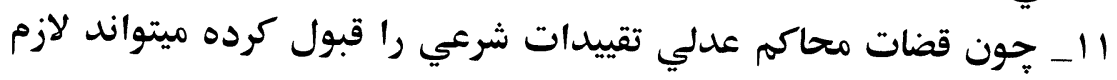

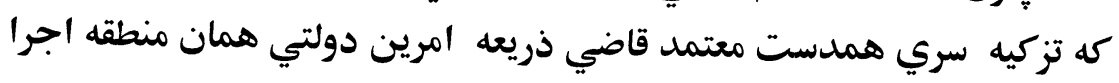

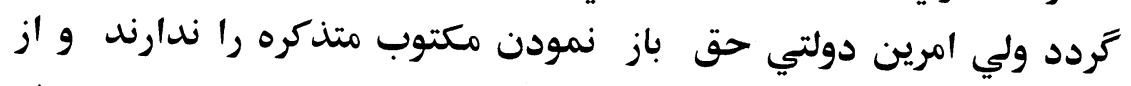

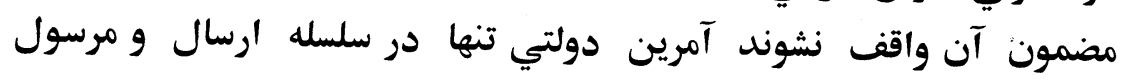

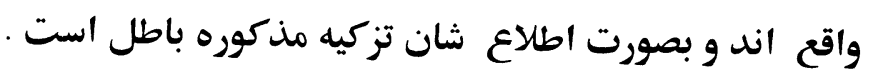

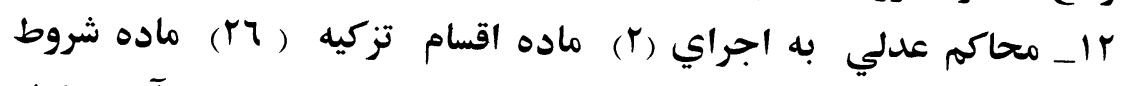

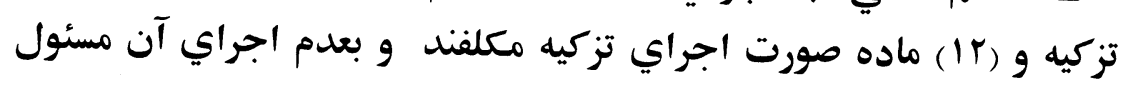
اند.

نوت : تعليمات نامه تزكيه شهود توسط فرمان شماره ( ( 19

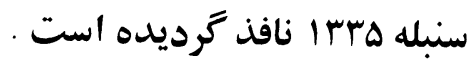

VT ton 
اقتباس از منابع عربي

تبع و نمكارش :

مولوي عبدالبصير "فائز"

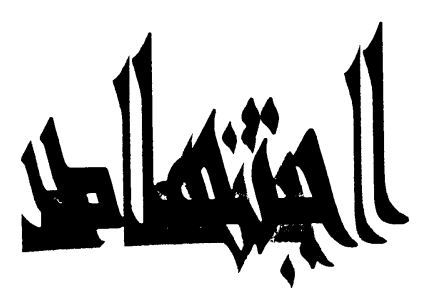

مقلدمه :

اجتهاديك اصل عمده وخيلي مهم از اصول شريعت كامل و جاويد اسـلام اسـت

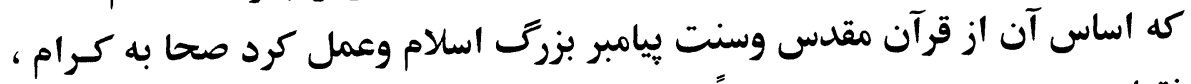

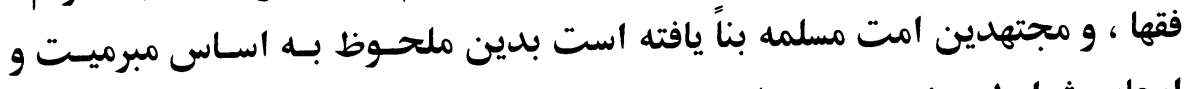

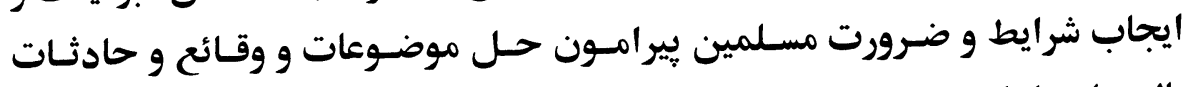

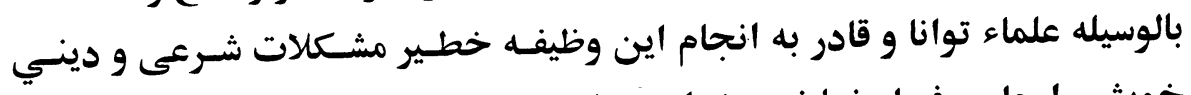
خويش را حل و فصل نمايند . خواستم با تتبع و تحقيق و با استفاده از كتب معتبر

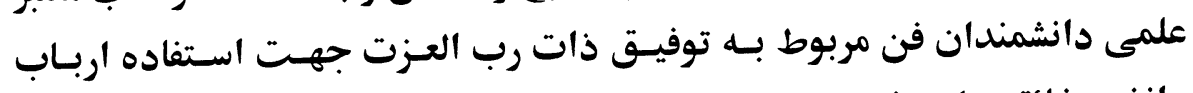
دانش وشائقين اين فن روى مباحث ذيل طور فشرده و قابل اسـتفاده بـراى دئ عـام مردم با سواد روشنى باندازم : ا : تعريف ، بيان مشروعيت واقسام اجتهاد.

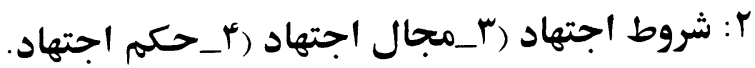

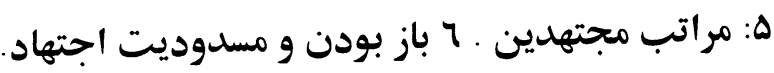

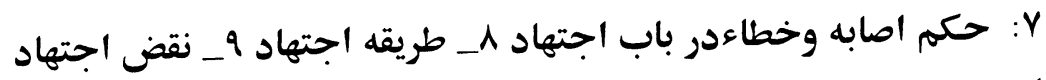

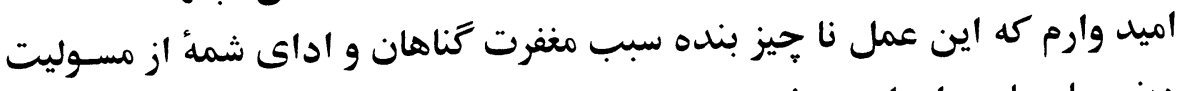

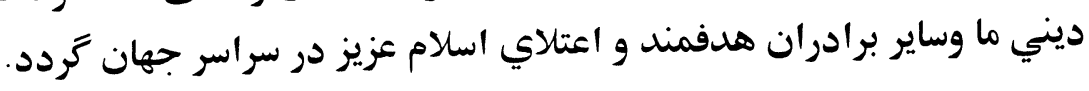




\section{تعريف اجتهاد :}

اجتهاد درلغت : عبارت است از سعى و كوشش در تحقيق و تبتـع امـرى از امسور.

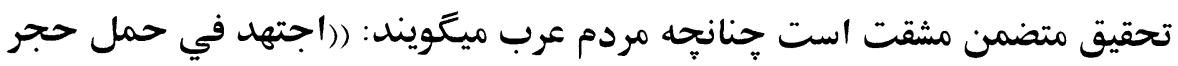

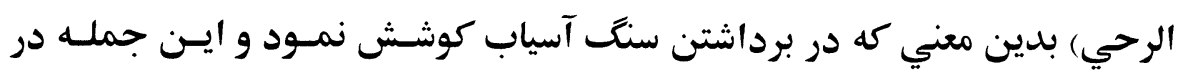

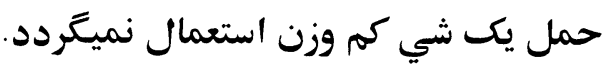

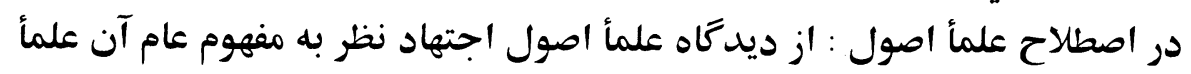

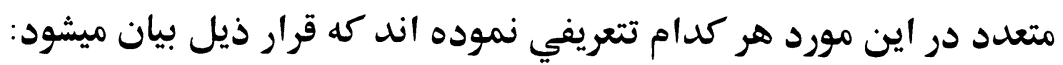

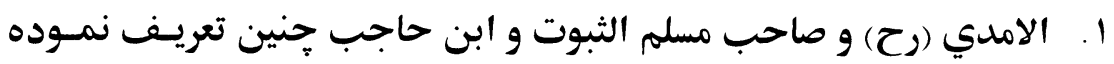
اند:

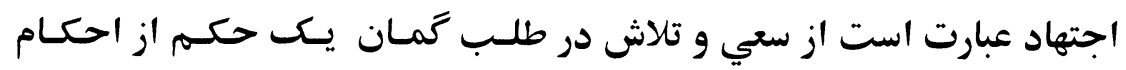

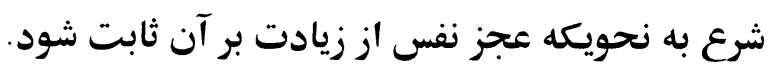

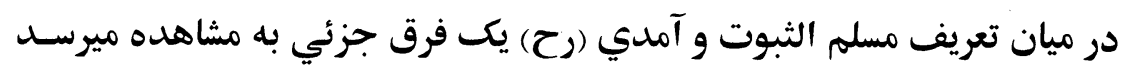

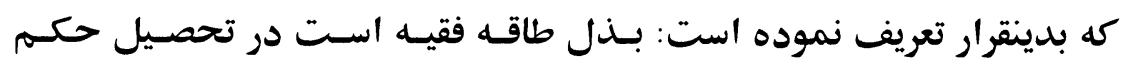

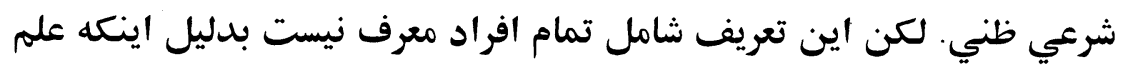

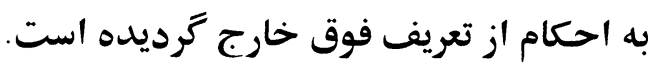

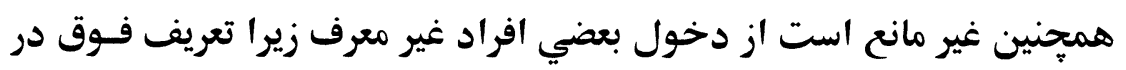

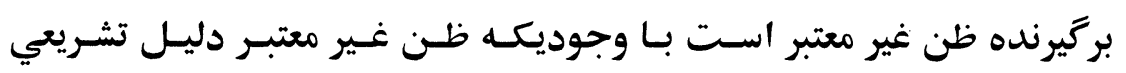
نميباشد.

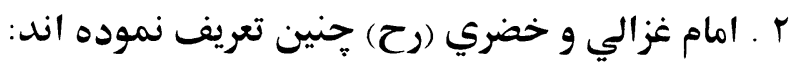

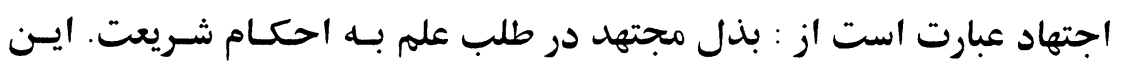

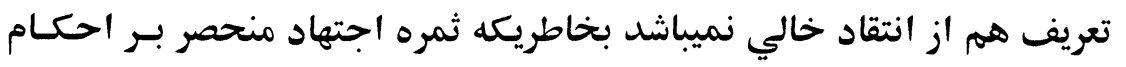
يقيني نبوده بلكه اغلب آن ظني ميباشد. تميل 


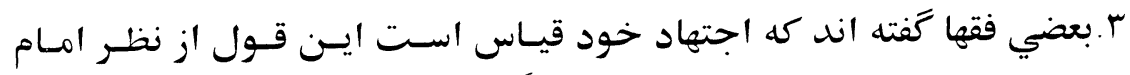

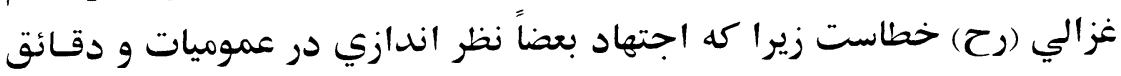

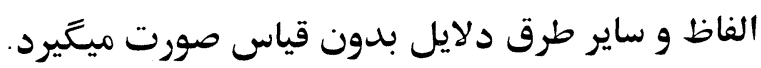

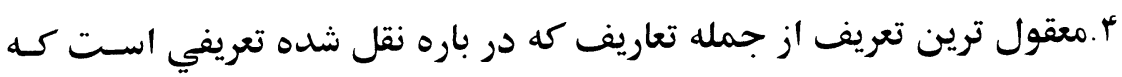

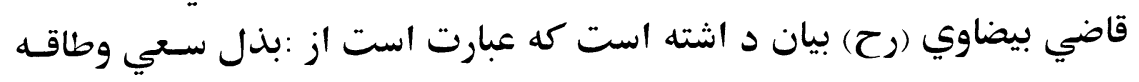

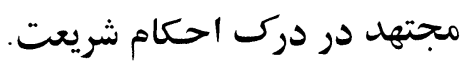

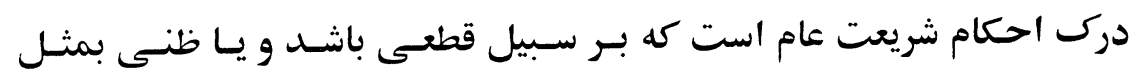

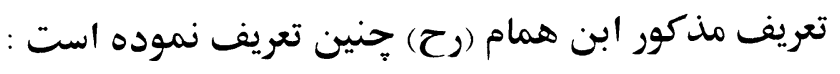

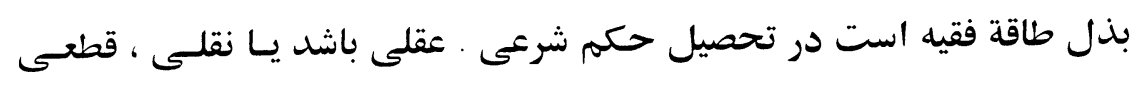

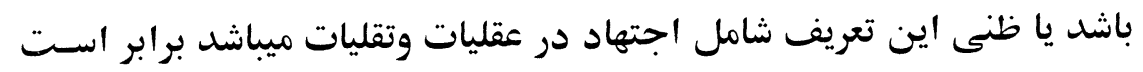

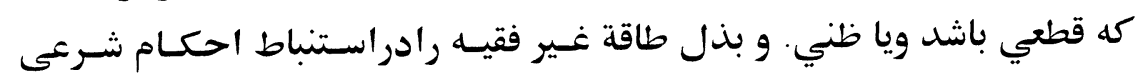

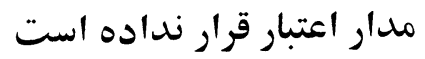

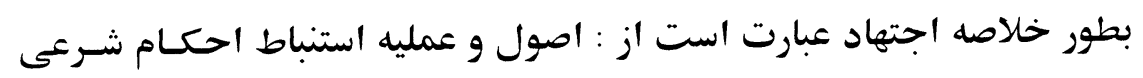

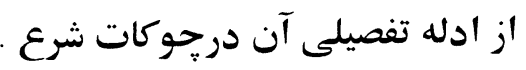

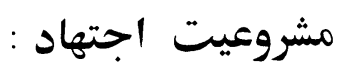

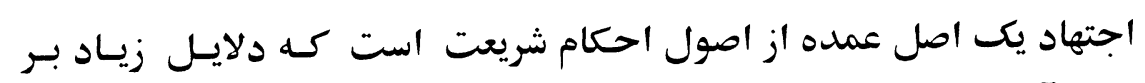

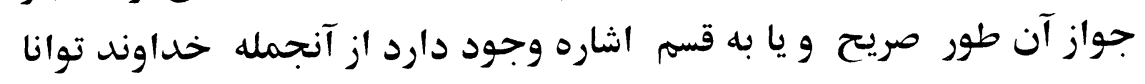

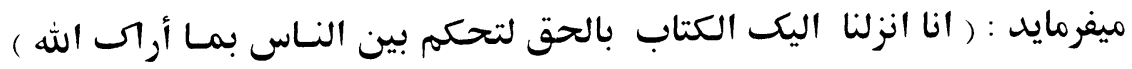

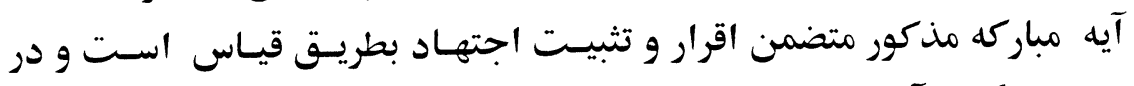

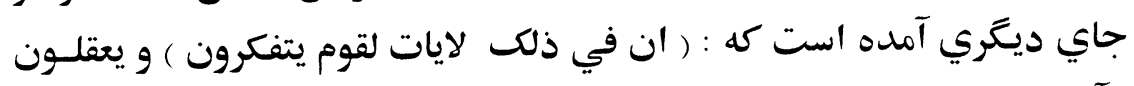

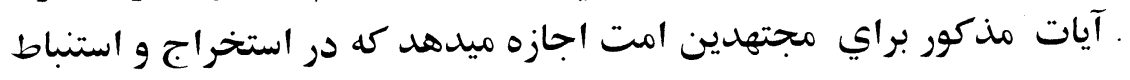

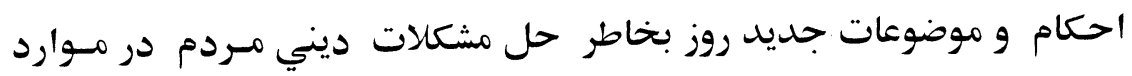

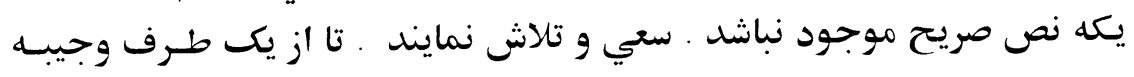




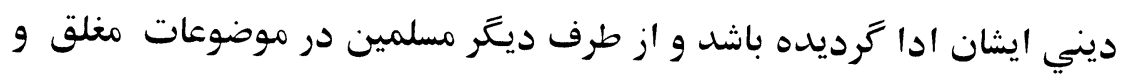

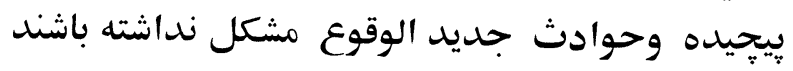

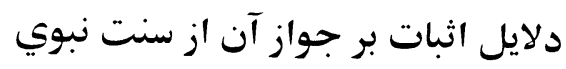

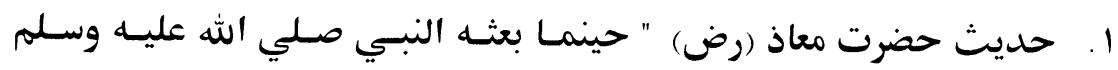

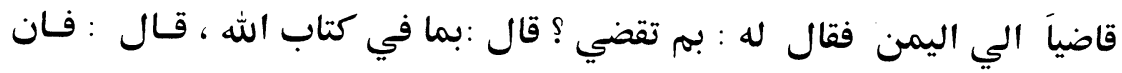

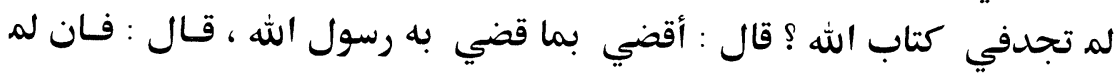

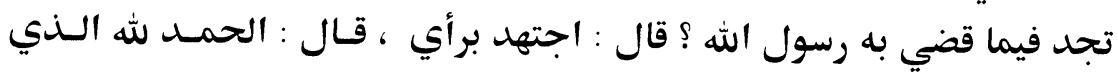
وفق رسول رسوله

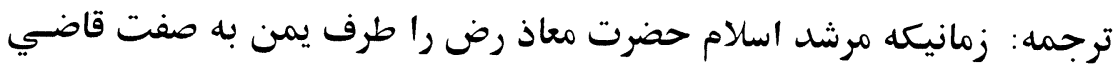

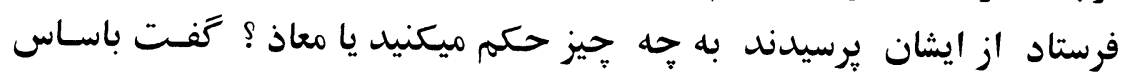

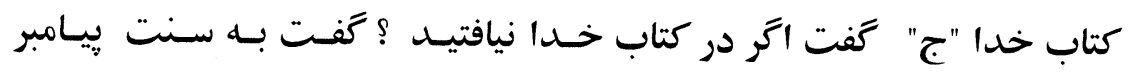

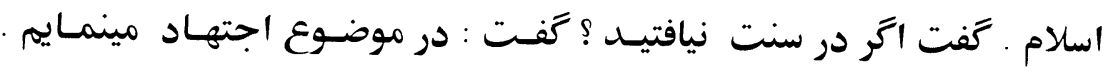

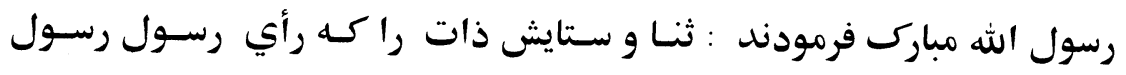
خويش برابر نمود .

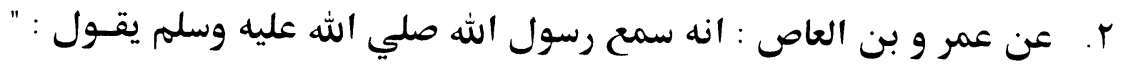

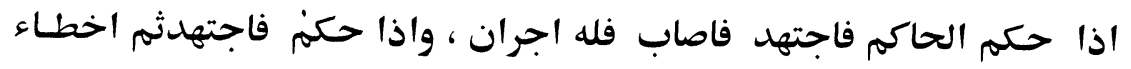
فله اجر.

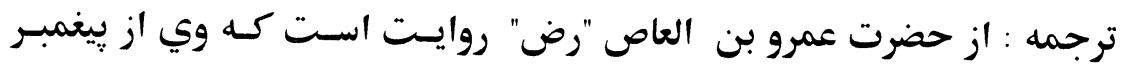

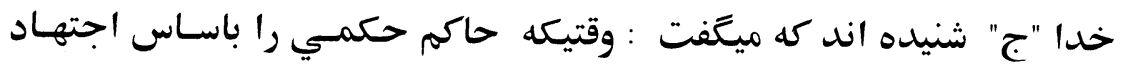

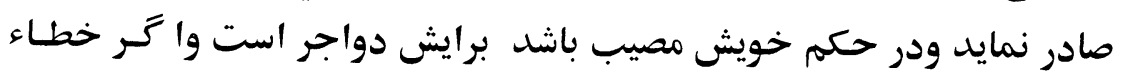
نمايد برايش يك اجر است لمايد

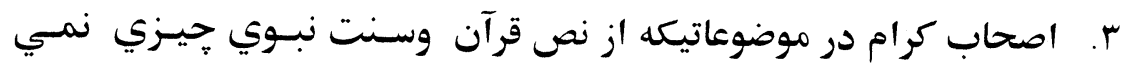

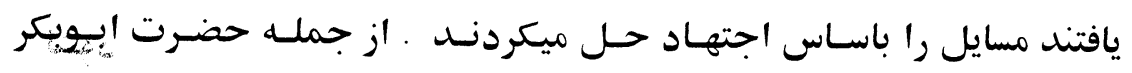




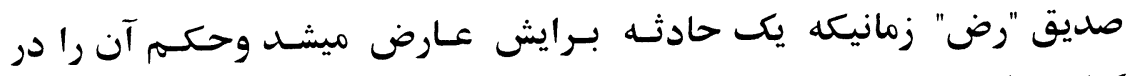

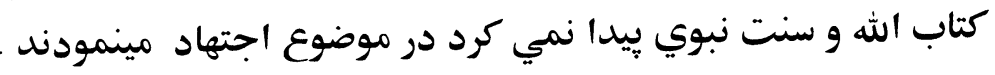
اقسام اجتهاد :

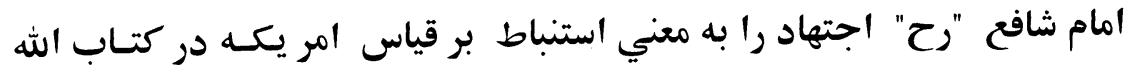

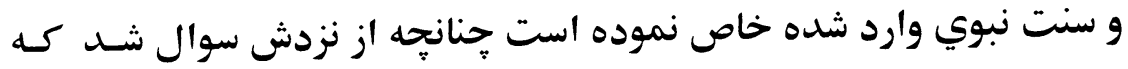

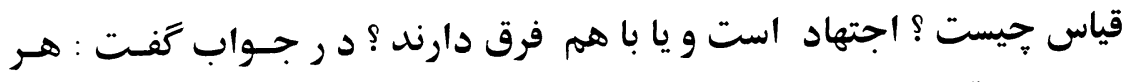

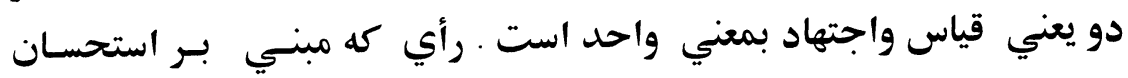

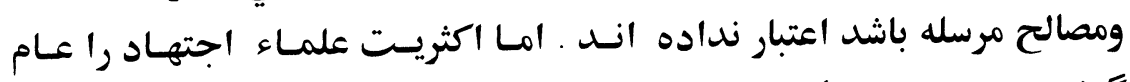

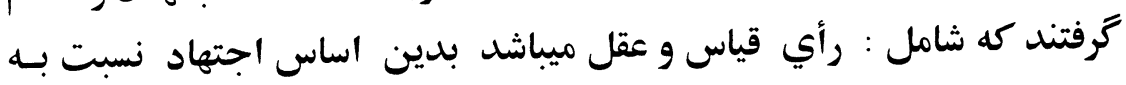

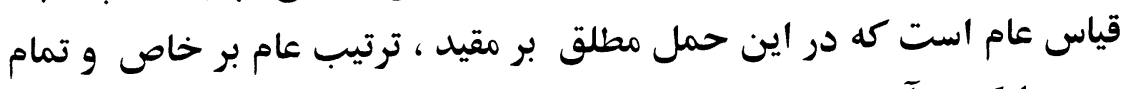

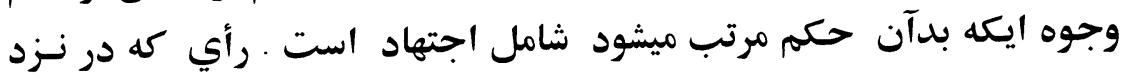

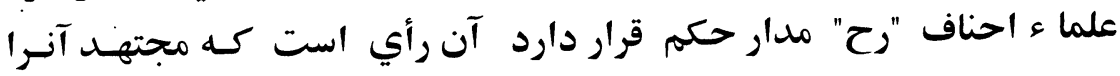

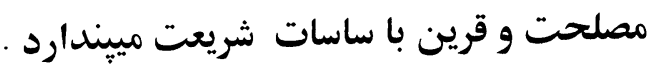

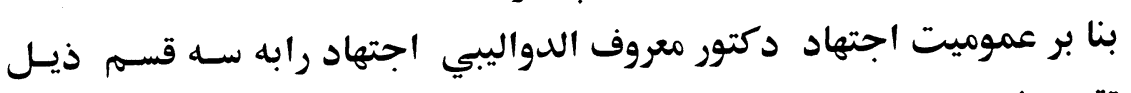
تقسيم نموده

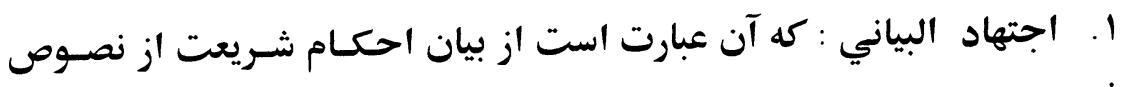
شرع r. اجتهاد قياسي: اين بمنظور وضع احكـام شـريعت بـراي وقـائع حادثــ

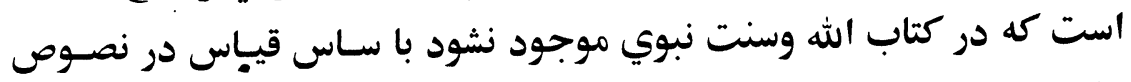

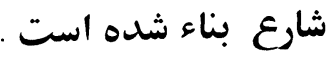

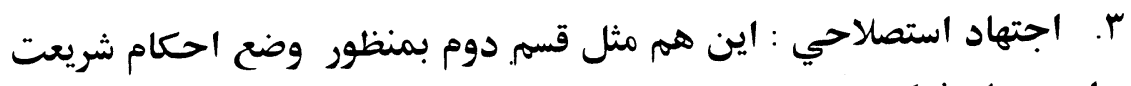

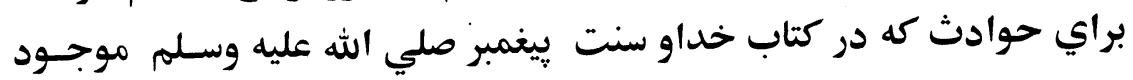

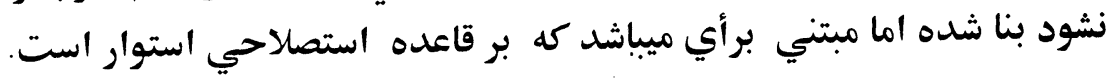


بخاطر يكه تقسيم فوق مبرا از نقد نيست .الا ستاذالحكيم اجتهاد را بـه دو

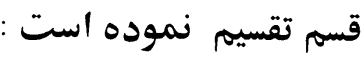

1.اجتهادعقلي:كه حجيت آن باساس مصادر عقلي محسض ثابـت شـده است . است

مثل مستقلات عقلي ، قواعد لزوم دفع ضرر محتمل ، قباحـت شـكنجه و

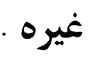

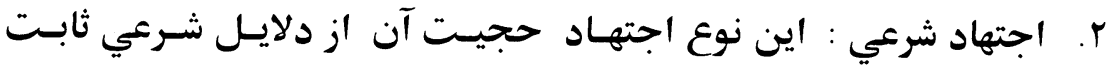

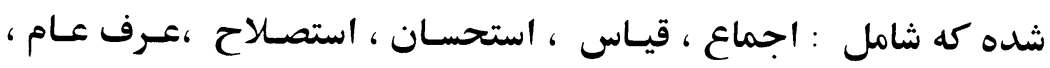

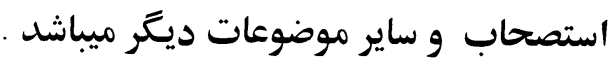

$$
\text { ادامه دارد }
$$

(Y9) 


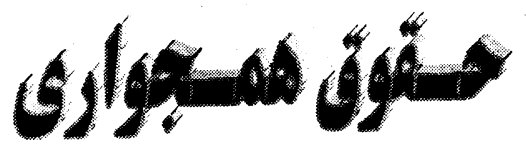

در شريعت اسلام وقانون مدني افغانستان قواعدمر بوط بــه رعايست حقـوق آست

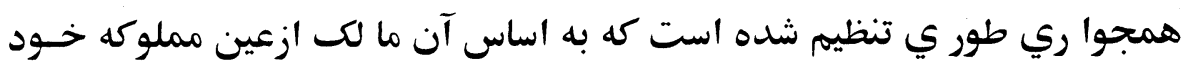

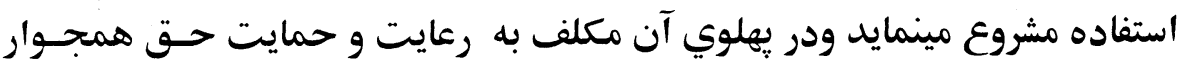
برملكيت خود مي باشد.

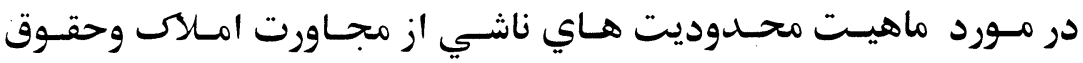

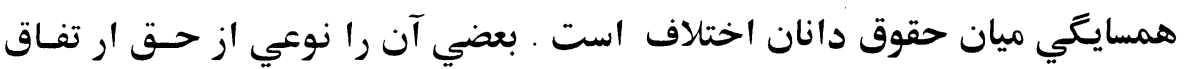

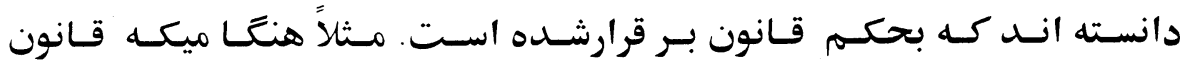

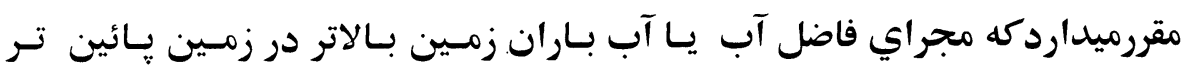

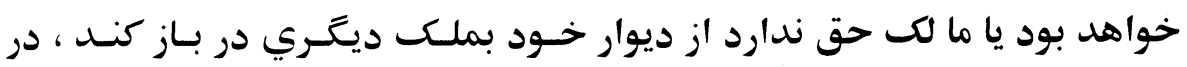

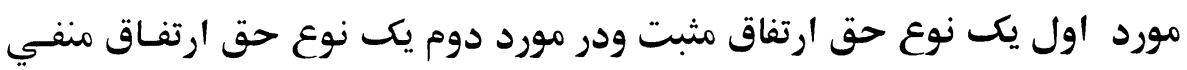

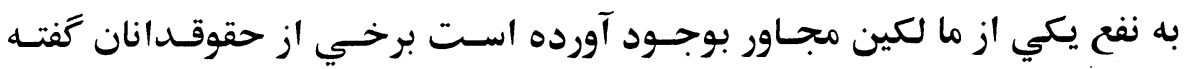

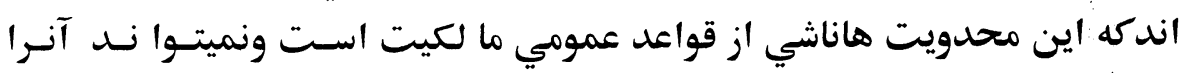

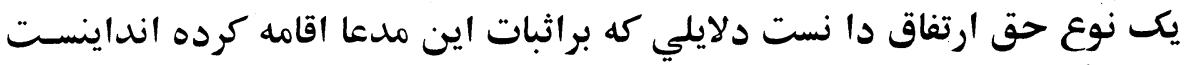

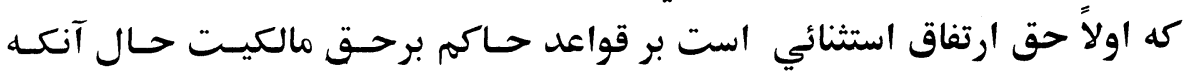

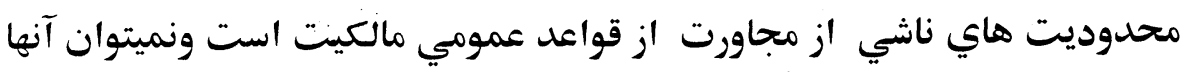

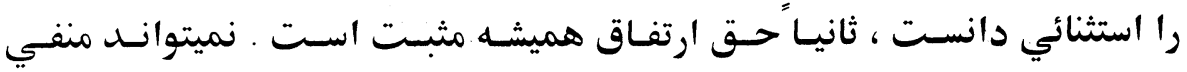

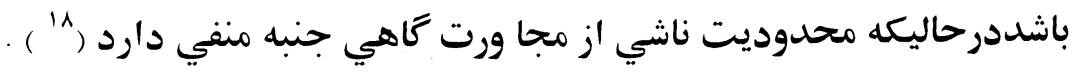

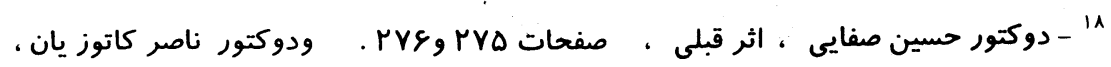

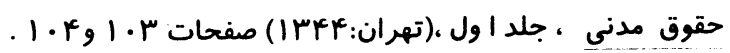
A. 


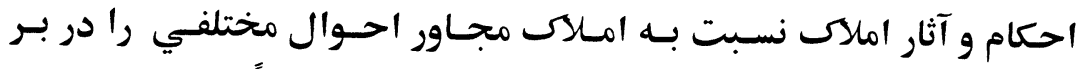

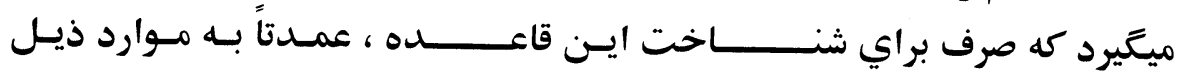
اكتفامي تردد : ميتيرد كه صرف

الف - فاصل مشترك يا ( حدفاصل ) .

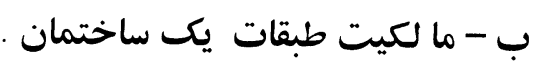

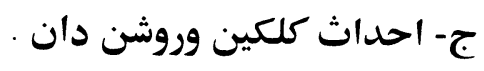

$$
\text { د - د - دفع ضرر }
$$

اول: فاصل مشترك يا (حدفاصل )

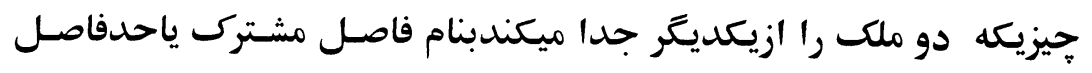

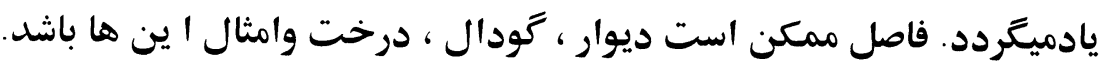

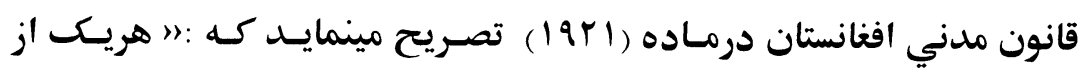

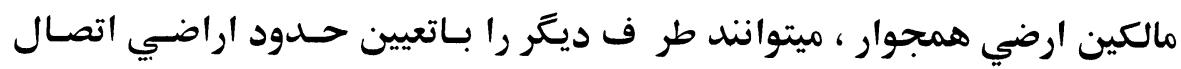

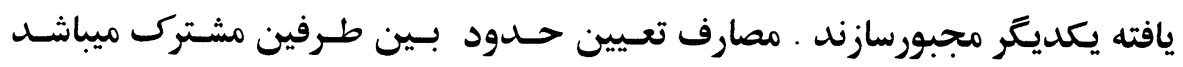
( $\left.{ }^{19}\right) . " 1$

"مطابق حكم ماده (191191) مجلـه الاحكـام العدليـه وشـرح آن ( الاتاسسي):

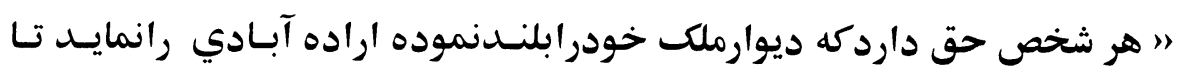

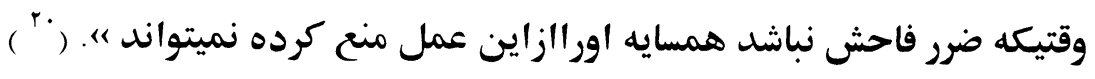

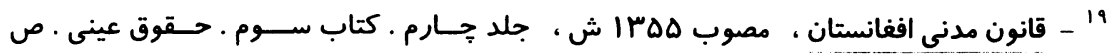
( $(8 \cdot 9)$

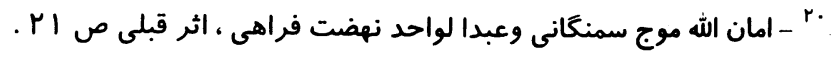
(1) 1 1 
در شرح اين ماده آمده است كه : " زعم همسايه نسبت به سدشدن باد و

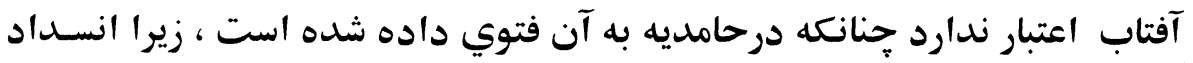
هوا وآفتاب از جمله ضرر فاحش نيست .

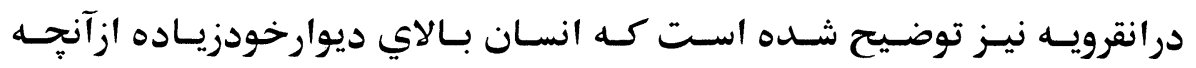

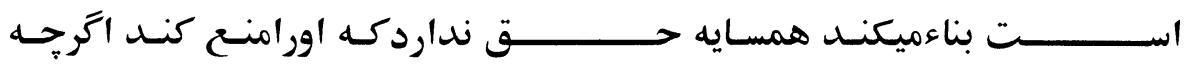

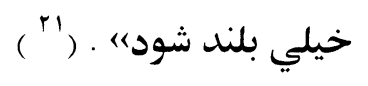

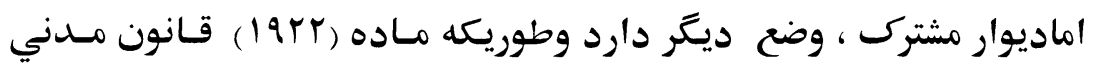

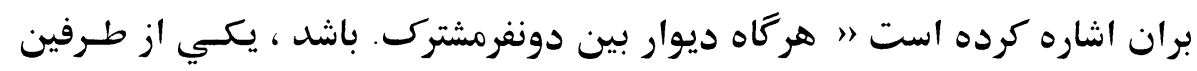

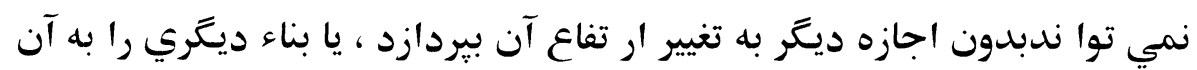

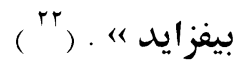
در ارتباط ديوا رمشترك وحقوق ناشي ازان قواعد ذيـل در قـانون مــني تسجيل يافته است :

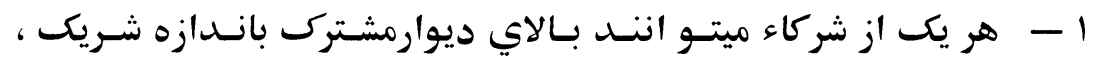

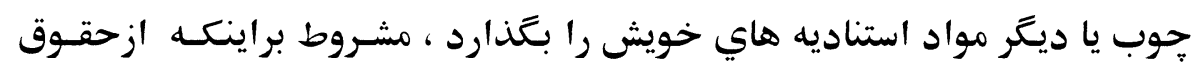

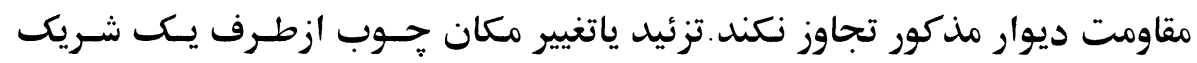

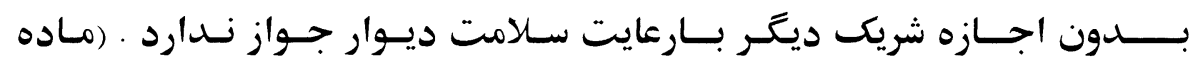

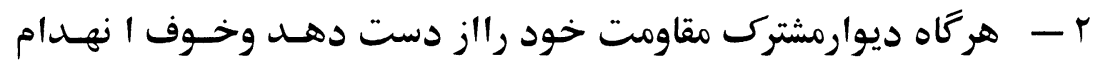

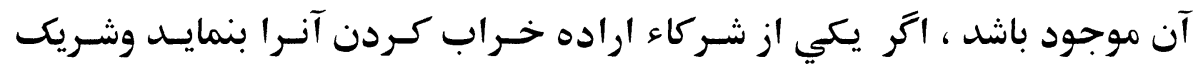

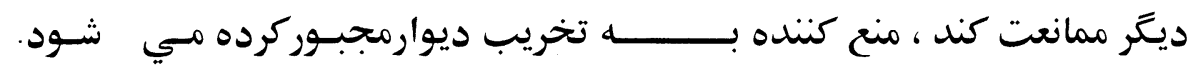
. (19+4)

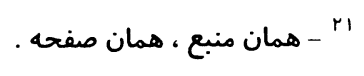

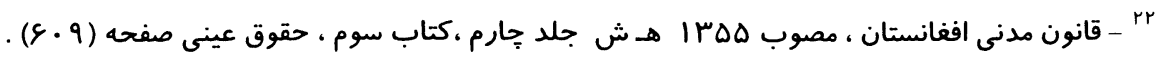

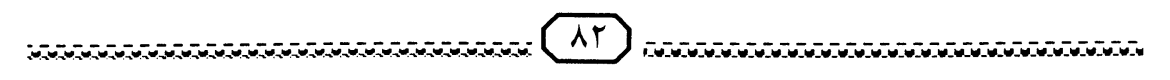




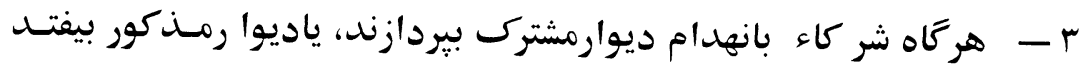

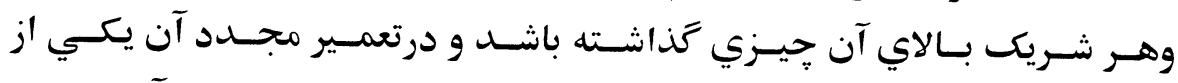

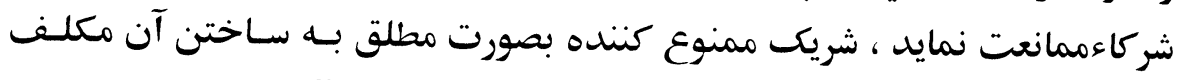

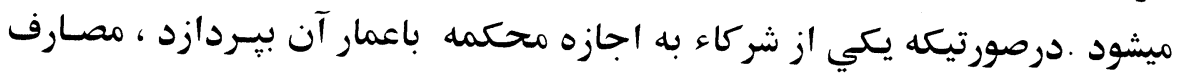

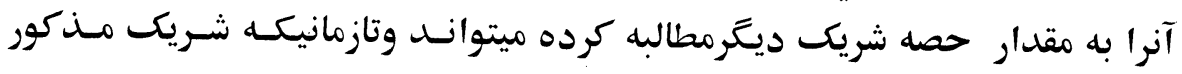

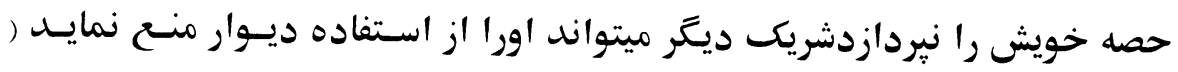
ماده (19T0

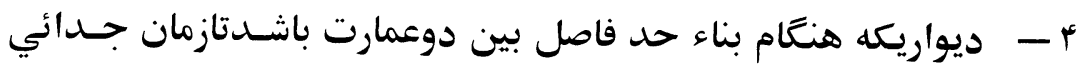

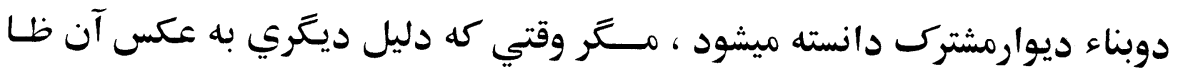

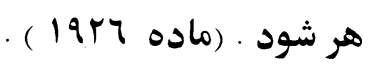

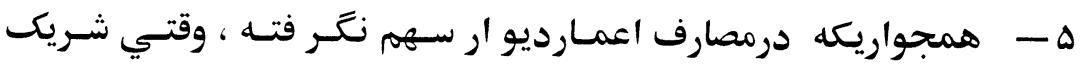

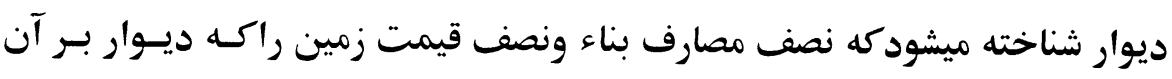

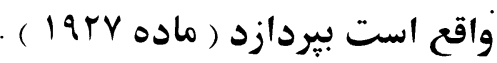

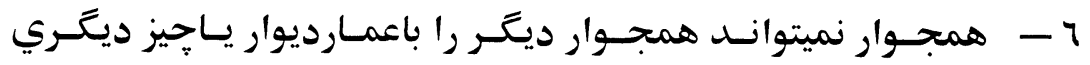

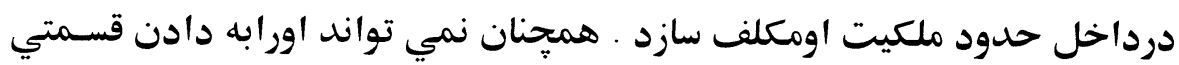

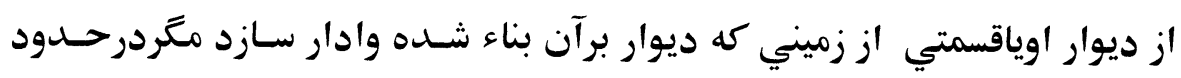

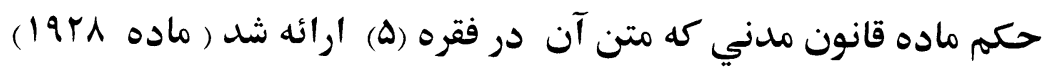
دوم: مالكيت طبقات يك ساختمان

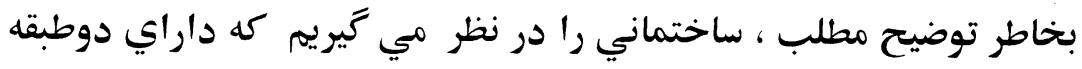

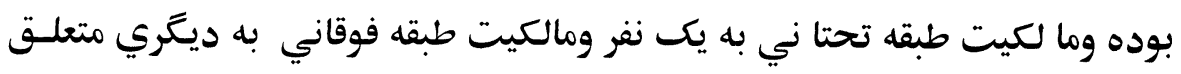

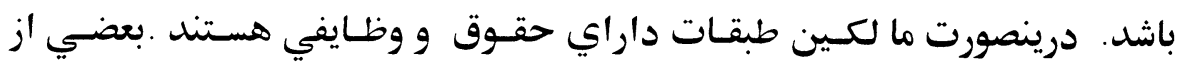

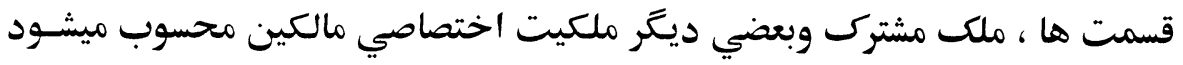

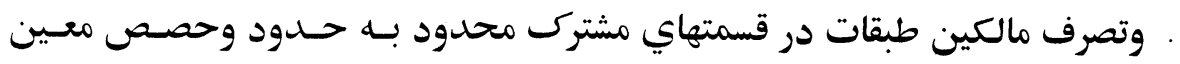


قاعدتاً هر طبقه ملك اختصاصي ما لك آن 1 ست ، مترقسمتهاي كه منورد استفاده مشترك هردوما لكس باشد بنابرآن :

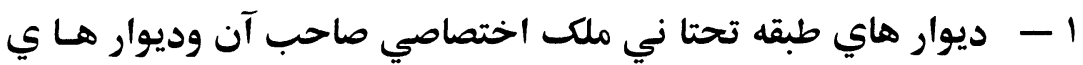
طبقه فوقاني مال مالكـ اين طبقـه محسـوب ميشـود وسـقف مـابين دواتـاق ونيـز

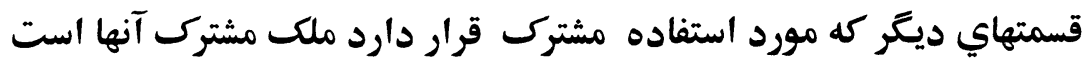

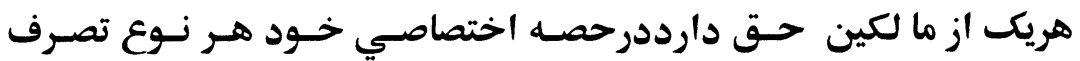
متعارف رابعمل آردامادر قسمتهاي مشترك ، هريك از ما ما لكين باندازه اي دارداي

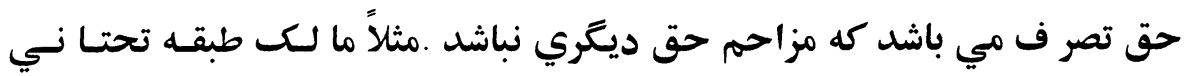

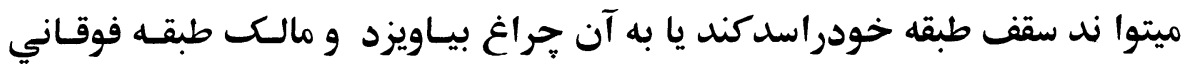

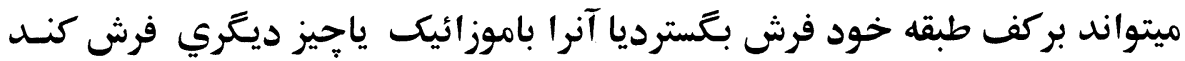

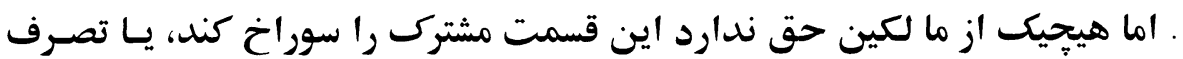

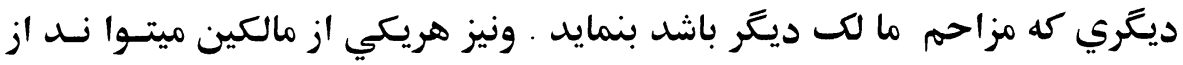
آب انبار آب ببرداماحق ندارد يله هارا خراب كند و بدينطريق مزاحم مالك ديَّر شود . ( در زمينـه ملكيـت طبقـات منـازل وحقـوق مــتبط بـه آن قـانو ن مسدني افغانستان طي مواد متعدد قواعد ذيل راتنظيم نموده است :

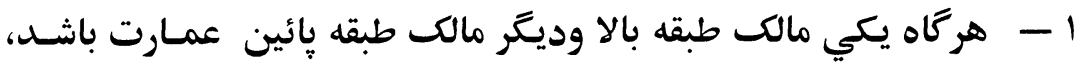
مالك طبقه بالاحق قرار برسقف داشته وسقف ملكيت مالك طبقه يـائين شـناخته ميشود.

مالك طبقه بالا از سطح آن بصورت معتادحق استفاده رادارد مالك طبقـه

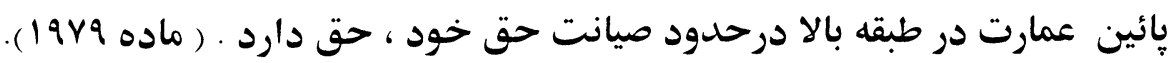

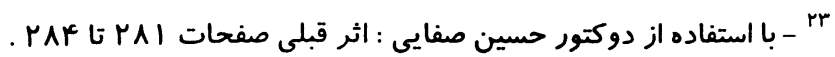

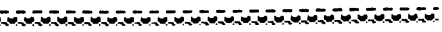
AF 


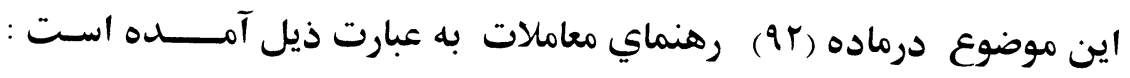

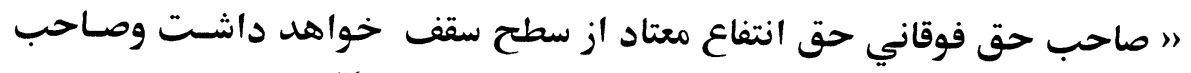

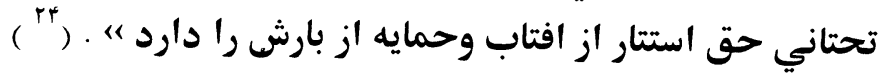

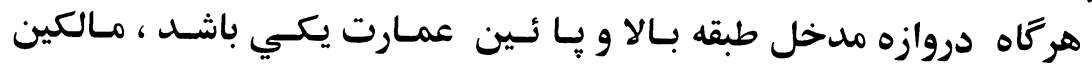

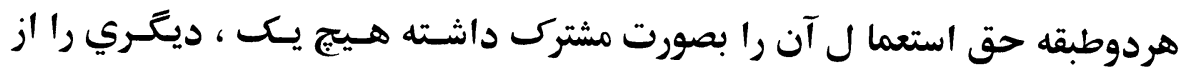

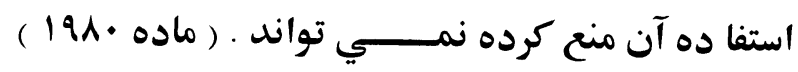

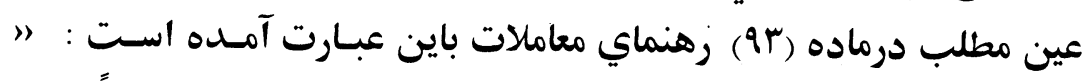

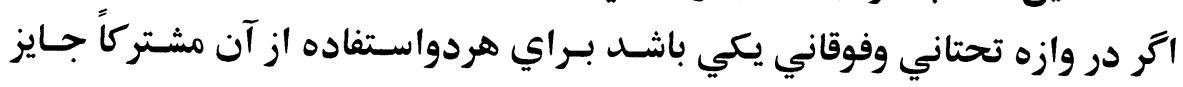

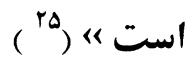

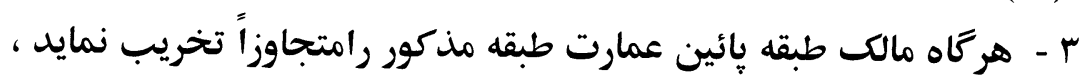

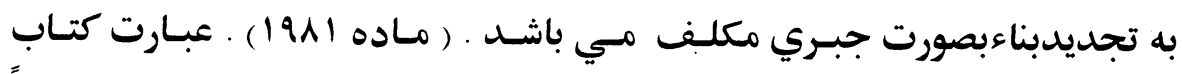

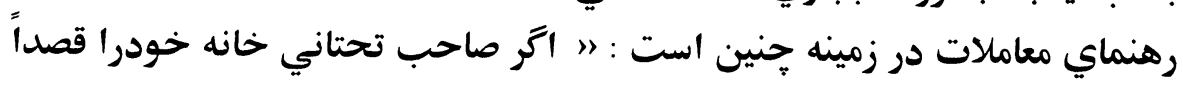

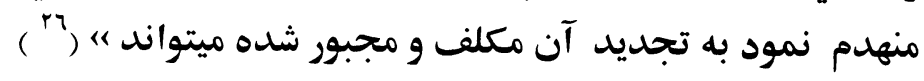

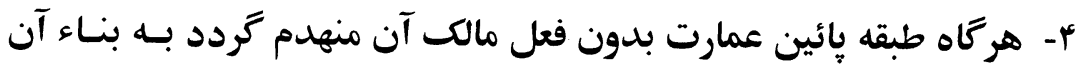
مكلف مي باشد . ماكر ماه

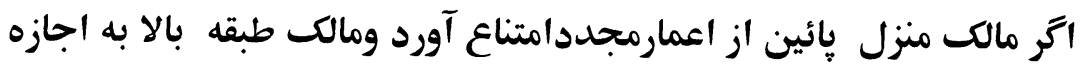

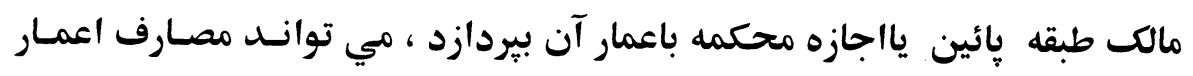

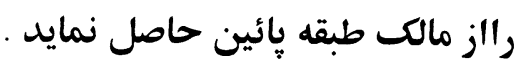

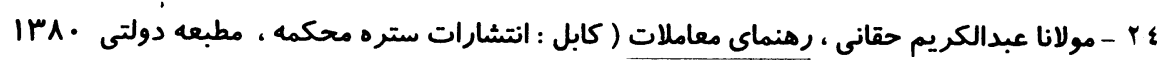

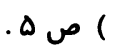
ه ب - مولا نا استاد عبدالكريم حقانى ، رهنماي معاملات ، ( كابل : انتشارات ستره محكمه مطبعه دولتى . D D (IrrA. צY 


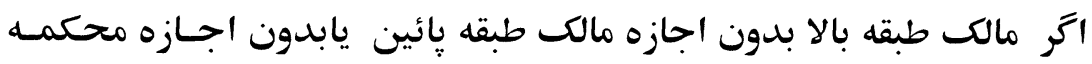

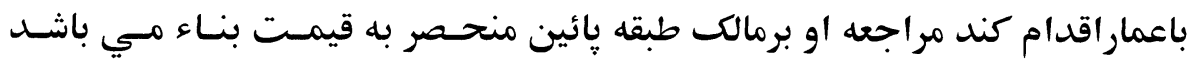

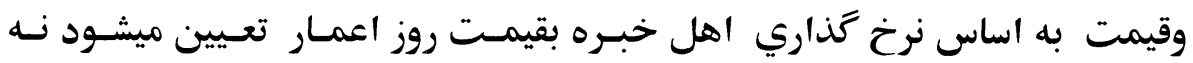

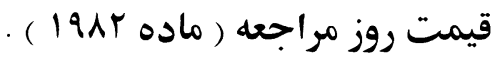

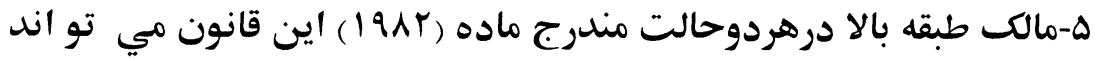

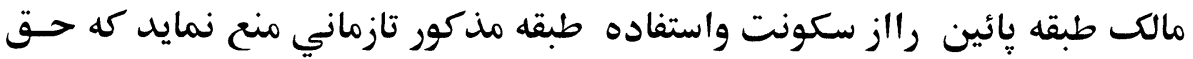

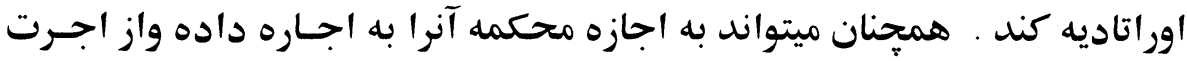

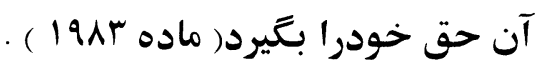

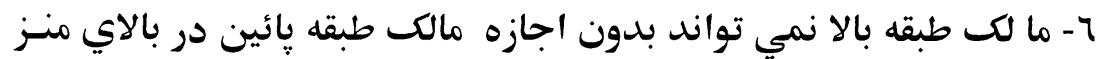

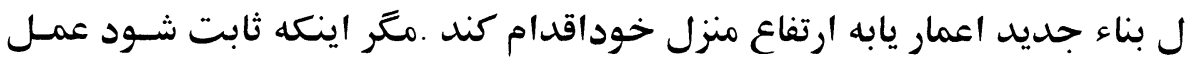

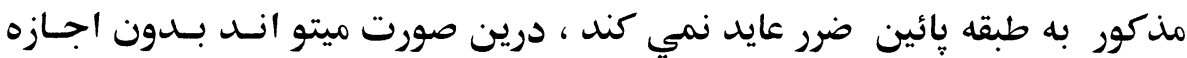

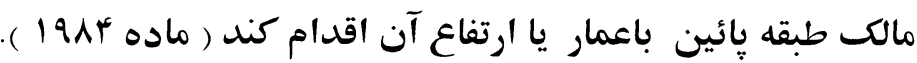
سوم: احداث كلكين و روشن دان بان

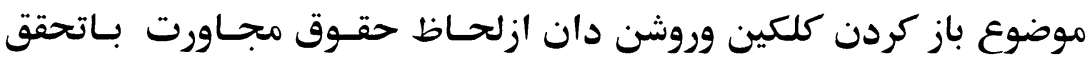
دوشرط مجاز است يكسي اينكه كلكين و روشــــــن دان در ديوار اختصاصي

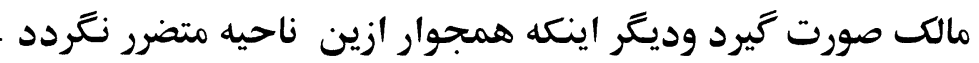

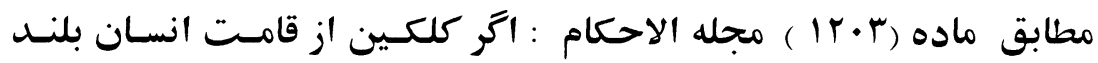

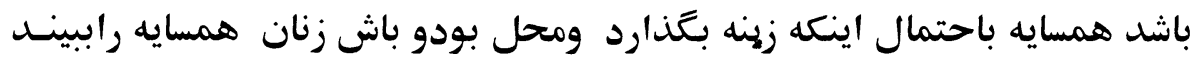
، شخص مذكور رابه انسداد آن مكلف ساخته نميتواند ( عين مطلب درماده (^9) رهنماي معاملات به عبارت ذيل تسجيل ترديده

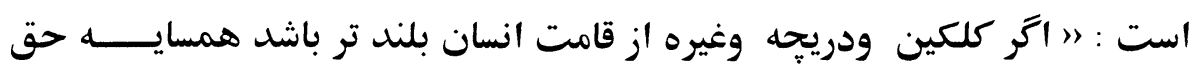

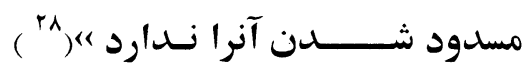

التشارات - TV امان الله موج سمنكانى و عبدالواحد نهضت فراهى ، شرح مجله الاحكام قسمت سوم شركتها ( كابل

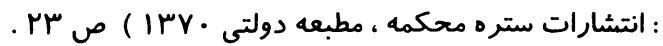


همجنان اتر كلكين هاي منزل قديم به ميدان خا لي مشرف وقابل ديسـن

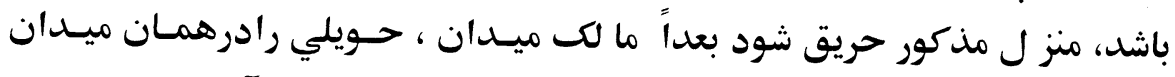

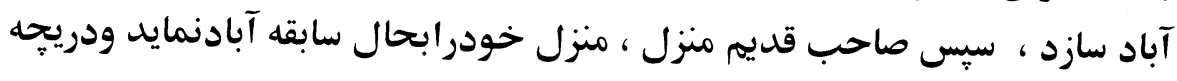

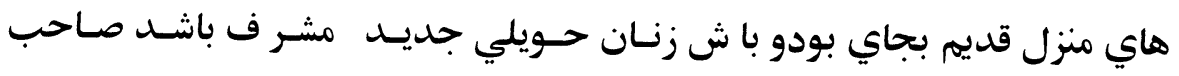

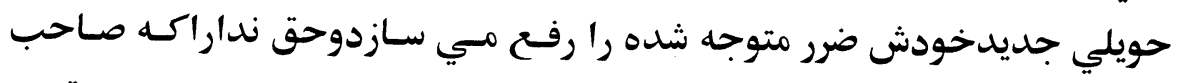

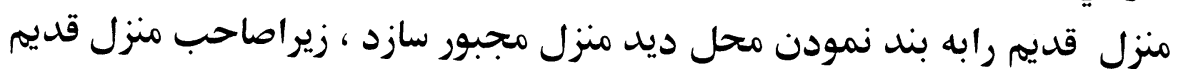

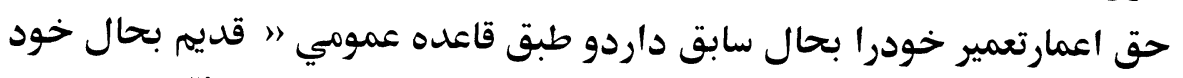

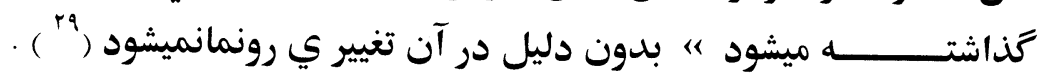

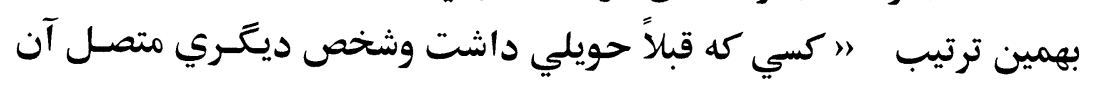

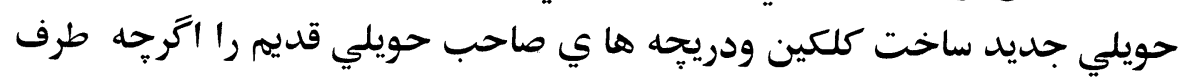

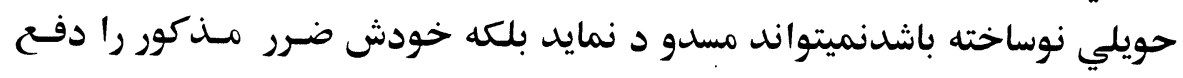

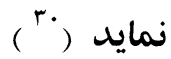

$$
\text { جهارم: دفــع ضرر فاحش }
$$

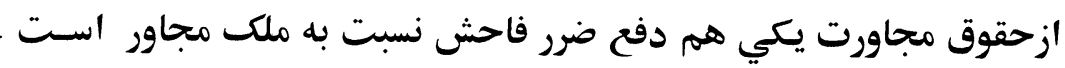

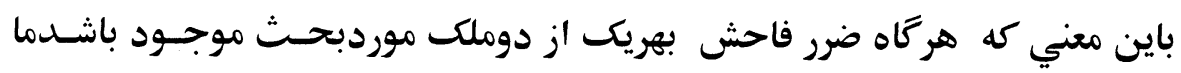

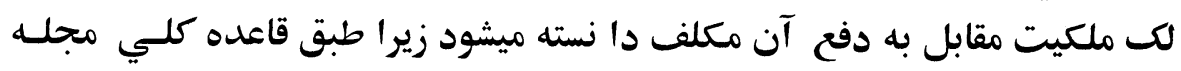

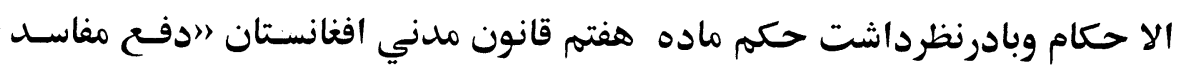

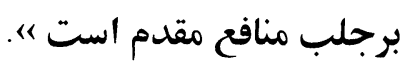

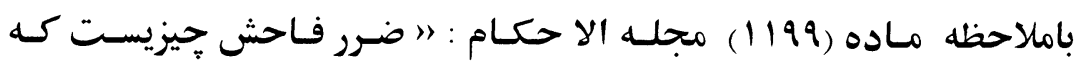

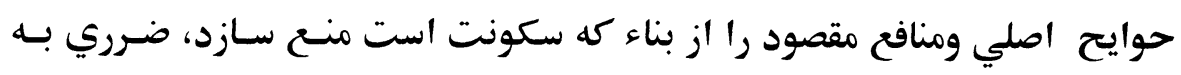

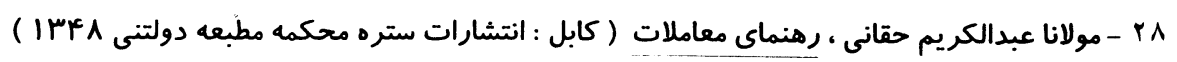

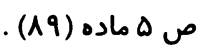

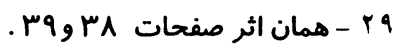

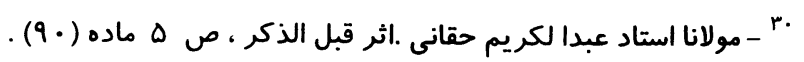
AY 
آبادي وتعمير واردشودكه موجب سستي وشكستن بناء شده سـبب خرابسي را بـار

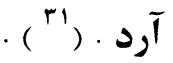

مسايل مر بوط به دفع ضرر فاحش حسالات مختلـف و تونـاتون را در بـر

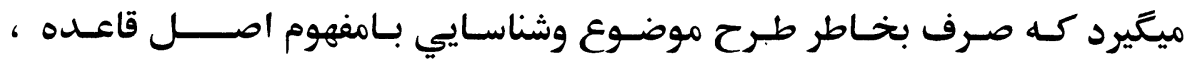

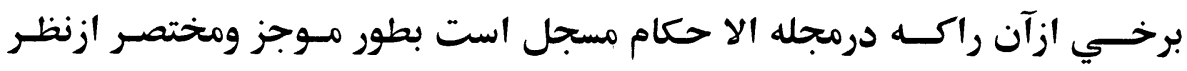

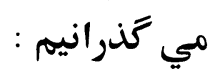

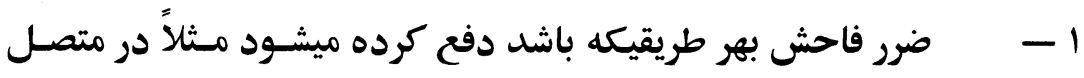

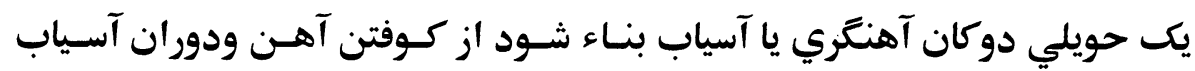

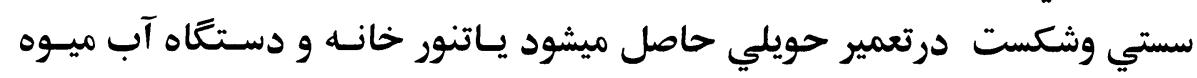

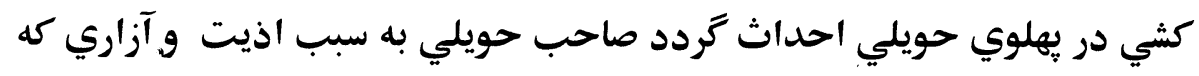

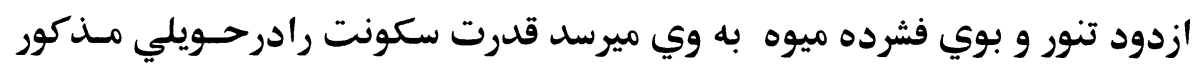

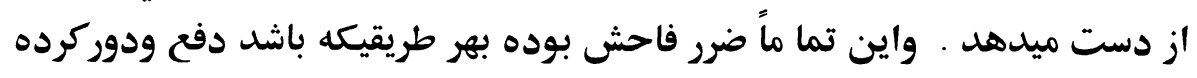

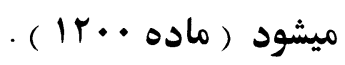

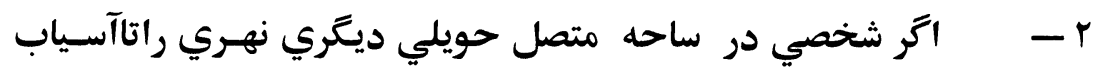

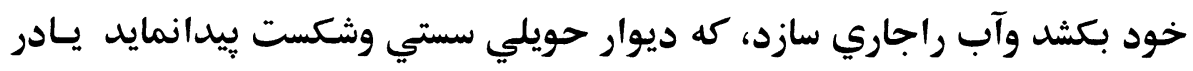

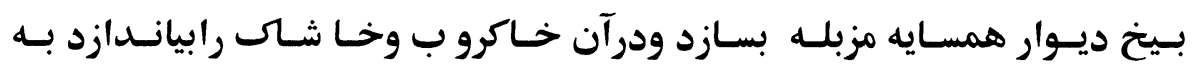

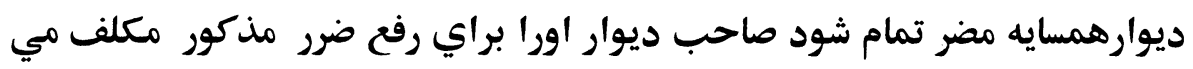

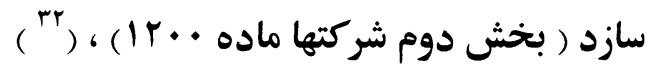

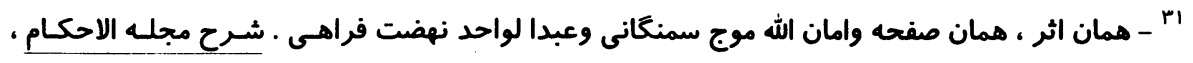

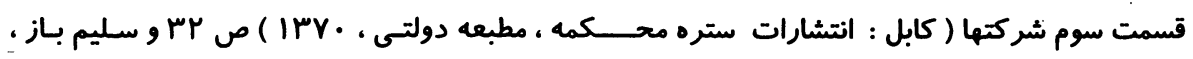

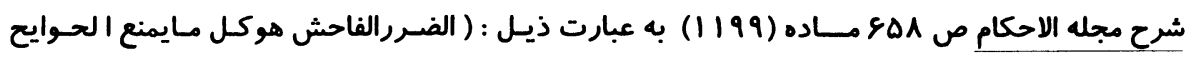

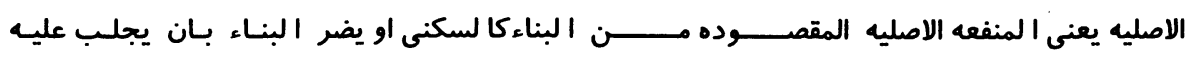
وهنا و يكون سبب انهدامه ).

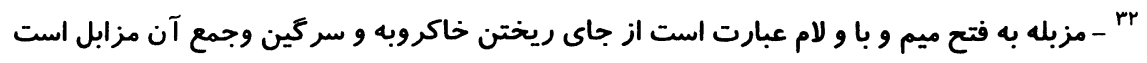

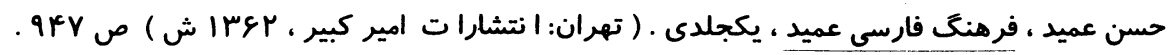
(AN) 


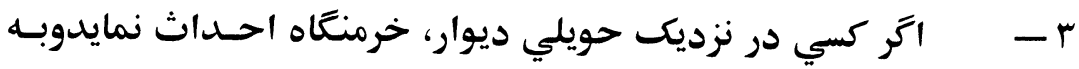

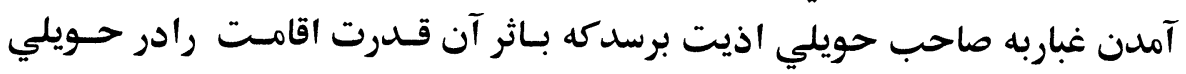

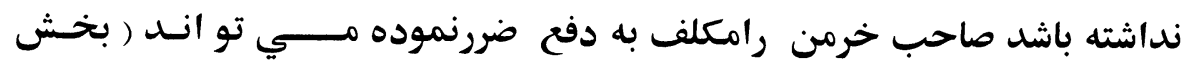

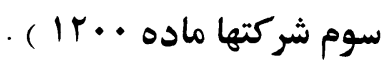

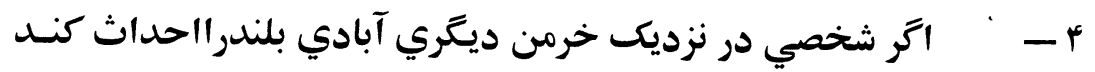
و جاي وزيدن بادرا بندنمايد ، برفع ضـرر فـاحش مكلـف سـاخته ميشـود(همــان منبc)

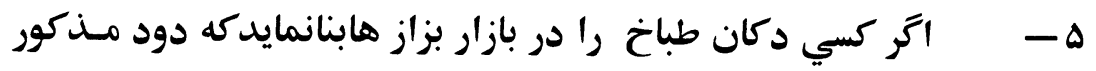
به كالاي همسايه ضرر فاحش برساند مكلف به رفع ضرر مذكور مي گردد ( همان منبع ( )

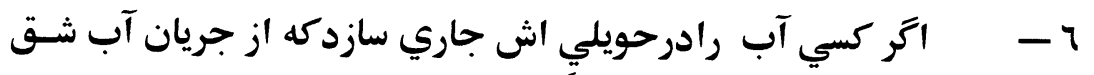

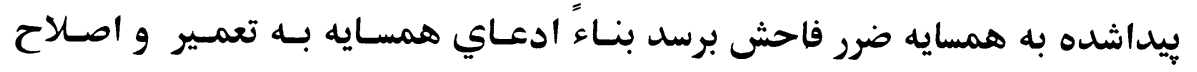
جوي مذكور لازم ميشود (

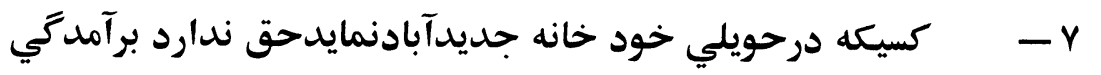

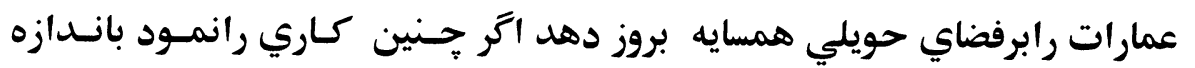

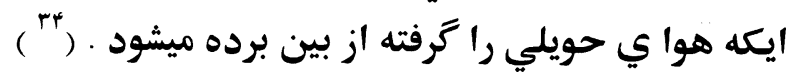

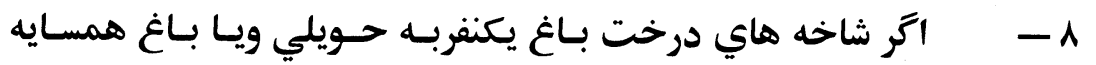

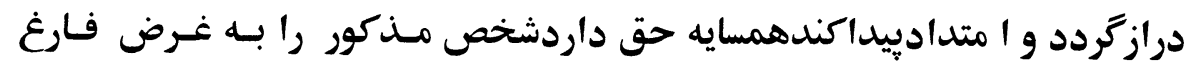

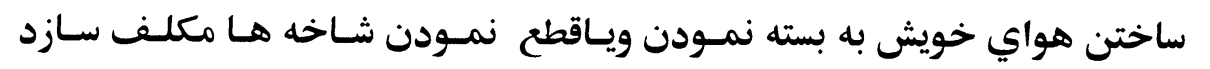

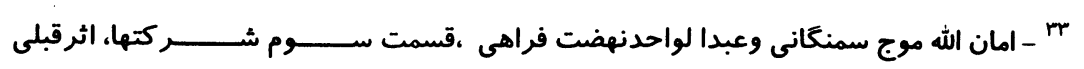
صفحات rr-. If If - هar (19 


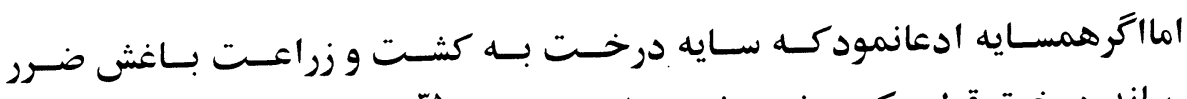

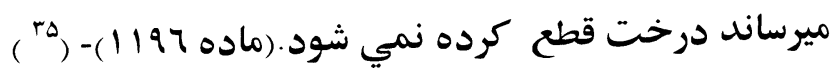

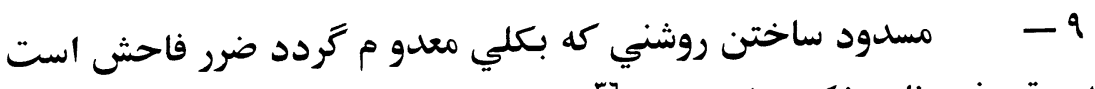

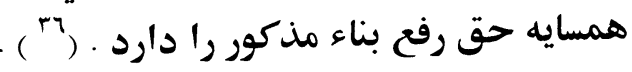

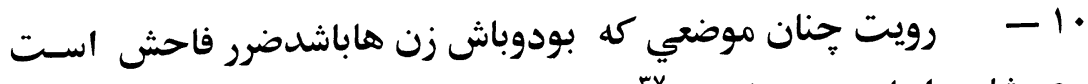

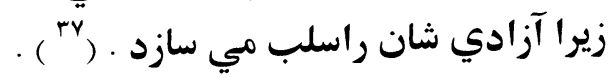

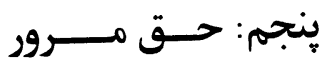

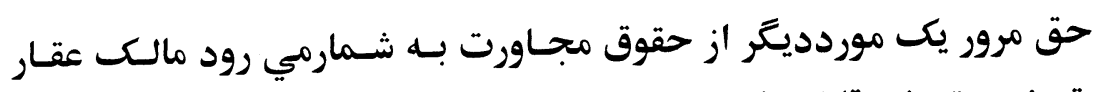

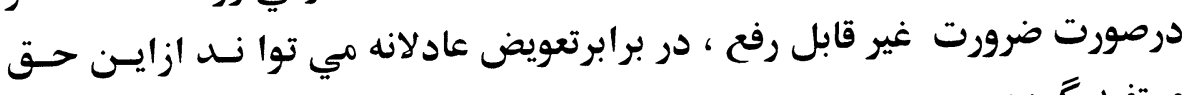
مستفيد گردد .

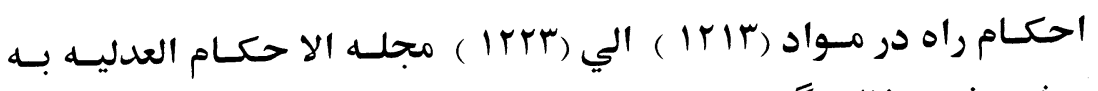

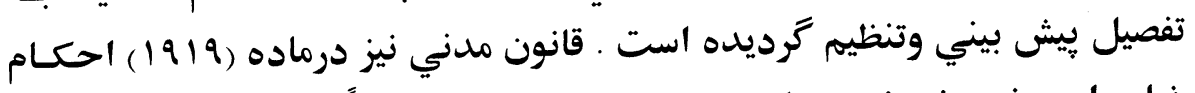

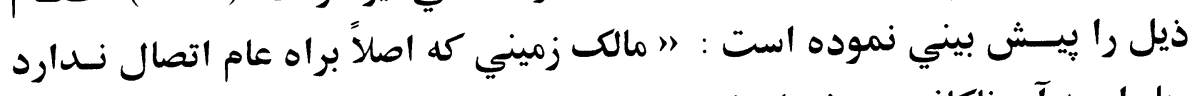

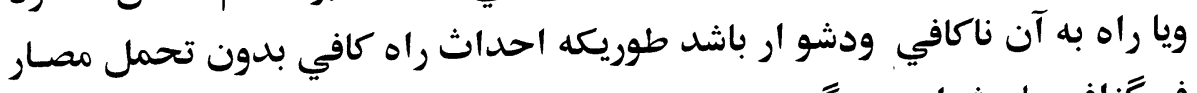

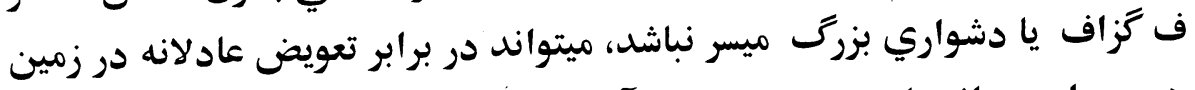

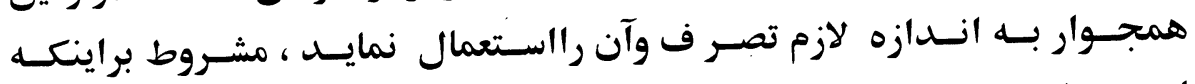

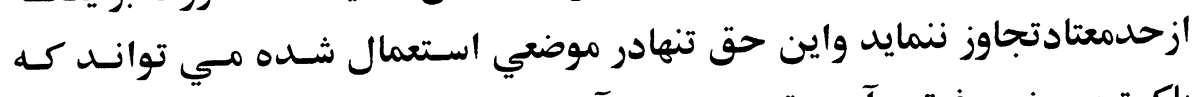

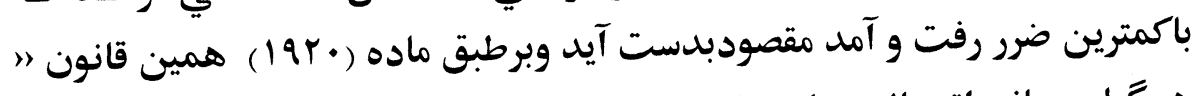

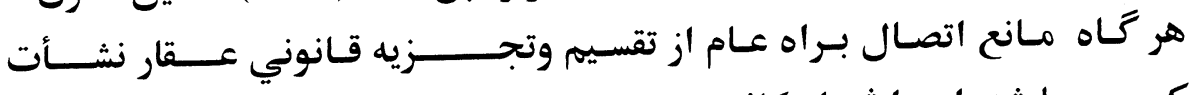

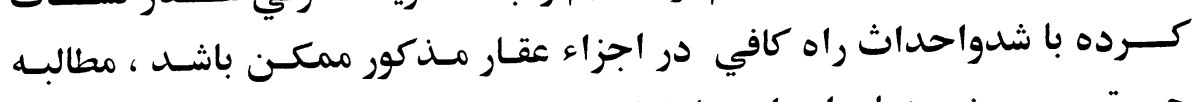
حسـق مروربجزدرهمان اجزاءجوازنداردي،

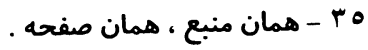

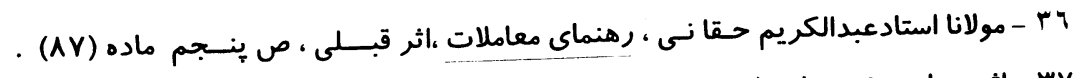

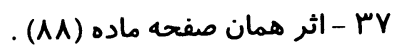




$$
\text { ششم: مـو ضــو ع آب آب دور }
$$

موضوع آب در حفظ روابط همسايكي وبقاي حــق مجـاورت نقـش عظيم

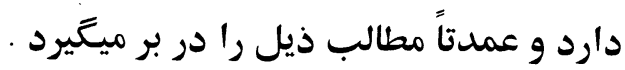

$$
\begin{aligned}
& \text { - - استفاده ازمنبع آب . }
\end{aligned}
$$

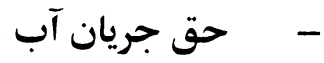

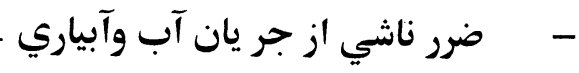

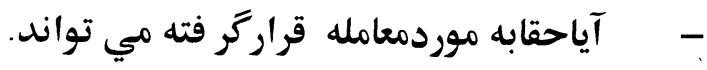

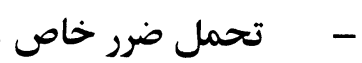

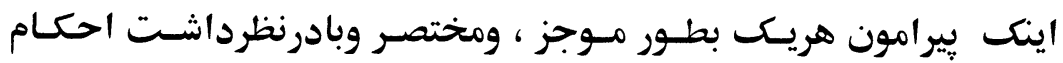

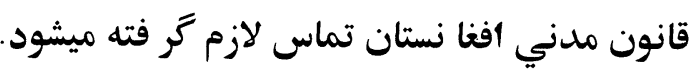

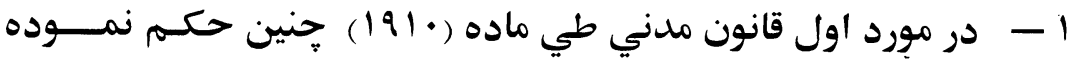

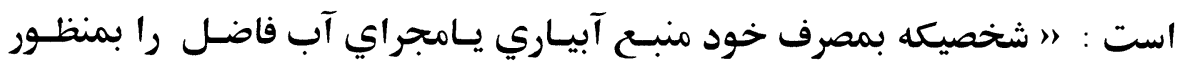

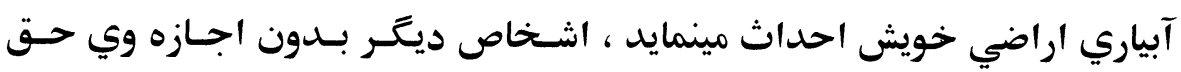

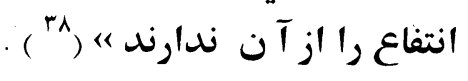

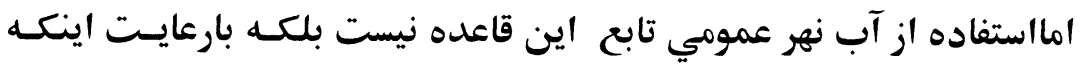

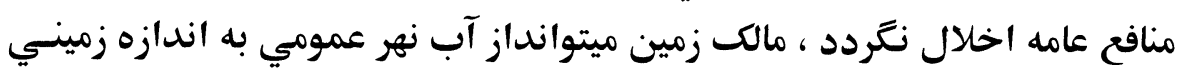

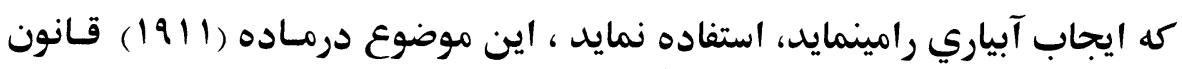

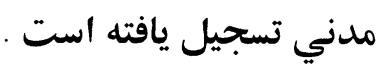

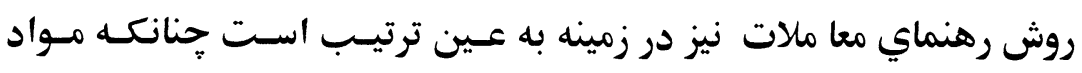

$$
\text { ذيل صراحت تام دارد }
$$

ماده باه - هركس ميتواند ازانهار عظيمه جويجه كشيده وبـزمين خـودآب

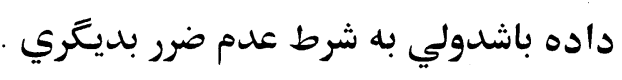

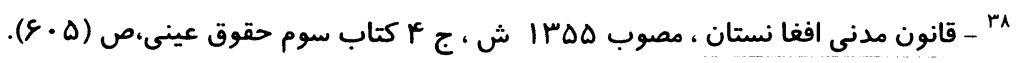

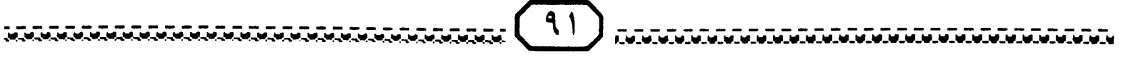


ماده هه - در ا نهار مملوكه حق شر ب براي صاحبان آن ثابت وبراي عامه حق نوشيدن آب مذكور است وبس أه

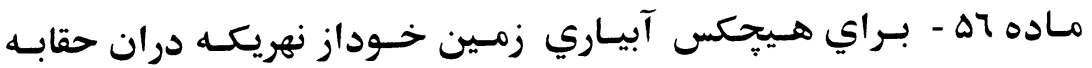

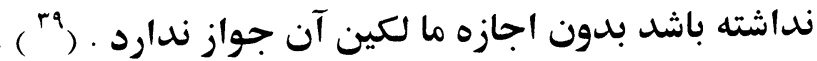

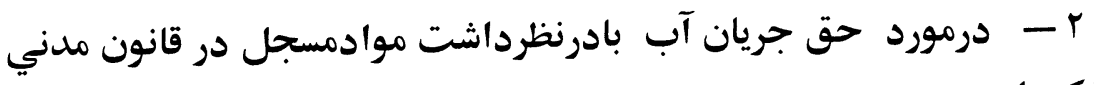

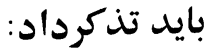
مالك اراضي ايكه بواسطه آلات بانهر زمين خـودرا آبيـاري مينمـا يــد در

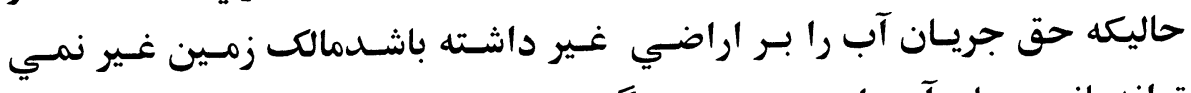

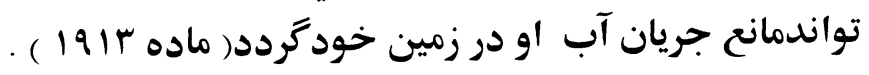

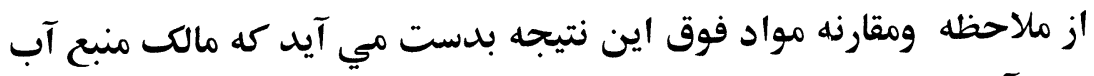

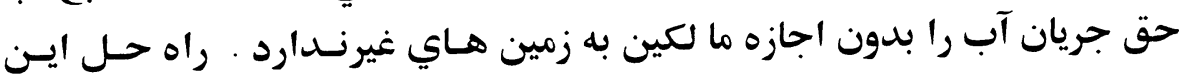

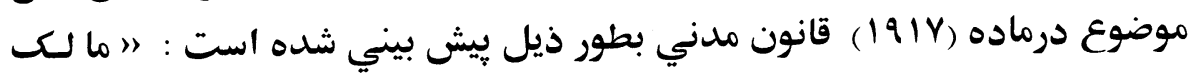

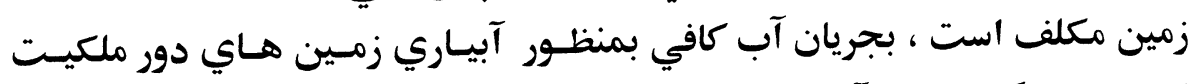

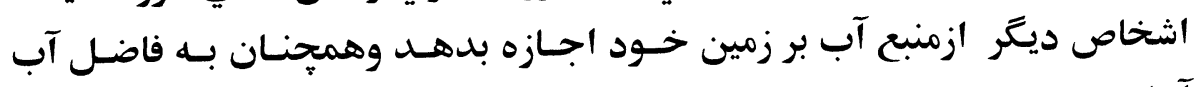

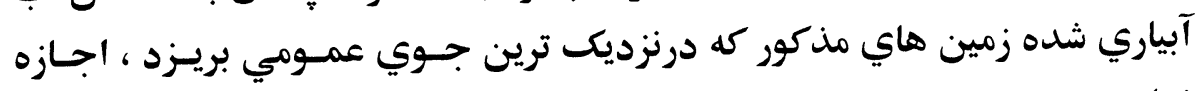

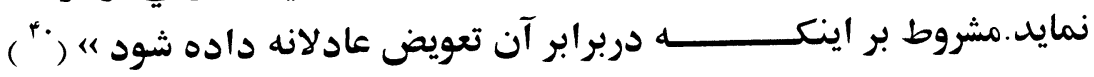
درموردضرر ناشي از جريان آبيكه بزمين مجاور عايد ميشود قـانون مـدني

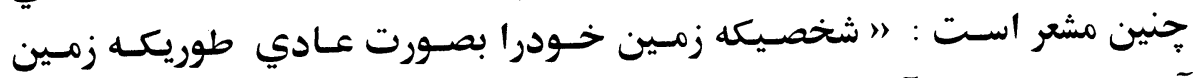

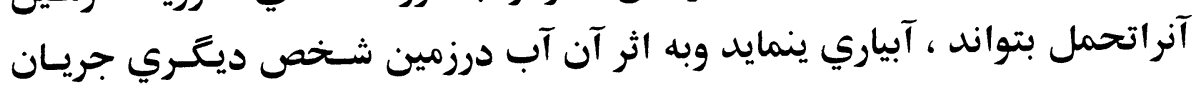

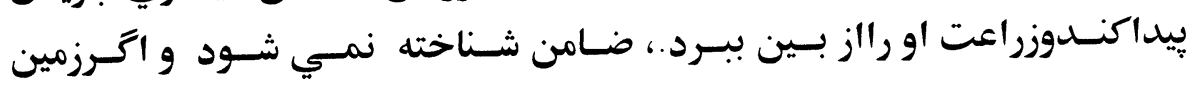

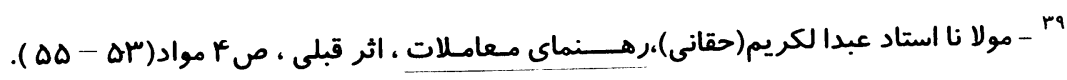

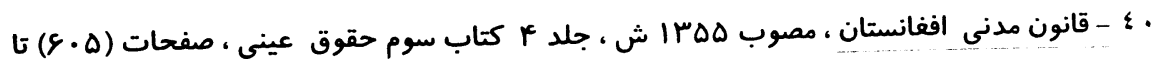
$(\varepsilon \cdot V)$ 
خودرابصورت غير عادي آبياري نمـوده وشـخص ديَــري از آن متضـرر تَردد ، ضامن شناخته ميشود " (")

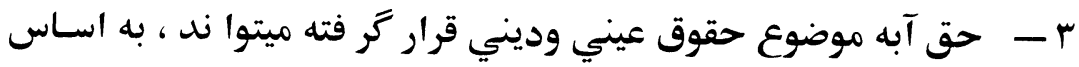

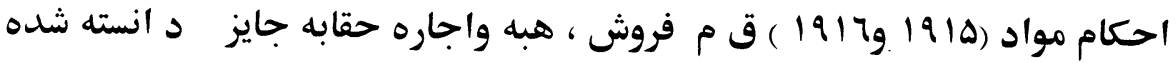
است .قيدي راكه قانون برحقابه تخاشته عبارت از تابعيت آن از زمسين اسـت كـهـ

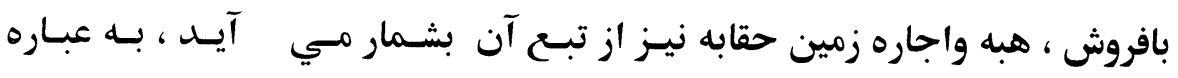

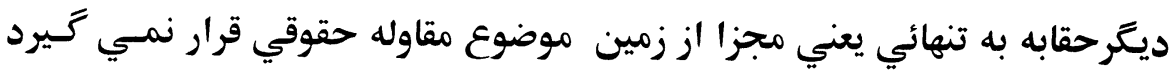

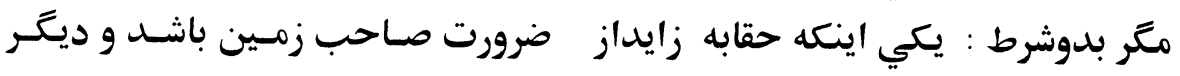

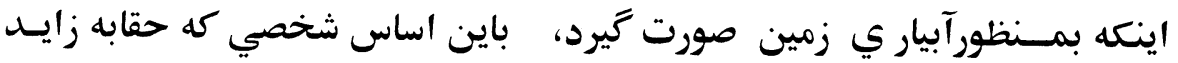

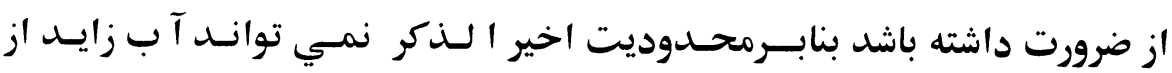

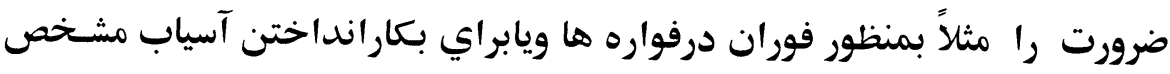

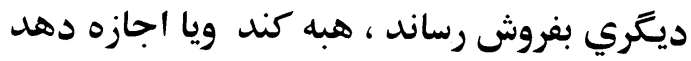

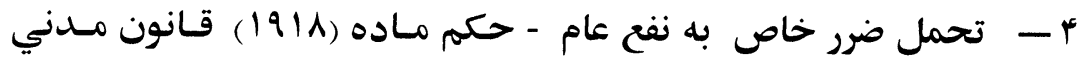
شركاي يك جوي يا نهر رابه نفع خود شان وادار به اصلاح نهر ياجوي مي سازد

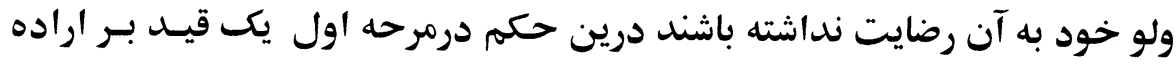

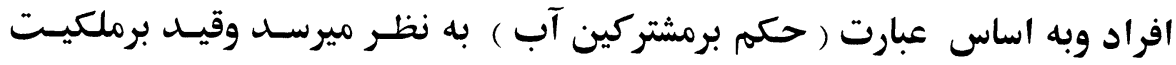
وقتي عرض وجود مي نمايدكه در اثر اجبار به اصلاحات ضروري نهر ياجوي ل

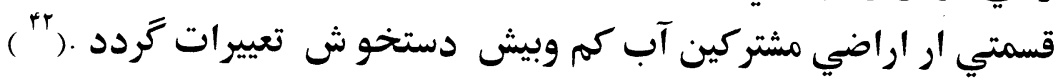
فهرست منابع ومآخذ:

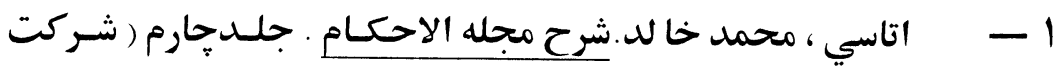

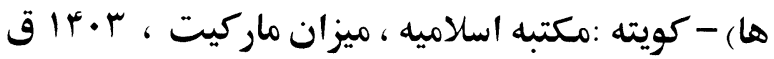

$$
\text { " - همان منبع ، صفحه (8. (8) ماده (19|F) }
$$

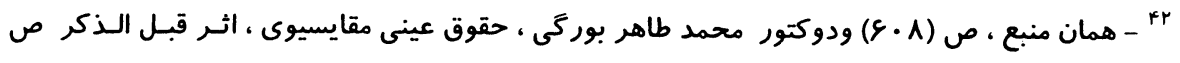




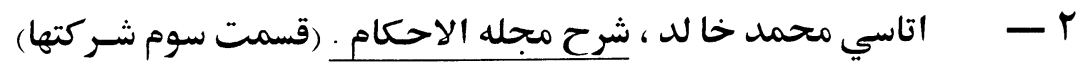

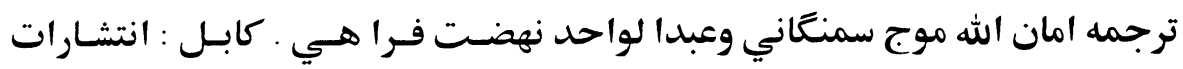

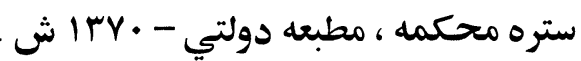

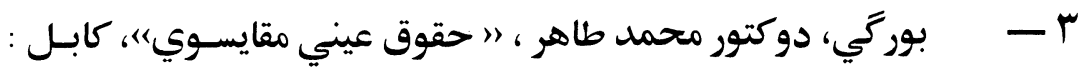
انتشارات يوهنحي حقوق پوهنتون كابل ، طبع گستتنري ، مطبعه يوهنتون .

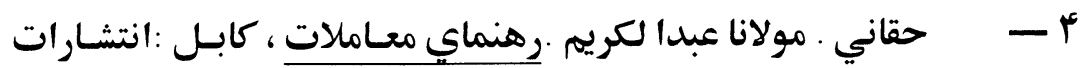

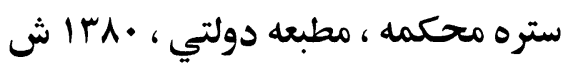

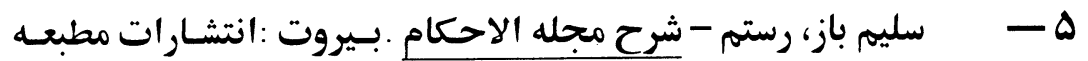

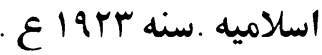

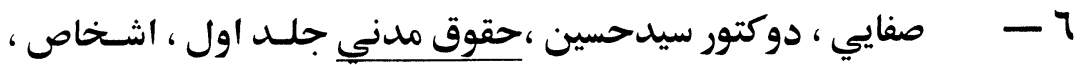

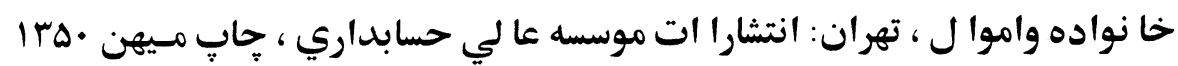

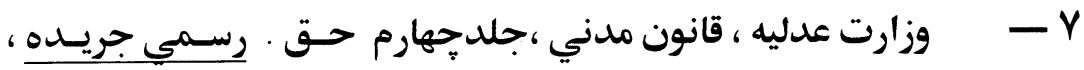

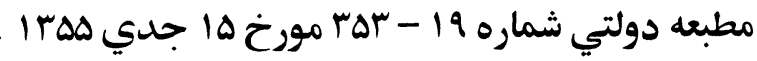




\section{تتبع و نتارش : قضامت بمه شاه علم \\ قضاوت يوه شاه علي اصغر \\ (شهرستاني ( )}

\section{حقوق بُر ورعايت آن \\ در افغانستان}

مقلفمه :

ازخلال نشرات وتبصر ه هاي مطبوعات بين المللي برمي آيد كه در موردرعايت

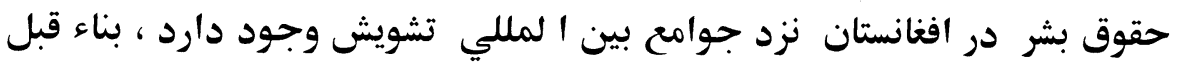

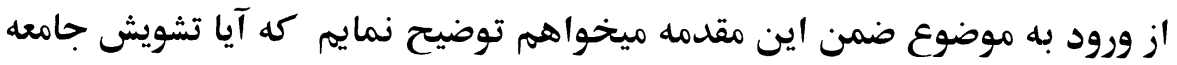

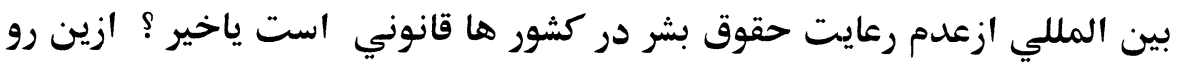

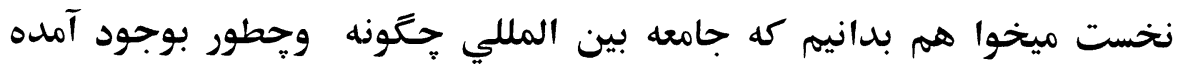

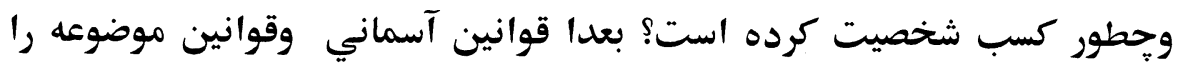

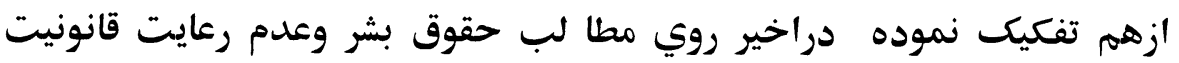
ونقض حقوق بشر و روي مسايل مر تبط به آن تاجائيكه به اين مضمون رابطه مي گيرد تماس خواهيم گرفت بخش اول : بوجود آمدن جامعه بين المللي وكسب شخصيت كرفيت آن

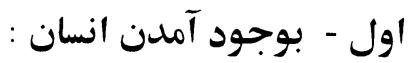

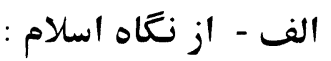

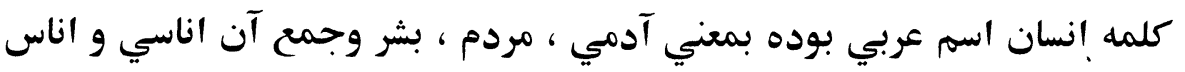

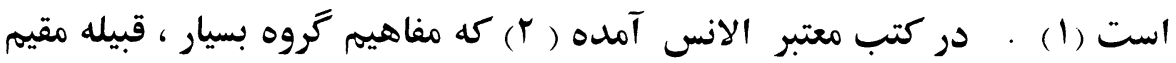
بجائي را در بر دارد . در ديكشنري هاي انتًيسي به فارسي وعكس آن 
- person

كلــمات انسان ، آدم ، بشر ، شخص ، فرد بنام هاي

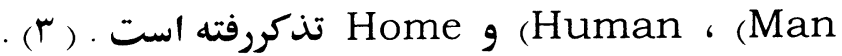

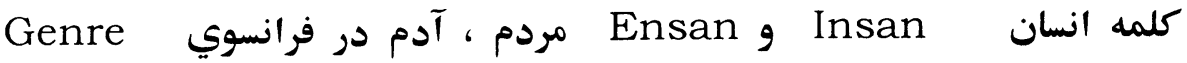

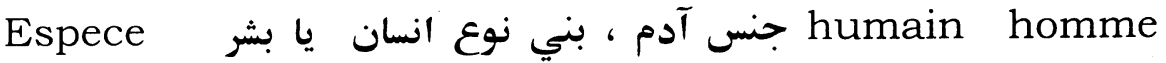

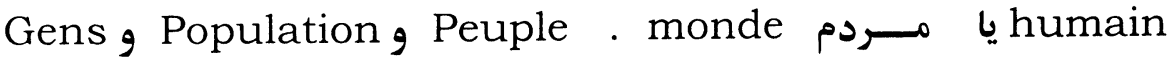
آمده است وهمين قسم در ساير زبانهاي دنياكلمات آن زياد است .

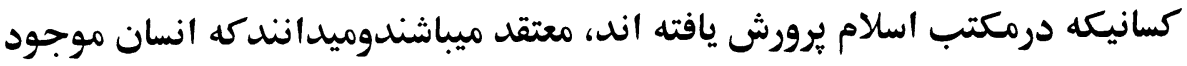
ي است كه خداوند (ج)آن را خلق كرده واولين وحي الهي در قرآن به سوره ا

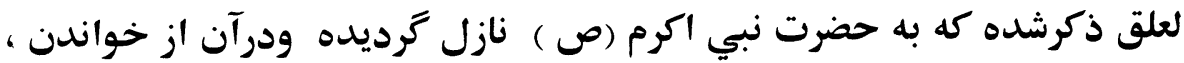

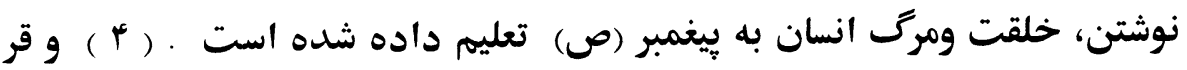

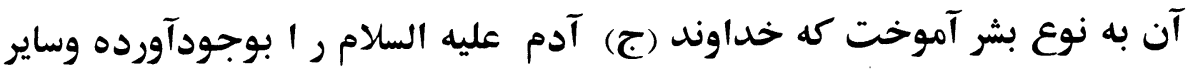

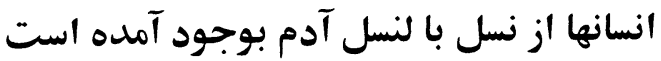

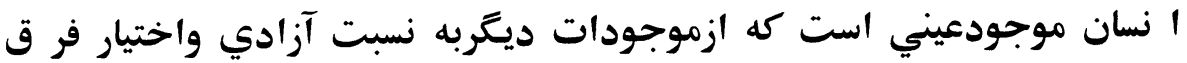

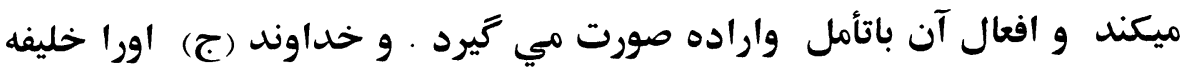

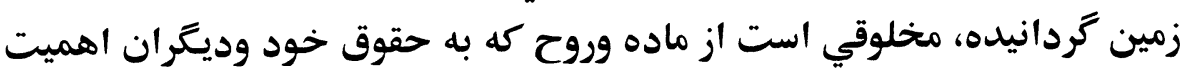
(ه) (هايل است ب : : از نغاه انسان شناسي : اين مطلب بنام) Anthropology) يابشر شناسي آمده ، بشر شناسان ادعامينمايندكه انسان رامطالعه مينمايند ، اختلافات شان در آن است كه هركدام

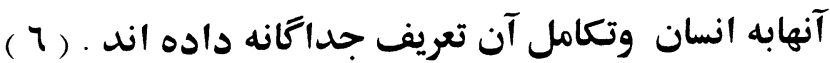
علماي اقتصاد، فلاسفه وبشر شناسان هريك تعاريفي از انسان نموده اند ، مكر اندران

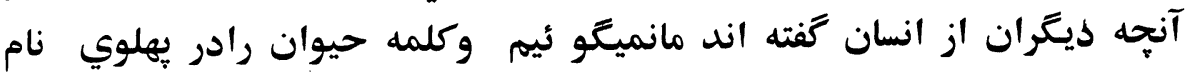

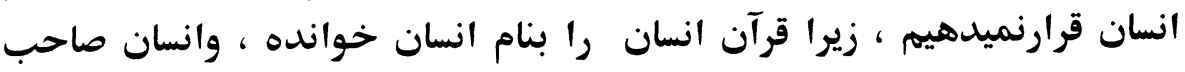

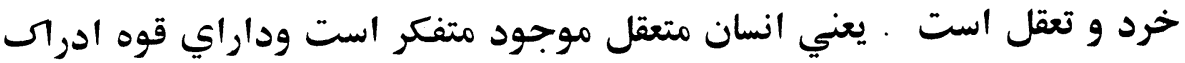


وموجود داراي ثقافت و فرهنَ بوده ، مفاهمه ومراوده مينمايد كه حيوا نات

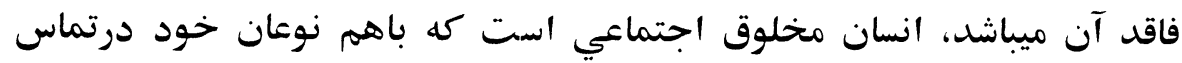

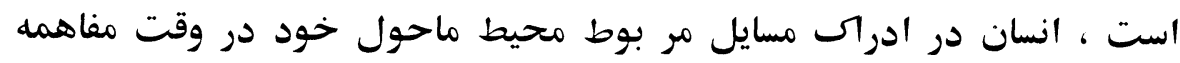

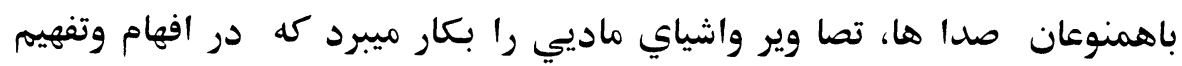

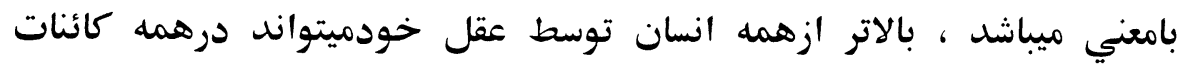

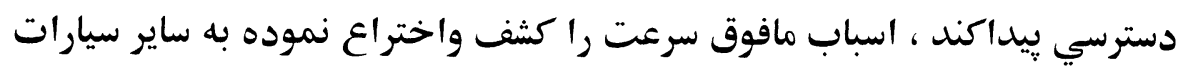

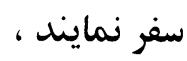

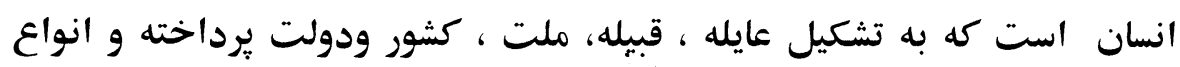

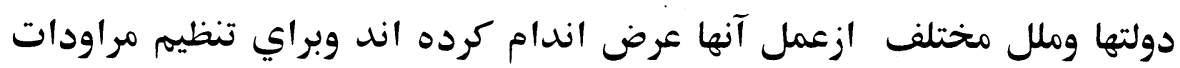

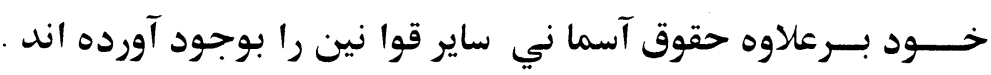

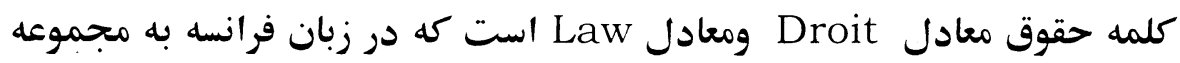

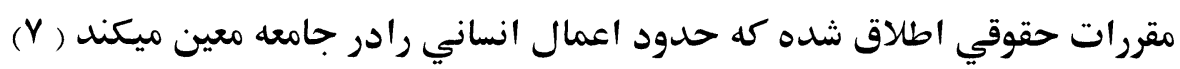

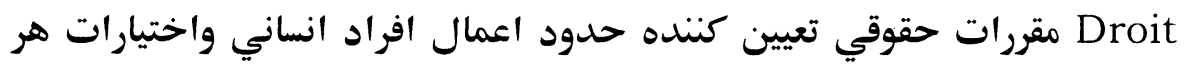

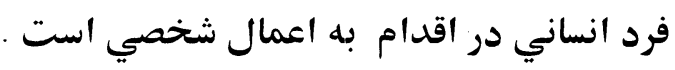

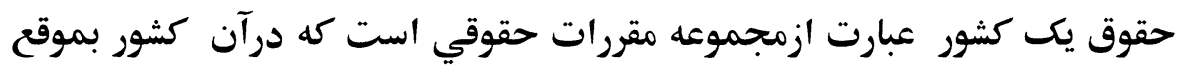

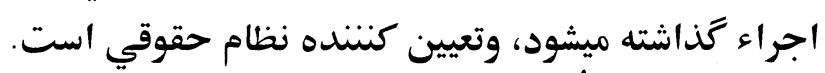

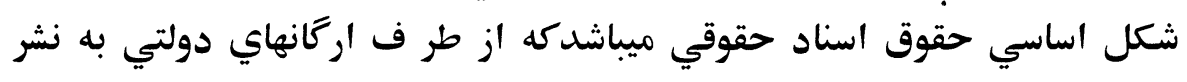

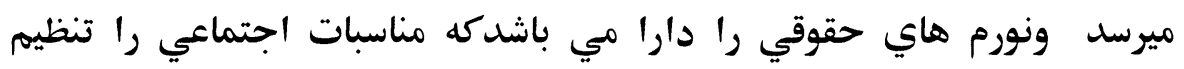
ميكند.

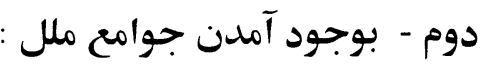

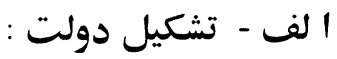

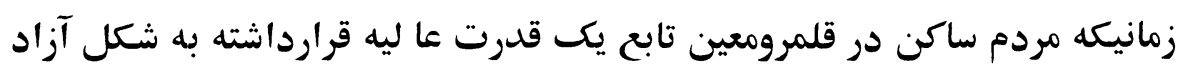

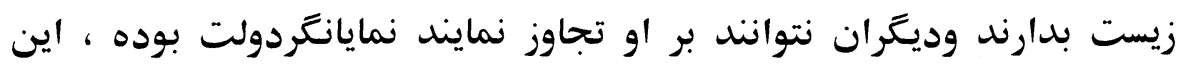

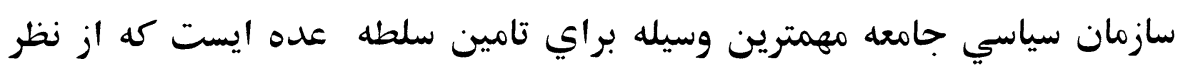


تشكيلات در جامعه نقش حاكم دارد ، ووظيفه اساسي آن حفظ و تحكيم نظام

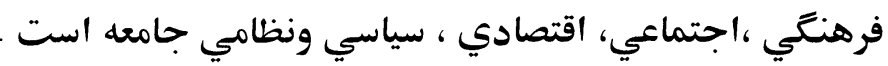

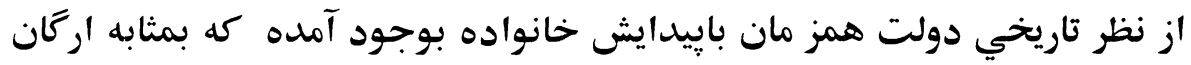

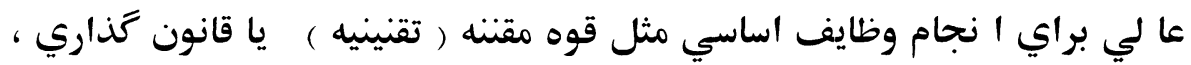

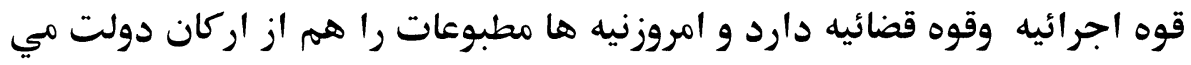
شمارند ب - تشكيل سايردول ياجامعه ملل :

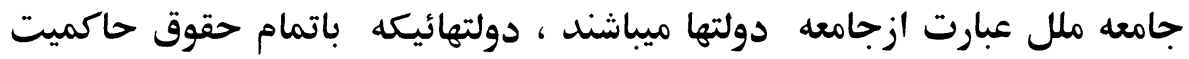

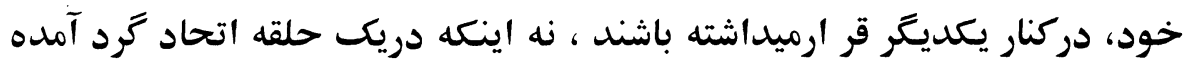

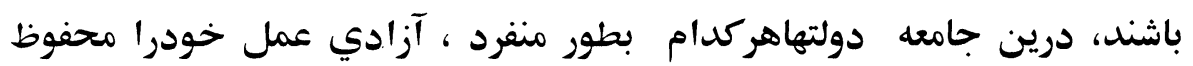

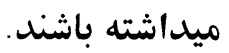
سياستمداران مجامع جامعه ملل هركدام بانيت خاص بمنظور تحصيل هرجه

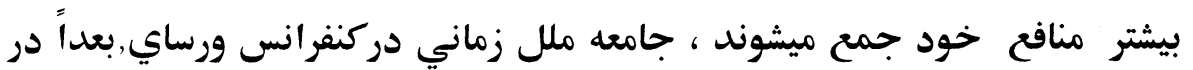

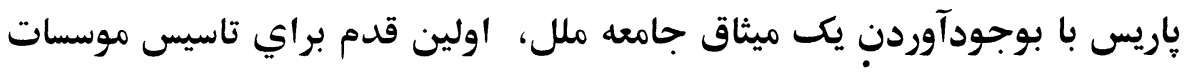

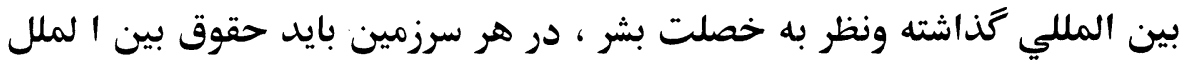

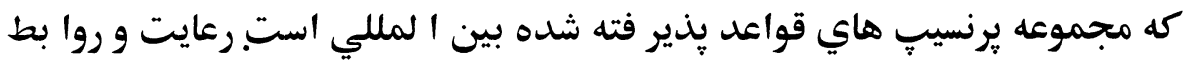

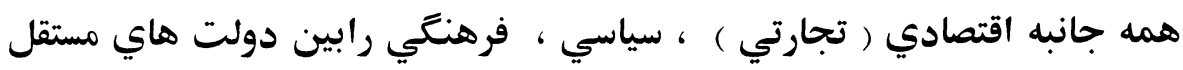

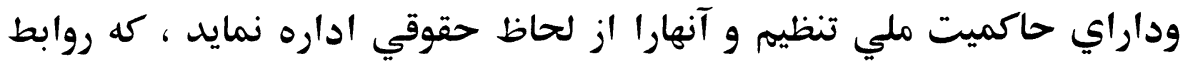

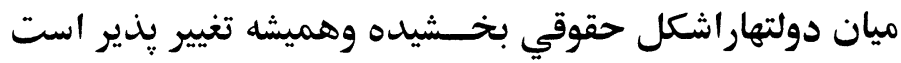

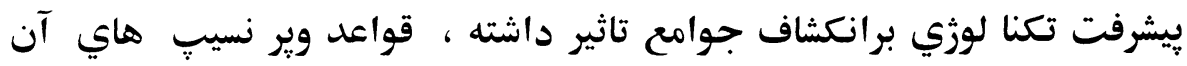

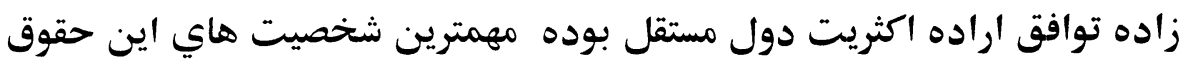
رادولت هاي مستقل تشكيل ميدهند.

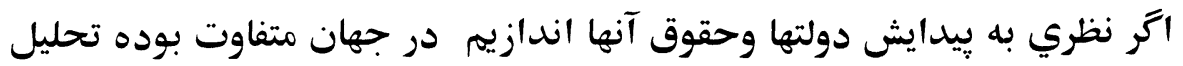

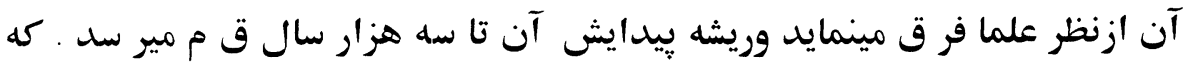


مامعاهدات popis ها، آتن واسيارت در هزار ه ق م را كه مثل روم باكار تاز

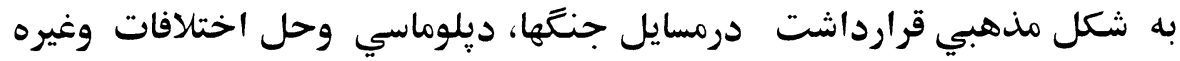

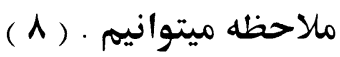

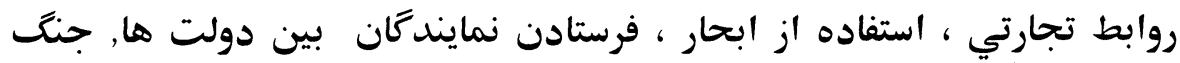

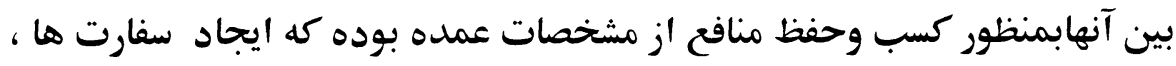

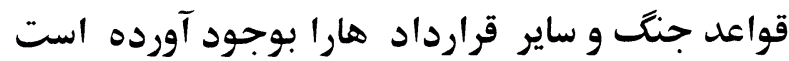

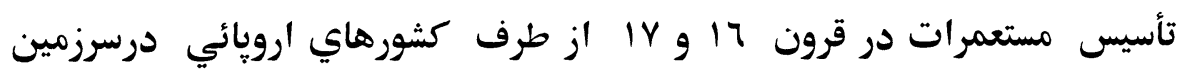

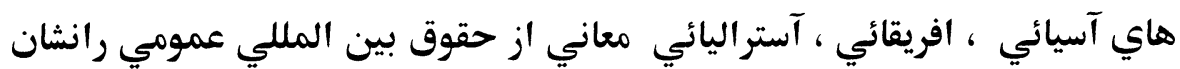

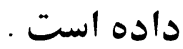

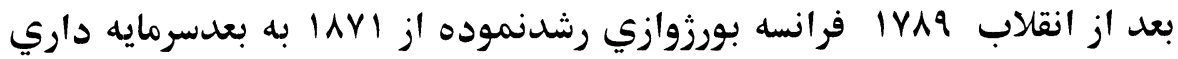

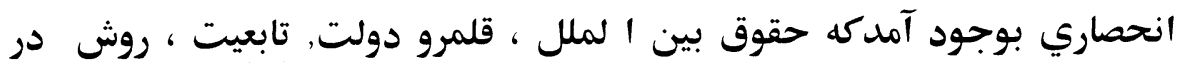

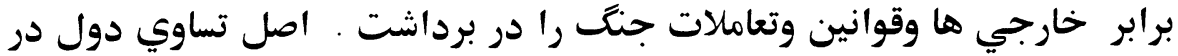
حقوق بين الملل درجوامع عدم مداخله درامورداخلي دول دئيكر نيز درحقوق

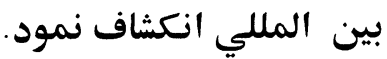

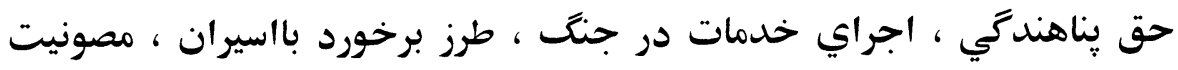

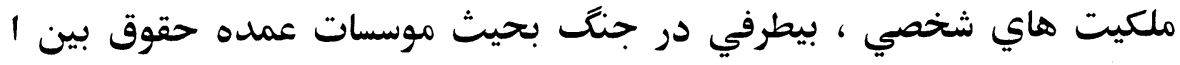

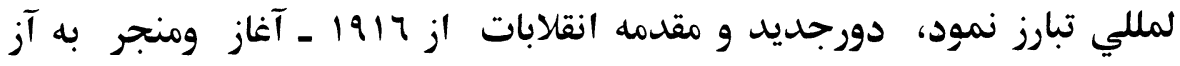

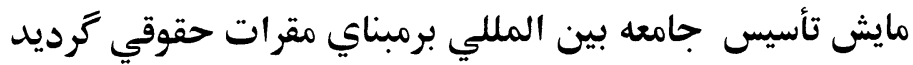

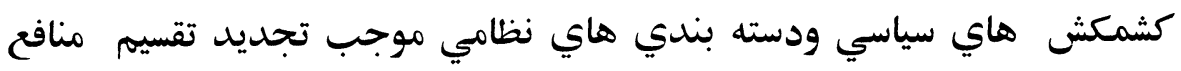

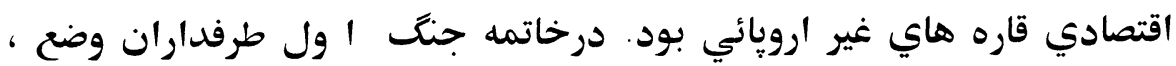

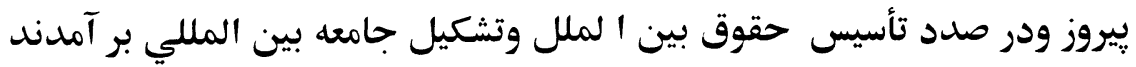

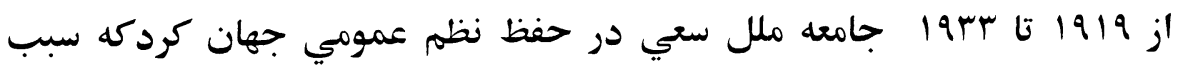

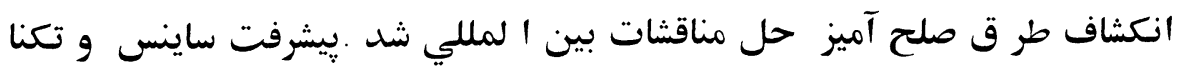

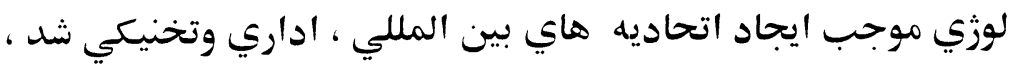


بعد از آر ا انقلا بات جديد شروع ترديد ، حق تعيين سرنوشت ملل بدست

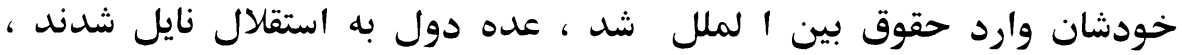

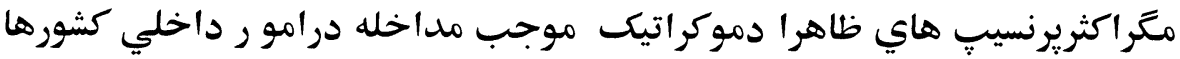

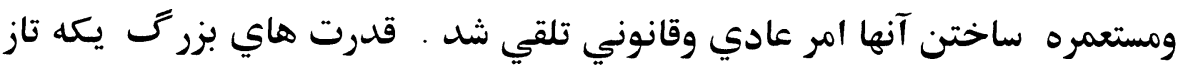
جامعه بين الملل بودند.

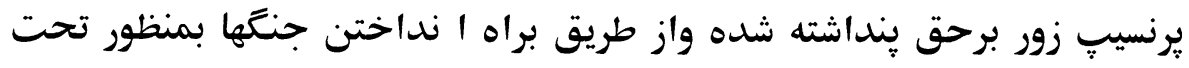

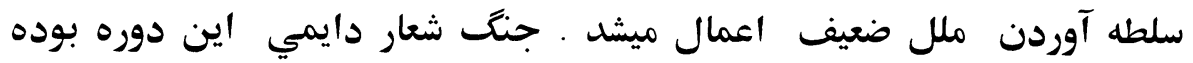

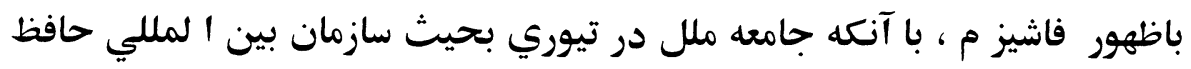

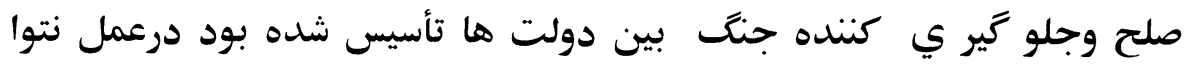

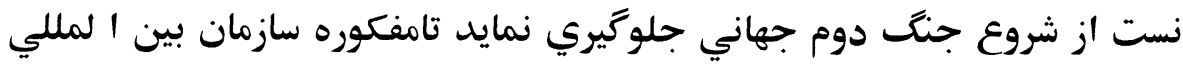

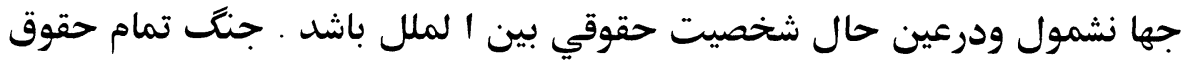

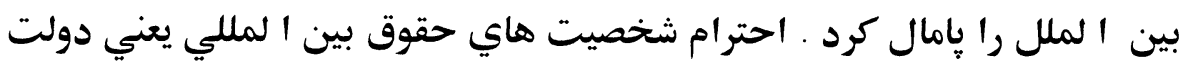

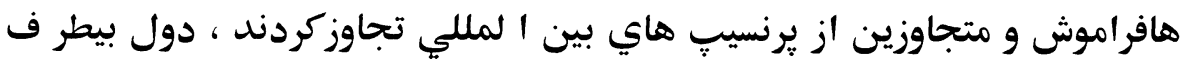

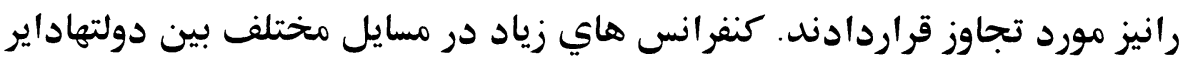

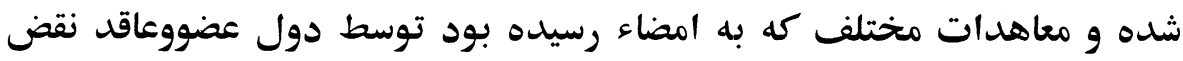

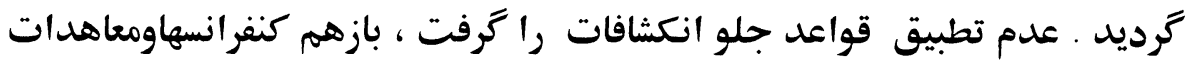

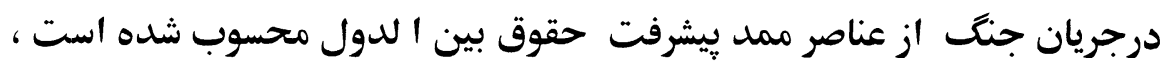

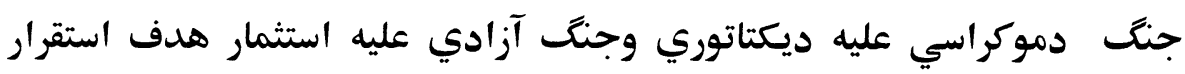

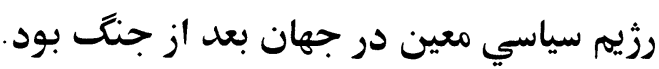

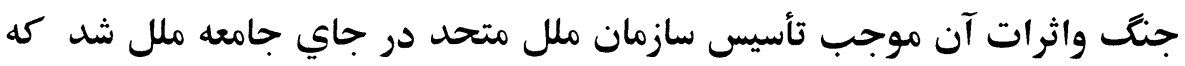

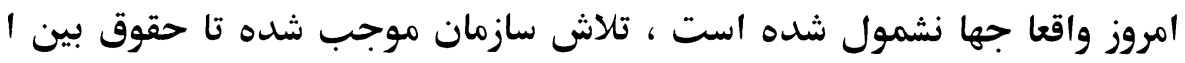

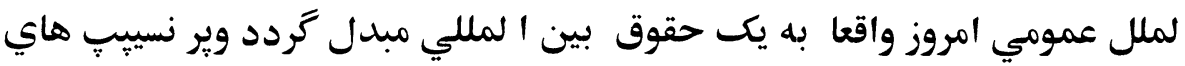

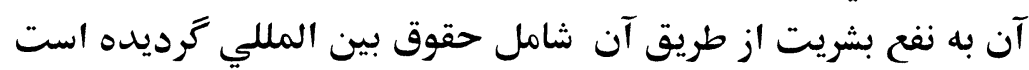




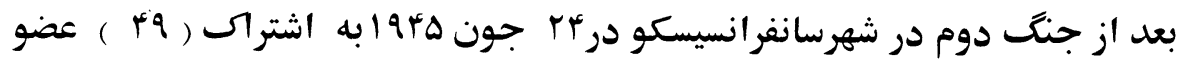

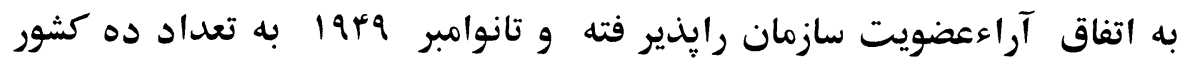

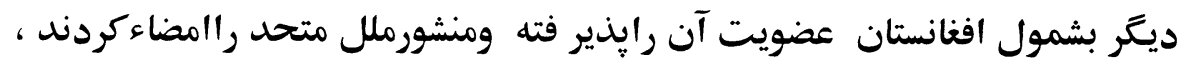

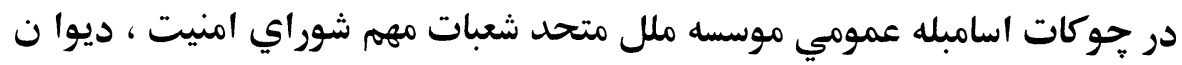

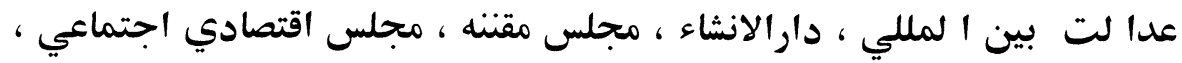

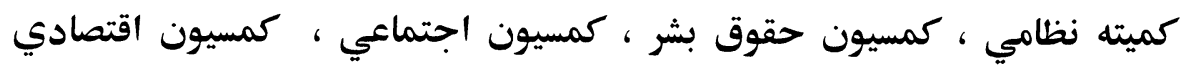

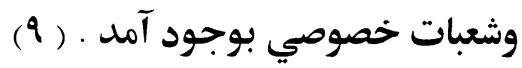
بعد از جنگ شخصيت هاي حقوق بين المللي افزايش يافته ممالك مستعمره

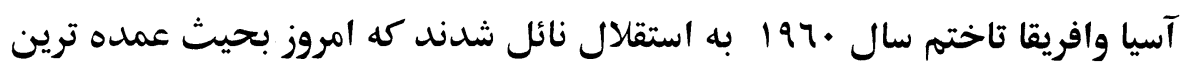
اصل حقوق با از هم ياشيدن سيستم استعماري بين المللي زمينه تحقق يافت وجنب هاي رهايي بخش ملي حيثيت شخصيت حقوق بين المللي راني در در كنار

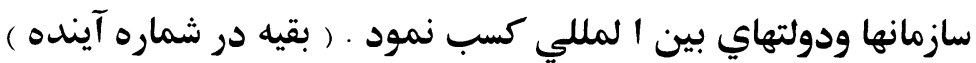

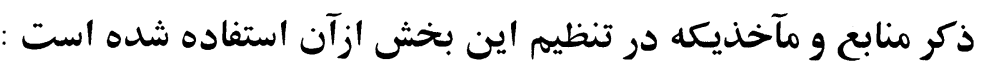

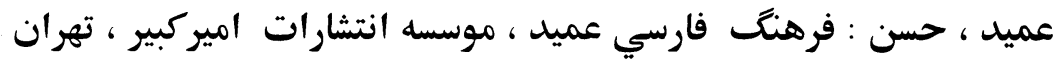
ITYD r. سياح - احمد، مولف ومترجم فر هـنتَ دانشعاهي ( عربي به فارسي ) انتشارات اسلام، تهران Iryr

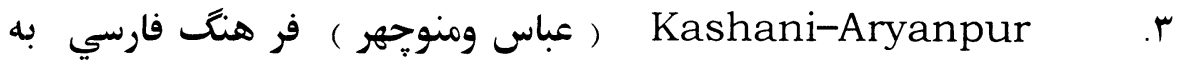

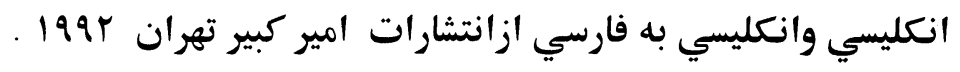

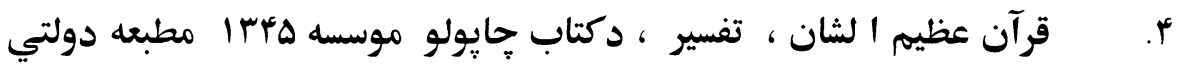

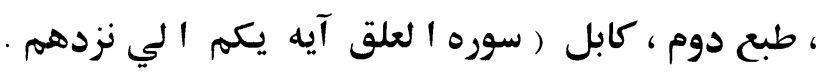

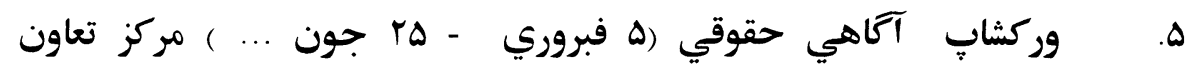
افغانستان CCA صفحات هفتم وهشتم ، پشاور، پاكستان . 
T. حدران ، يو هاند داكتر الفشاه ، ... بشرشناسي دوجلد از انتشارات

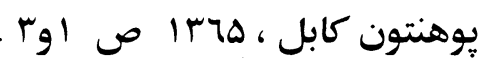

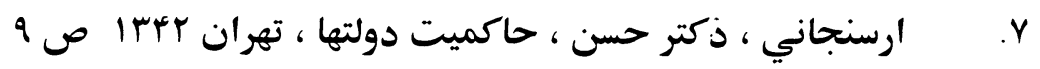

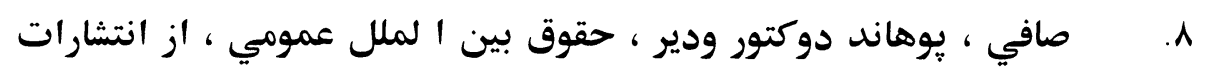

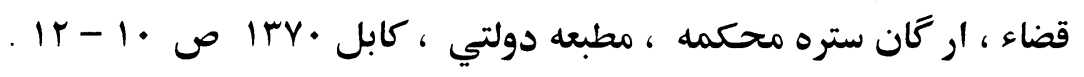

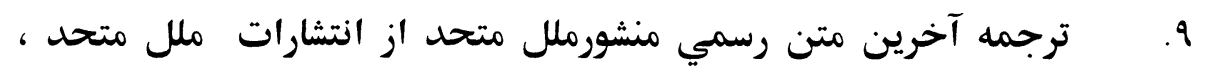
كابل . 


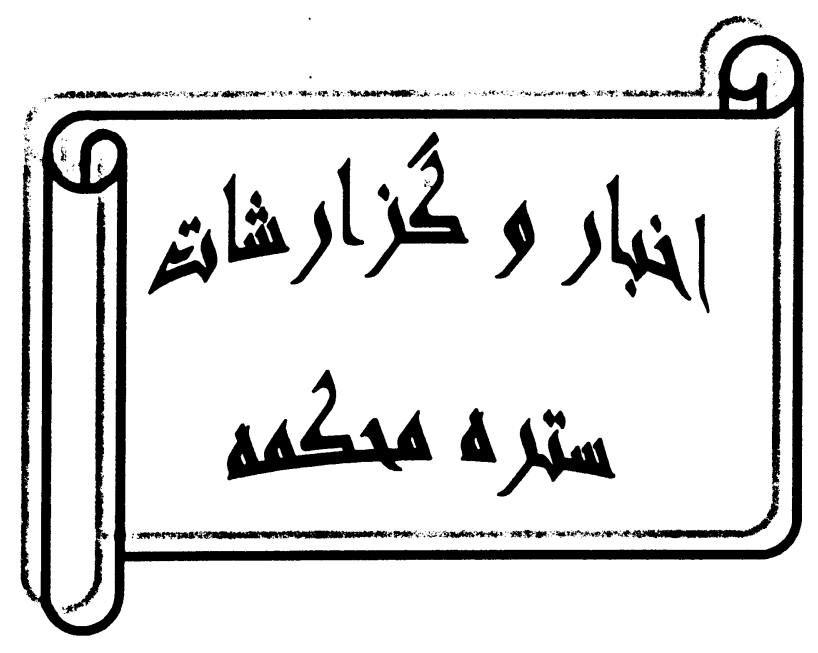

\section{ملاقات با معاون نيرو هاي آيساف}

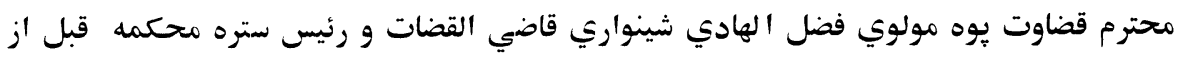

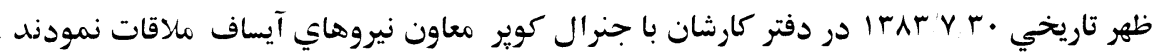

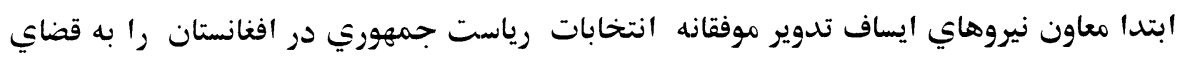

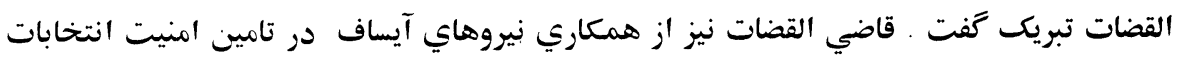
تشكر كرد القضات تير در اين ملاقات روي مشككلات قوه قضائيه و لزوم ايجاد تغييرات در آن و انتخابات بارلماني در

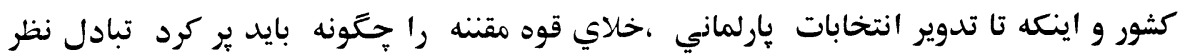

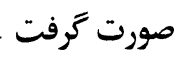
مواد مخدر و راههاي عملي مبارزه با آن از جمله مسايل ديعري بود كه در اين ملاقات مطرح

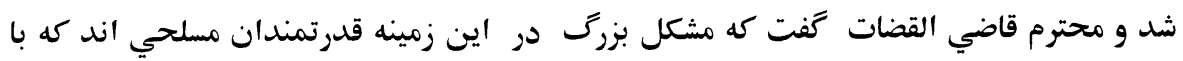
مافياي مواد مخدر دست دارند فاضي القدات

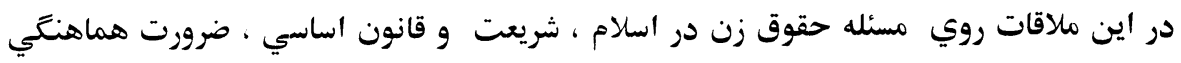

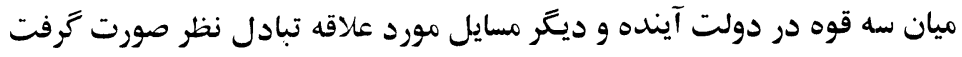




\section{ملاقات سفير كبير عربستان سعودي \\ با محترم قاضي القضات}

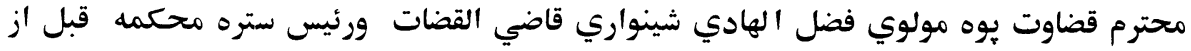

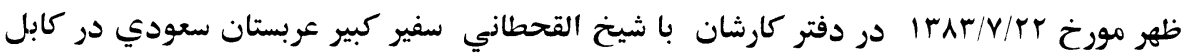
ملاقات نمودند

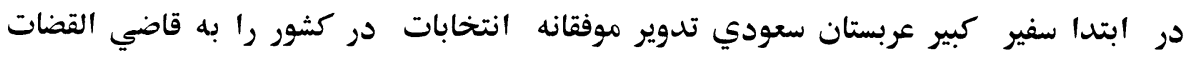

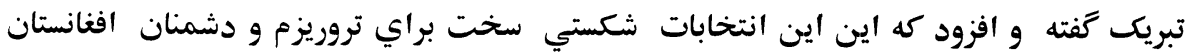

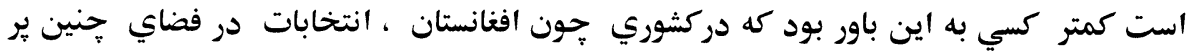

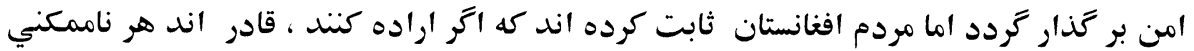
را ممكن سازند

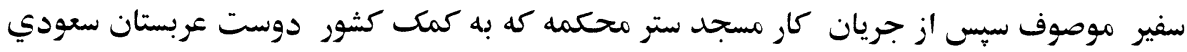

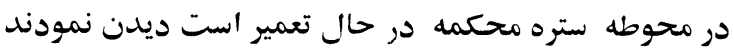

\section{ملاقات با هماهنت كنت كمك هاي كشور ايتاليادر بخش قضائي}

محترم قاضي القضات و رئيس ستره محكمه قبل از ظهر تاريخي

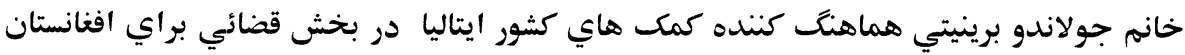
ماقاقت نمودند خانم برينتي در آغاز تدوير موفقانه انتخابات را تبريك تفت و ابراز اميد واري نمود كه انتخابات

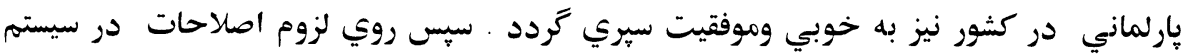

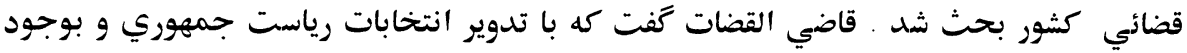

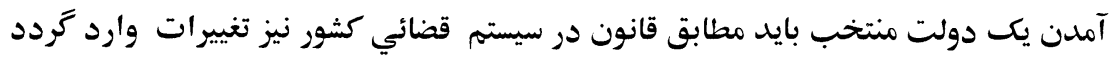

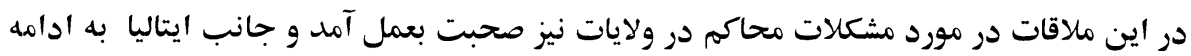

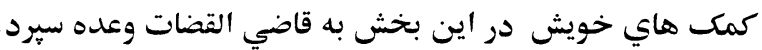

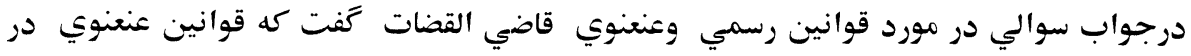
كشور ما بشرط تطابق آن با شريعت و قوانين نافذ كثور مدار اعتبار است مثلا جركه هاي كاي

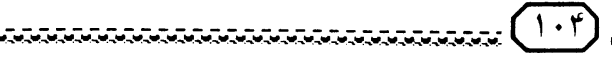

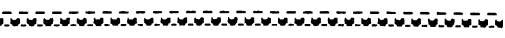


اصلاحي كه ميان دو نفر يا دو قوم اصلاح مي نمايد كه در اين صورت فيصله آن مورد تائيد

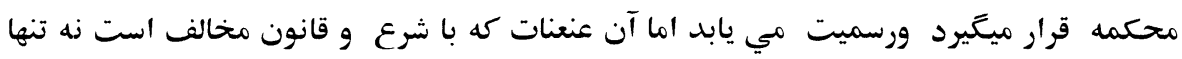

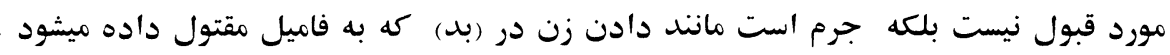

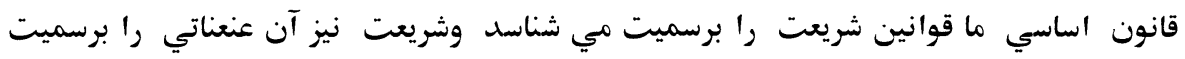

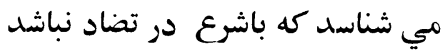

\section{جلسه قضائي \\ سه تن اختطاف كنتد اطفال}

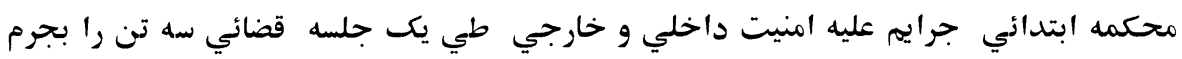

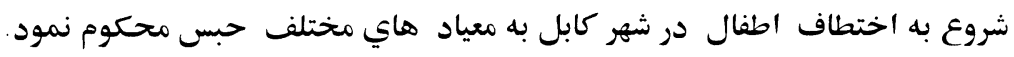

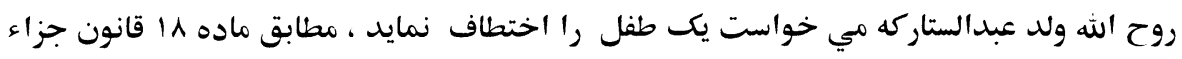

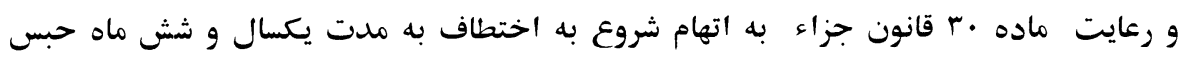
محكوم ترديد ترديدند.

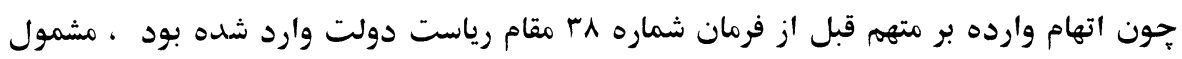
حكم اين فرمان نشد.

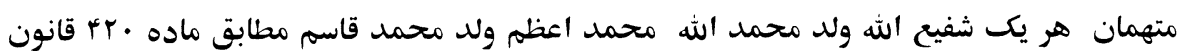

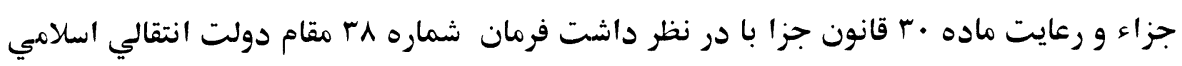

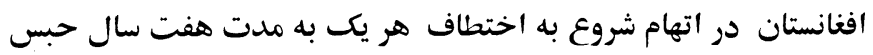

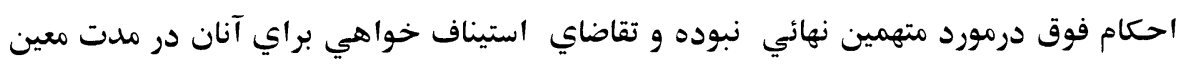
محفوظ است احكام فوق در

\section{دو نفر به جرم توزيع يول جعلي محكوم به حس زرديدند}

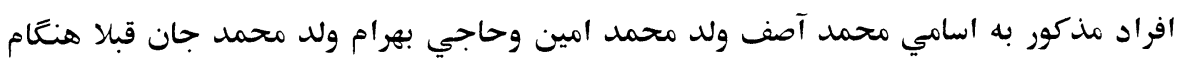

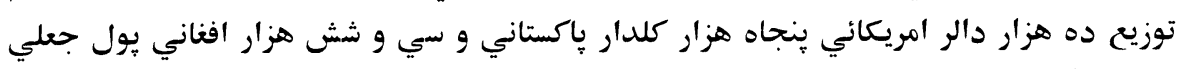

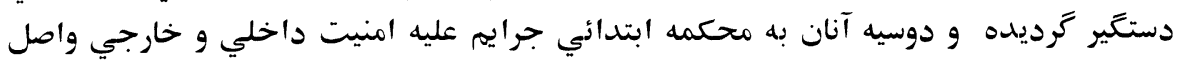
شده بود 




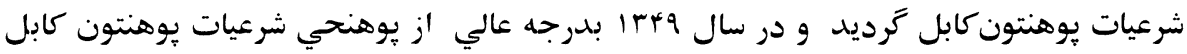

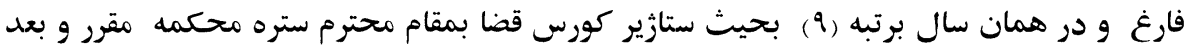

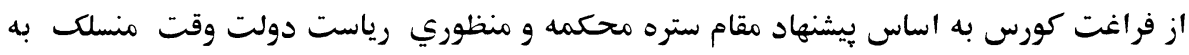

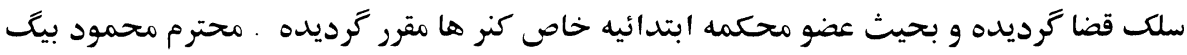

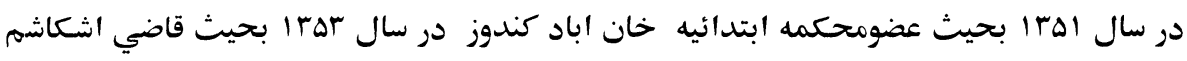
بدخشان - جرم بدخشان

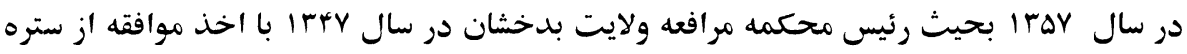

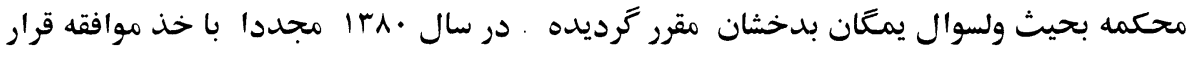

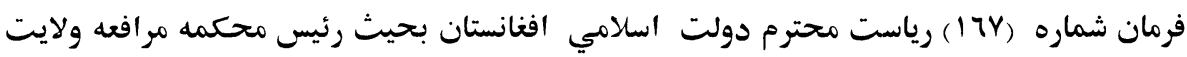

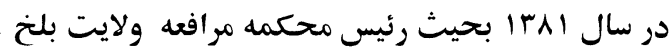

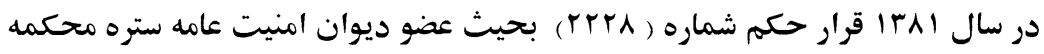

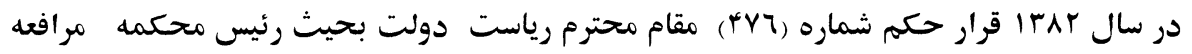
ولايت تخار

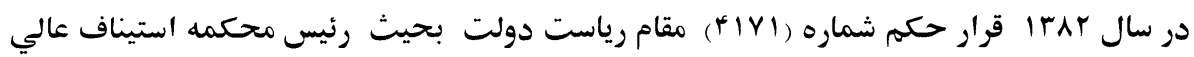
مركز

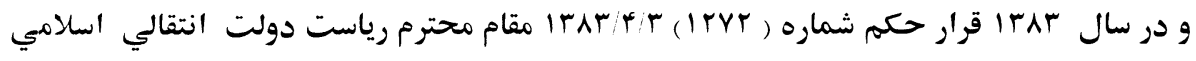

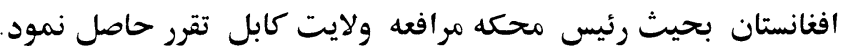

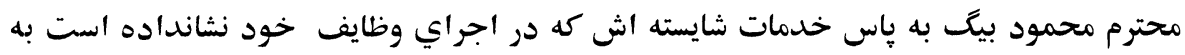

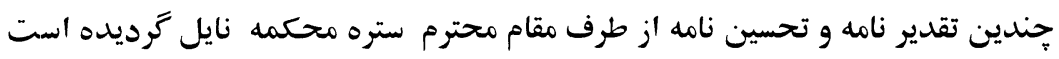

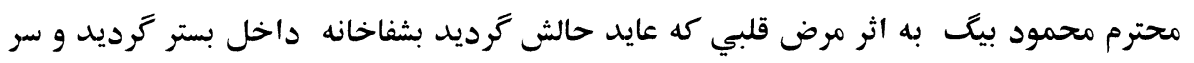

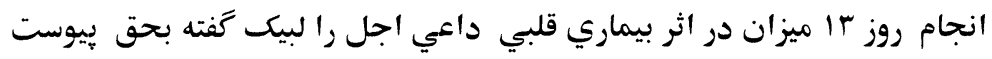

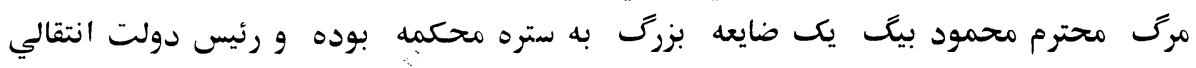

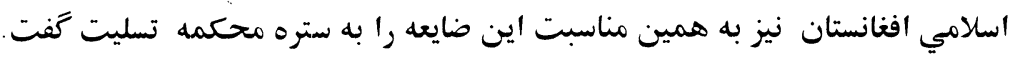




\section{سوانح مختصر مرحوم مولوي

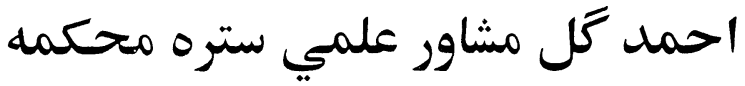

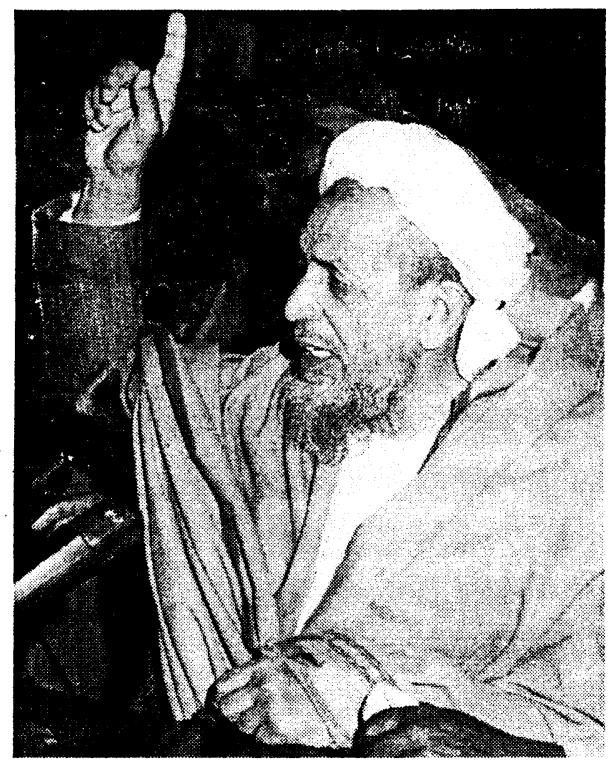

مولوي احمد گل فرزند مولانا عبيداشه در اوائسل

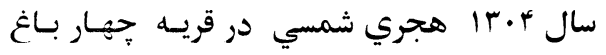

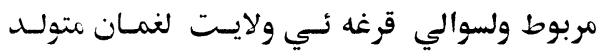

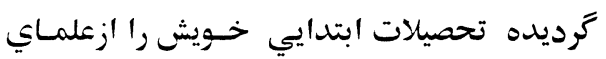

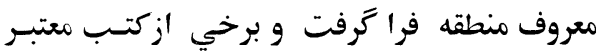

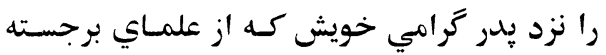

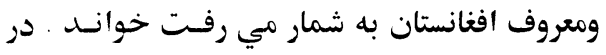

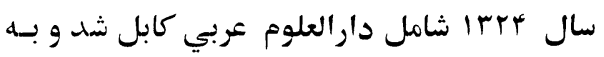

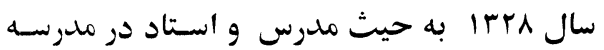

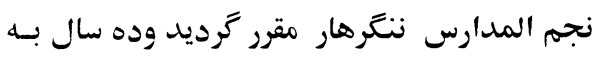

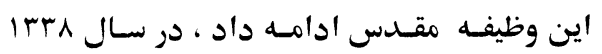

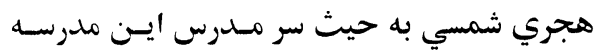

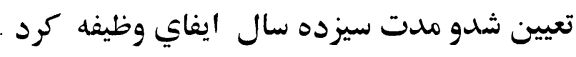

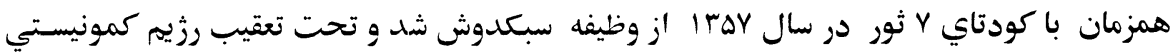

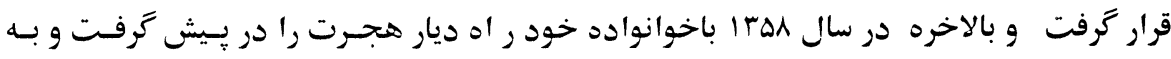

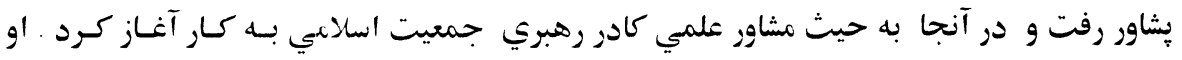

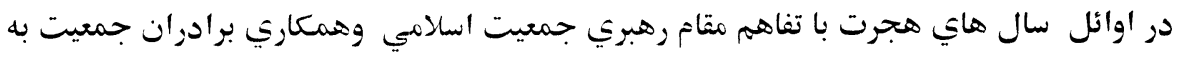

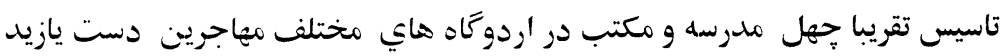

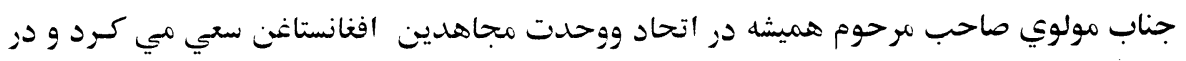

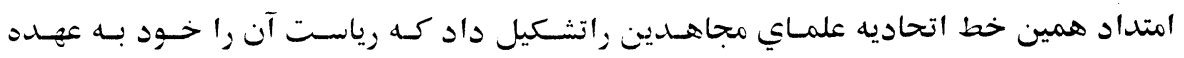
داشت.

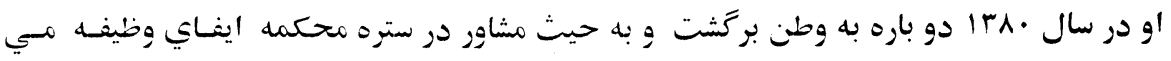

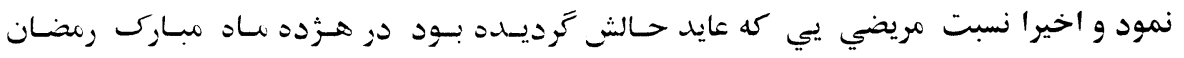

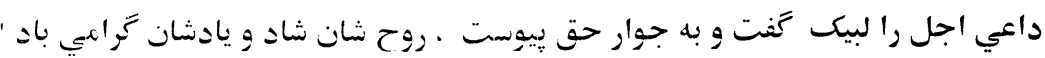

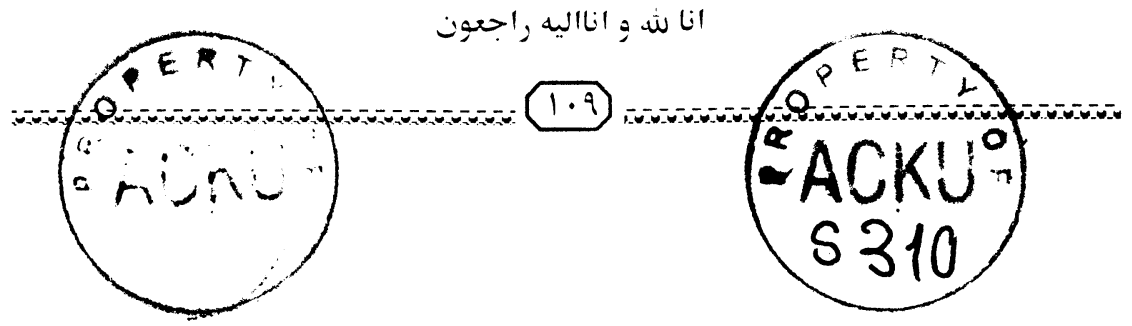




\section{د امتياز خاوند : ستره محكمه \\ ( د ليك هيئات ) تر نظر لاندي}

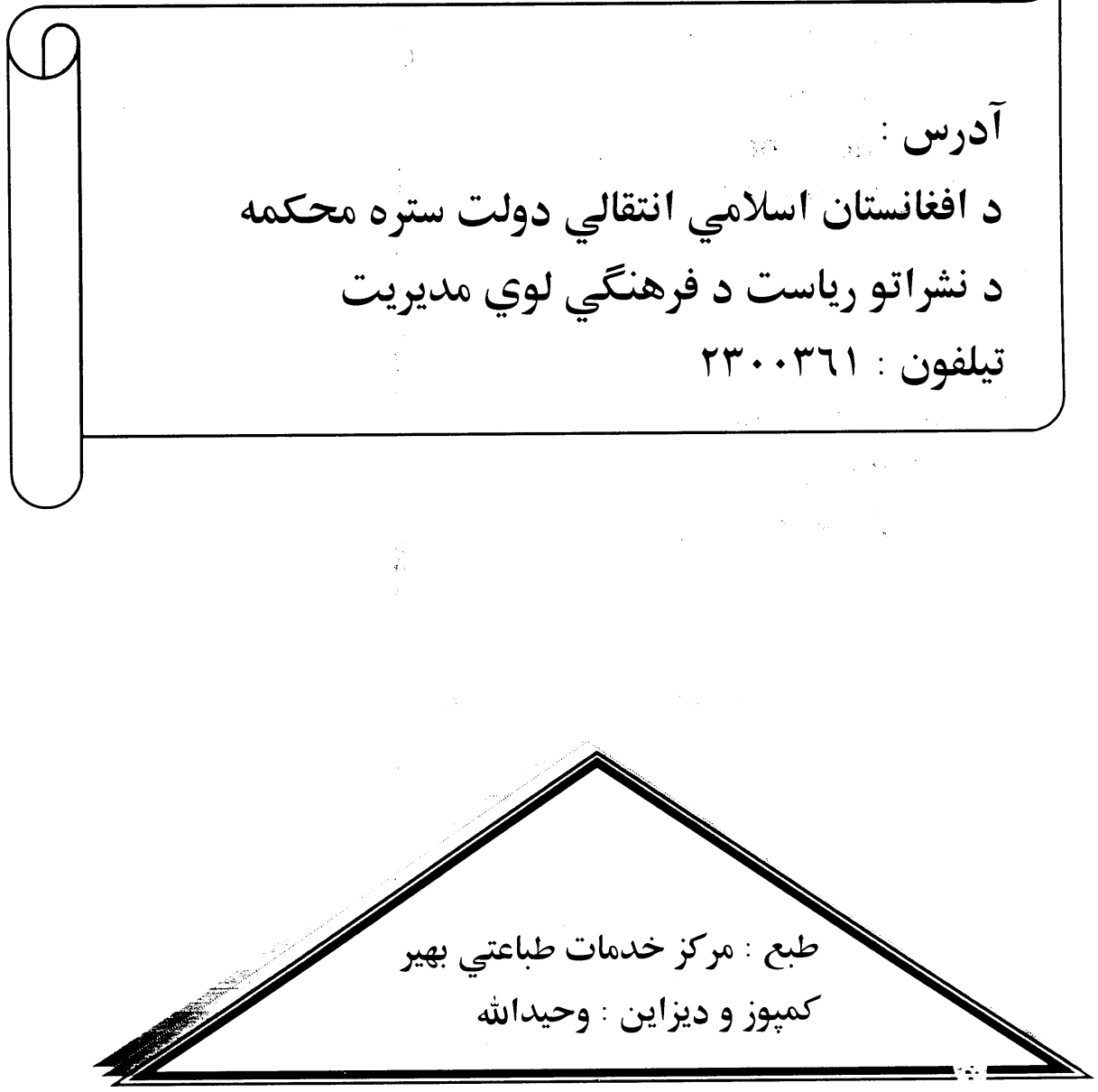


18

A35

260

Monthly journal

Published by:

The Supreme Court

of

The Islamic Transitional

Government of

Afghanistan

Under The Supervision of

The Editorial board

Address:

Department of publication

Supreme Court

Kabul - Afghanistan

7-8

October

November

2004 